This document was prepared in conjunction with work accomplished under Contract No. DE-AC09-96SR18500 with the U. S. Department of Energy.

\title{
DISCLAIMER
}

This report was prepared as an account of work sponsored by an agency of the United States Government. Neither the United States Government nor any agency thereof, nor any of their employees, nor any of their contractors, subcontractors or their employees, makes any warranty, express or implied, or assumes any legal liability or responsibility for the accuracy, completeness, or any third party's use or the results of such use of any information, apparatus, product, or process disclosed, or represents that its use would not infringe privately owned rights. Reference herein to any specific commercial product, process, or service by trade name, trademark, manufacturer, or otherwise, does not necessarily constitute or imply its endorsement, recommendation, or favoring by the United States Government or any agency thereof or its contractors or subcontractors. The views and opinions of authors expressed herein do not necessarily state or reflect those of the United States Government or any agency thereof. 


\section{High Level Waste System Impacts from Acid Dissolution of Sludge}

by

EDWARD KETUSKY

Westinghouse Savannah River Company

Savannah River Site

Aiken, South Carolina 29808

Additional Authors:

This paper was prepared in connection with work done under the above contract number with the U. S.

Department of Energy. By acceptance of this paper, the publisher and/or recipient acknowledges the U. S. Government's right to retain a nonexclusive, royalty-free license in and to any copyright covering this paper, along with the right to reproduce and to authorize others to reproduce all or part of the copyrighted paper. 
HIGH LEVEL WASTE SYSTEM IMPACTS

FROM ACID DISSOLUTION OF SLUDGE

by

EDWARD THOMAS KETUSKY

submitted in fulfilment of the requirements for

the degree of

MAGISTER OF TECHNOLOGIAE

in the subject

CHEMICAL ENGINEERING

at the

UNIVERSITY OF SOUTH AFRICA

SUPERVISOR: MRS F SAMADI

JOINT SUPERVISOR: DR W MEYER

APRIL 2006 


\author{
ABSTRACT \\ High Level Waste System Impacts \\ From Acid Dissolution of Sludge \\ by

\section{EDWARD T. KETUSKY}

This research evaluates the ability of $\mathrm{OLI}^{\odot}$ equilibrium based software to forecast Savannah River Site High Level Waste system impacts from oxalic acid dissolution of Tank 1-15 sludge heels.

Without further laboratory and field testing, only the use of oxalic acid can be considered plausible to support sludge heel dissolution on multiple tanks.

Using $\mathrm{OLI}^{\odot}$ and available test results, a dissolution model is constructed and validated. Material and energy balances, coupled with the model, identify potential safety concerns. Overpressurization and overheating are shown to be unlikely. Corrosion induced hydrogen could, however, overwhelm the tank ventilation. While $\mathrm{pH}$ adjustment can restore the minimal hydrogen generation, resultant precipitates will notably increase the sludge volume. $\mathrm{OLI}^{\circ}$ is used to develop a flowsheet such that additional sludge vitrification canisters and other negative system impacts are minimized. Sensitivity analyses are used to assess the processability impacts from variations in the sludge/quantities of acids. 
TABLE OF CONTENTS

ABSTRACT

1 PROBLEM AND NEED FOR SLUDGE HEEL DISSOLUTION ….................... 3

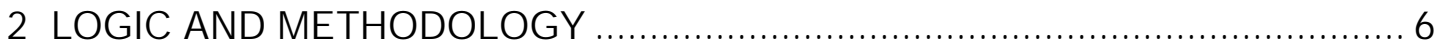

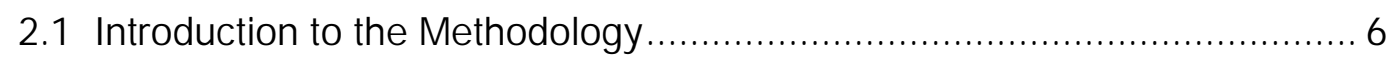

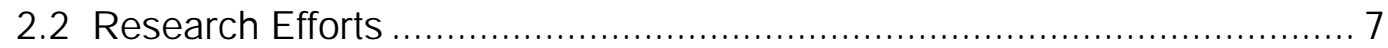

3 SLUDGE HEEL DISSOLUTION LITERATURE REVIEW ............................. 9

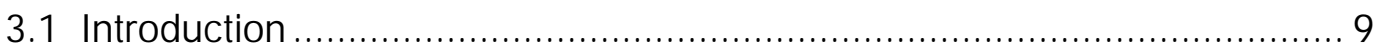

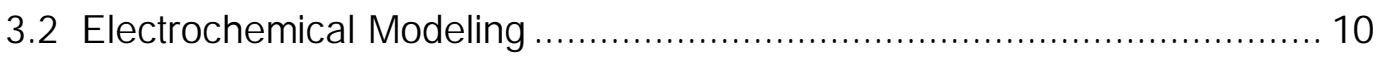

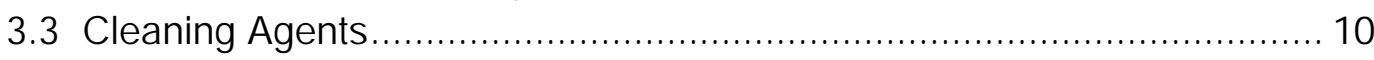

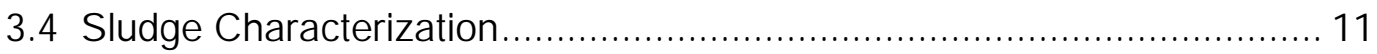

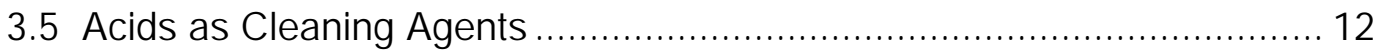

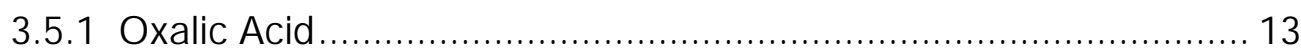

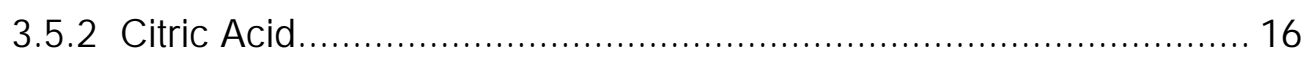

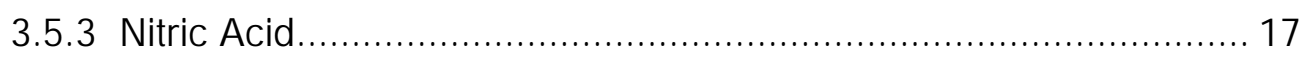

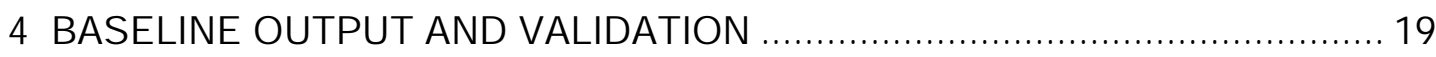

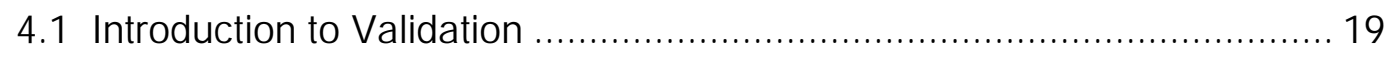

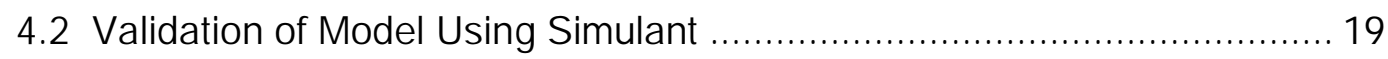

4.2.1 Measured Simulant Dissolutions ................................................. 20

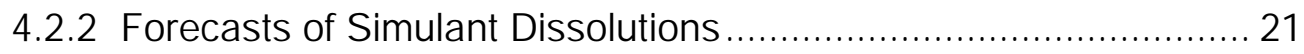

4.2.3 Forecast vs Measured Simulant Dissolutions .............................. 21

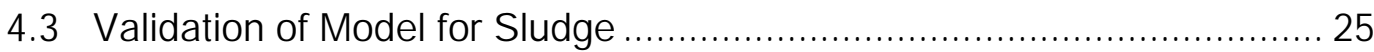

4.3.1 Measured Tank 8 Purex Sludge Dissolution ................................ 25

4.3.2 Forecast of Tank 8 Purex Sludge Dissolution .............................. 26

4.3.3 Forecast vs Measured Tank 8 Purex Dissolution............................ 26

4.3.4 Measured Tank 16 HM Sludge Dissolution................................. 27

4.3.5 Forecast of Tank 16H HM Sludge Dissolution .............................. 28

4.3.6 Forecast vs Measured Tank 16HM Sludge Dissolution .................. 28

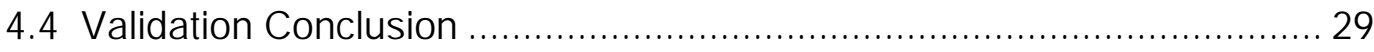




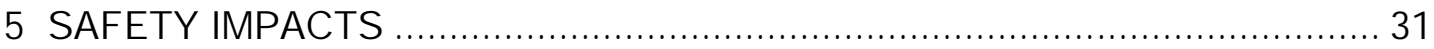

5.1 Introduction to Material Balance and Safety Impacts ............................. 31

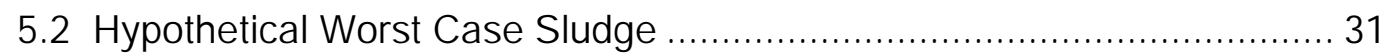

5.3 Supernate in Adjustment Tank ................................................................ 37

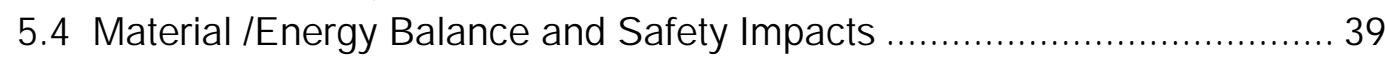

5.4.1 Hypothetical Worst Case Sludge Material Balance....................... 39

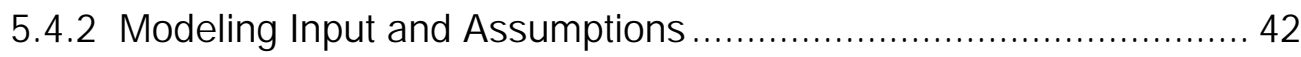

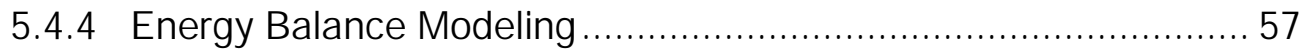

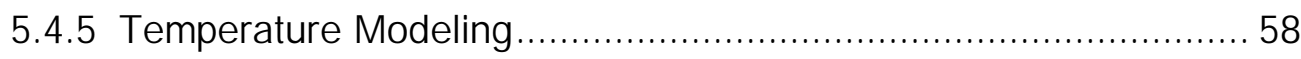

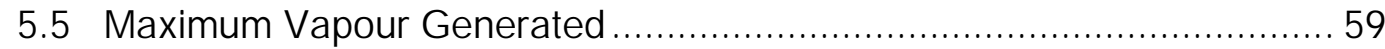

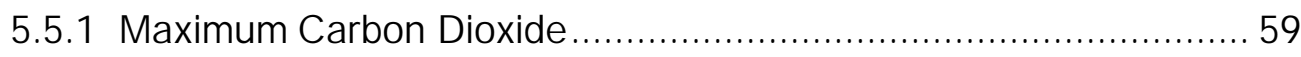

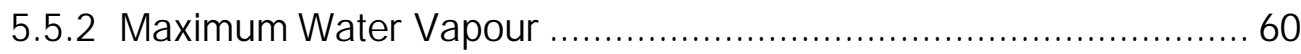

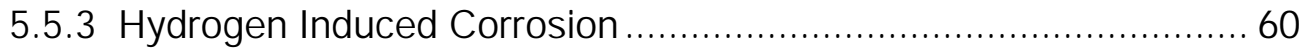

5.6 Conclusion on Material Balance and Safety Impacts ............................... 63

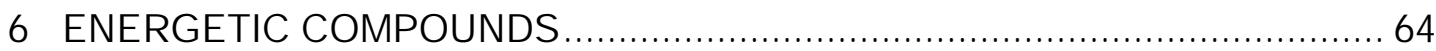

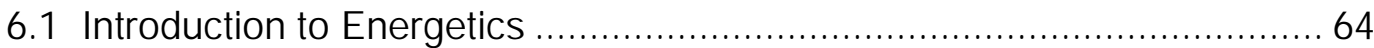

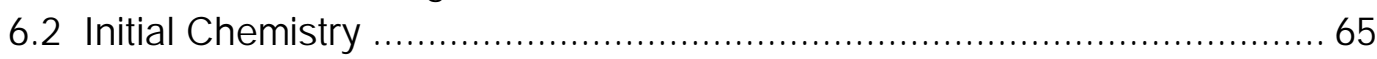

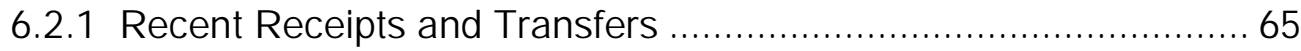

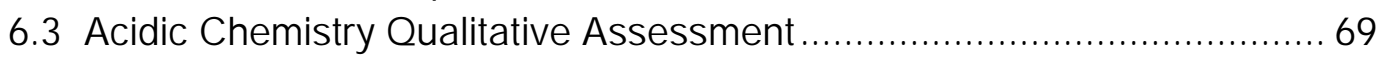

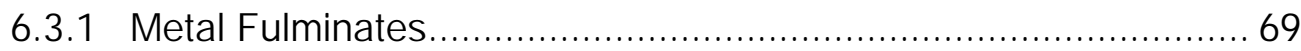

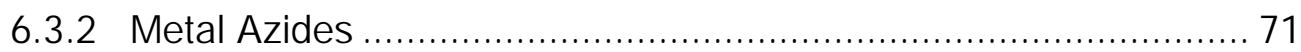

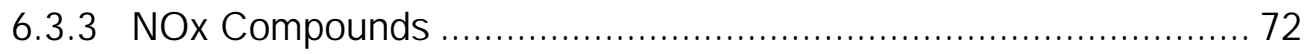

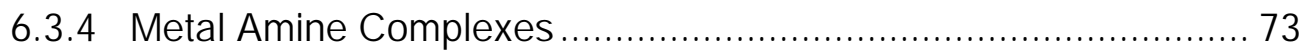

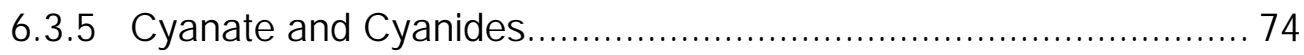

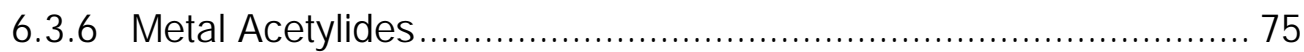

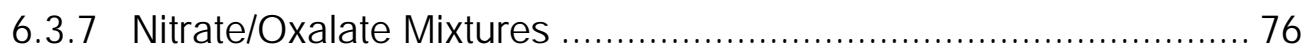

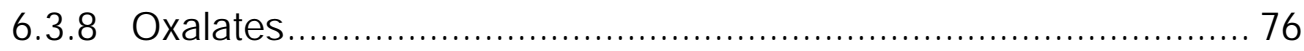

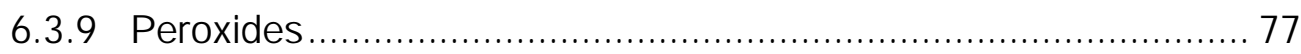

6.3.10 Halogens and Metal Halogenates ............................................. 79

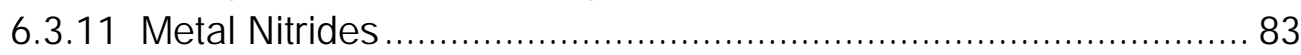

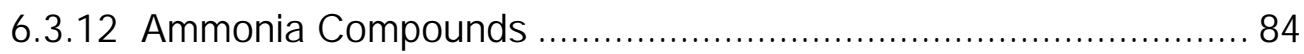

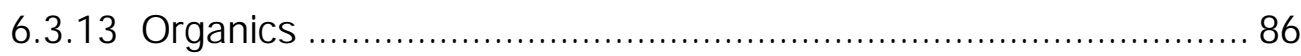

6.4 Conclusion on Energetic Compounds ................................................ 91 


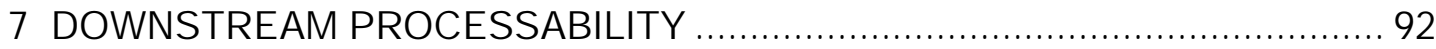

7.1 Introduction to Downstream Processability ........................................ 92

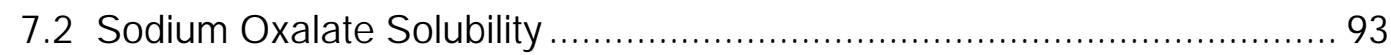

7.3 Sludge Heel Removal ........................................................................ 94

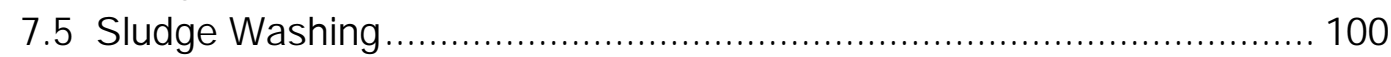

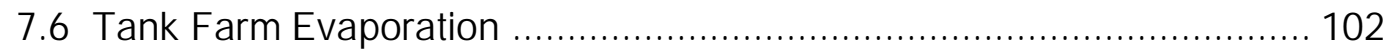

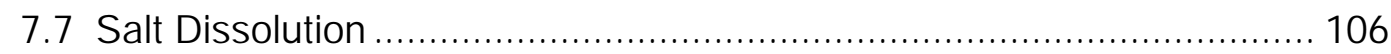

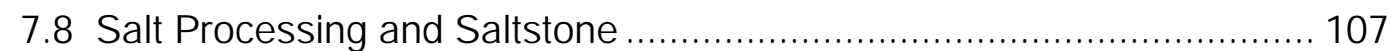

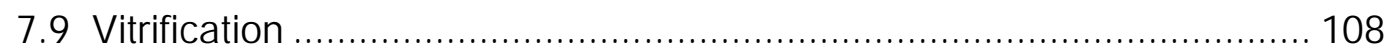

7.10 Effect on Waste Processing .......................................................... 110

7.10.1 Adjusted Supernate ……................................................... 110

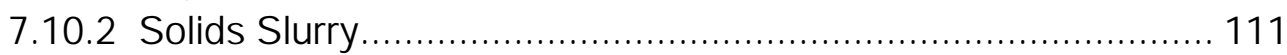

7.10.3 Recommended Process Flowsheet ...................................... 112

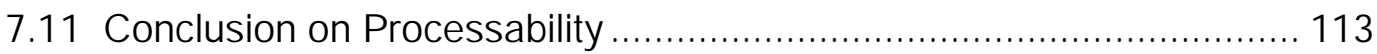

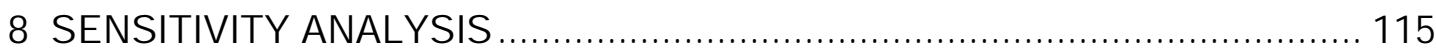

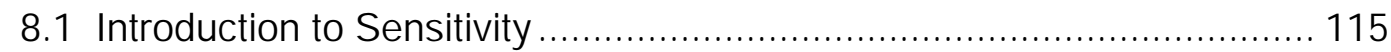

9 CONCLUSION

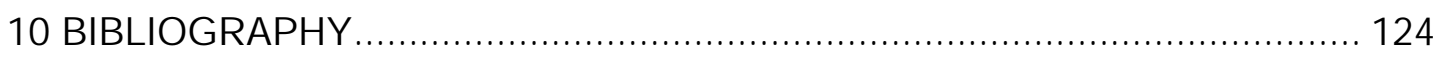

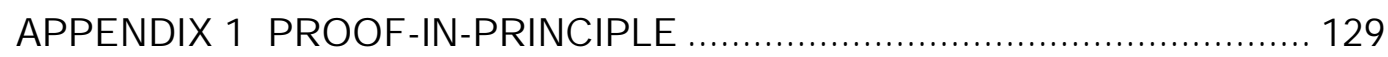

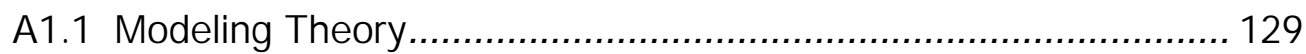

A1.2 Comparisons with Literature .............................................. 130

A1.3 Comparisons with Other S imulators ......................................... 133

APPENDIX 2 VALIDATION MISCELLANEOUS ..................................... 134

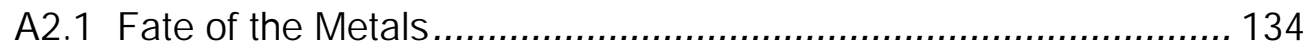

APPENDIX 3 SPIKED MATERIAL BALANCE ......................................... 136

APPENDIX 4 PROCESS MODELING SPECIFICS …........................... 140

A4.1 Heel Process Model Description ........................................... 140

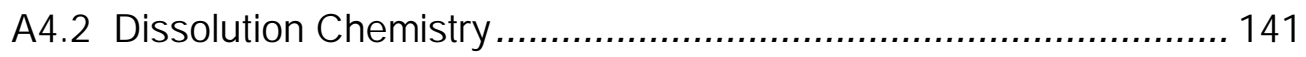

APPENDIX 5 DOWNSTREAM PROCESSING RESULTS …..................... 145

APPENDIX 6 HISTORICAL EXPERIENCE …....................................... 163 


\section{LIST OF FIGURES}

Figure 1-1 Oxalic Acid Sludge Heel Dissolution Process Sketch .....................4

Figure 3-1 Factors Determining Success for Sludge Dissolution.....................10

Figure 4-1 Forecast vs Measured Purex Sludge Simulant Dissolutions ............ 23

Figure 4-2 Forecast vs Measured HM Sludge Simulant Dissolution.................24

Figure 4-3 Forecast vs Measured Tank 8 Purex Sludge Heel Dissolution ........27

Figure 4-4 Forecast vs Measured Tank 16 HM Sludge Heel Dissolution ..........29

Figure 5-1 Treatment and Adjustment Tank Material Balance Diagram ............39

Figure 5-2 Print Screen for Hypothetical Worst Case Sludge...........................43

Figure 5-3 Input Screen for Recommended Amount of Acid for First Strike .....43

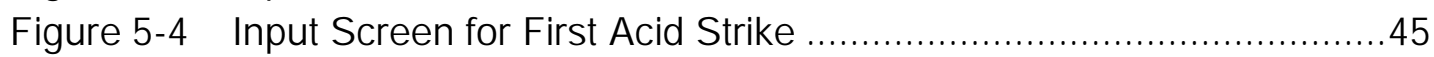

Figure 5-5 Screen for Solids After First Acid Strike ....................................47

Figure 5-6 Input Screen for Second Acid S trike ...........................................48

Figure 5-7 Input Screen for Third Acid S trike ...............................................50

Figure 5-8 Input Screen to ph Adjustment in Adjustment Tank ........................51

Figure 5-9 Input Screen of 1st Transfer of Spent Acid to the Adjustment Tank.54

Figure 5-10 Input Screen of 2nd Transfer of S pent Acid to the Adjustment Tank55

Figure 5-11 Input Screen of 3rd Transfer of Spent Acid to the Adjustment Tank 55

Figure 5-12 Input Screen of Maximum Carbon Dioxide.....................................59

Figure 5-13 Measured Corrosion Rates for Oxalic Acid Exposed Steel ............. 61

Figure 7-1 Sludge Heel Removal Process Diagram ......................................93

Figure 7-2 Oxalate Solubility Curve as a Function of Sodium ........................94

Figure 7-3 Oxalate from $\mathrm{pH}$ Adjusted Liquid Added to Feed Tank .................104

Figure 7-4 Oxalate from $\mathrm{pH}$ Adjusted Liquid Added to Drop Tank...................106

Figure 7-5 Recommended Heel Removal Flow Diagram ..............................112

Figure A3-1 Input Screen of Spiked Material Balance.................................... 136

Figure A4-1 Schematic of the Sludge Heel Dissolution Process .................... 140

Figure A5-1 Sludge Heel Dissolution Process Diagram ............................... 145 


\section{LIST OF TABLES}

page

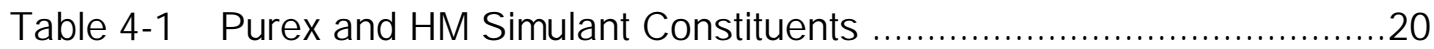

Table 4-2 Measured Purex and HM S imulant Dissolutions .............................20

Table 4-3 Forecast of Purex and HM Simulant Dissolutions ............................21

Table 4-4 Forecast vs Measured Purex and HM Simulant Dissolutions ............22

Table 4-5 Tank 8 Purex Sludge Constituents ..............................................25

Table 4-6 Measured Tank 8 Purex Sludge Dissolution ...................................26

Table 4-7 Forecast of Tank 8 P urex Sludge Dissolution ..................................26

Table 4-8 Forecast vs Measured Tank 8 Purex Sludge Dissolution..................26

Table 4-9 Tank 16 HM Sludge Constituents ................................................25

Table 4-10 Measured Tank 16 HM Sludge Dissolutions ..................................28

Table 4-11 Forecast of Tank 16 HM Sludge Dissolution ..................................28

Table 4-12 Forecast vs Measured Tank 16 HM Sludge Dissolution...................29

Table 4-13 Summary of Forecast vs Measured Dissolutions ..............................30

Table 5-1 Constituents Considered in Modeling .............................................34

Table 5-2 Range of Transfer Constituent Sludge Mass for Tanks 1-15.............35

Table 5-3 Normalized Maximum Sludge Mass ...............................................36

Table 5-4 Bounding Hypothetical Worst Case Sludge Heel .............................37

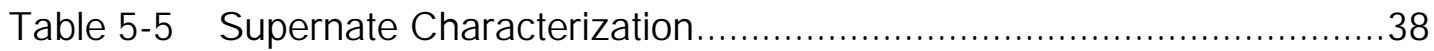

Table 5-6 Model Input for 5K Gallons of Bounding Supernate .........................38

Table 5-7 Output from the First Acid Strike ................................................46

Table 5-8 Output from the Second Acid Strike ................................................49

Table 5-9 Output from the Third Acid Strike ................................................50

Table 5-10 pH Adjustment with Supernate Add to Spent/Excess Acid ................52

Table 5-11 Combined Output in the Adjustment Tank....................................56

Table 5-12 Treatment Tank and Adjustment Tank Temperatures ......................58

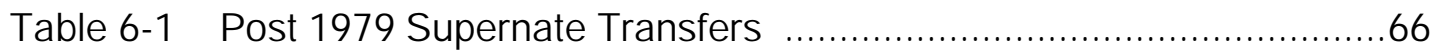

Table 6-2 Post 1979 Waste Receipts into Tanks 1-15 ..................................68

Table 6-3 Miscellaneous Organic \& Chemicals .............................................69

Table 6-4 Abundance of Nitrates/Nitrites During Acid Cleaning ........................70

Table 6-5 Properties of Peroxides …….....................................................79

Table 6-6 Estimated Chloride Abundance During Acid Cleaning ......................80

Table 6-7 Estimated lodine Abundance During Acid Cleaning ........................90

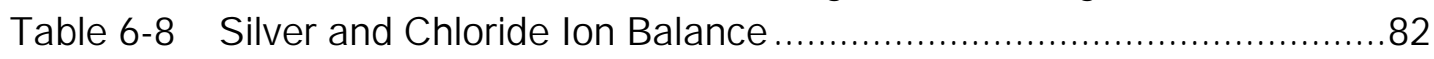

Table 6-9 Estimated Nitride Abundance During Acid Cleaning ….....................83 
Table 6-10 Partial Pressures of Ammonia (with $6.2[\mathrm{Na}$ ], $1.7[\mathrm{OH}]$ ) ....................85

Table 6-11 Properties of Hydrazine and Hydroxylamine (in Water)....................85

Table 6-12 Heat of Combustion/F ormation for Organics .................................87

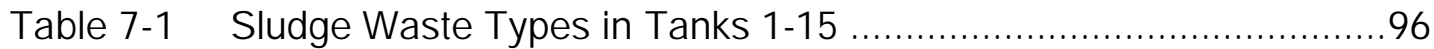

Table 7-2 Composition of Sludge Solids by Waste Type.................................96

Table 7-3 Estimated Composition of Sludge Solids in Tank Heels ..................97

Table 7-4 Estimated Composition of Sludge Slurry in Sludge Heels ................98

Table 7-5 Dissolution Material Balance Cases Considered (Case 1-4) ...........99

Table 7-6 Supernate Composition ............................................................100

Table 7-7 Sodium Oxalate Balance for Sludge Washing..............................102

Table 7-8 Evaporator Feed Tank Initial Composition ....................................104

Table 7-9 Sodium Oxalate Balance for the Evaporator .................................105

Table 7-10 Average Saltcake Composition ..................................................107

Table 7-11 Effect of Sodium Oxalate in Sludge Batch 3 at DWPF .................109

Table 8-1 Sensitivity of Dissolution to Purex Sludge Variations ....................116

Table 8-2 Sensitivity of Dissolution to HM Sludge Variations .........................117

Table 8-3 Solids in Purex Sludge Treatment Tank from Excess Oxalic Acid ..117

Table 8-4 Solids in HM Sludge Treatment Tank from Excess Oxalic Acid ......118

Table 8-5 Post pH Adjustment P recipitate/P urex Variations ..........................118

Table 8-6 Post pH Adjusted Precipitate/HM Variations .................................119

Table 8-7 Liquid \& Solid Increase from Purex Sludge Heel Dissolution ...........120

Table 8-8 Liquid and Solid Increase from Oxalic Acid Dissolution of HM .......120

Table A2-1 Fate of 4 Primary Metal Oxides in Purex Simulant Dissolution .......134 Table A2-2 Fate of 4 Primary Metal Oxides in HM Simulant Dissolution............135

Table A3-1 Fate of Organics and Energetic Materials ..................................137

Table A4-1 Oxalic Acid Reactions with Sludge Components ...........................142

Table A4-2 Oxalic Acid Needed to React with $1 \mathrm{~kg}$ of HM Sludge ....................143

Table A4-3 Oxalic Acid Needed to React with $1 \mathrm{~kg}$ of P urex Sludge.................143

Table A4-4 Oxalic Acid Needed to React with $1 \mathrm{~kg}$ of Tank 16 Sludge ..............144 
Table A5-1 Tank 8 Purex Dissolution Material Balance, pH Adj. w/ NaOH

Table A5-2 Tank 8 Purex Dissolution Material Balance, pH Adj. w/ Supernate..151 Table A5-3 Tank 11 HM Dissolution Material Balance, pH Adj. w/ NaOH .........155 Table A5-4 Tank 11 HM Dissolution Material Balance, pH Adj. w/ Supernate ...159

Table A6-1 Sequence of Events for Tank 16 Acid Cleaning.............................164

Table A6-2 Tank 16 Sludge Composition....................................................166

Table A6-3 Comparison of Tank 16 Forecast and Measured Results ................167 


\section{DECLARATION}

I declare that this thesis does not incorporate without acknowledgement any material previously submitted for a degree or diploma in any university, and that to the best of my knowledge it does not contain any materials previously published or written by another person except where due reference is made in the text. 


\section{ACKNOWLEDGMENTS}

I would like to thank my wife, Kim, who always seems willing to cheerfully proof read.

My mentors, Dr B Wiersma and Mr. E Freed, who, when difficulties arose, always seemed willing to listen and provide the necessary advice and direction.

My co-workers and colleagues, for letting me be inquisitive.

The support and staff at the University of South Africa who helped make the international administrative complexities and communicational differences seem almost non-existent.

Utmost admiration, respect, and thanks, however, belong to my University of South Africa supervisor and joint supervisor, Ms. F. Samadi and Dr W Myer. Without their diligence, hard work, and understanding, I would never have had this unique international opportunity. 


\section{PROBLEM AND NEED FOR SLUDGE HEEL DISSOLUTION}

At the Savannah River Site (SRS) near Aiken, South Carolina, there are approximately 36 million gallons of legacy, cold war generated, highly radioactive, alkaline High Level Wastes (HLW) [Barnes, 2003:6]. The approximately 46 tanks that hold the waste are fabricated from mostly commercially available ASTM-285B carbon steel [Sunrammanian, 2005:1]. Out of those 46 tanks, Tanks 1-15 are single containment, non-conforming tanks built mostly in the 1950's. Some of these tanks contain sludge heels which need to be removed as part of closure and/or as feed for vitrification [Badheka, 2003].

Since many of the tanks were built in the 1950's and are being used past their original design life, significant sludge removal and processing campaigns are scheduled. In order to process the sludge; however, it must be removed from the tanks. Currently, slurry pumps mechanically remove the sludge with only varying degrees of success. To aid in the removal, the use of oxalic acid for sludge dissolution is being considered [Federal Register, 2002:53784-53787 ].

Because of the unique process complexities, as well as concern about chemical incompatibilities, only limited acid dissolution has been performed on solids within the process. The last significant solids dissolution was performed as an in-situ cleaning of an evaporator pot. Since there were significant concerns about adding acid directly to the process, an $\mathrm{OLI}^{\circ}$ based chemical equilibrium model was used to better understand the sodium aluminosilicate-acid interactions. The use of the model proved very successful [Barnes, 2003]. Additionally, both Hanford [Saito, 2002) and SRS [Pike, 2002], the two largest U.S. repositories of alkaline High Level Waste, used $\mathrm{OLI}{ }^{\circ}$ based chemical equilibrium models to help forecast salt dissolution. This research, therefore, investigates the use of OLI Environmental Simulation Program $(E S P)^{\odot}$ and $\mathrm{OLI}$ Stream Analyzer ${ }^{\odot}$ to help understand and forecast dissolution effectiveness and potential system and process impacts associated with sludge dissolution within HLW. 
Dissolution of sludge heels using acid treatment of multiple SRS HLW tanks is being planned. Figure 1-1 shows the sludge dissolution process diagram as an overview and provides insight to the complexity and scope of potential system impacts.

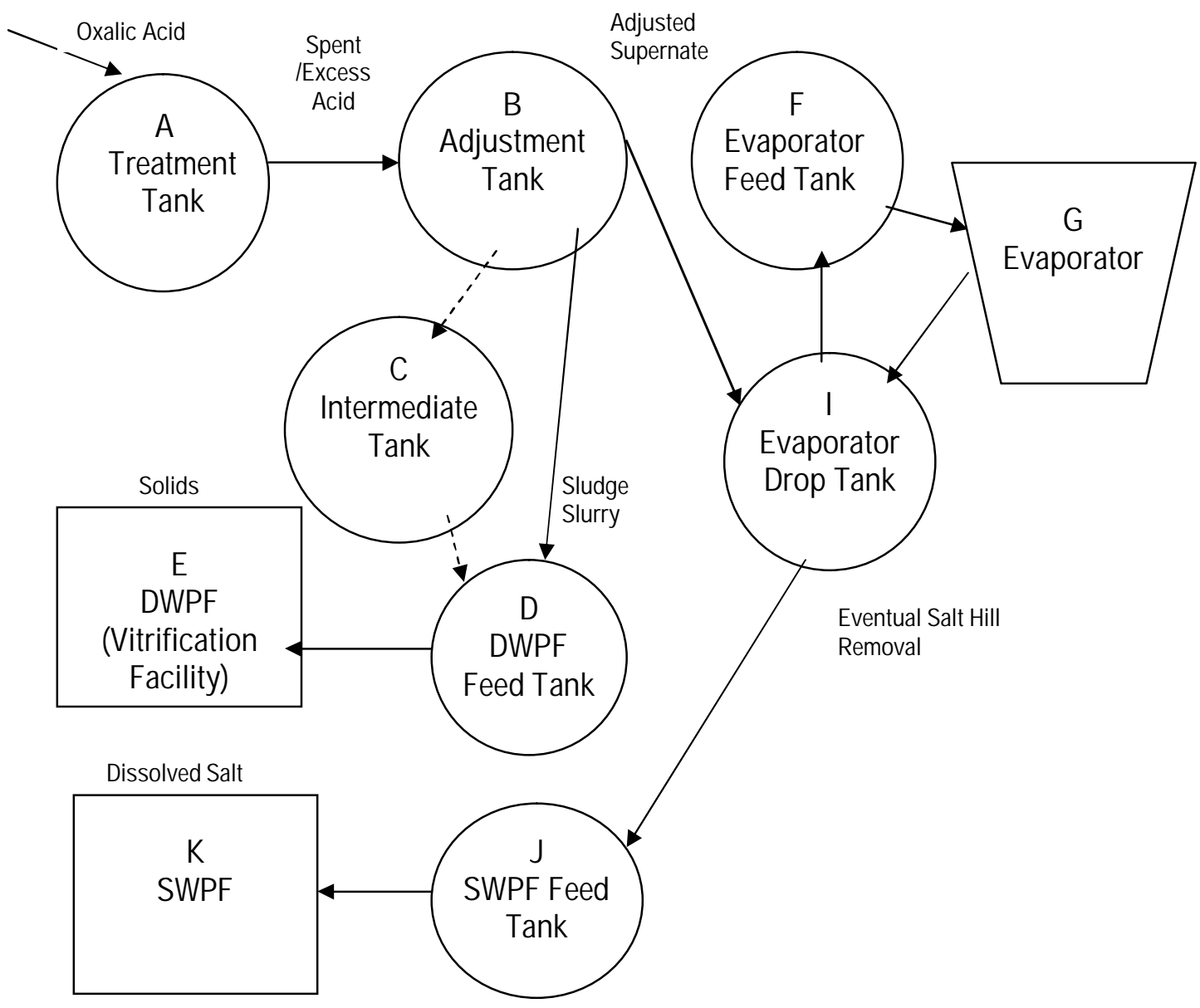

Figure 1-1 Oxalic Acid Sludge Heel Dissolution Process Sketch

Where:

$A=$ Approximately 1 million gallon treatment tank

$\mathrm{B}=$ Approximately 1 million gallon $(\mathrm{pH})$ adjustment tank

$\mathrm{C}=$ Intermediate tank, if necessary, to support the vitrification schedule

$\mathrm{D}=$ Defense waste processing facility (DWPF) feed tank, as it is used to wash sludge prior to feed to DWPF (i.e., vitrification)

$E=D W P F$. Place where High Level Waste (HLW) sludge is vitrified in canisters to be transported for eventual disposal

$\mathrm{F}=\mathrm{E}$ vaporator feed tank

$\mathrm{G}=$ Evaporator 
$\mathrm{I}=$ Evaporator drop tank

$\mathrm{J}=$ Salt waste processing facility (SWPF) feed tank

$\mathrm{K}=\mathrm{SWPF}$ is the place where supernate and dissolved salt are currently planned to be disposed, beginning in the near future

Since the HLW system is a complex process as shown above in Figure 1-1, it is necessary to understand the effects that the acid additions and the subsequent return of $\mathrm{pH}$, such to minimize corrosion, will have on the tank farm and on the entire HLW process. Originally, nitric acid, citric acid, and oxalic acid were identified as potential candidates to aid in the sludge removal [Hobbs, 2004]. For Tanks 1-15, the considerations of nitric and citric acid were eliminated. Neither is as effective as a tank cleaning agent [Adu-Wusu, 2003:23]. Nitric acid will cause flammable gas generation issues, and citric acid will preferentially dissolve the uranium, causing potential downstream processing concerns during vitrification [Adu-Wusu, 2003:70]. The model and evaluation efforts for Tanks 1-15, as contained in this report, therefore, after the initial literature review, solely focus on the use of oxalic acid.

Besides the effectiveness in dissolving sludge, the system impacts considered are: 1) corrosion, 2) process/waste stream acceptance and 3) overheating, overpressurization, and, flammability. 


\section{LOGIC AND METHODOLOGY}

\subsection{Introduction to the Methodology}

The subject and scope of this research was chosen to ensure applicability, and to ensure that the outcome will provide significant, yet practical value to the SRS sludge heel removal effort. Because acid dissolution represents what can be considered a new technology, many parameters were not yet identified or formally documented at the initiation of this effort.

\subsection{Research Approach/Design}

The research design was originally based on extending the applicable acid dissolution sample data in terms of sensitivity and variability analyses. Available $\mathrm{OLI}^{\circledR}$ software would be used, as it allows new chemistries to be quickly estimated. The goal of the research was to determine if acid solutions could be used to effectively aid in sludge heel dissolution without:

1) significantly increasing tank corrosion.

2) creating gas/flammability process hazards.

3) creating non-disposable process waste streams.

Sensitivity and Variability Analyses (SVAs) were planned to be used to determine acceptability of dissolution, flammability, corrosion, and processability for nitric/oxalic/citric acid solutions. Early on, however, it was determined that both the use of nitric and citric acid could not be currently supported, and research would be limited to the use of oxalic acid. Additionally, SVAs could not be formally used as originally planned because "acceptability" for parameters being evaluated seemed poorly defined.

In hindsight, there was a fundamental problem with the SVA approach. SVAs could only be determined if the acceptability was quantitatively based. Instead, almost all of the safety and processability evaluations were deterministically based. To meet the intent of the research, therefore, instead of building SVAs into each aspect of the evaluation, sensitivity analyses limited to dissolution and precipitation are developed only after all other evaluations are complete. 
In summary, as part of the research, the following are performed:

1) The model's ability to forecast dissolution effectiveness is evaluated.

2) Overpressurization, overheating, and flammability are evaluated and the effect of oxalic acid dissolution on organics and energetic materials is evaluated.

3) Based on process impacts, a preferred flowpath is determined.

4) A simplified sensitivity analysis, which more or less is limited to determining the amount of precipitation, is also developed.

In addition, only after all other evaluations are complete, limited sensitivity analyses are developed for dissolution/precipitation.

\section{3 Research Efforts}

As part of this research the following endeavors are performed:

- A comprehensive literature search is initiated.

- A model for the purpose of determining dissolution effectiveness is built using the Savannah River National Laboratory (SRNL) recipe for Purex sludge simulant and H-Area Modified Process (HM) sludge simulant [Hobbs, 2004:11-12].

- To validate the model's ability to estimate total wt $\%$ of sludge dissolved, initial model dissolution forecasts for simulant are compared to the SRNL measured total wt\% of simulant dissolved.

- To further validate the model, forecasts for Purex sludge and HM sludge are compared to SRNL measured sludge dissolution.

- A material balance is constructed across the (sludge) treatment tank and $(\mathrm{pH})$ adjustment tank conservatively evaluating gas generation/flammability and other possible safety impacts. 
- The material balance is conservatively revised as necessary using "spiking of energetics" to understand the impact of using oxalic acid on energetic materials and organics within the tank farm.

- An integrated flowsheet is built with the impacts to downstream processability/waste stream acceptance evaluated.

- In addition, only after all other evaluations are complete, limited sensitivity analyses are developed for dissolution/precipitation. 


\section{SLUDGE HEEL DISSOLUTION LITERATURE REVIEW}

\subsection{Introduction}

Initially, as part of writing the research proposal, many experts were consulted to determine if the modeling of sludge dissolution with acid seemed to represent something that would have useful utility. The authorities consulted include Savannah River Site (SRS) Tank Farm Engineering, SRS Liquid Waste Chemical Engineering, Planning Integration and Technology, and Savannah River National Laboratory (SRNL) scientists, scientists and chemists from other U.S. National Laboratories, and academia. Through these efforts, a significant amount of information was gathered.

The comprehensive literature search was conducted, considering basic chemical theory such as aqueous chemistry [Morel, 1983] electrochemical theory, basic chemical reactions [Metcalf, 1978], general acid cleaning [Wiersma, 2004], acid induced corrosion effects of acid on energetic compounds [Ketusky, 2003], and flammable gas formation reactions [Hobbs, 1999] were also used. A large part of the effort also consisted of SRS specific documents such as: High Level Waste characterization database [HLW, 2005]; HLW process records (i.e., acid treatments of iron, aluminum and sludge compounds affecting high level waste tanks) [Cavin, 2003]; and historical files from SRS HLW in-tank sludge dissolution efforts [Bradley, 1977; J ohnson, 1987; West, 1980]. Similar efforts were performed the Hanford Site and West Valley and were also investigated [Elmore, 1996; Fluor, 2003; Huckaby, 2004; Gray, 1995].

The literature review shows that, at a minimum, dissolution can be affected by four major attributes [Adu-Wusu, 2003:25]. For the purpose of this effort, they are referred to as rheology, chemistry, energy, and cleaning solution. This is illustrated in Figure 3-1. 


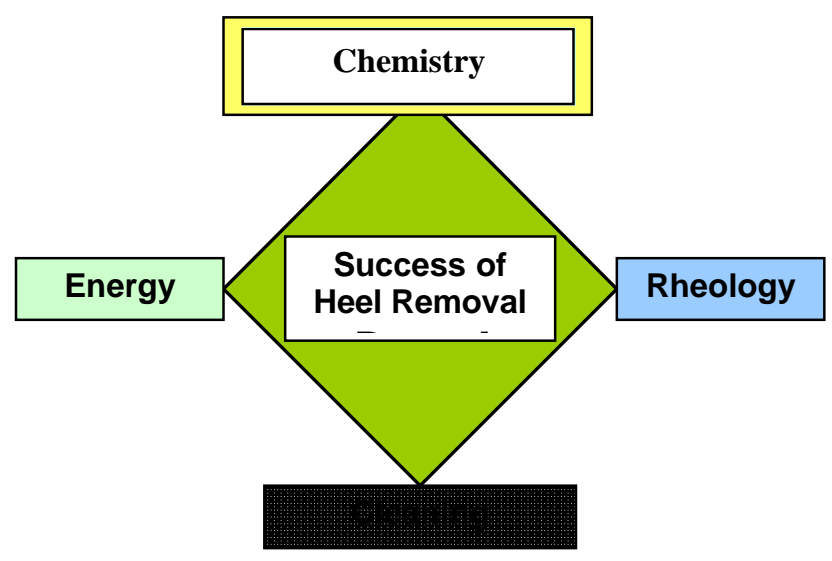

Figure 3-1 Factors Determining Sludge Heel Removal Success

Since the possible energy and rheology are indeterminate, as the pumps are mostly yet to be installed, and the rheology is poorly known, most of the initial literature review focuses on different solutions and energy.

\subsection{Electrochemical Modeling}

Literature supplies the bulk of the theory. The literature reviewed shows that electrochemical modeling is extremely complex and hard to forecast in real process systems. Often the reactions behave in complex and seemingly counter-intuitive ways, introducing great risk if misapplied [Anderko, 2002:3].

\subsection{Cleaning Agents}

The current understanding of the chemical composition of heels includes the possibilities of aluminosilicate such as cancrinite and sodalite, hematite and boehmite [Adu-Wusu, 2003:26-30]. The exact chemical composition of the sludge varies from tank to tank, and even within the tank. The chemical cleaning efficiency largely depends on the cleaning agent and the type of oxide. HLW sludge is an aggregate of the different oxides. The sludge, almost assuredly, will behave differently from the known pure oxide components. This is due, in part, to the often trace contents with the oxides, and the presence of other trace elements in solution that interferes with dissolution. 
There are generally four types of chemical cleaning processes (surface controlled dissolution) by which inorganic oxides and hydroxides dissolve. They are as follows:

- $\quad$ Reductive agents (e.g., sodium thiosulfite)

- $\quad$ Oxidative agents (e.g., hydrogen peroxide)

- Hydrogen ion assisted dissolution with acids (e.g., nitric acid)

- $\quad$ Ligands and complexing agents (e.g., organic acids like citric acid and oxalic acid)

The dissolution efficiency largely depends on the type of oxide or hydroxide compound it encounters. A general rule for dissolution is "the farther an oxide is from a hydrated form, the longer it takes it to dissolve." [Adu-Wusu, 2003:26] For example, $\mathrm{Mn}(\mathrm{OH})_{2}$ converts to $\mathrm{MnC}_{2} \mathrm{O}_{4}$ and $\mathrm{MnC}_{2} \mathrm{O}_{4} .2 \mathrm{H}_{2} \mathrm{O}$ prior to the bulk dissolving. Logically, each additional step adds additional uncertainty to the dissolution kinetics.

\subsection{Sludge Characterization}

There is limited characterization data based on actual samples of the sludge. Additionally, even if the tanks have slurrying capabilities, they may not be adequately mixed during sampling. Many times the sludge sample results appear to contradict the process history; [Cavin,2003:5] therefore, to ensure conservatism, characterization data is used. Although largely based on the process database, the characterization data are refined within the multiple aspects of the modeling and flowsheet. Examples within this effort include the use of the process database for bulk solids [HLW], while organics are based on spiking in excess of bounding sample results. Generally, laboratory simulant characterization data is preferred during the initial stages of model validation, because the constituents should be well known. However, when determining the potential system and downstream impacts, the process database is preferred because it enables bounding and realistic assessments to be developed .

The SRNL dissolution efforts report [Hobbs, 2004] is most valuable because it focuses on the development of recipes for sludge simulants and the subsequent 
laboratory dissolution using oxalic acid. The use of such simulants in the laboratory helps ensure that the sludge is well characterized. Excluding any analytical uncertainty, the difference between the laboratory results and the model forecasts, are likely caused by the inaccuracies in the model, and not by inaccurate characterization. The SRNL measured dissolution results report [Hobbs, 2004) details the making and results of laboratory dissolution of simulants and the dissolution of select HLW sludge.

The material balance across the treatment and $\mathrm{pH}$ adjustment tank [Badheka] supplies the primary input for the characterization using a hypothetical worst case sludge (i.e., HWCS). HWCS is defined as hypothetical sludge where constituent concentrations are maximized so that the most negative safety and processability conditions occur. Possible safety impacts include excessive hydrogen generation from corrosion, heat generation, and overpressurization.

The sludge and supernate characterizations are obtained from the process database as maintained in the waste characterization system [HLW, 2005:SLUDGE]. It represents the likely contents of the SRS HLW tanks 1-15, as modeled and considered in this effort.

\subsection{Acids as Cleaning Agents}

Although some laboratory testing of acid as a cleaning agent for actual HLW sludge has occurred, most of the research for using nitric/citric/oxalic acid used a simulant for the sludge. Out of the nitric, citric and oxalic acids, oxalic has been most often used on in-tank HLW sludge. One time, oxalic acid was used in the 1970's on intank SRS sludge, and once during 2003 at the United States Department of Energy Hanford Site [Fluor, 2003]. Overall, oxalic acid is the most researched cleaning agent for use on applicable HLW tank sludge. 


\subsubsection{Oxalic Acid}

Oxalic acid has been widely tested and utilized as a sludge dissolution/cleaning agent at SRS and other US Department of Energy facilities. Its use is backed by the largest body of literature [Adu-Wusu, 2003:6].

In literature, Poirier and Fink [Poirer, 2002] conduct a series of tests at SRNL investigating various cleaning agents for porous metal filters considered to be exposed to SRS HLW sludge. The testing showed that $4 \mathrm{wt} \%$ oxalic acid in a 60:1 volume ratio to both Purex and HM sludge was considered acceptable for cleaning the filters. This is important since the results of the testing showed that one cleaning solution could potentially be used for the dissolution of both HM and Purex sludge. Poirer also clearly shows the following:

- Increased oxalic acid enhances sludge cleaning/dissolution.

- Increasing the concentration, temperature, and contact significantly increases the amount of sludge dissolved, including aluminum, dissolved, over a given period.

In the late 1970's, Tank 16H, containing mostly small quantities of HM sludge from various other tanks, was used for an oxalic acid sludge dissolution demonstration. Prior to the demonstration, various laboratory testing was performed. Bradley and Hill [1977] report on the three sets of tests conducted in the late 1970's in support of oxalic acid sludge heel dissolution in Tank $16 \mathrm{H}$. They are as follows:

1) Scoping tests in laboratory with actual Tank $16 \mathrm{H}$ sludge

2) Short term laboratory tests of oxalic acid with simulated aluminum hydroxide, iron hydroxide, and manganese dioxide

3) Long term laboratory tests with Tank $16 \mathrm{H}$ sludge.

Laboratory Scoping Tests with SRS Tank 16 Sludge- Bradley [1977:6-15] details the laboratory testing, mixing about $2 \mathrm{ml}$ of SRS Tank $16 \mathrm{H}$ sludge with various cleaning agents (20 wt\% glycolic, 20 wt\% formic acid, 6 wt\% sulfamic acid, 6 wt $\%$ citric acid, 5 
$w t \%$ and $10 w t \%$ sulfuric acid, and $8 w t \%$ oxalic acid) at ambient temperature for 30 minutes with agitation. The test results concluded that oxalic acid/citric acid mixes and oxalic acid had the same relative effectiveness in dissolving Tank 16 sludge.

Short Term Laboratory Tests with Simulated Sludge Materials- B radley [1977:15-21] also shows that short-term laboratory tests of aluminum hydroxide, ferric hydroxide, and manganese dioxide were prepared and subjected to dissolution with oxalic acid. The tests varied the volume ratio of acid to sludge (10:1, 20:1, and 40:1) and the acid concentration ( $4 \mathrm{wt} \%$ and $8 \mathrm{wt} \%$ ). All of the tests were conducted at $55^{\circ} \mathrm{C}$. The following conclusions are drawn from the tests:

- $\quad 8 w t \%$ oxalic acid in a $20: 1$ volume ratio to aluminum hydroxide is required for complete dissolution

- $\quad 8$ wt\% oxalic acid in a 40:1 volume ratio to ferric hydroxide is required for complete dissolution

- $8 \mathrm{wt} \%$ oxalic acid in a 10:1 volume ratio to ferric hydroxide yields nearly $70 \%$ dissolution

- 8 wt\% oxalic acid in a 40:1 volume ratio to manganese dioxide results in a significant amount of dissolution

The shortfall of these tests is that they were performed on only one metal oxide or hydroxide at a time.

Long Term Laboratory Contact Tests with Actual Tank 16H Sludge- West [1980] shows that tests were conducted with oxalic acid using Tank $16 \mathrm{H}$ sludge to examine the dissolution efficiency. Multiple step experiments with final oxalic acid to sludge volume ratios as high as 80:1 with contact times of about 1 week are conducted. Results showed that two successive strikes, using $8 \mathrm{wt} \%$ oxalic acid, and an acid to sludge volume ratio of $40: 1$, dissolved over 96 vol\% of the Tank 16 sludge. Increased volumes of acid, however, did not result in additional dissolution.

It is difficult to compare the data between the tests because the experimental conditions were different. In addition, the specific sludge compounds were not given in Poirier and Fink's study [2003]. 
An apparent contradiction exists with the dissolution of manganese. Poirier and Fink concluded that manganese readily dissolved, while Bradley and Hill concluded that it was very difficult to dissolve. Both sets of tests, however, generally agree that $8 w t \%$ oxalic acid solutions in a 20:1 volume ratio with sludge will dissolve about 70 vol\% of sludge for up to three strikes with acid. After the third strike, the overall dissolution efficiency for the acid will drastically decrease.

Historic reports by Johnson [1987] and West [1980] detail the results of the oxalic acid treatment on the SRS HLW Tank 16 sludge heel. The effort included two water washes, three oxalic acid washes, and a final water rinse. The effort removed $99.9 \%$ of the radioactive waste from the tank. The in-tank full-scale demonstration corroborates the results of long-term tests using actual Tank 16 waste sludge.

The major difference between the in-field demonstration and modeling/testing, is that modeling uses higher concentrations of oxalic acid (i.e., generally 4 to 8 wt\%) compared to the (1 wt\%) used in the SRS Tank 16 demonstration.

Laboratory Testing at Hanford- Laboratory tests were performed for the Hanford site using oxalic acid and simulant and actual Hanford site tank 241-C-106 sludge [Fluor, 2003; Huckaby, 2004]. The tests were done using $10 \mathrm{wt} \%$ oxalic acid. The results of the testing were used as a form of validating the SRS laboratory results with 8 wt\% oxalic acid solution.

In the Hanford testing, even with increasing dissolution of the iron, aluminum, and manganese, the volume of sludge did not significantly change. In the testing, this was speculated to be the result of substitution of oxalate for oxide/hydroxide in the solids. That is, the overall weight did not change even with decreasing volume, because oxalate weighs more than oxide/hydroxide. Nearly all of the gas produced in the Hanford testing was $\mathrm{CO}_{2}$, with traces of $\mathrm{H}_{2}$ and $\mathrm{CH}_{4}$.

The Hanford testing also showed that restoring the $\mathrm{pH}$ of the spent oxalic acid/excess acid with HLW supernate and a $50 \mathrm{wt} \% \mathrm{NaOH}$ solution produces large 
volumes of easily compacted sodium oxalate. Although large volumes of sludge may be generated, this is important since it suggests that newly formed precipitating sodium oxalate may be easy to pump out of a tank, while aged sodium oxalate may be compacted and therefore more difficult to remove.

Corrosion of Carbon Steel from Oxalic Acid - As detailed below, acid concentration, carbon content of the metal, temperature and length of exposure greatly influence corrosion rates. The following testing was investigated.

Ondrejcin's [1976] corrosion testing was based largely on coupon tests that provided part of the technical basis for the chemical cleaning of Tank $16 \mathrm{H}$. Wilde's data [1984] is from coupon tests supporting the cleaning of SRS heat exchangers. Russian and SRNL tests were also used to investigate the effectiveness of acid cleaning on HLW sludge [Hobbs, 2004] [Adu-Wusu, 2003:15-42]. Additional literature was also obtained from studies performed at Pacific Northwest National Laboratory that supported the clean out of HLW tanks at West Valley [Gray, 1995].

All tests show that the rate for the general corrosion would be significantly less than $60 \mathrm{mil} / \mathrm{year}$ [Wiersma, 2004:23]. Additionally, data shows that temperature has a strong effect on the corrosion rate.

\subsubsection{Citric Acid}

The use of citric acid as a sludge dissolution agent was studied in detail during earlier efforts. Bradley and Hill [1977:30\&61] consider citric acid in Tank 16H sludge. They determined that citric acid, as a lone cleaning agent, is slightly less effective than oxalic acid. Additionally, comparison tests with simulated Tank $40 \mathrm{H}$ sludge and $0.5 \mathrm{M}$ citric acid at ambient temperatures and high volume ratios of acid solution to sludge (i.e., greater than 60:1), show that citric acid alone is less effective than oxalic acid [Poirer, 2002:14].

The bulk of information, on citric acid and oxalic/citric acid mixes, however, comes from recent tests performed by the V. G. Khlopin Radium Institute Mining Chemical Combine (MCC) and SRNL [Adu-Wusu, 2003: p55-61]. Both groups, working 
together, conducted tests with simulated Purex and simulated HM sludge. Results from the two teams varied, even though the MCC scientists used simulant sludge recipes provided by SRNL. The conclusions from the testing are as follows:

- Use of citric acid did not promote uniform dissolution of neutron poisons in relation to fissile products.

- Citric acid and citric acid/oxalic acid mixtures are only about as effective in dissolving sludge as oxalic acid.

Since the use of citric acid would require further processing, as it is not compatible with DWPF [Hobbs, 2004:27] and potentially only as effective as oxalic acid, the use of citric acid and oxalic/citric acid mixes were eliminated from further consideration.

\subsubsection{Nitric Acid}

The use of nitric acid is widely used for cleaning metal surfaces at SRS. The nitric acid corrosion mechanism has been studied for many years [Adu-Wusu, 2003:36\& 64]. For both sludge and simulants, it has been shown that $4 \mathrm{M}$ nitric acid performs comparably to only 4 wt\% oxalic acid, while the ideal strength for oxalic acid, as discussed above is $8 w t \%$.

Tests, [Hobbs, 2004:8-10] which involved placing $300 \mathrm{~mL}$ of simulated Tank 40 sludge and $60 \mathrm{~mL}$ of actual Tank 8 sludge in a beaker, were done, while adding 0.5 $\mathrm{M}, 1 \mathrm{M}, 2 \mathrm{M}$, and $4 \mathrm{M}$ nitric acid for a contact time of 1 and 8 hours in a single strike with an acid the sludge volume ratio of 5:1. Although the anodic reaction is simple, for iron to be oxidized to ferrous cation $\left(\mathrm{Fe}^{+2}\right)$, there are a number of cathodic reactions that must occur. The cathodic reduction of nitric acid likely progresses as shown by Reactions 3-1 through 3-4 [Adu-Wusu, 2003:59].

$$
\begin{aligned}
& \mathrm{H}^{+}+\mathrm{e}^{-}=\mathrm{H} \\
& \mathrm{HNO}_{3}+\mathrm{H}^{+}+\mathrm{e}^{-}=\mathrm{NO}_{2}+\mathrm{H}_{2} \mathrm{O} \\
& \mathrm{NO}_{2}+\mathrm{e}^{-}=\mathrm{NO}_{2}^{-}
\end{aligned}
$$




$$
\mathrm{H}^{+}+\mathrm{NO}_{2}^{-}=\mathrm{HNO}^{2}
$$

These equations make obvious the possibility of $\mathrm{NO}_{x}$ and ammonia issues associated with the use of nitric acid. The nitrous acid $\left(\mathrm{HNO}_{2}\right)$ that is formed, as shown above, regenerates $\mathrm{NO}_{2}$ by an interaction with the nitric acid as shown in Reaction 3-5 [Adu-Wusu, 2003:59].

$$
\mathrm{HNO}_{2}+\mathrm{HNO}_{3}=2 \mathrm{NO}_{2}+\mathrm{H}_{2} \mathrm{O}
$$

Ammonia salts are also formed. The ammonia salts decompose to form $\mathrm{N}_{2}$ and $\mathrm{NO}_{x}$ compounds by Reaction 3-6 and Reaction 3-7 [Adu-Wusu, 2003:59].

$$
\begin{aligned}
& \mathrm{NH}_{4} \mathrm{NO}_{2}=\mathrm{N}_{2}+2 \mathrm{H}_{2} \mathrm{O} \\
& \mathrm{NH}_{4} \mathrm{NO}_{3}=\mathrm{N}_{2} \mathrm{O}+2 \mathrm{H}_{2} \mathrm{O}
\end{aligned}
$$

Thus, if nitric acid is used, the formation of $\mathrm{NH}_{4}, \mathrm{NO}_{2}, \mathrm{NO}, \mathrm{N}_{2} \mathrm{O}$ and $\mathrm{N}_{2}$ is expected. Because of the cost, time constraints, and issues associated with introducing significant $\mathrm{NOX}$ and flammable gases into Tanks 1-15, the consideration of using nitric acid, at this time, is considered implausible. 


\section{BASELINE OUTPUT AND VALIDATION}

\subsection{Introduction to Validation}

The purpose of model validation is to show that the model suitably reproduces or models dissolution behavior. The validation is done by comparing model dissolution forecasts to Savannah River National Laboratory (SRNL) measured dissolutions. The types of sludge included Purex sludge, and $\mathrm{H}$-area Modified Processing. Purex sludge is the sludge associated with running a Purex separations campaign, while $\mathrm{H}$ Area Modified (HM) is specific to SRS. As part of validation, the forecasts and the measured dissolutions must result in similar wt\% dissolved sludge. Ideally, as part of validation, the speciation capability of the model would also be validated. The ability to validate the speciation, however, is severely limited, based on the recorded analyzes.

Since the Tank 16 testing showed that only $30 \%$ to $50 \%$ of the oxide matrix had to be weakened to remove the sludge from the tank [West, 1980], dissolution in the laboratory is more restrictive than actual in-tank sludge heel removal. Alternately stated, historical evidence shows that if only $30-50 \%$ of the in-tank sludge dissolves, complete removal will occur.

Because of the need to validate the model with measured dissolutions, wellcharacterized simulants are used. A second step includes validation with Purex sludge and HM sludge. For Tank $8 \mathrm{~F}$ Purex sludge, model forecasts are consistent with SRNL measured dissolution results. Because of problems with the Tank $12 \mathrm{HM}$ sludge sample, historic Tank 16HM results were used instead [Bradley, 1977:15].

\section{2 Validation of Model Using Simulant}

Based on historical records, only two streams, Purex and HM represent the SRS sludge in Tanks 1-15. Because of the need to validate the model forecasts with measured tests, well-characterized simulants are first used. Recipes for the SRNL to make the Purex simulant and HM simulant are provided in Hobbs [2003: 12\&14]. Although provided as a recipe, these also characterize the contents of the simulant. 
The recipe/characterization for the Purex simulant and HM simulant is shown in Table 4-1.

Table 4-1 Purex and HM Simulant Constituents

\begin{tabular}{|c|c|c|}
\hline \multirow{2}{*}{ Constituent } & Purex Sludge Simulant Recipe & HM Sludge Simulant Recipe \\
\cline { 2 - 3 } & \multicolumn{2}{|c|}{ (mole) } \\
\hline $\mathrm{Al}(\mathrm{OH})_{3}$ & $2.21 \mathrm{E}-1$ & $1.50 \mathrm{E}+0$ \\
\hline $\mathrm{Ca}_{3}(\mathrm{PO})_{2}$ & $1.49 \mathrm{E}-3$ & $4.80 \mathrm{E}-5$ \\
\hline $\mathrm{Fe}(\mathrm{OH})_{3}$ & $8.37 \mathrm{E}-1$ & $1.75 \mathrm{E}-1$ \\
\hline $\mathrm{Mg}(\mathrm{OH})_{2}$ & $2.55 \mathrm{E}-2$ & $1.20 \mathrm{E}-2$ \\
\hline $\mathrm{Mn}(\mathrm{OH})_{2}$ & $4.70 \mathrm{E}-1$ & $1.09 \mathrm{E}-1$ \\
\hline $\mathrm{Mn}(\mathrm{PO} 4)_{2}$ & $1.10 \mathrm{E}-2$ & $1.10 \mathrm{E}-2$ \\
\hline $\mathrm{HgO}$ & $1.85 \mathrm{E}-3$ & $2.58 \mathrm{E}-2$ \\
\hline $\mathrm{Ni}(\mathrm{OH})_{2}$ & $8.99 \mathrm{E}-1$ & $1.60 \mathrm{E}-2$ \\
\hline
\end{tabular}

\subsubsection{Measured Simulant Dissolutions}

SRNL measured the laboratory dissolution of Purex sludge simulant and HM sludge simulant using one acid strike and seven acid strikes of $4 \mathrm{wt} \%$ oxalic acid solution in 2:1 and 50:1 volume ratios of acid solution to simulants. Details are recorded in the literature [Hobbs, 2003:14] and the results are summarized in Table 4-2.

Table 4-2 Measured Purex and HM Simulant Dissolutions

\begin{tabular}{|l|c|c|c|c|c|}
\hline Scenario & Total & Al & Fe & Mn & Ni \\
\hline & \multicolumn{5}{|c|}{ (Dissolved wt\%) } \\
\hline 1 strike @ 2:1Purex & 3.7 & 9.4 & 3.4 & 3.4 & 2.9 \\
\hline 7 strikes @ 50:1 purex & 40.8 & 46.0 & 41.4 & 42.6 & 36.2 \\
\hline 1 strike @ 50:1Purex & 83.7 & 69.2 & 79.8 & 99.1 & 95.3 \\
\hline 7 strikes @ 50:1Purex & 87.2 & 81.8 & 84.4 & 99.1 & 95.3 \\
\hline 1 strike @ 2:1 HM & 1.9 & 0.7 & 1.1 & 8.9 & 10.8 \\
\hline 7 strikes @ 2:1 HM & 26.7 & 25.2 & 25.0 & 42.8 & 56.6 \\
\hline 1 strike @ 50:1 HM & 76.4 & 42.0 & 70.8 & 96.9 & 100 \\
\hline 7 strikes @ 50:1 HM & 81.6 & 60.9 & 77.5 & 97.0 & 100 \\
\hline
\end{tabular}


Based on the SRNL measured dissolutions, Table 4-2 shows that as more oxalic acid is added, in terms of either strikes or volume ratios, more sludge will be dissolved.

\subsubsection{Forecasts of Simulant Dissolutions}

The dissolution of Purex sludge simulant and HM sludge simulant corresponding to the SRNL dissolutions discussed in Section 4.2.1 are modeled [Hobbs, 2003:12]. The model dissolution forecasts for total $\mathrm{Al}, \mathrm{Fe}, \mathrm{Mn}$, and $\mathrm{Ni}$ wt\% dissolved are shown in Table 4-3. In agreement with Table 4-2, one acid strike and seven acid strikes of 4 wt\% oxalic acid solutions in 2:1 and 50:1 volume ratios of acid solution to simulant, were used. The results are shown in Table 4-3.

Table 4-3 Forecast of Purex and HM Simulant Dissolutions

\begin{tabular}{|c|c|c|c|c|c|}
\hline Scenario & Total & Al & $\mathrm{Fe}$ & Mn & $\mathbf{N i}$ \\
\hline & \multicolumn{5}{|c|}{ (Dissolved wt\%) } \\
\hline 1 strike @ 2:1purex & 27.9 & 28.3 & 28.0 & 26.6 & 28.0 \\
\hline 7 strikes @ 2:1purex & 29.4 & 28.0 & 31.6 & 27.5 & 35.2 \\
\hline 1 strike @ 50:1purex & 57.0 & 83.2 & 100 & 26.1 & 28.1 \\
\hline 7 strikes @ 50:1purex & 73.3 & 100 & 100 & 26.3 & 28.1 \\
\hline 1 strike @ 2:1 HM & 30.4 & 28.4 & 28.1 & 44.4 & 28.0 \\
\hline 7 strikes @ 2:1 $\mathrm{HM}$ & 90.9 & 90.6 & 100 & 99.2 & 90.0 \\
\hline 1 strike $@ 50: 1_{\mathrm{HM}}$ & 72.8 & 70.2 & 100 & 69.2 & 35.4 \\
\hline 7strikes @ 50:1 $\mathrm{HM}$ & 100 & 100 & 100 & 100 & 100 \\
\hline
\end{tabular}

\subsubsection{Forecast vs Measured Simulant Dissolutions}

A comparison between forecasts and the SRNL measured dissolutions for one acid strike and seven acid strikes of 4 wt\% oxalic acid solution, using 2:1 and 50:1 volume ratios of oxalic acid solution to Purex sludge simulant and HM sludge simulant, are shown in Table 4-4. 
Table 4-4 Forecast vs Measured Purex and HM Simulant Dissolutions

\begin{tabular}{|c|c|c|c|c|c|c|}
\hline \multirow[t]{2}{*}{ Scenario } & \multirow[t]{2}{*}{ Results } & Total & Al & $\mathrm{Fe}$ & Mn & $\mathbf{N i}$ \\
\hline & & \multicolumn{5}{|c|}{ (Dissolved wt\%) } \\
\hline \multirow{3}{*}{1 strike @ 2:1purex } & Model & 27.9 & 28.3 & 28.0 & 26.6 & 28.0 \\
\hline & SRNL & 3.7 & 9.4 & 3.4 & 3.4 & 2.9 \\
\hline & Fraction & 7.5 & 3.0 & 8.2 & 7.8 & 9.7 \\
\hline \multirow{3}{*}{7 strike @ 2:1purex } & Model & 29.4 & 28.0 & 31.6 & 27.5 & 35.2 \\
\hline & SRNL & 40.8 & 46.0 & 41.4 & 42.6 & 46.2 \\
\hline & Fraction & 0.7 & 0.6 & 0.8 & 0.7 & 1.0 \\
\hline \multirow{3}{*}{1 strike @ 50:1Purex } & Model & 57.0 & 83.2 & 100 & 26.1 & 28.1 \\
\hline & SRNL & 83.7 & 69.2 & 79.8 & 99.1 & 95.3 \\
\hline & Fraction & 0.7 & 1.2 & 1.3 & 0.3 & 0.3 \\
\hline \multirow{3}{*}{7 strikes @ 50:1purex } & Model & 73.3 & 100 & 100 & 26.3 & 28.1 \\
\hline & SRNL & 87.2 & 81.8 & 84.4 & 99.1 & 95.3 \\
\hline & Fraction & 0.8 & 1.2 & 1.2 & 0.3 & 0.3 \\
\hline \multirow{3}{*}{ 1strike @ 2:1 HM } & Model & 30.4 & 28.4 & 28.1 & 44.4 & 28.0 \\
\hline & SRNL & 1.9 & 0.7 & 1.1 & 8.9 & 10.8 \\
\hline & Fraction & 16.0 & 40.6 & 25.6 & 5.0 & 2.6 \\
\hline \multirow{3}{*}{7 strikes @ 2:1HM } & Model & 90.9 & 90.6 & 100 & 99.2 & 90.0 \\
\hline & SRNL & 26.7 & 25.2 & 25.0 & 42.8 & 56.6 \\
\hline & Fraction & 3.4 & 3.6 & 4.0 & 2.3 & 1.6 \\
\hline \multirow{3}{*}{1 strike @ 50:1HM } & Model & 72.8 & 70.2 & 100 & 69.2 & 35.4 \\
\hline & SRNL & 76.4 & 42.0 & 70.8 & 96.9 & 100 \\
\hline & Fraction & 1.0 & 1.7 & 1.4 & 0.7 & 0.4 \\
\hline \multirow{3}{*}{7 strikes @ 50:1HM } & Model & 100 & 100 & 100 & 100 & 100 \\
\hline & SRNL & 81.6 & 60.9 & 77.5 & 97.0 & 100 \\
\hline & Fraction & 1.2 & 1.6 & 1.3 & 1.0 & 1.0 \\
\hline
\end{tabular}

As shown in Table 4-4, for even one acid strike at a 50:1 volume ratio (acid solution to sludge simulant) of $4 \mathrm{wt} \%$ of oxalic acid solution, the forecast and measured dissolutions have similar types of results. Starting from one acid strike of $4 \mathrm{wt} \%$ oxalic acid at a 50:1 volume ratio for both Purex sludge simulant and HM sludge simulant, as the amount of acid increases (in terms of either volume ratio or total wt\%) the forecasts and measured dissolutions more closely match. For Purex sludge simulant, Figure 4-1 compares the forecast of one acid strike of $4 \mathrm{wt} \%$ oxalic acid solution in a 50:1 volume ratio to the SR NL laboratory measured dissolutions. 


\section{Purex Simulant Dissolution}

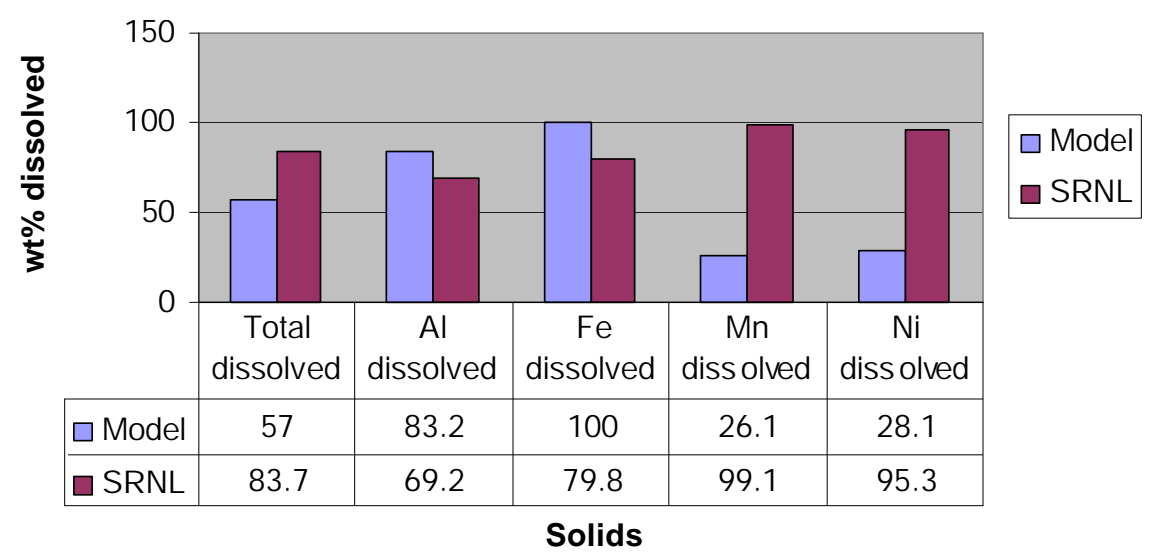

\section{Figure 4-1 Forecast vs Measured Purex Sludge Simulant Dissolutions}

The one strike $4 w t \%$ oxalic acid solution in a $50: 1$ volume ratio of acid solution to Purex sludge simulant is within $33 \%$ of the SRNL dissolution. Upon closer observation; however, the wt\% aluminum and iron are overestimated, while the manganese and nickel are underestimated. The difference between the forecast and the SRNL measured results can most likely be attributed to the re-precipitation of manganese and nickel as newly formed oxalate compounds within the model. The ultimate fate of the $\mathrm{Al}(\mathrm{OH})_{3}, \mathrm{Fe}(\mathrm{OH})_{3}, \mathrm{Mn}(\mathrm{OH})_{2}$, and $\mathrm{NI}(\mathrm{OH})_{2}$ are discussed and quantified in Appendix 2, Table A2-1.

Figure 4-2 compares the HM sludge simulant modeled dissolution forecasts to the SRNL laboratory dissolutions for a one strike, 4 wt\% oxalic acid solution, in a 50:1 volume ratio of acid solution to sludge simulant. 
HM Simulant Dissolution

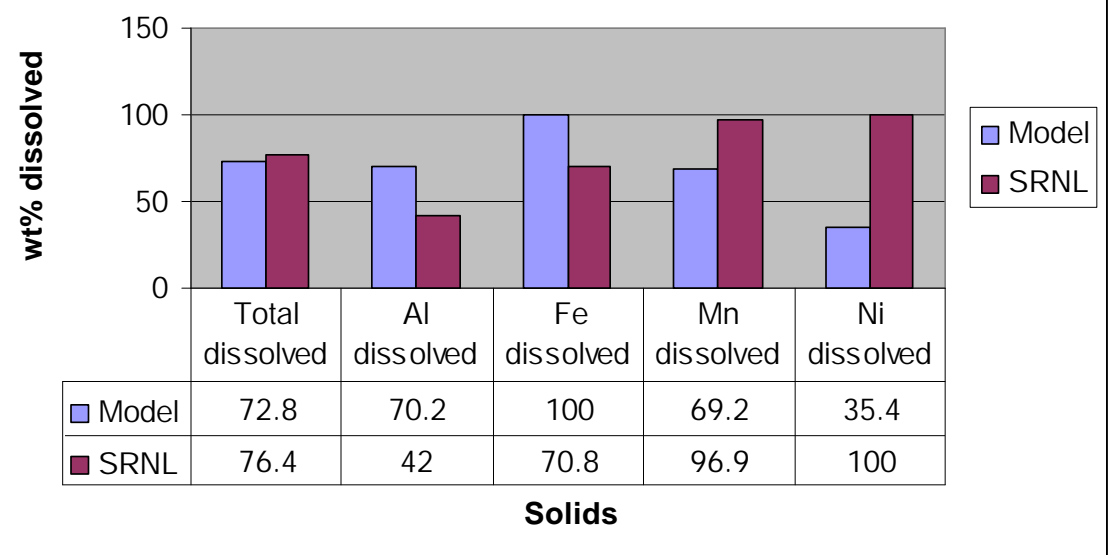

Figure 4-2 Forecast vs Measured HM Sludge Simulant Dissolutions

Although for the one strike, 4 wt\%, 50:1 volume ratio of oxalic acid to HM sludge simulant, the model could be considered to approximate the total sludge wt\% dissolved; again the model wt\% dissolution of nickel and manganese are significantly less than the SRNL measured wt\% dissolved. The difference between the model forecasts and the SRNL measured dissolution results could most likely be attributed to the models equilibrium re-precipitation of manganese and nickel as newly formed oxalate compounds. The ultimate fate of the $\mathrm{Al}(\mathrm{OH})_{3}, \mathrm{Fe}(\mathrm{OH})_{3}, \mathrm{Mn}(\mathrm{OH})_{2}$, and $\mathrm{NI}(\mathrm{OH})_{2}$ are discussed and quantified in Appendix 2, Table A2-2.

Since the relative wt\% of manganese and wt $\%$ nickel are lower in actual Tanks 1-15 Purex sludge and HM sludge, than in the simulant, the complexities associated with manganese and nickel are maximized in the simulants. The forecasts for Tanks 115 sludge to laboratory measured dissolutions will result in much closer similarity. From Figure 4-1 and Figure 4-2, it can be predicted that a model forecast for total sludge dissolved for one strike of $4 \mathrm{wt} \%$ oxalic acid solution in a 50:1 volume ratio of acid solution to sludge simulant, will approximately match that for SRNL measured dissolution for the same simulant. 


\subsection{Validation of Model for Sludge}

Previously taken Tank 8 Purex sludge and Tank 12 HM sludge samples were archived in the laboratory and available for dissolution testing. The Tank 12 sample, however, was extremely dry. As noted, an approximate 65 vol\% liquid is required for $\mathrm{OLI}^{\circ}$ modeling [Badheka, 2003:4]. Since dissolution results from a non-archived (non-dried out) Tank $16 \mathrm{HM}$ sludge are recorded, the Tank 16 results are believed to more accurately reflect expected results. The Tank 16 sludge dissolution results are therefore used for the dissolution of HM sludge. In this research; henceforth, the Tank 12 sludge dissolution results are discounted and no longer used. Comparisons between the model and expected HM sludge dissolution are made using Tank 16 results.

\subsubsection{Measured Tank 8 Purex Sludge Dissolution}

Table 4-5 shows the characterization of the Tank 8 sludge.

Table 4-5 Tank 8 Purex Sludge Constituents

\begin{tabular}{|c|c|}
\hline Constituent & Tank 8 Purex Sludge (mole) \\
\hline $\mathrm{Al}(\mathrm{OH})_{3}$ & $3.6 \mathrm{E}-1$ \\
\hline $\left.\mathrm{Ca}_{3}(\mathrm{PO})_{2}\right)_{2}$ & $6.7 \mathrm{E}-3$ \\
\hline $\mathrm{Fe}(\mathrm{OH})_{3}$ & $2.0 \mathrm{E}+0$ \\
\hline $\mathrm{Mg}(\mathrm{OH})_{2}$ & 0 \\
\hline $\mathrm{Mn}(\mathrm{OH})_{2}$ & $2.6 \mathrm{E}-1$ \\
\hline $\mathrm{Mn}(\mathrm{PO})_{2}$ & $6.1 \mathrm{E}-3$ \\
\hline $\mathrm{HgO}$ & $3.0 \mathrm{E}-3$ \\
\hline $\mathrm{Ni}(\mathrm{OH})_{2}$ & $2.0 \mathrm{E}+0$ \\
\hline
\end{tabular}

The SRNL laboratory dissolution of Tank 8 Purex sludge for one strike of 4 wt\% oxalic acid solution using a 50:1 volume ratio of oxalic acid to sludge was measured. Details are recorded [Hobbs, 2003:33], and the results are summarized in Table 4-6. 
Table 4-6 Measured Tank 8 Purex Sludge Dissolution

\begin{tabular}{|c|c|}
\hline Scenario & Total Sludge Dissolved (wt\%) \\
\hline 1 strike @ 50:1Purex & 69 \\
\hline
\end{tabular}

\subsubsection{Forecast of Tank 8 Purex Sludge Dissolution}

The dissolution of Tank 8 Purex sludge corresponding to the SRNL dissolution discussed in Section 4.3.1 is modeled. The OLI Stream Analyzer ${ }^{\odot}$ Tank 8 Purex sludge dissolution forecasts for total weight dissolved are shown in Table 4-7.

Table 4-7 Forecast of Tank 8 Purex Sludge Dissolution

\begin{tabular}{|c|c|}
\hline Scenario & Total Sludge Dissolved (wt\%) \\
\hline 1 strike @ 50:1 Purex & 87 \\
\hline
\end{tabular}

As shown in Table 4-7, the model forecasts that not all of the Tank 8 Purex sludge will dissolve.

\subsubsection{Forecast vs Measured Tank 8 Purex Sludge Dissolution}

A comparison between the forecast and the SRNL measured dissolution for one strike of $4 \mathrm{wt} \%$ oxalic acid solution using a 50:1 volume ratio of oxalic acid to sludge for Tank 8 Purex sludge is shown in Table 4-8.

Table 4-8 Forecast vs Measured Tank 8 Purex Sludge Dissolution

\begin{tabular}{|c|c|c|}
\hline Scenario & Results & Total Sludge Dissolved (wt\%) \\
\hline & Model & 87 \\
1 strike @ 50:1purex & SRNL & 69 \\
& Fraction & 1.26 \\
\hline
\end{tabular}

As shown in Table 4-8, the forecast of the Tank 8 Purex one strike of 4 wt $\%$ oxalic acid solution in a volume ratio of 50:1 (acid to sludge), results in an over-estimate of total dissolution. Figure 4-3 graphically compares the Tank 8 Purex sludge dissolution forecast to the SRNL measured results. 


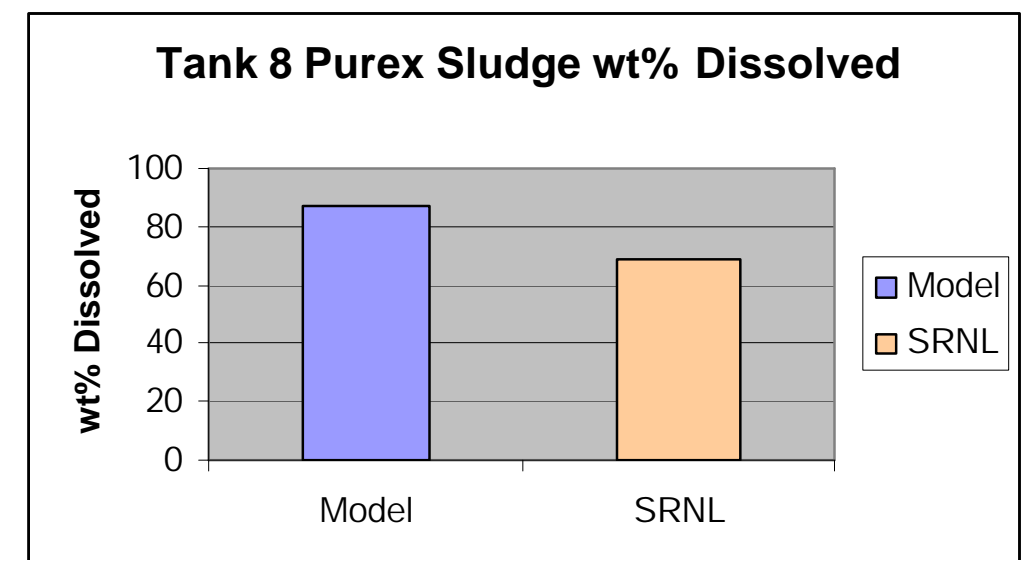

Figure 4-3 Forecast vs Measured Tank 8 Purex Sludge Dissolution

As shown in Figure 4-3, the Tank 8 Purex sludge dissolution, using one strike of 4 wt\% oxalic acid solution, in a volume ratio of 50:1 oxalic acid solution to sludge, results in only a small over-estimate compared to the SRNL measured dissolution results. Overall, the model worked well in forecasting the dissolution of Purex sludge simulant and the Tank $8 \mathrm{P}$ urex sludge sample.

\subsubsection{Measured Tank 16 HM Sludge Dissolution}

In the late 1970's a demonstration was performed on Tank 16 prior to its retirement. The purpose of the demonstration was to access waste removal effectiveness of different processes, including acid cleaning [West, 1980:1]. Although the test was done more than two decades ago, the fact remains that as part of the evaluation for closure, acid dissolution was tested in the laboratory, used in a HLW tank, and eventually declared successful for sludge heel dissolution [West, 1980]. Table 4-9 shows the characterization of the Tank 16 sludge [West, 1980]. 
Table 4-9 Tank 16 HM Sludge Constituents

\begin{tabular}{|c|c|}
\hline Constituent & Tank 16 HM Sludge (mole) \\
\hline $\mathrm{Al}(\mathrm{OH})_{3}$ & $6.9 \mathrm{E}-1$ \\
\hline $\mathrm{Fe}(\mathrm{OH})_{3}$ & $1.8 \mathrm{E}+0$ \\
\hline $\mathrm{Mn}(\mathrm{OH})_{2}$ & $3.3 \mathrm{E}-1$ \\
\hline $\mathrm{Mn} 3(\mathrm{PO})_{2}$ & $1.1 \mathrm{E}-2$ \\
\hline $\mathrm{HgO}$ & $6.5 \mathrm{E}-2$ \\
\hline $\mathrm{Ni}(\mathrm{OH})_{2}$ & $1.0 \mathrm{E}-1$ \\
\hline
\end{tabular}

The SR NL laboratory dissolution of Tank 16 HM sludge using a 20:1 acid to sludge volume ratio for two strikes of $8 \mathrm{wt} \%$ oxalic acid are recorded in the referenced literature [West, 1980]. The results are summarized in Table 4-10.

Table 4-10 Measured Tank 16 HM Sludge Dissolutions

\begin{tabular}{|c|c|}
\hline Scenario & Total Sludge Dissolved (wt\%) \\
\hline 2 strikes @ 20:1 HM & 95 \\
\hline
\end{tabular}

\subsubsection{Forecast of Tank 16H HM Sludge Dissolution}

The dissolution of Tank $16 \mathrm{HM}$ sludge corresponding to the SRNL dissolution discussed in Section 4.4.1 is modeled. The OLI Stream Analyzer ${ }^{\odot}$ Tank $16 \mathrm{HM}$ sludge dissolution forecasts for total weight dissolved are shown in Table 4-11.

Table 4-11 Forecast of Tank 16 HM Sludge Dissolution

\begin{tabular}{|c|c|}
\hline Scenario & Total Sludge Dissolved (wt\%) \\
\hline 2 strikes @ 20:1 $1 \mathrm{HM}$ & 80 \\
\hline
\end{tabular}

\subsubsection{Forecast vs Measured Tank 16HM Sludge Dissolution}

The comparison between the SRNL measured dissolution and the $\mathrm{OLI}{ }^{\circ}$ forecast for Tank 16 HM sludge dissolution is shown in Table 4-12. 
Table 4-12 Forecast vs Measured Tank 16 HM Sludge Dissolution

\begin{tabular}{|c|c|c|}
\hline Scenario & Results & Total Sludge Dissolved (wt\%) \\
\hline \multirow{2}{*}{ 2 strikes @ 20:1HM } & Model & 80 \\
& SRNL & 95 \\
& Fraction & 84 \\
\hline
\end{tabular}

As shown in Table 4-12, modeling of two strikes with 8 wt\% oxalic acid solutions, in volume ratios of 20:1 results in an under-estimation of dissolution. This is also shown graphically in Figure 4-4.

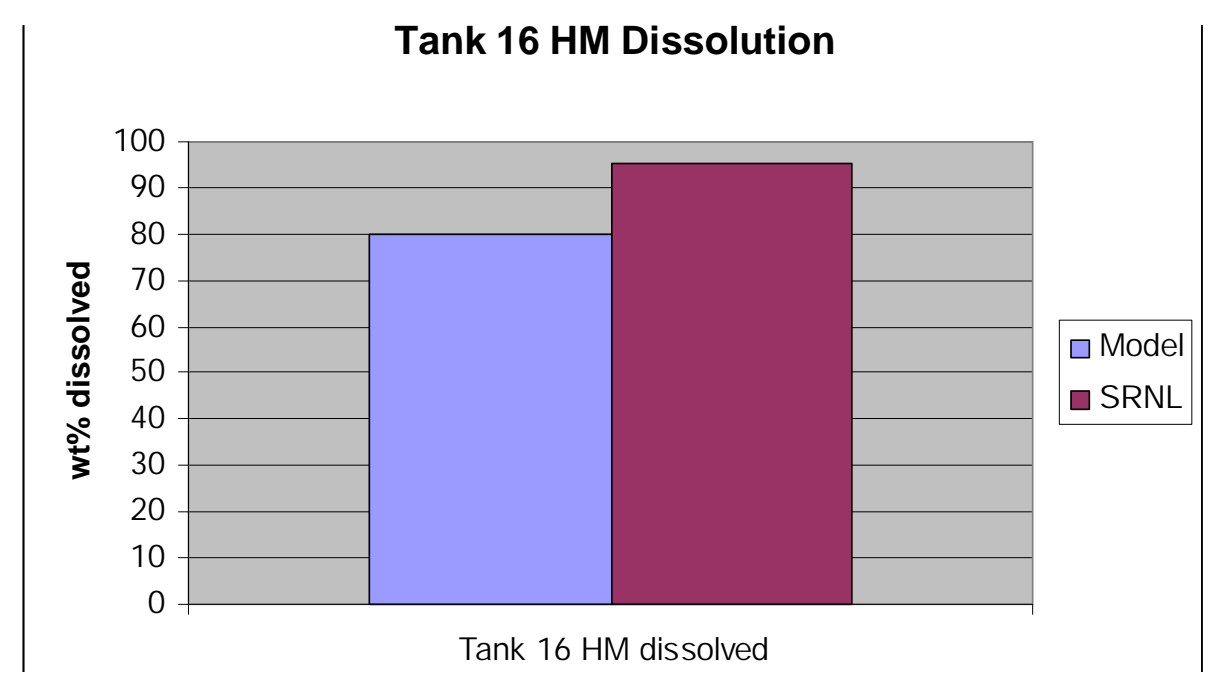

Figure 4-4 Forecast vs Measured Tank 16 HM Sludge Dissolution

Although the forecast and laboratory measurements are not the same, the agreement is well within a range of acceptability. Based on the similarity between the Tank 16 SRNL measured dissolution and the forecast, the model's ability to forecast HM sludge heel dissolution is also considered valid.

\subsection{Validation Conclusion}

For total wt\% of sludge dissolved, all of the forecasts were relatively close to the measured SRNL dissolution results. In fact, no sludge simulant dissolutions had greater than a $32 \%$ difference between forecast and measured dissolutions, while for actual sludge the maximum difference between forecast and measured dissolutions was only $26 \%$. Refer to Table $4-13$. 
Table 4-13 Summary of Forecast vs Measured Dissolutions

\begin{tabular}{|c|c|c|c|}
\hline Scenario & Solute & Results & Total Dissolved (wt\%) \\
\hline \multirow{3}{*}{ 1 strike @ 50:1Purex } & \multirow{2}{*}{ Simulant } & Model & 57.0 \\
& & SR NL & 83.7 \\
& Fraction & 0.68 \\
\hline \multirow{3}{*}{ 1 strike @ 50:1HM } & Simulant & Mode & 72.8 \\
& & SR NL & 76.4 \\
& & Fraction & 0.95 \\
\hline \multirow{2}{*}{ 1 strike @ 50:1Purex } & \multirow{2}{*}{ Tank 8 } & Model & 87 \\
& Sludge & SRNL & 69 \\
& Fraction & 1.26 \\
\hline \multirow{2}{*}{ 2 strikes @ 20:1 1 HM } & \multirow{2}{*}{ Tank 16 } & Model & 80 \\
& Sludge & SRNL & 95 \\
& & Fraction & 0.84 \\
\hline
\end{tabular}

As we see in Table 4-4, as more acid is used, the model forecast and SRNL measured dissolution results for total wt $\%$ dissolved become closer. Based on literature [Adu-Wusu, 2003:71], three strikes of $8 w t \%$ oxalic acid solution in volume ratios of 20:1 oxalic acid solution to sludge are recommended for SRS HLW sludge heel removal. 


\section{SAFETY IMPACTS}

\subsection{Introduction to Material Balance and Safety Impacts}

The purpose of this chapter is as follows:

- To develop a limited materials balance across only the treatment and adjustment tanks from the dissolution of hypothetical worst-case sludge (HWCS).

- To forecast dissolution and safety impacts on the treatment tank and on the adjustment tank from an oxalic acid aided sludge heel removal effort in an SRS HLW Tank 1 through 15.

The recommended cleaning solution consists of three strikes of $8 w t \%$ oxalic acid solution, in a volume ratio of 20:1 oxalic acid solution to sludge [Adu-Wusu, 2003:71] Because of the model running to equilibrium, as expected, the model requires significantly less acid. As part of this chapter, a Hypothetical Worst Case Sludge is first defined, the material balance developed, and the dissolution and the safety impacts evaluated.

\subsection{Hypothetical Worst Case Sludge}

Because there is a myriad of potential compounds and complexes that may exist in HLW, the process database [HLW, 2005] uses a single-species approach in defining the contents of the sludge. In this approach, single representative species are used to account primarily for each of the contained species. It is assumed that programs such as $\mathrm{OLI}^{\circ}$ can then be used to better characterize the specific constituents in the tanks. Although the characterization database must be used carefully, it is extremely beneficial since it enables initial forecasts on effectiveness, safety, and processability to be made, such that resources (e.g., new sampling) can be allocated to only those activities where success seems plausible. 
Because of the complexity associated with characterization, much of the operational activities in HLW rely on the process database. The contents of the sludge as contained in the process database consider [HLW, 2005]:

Radionuclides:

Th-238 (thorium), U-232 (uranium), U-233, U-234, U-235, U-236, U-238, Np236 (neptunium), Np-237, Pu-238 (plutonium), Pu-239, Pu-240, Pu-241, Pu242, Pu-244, H-3 (tritium), Cs-135 (cesium), Cs-137, C-14 (carbon), Co-60 (cobalt), Se-79 (selenium), Y-90 (yttrium), Nb-94 (niobium), Tc-99 (technetium), Ru-106 (ruthenium), R h-106 (rhodium), Sb-125 (antimony),

Sn-126 (tin), I-129 (iodine), Ba-137m (barium), Ce-144 (cerium), Pr-144 (praseodymium), Pm-147 (promethium), Eu-154 (europium), Am-241 (americium), Am-242m, Am-244, Cm-245 (curium).

Chemical Compounds:

$\mathrm{Al}(\mathrm{OH})_{3}$ (aluminum hydroxide), $\mathrm{BaSO}_{4}$ (barium sulfate), $\mathrm{Ca}_{3}(\mathrm{PO})_{4}$ (calcium phosphate), $\mathrm{CaC}_{2} \mathrm{O}_{4}$ (calcium oxalate), $\mathrm{CaF}_{2}$ (calcium fluoride), $\mathrm{CaSO}_{4}$ (calcium sulfate), $\mathrm{Ce}(\mathrm{OH})_{3}$ (cerium hydroxide), $\mathrm{Co}(\mathrm{OH})_{3}$ (cobalt hydroxide), $\mathrm{Cr}(\mathrm{OH})_{3}$ (chromium hydroxide), $\mathrm{Cu}(\mathrm{OH})_{2}$ (copper hydroxide), $\mathrm{Fe}(\mathrm{OH})_{3}$ (iron hydroxide), $\mathrm{HgO}$ (mercury oxide), $\mathrm{KNO}_{3}$ (potassium nitrate), $\mathrm{La}(\mathrm{OH})_{3}$ (lanthanum hydroxide), $\mathrm{Mg}(\mathrm{OH})_{2}$ (magnesium hydroxide), $\mathrm{MnO}_{2}$ (manganese oxide), $\mathrm{Na}_{2} \mathrm{SO}_{4}$, (sodium sulfate), $\mathrm{Na}_{3} \mathrm{PO}_{4}$ (sodium phosphate), $\mathrm{NaCl}$ (sodium chloride), $\mathrm{NaF}$ (sodium fluoride), $\mathrm{Nal}$ (sodium iodide), $\mathrm{NaNO}_{3}$ (sodium nitrate), $\mathrm{NaOH}$ (sodium hydroxide), $\mathrm{Ni}(\mathrm{OH})_{2}$ (nickel hydroxide), $\mathrm{PbCO}_{3}$ (lead carbonate), $\mathrm{PbSO}_{4}$ (lead sulfate), $\operatorname{Pr}(\mathrm{OH})_{3}$ (praseodymium hydroxide), $\mathrm{Pu}(\mathrm{OH})_{4}$ (plutonium hydroxide), $\mathrm{RuO}_{2}$ (ruthenium oxide), $\mathrm{SiO}_{2}$ (silicon dioxide), $\mathrm{SrCO}_{3}$ (strontium carbonate), $\mathrm{ThO}_{2}$ (thorium oxide), $\mathrm{TiO}_{2}$ (tin oxide), $\mathrm{UO}_{2}(\mathrm{OH})_{2}$ (uranyl IV hydroxide), $\mathrm{Zn}(\mathrm{OH})_{2}$ (zinc hydroxide), $\mathrm{Zr}(\mathrm{OH})_{2}$ (zirconium hydroxide).

The process database, however, is not a complete database, as its uncertainty definitively exceeds the tolerance needed to quantify organic and ammonia contents. To ensure data is not inappropriately applied organic and ammonia compounds are therefore not recorded in the database. On a mass basis, the quantity of organics and ammonia compounds required to have a significant impact on flammability are very small. Generally, sample results show that organic and ammonia concentrations within the tanks are near or less than the lower levels of detectability [S wingle, 1999; Britt, 2003; Hobbs, 1999]. Organics and ammonia can not be quantified using the 
process database, nor this material balance, but are addressed separately as part of Chapter 6.

Initially when attempting to determine what sludge would look like for the model input, all of the transfers to Tanks 1-15 were listed, and a worst case transfer of each constituent is defined. Since, approximately 65 vol\% must be water for $\mathrm{OLI}^{\circ}$ to work [Badheka,2003:117]; the solids were too concentrated for the $\mathrm{OLI}^{\circ}$ electrolyte chemistry model to work, resulting in the software "timing out." The strategy that eventually was implemented was to consider the metal constituents of the transfers, accounting for approximately $90 \%$ of the mass [Badheka, 2003:91]. This is in accordance with the validation in Chapter 4 , where the metals accounting for approximately $90 \%$ of the mass were used. Additionally, those constituents that could contribute to safety impacts (i.e., excessive temperature, over pressurization, and hydrogen generation from corrosion) were considered in the input to the model. Table 5-1 compares the constituents in HWCS, Purex sludge simulant, HM sludge simulant, Tank 8 Purex sludge, and Tank 16 HM sludge. 
Table 5-1 Constituents Considered in Modeling

\begin{tabular}{|c|c|c|c|c|c|}
\hline Constituent & HWCS & $\begin{array}{c}\text { Purex } \\
\text { Sludge } \\
\text { Simulant } \\
\end{array}$ & $\begin{array}{c}\text { HM } \\
\text { Sludge } \\
\text { Simulant }\end{array}$ & $\begin{array}{l}\text { Tank } 8 \\
\text { Purex } \\
\text { Sludge } \\
\end{array}$ & $\begin{array}{c}\text { Tank } 16 \text { HM } \\
\text { Sludge }\end{array}$ \\
\hline $\mathrm{AgOH}$ & $\mathrm{X}$ & & & & \\
\hline $\mathrm{Al}(\mathrm{OH})_{3}$ & $x$ & $x$ & $x$ & $x$ & $x$ \\
\hline $\mathrm{CaC}_{2} \mathrm{O}_{4}$ & $\mathrm{x}$ & & & & \\
\hline $\mathrm{CaCO}_{3}$ & $x$ & & & & \\
\hline $\mathrm{Ca}(\mathrm{PO})_{4}$ & & $x$ & $\mathrm{x}$ & $x$ & \\
\hline $\mathrm{Fe}(\mathrm{OH})_{3}$ & $x$ & $x$ & $x$ & $x$ & $x$ \\
\hline $\mathrm{HgO}$ & $x$ & $x$ & $x$ & $x$ & $x$ \\
\hline $\mathrm{KNO}_{3}$ & $x$ & & & & \\
\hline $\mathrm{Mg}(\mathrm{OH})_{2}$ & & $x$ & $X$ & $X$ & \\
\hline $\mathrm{Mn}(\mathrm{OH})_{2}$ & $x$ & $x$ & $x$ & $x$ & $x$ \\
\hline $\mathrm{NaCl}$ & $x$ & & & & \\
\hline $\mathrm{NaNO}_{3}$ & $x$ & & & & \\
\hline $\mathrm{NaOH}$ & $x$ & & & & \\
\hline $\mathrm{Ni}(\mathrm{OH})_{2}$ & $X$ & $x$ & $x$ & $x$ & $x$ \\
\hline $\mathrm{PbCO}_{3}$ & $x$ & & & & \\
\hline $\mathrm{SiO}_{2}$ & $x$ & & & & \\
\hline $\mathrm{UO}_{2}(\mathrm{OH})_{2}$ & $x$ & & & & \\
\hline $\mathrm{SrCO}_{3}$ & $x$ & & & & \\
\hline $\mathrm{Pu}(\mathrm{OH})_{4}$ & $x$ & & & & \\
\hline
\end{tabular}

As seen in Table 5-1, HWCS includes the metal oxides included in the Chapter 4 validation, as well as various other constituents. The range of constituents for sludge transfers to Tanks 1-15 are shown in Table 5-2. 
Table 5-2 Range of Transfer Constituent Sludge Mass for Tanks 1-15

\begin{tabular}{|c|c|c|c|}
\hline \multirow{2}{*}{$\begin{array}{c}\text { Tank Constituents } \\
\mathrm{AgOH}\end{array}$} & \multicolumn{3}{|c|}{$\begin{array}{c}\text { Tank 1-15 Range } \\
(\mathrm{kg})\end{array}$} \\
\hline & 0 & to & $3.73 \mathrm{E}-3$ \\
\hline $\mathrm{Al}(\mathrm{OH})_{3}$ & $9.66 \mathrm{E}-2$ & to & $1.18 \mathrm{E}-1$ \\
\hline $\mathrm{CaC}_{2} \mathrm{O}_{4}$ & 0 & to & $2.46 \mathrm{E}-2$ \\
\hline $\mathrm{CaCO}_{3}$ & $5.41 \mathrm{E}-3$ & to & $6.46 \mathrm{E}-2$ \\
\hline $\mathrm{Fe}(\mathrm{OH})_{3}$ & $2.73 \mathrm{E}-2$ & to & $6.54 \mathrm{E}-1$ \\
\hline $\mathrm{HgO}$ & $6.72 \mathrm{E}-4$ & to & $4.03 E-2$ \\
\hline $\mathrm{KNO}_{3}$ & $9.70 \mathrm{E}-4$ & to & $9.06 \mathrm{E}-3$ \\
\hline $\mathrm{Mn}(\mathrm{OH})_{2}$ & $3.04 \mathrm{E}-2$ & to & $3.47 \mathrm{E}-1$ \\
\hline $\mathrm{NaCl}$ & $8.06 \mathrm{E}-4$ & to & $2.15 \mathrm{E}-2$ \\
\hline $\mathrm{NaNO}_{3}$ & $5.25 \mathrm{E}-3$ & to & $3.83 \mathrm{E}-2$ \\
\hline $\mathrm{NaOH}$ & $1.91 \mathrm{E}-2$ & to & $4.86 \mathrm{E}-2$ \\
\hline $\mathrm{Ni}(\mathrm{OH})_{2}$ & $1.63 \mathrm{E}-4$ & to & $1.35 \mathrm{E}-1$ \\
\hline $\mathrm{PbCO}_{3}$ & $1.02 \mathrm{E}-4$ & to & $2.28 \mathrm{E}-3$ \\
\hline $\mathrm{SiO}_{2}$ & $3.76 \mathrm{E}-3$ & to & $1.24 \mathrm{E}-1$ \\
\hline $\mathrm{UO}_{2}(\mathrm{OH})_{2}$ & $3.15 \mathrm{E}-4$ & to & $1.78 \mathrm{E}-1$ \\
\hline $\mathrm{SrCO}_{3}$ & $7.24 \mathrm{E}-4$ & to & $1.37 \mathrm{E}-3$ \\
\hline $\mathrm{Pu}(\mathrm{OH})_{4}$ & 0 & to & $3.73 E-3$ \\
\hline Total Solids & $7.13 \mathrm{E}-1$ & to & $9.26 \mathrm{E}-1$ \\
\hline
\end{tabular}

Since transfers vary in size, the values contained in Table 5-2 need to be normalized for comparative purposes. To normalize data for comparative purposes, each constituent mass was divided by the total mass (horizontal row) of the considered tank. This is shown in Table 5-3. 
Table 5-3 Normalized Maximum Sludge Mass

\begin{tabular}{|c|c|}
\hline Constituent & Max Mass $\mathbf{( k g / k g}$ total) \\
\hline $\mathrm{AgOH}$ & $4.28 \mathrm{E}-3$ \\
\hline $\mathrm{Al}(\mathrm{OH})_{3}$ & $5.74 \mathrm{E}-1$ \\
\hline $\mathrm{CaC}_{2} \mathrm{O}_{4}$ & $2.70 \mathrm{E}-2$ \\
\hline $\mathrm{CaCO}$ & $7.42 \mathrm{E}-2$ \\
\hline $\mathrm{Fe}(\mathrm{OH})_{3}$ & $7.51 \mathrm{E}-1$ \\
\hline $\mathrm{HgO}$ & $4.42 \mathrm{E}-2$ \\
\hline $\mathrm{KNO}$ & $1.04 \mathrm{E}-2$ \\
\hline $\mathrm{Mn}(\mathrm{OH})_{2}$ & $3.93 \mathrm{E}-1$ \\
\hline $\mathrm{NaCl}$ & $2.47 \mathrm{E}-2$ \\
\hline $\mathrm{NaNO}$ & $4.20 \mathrm{E}-2$ \\
\hline $\mathrm{NaOH}$ & $5.58 \mathrm{E}-2$ \\
\hline $\mathrm{Ni}(\mathrm{OH})_{2}$ & $1.89 \mathrm{E}-1$ \\
\hline $\mathrm{PbCO}$ & $3.03 \mathrm{E}-3$ \\
\hline $\mathrm{SiO}$ & $1.36 \mathrm{E}-1$ \\
\hline $\mathrm{UO} \mathrm{O}_{2}(\mathrm{OH})_{2}$ & $2.50 \mathrm{E}-1$ \\
\hline $\mathrm{SrCO}_{3}$ & $1.78 \mathrm{E}-3$ \\
\hline $\mathrm{Pu}(\mathrm{OH})_{4}$ & $3.72 \mathrm{E}-4$ \\
\hline $\mathrm{Total} \mathrm{SOlids}_{3}$ & 1.0 \\
\hline
\end{tabular}

The "Max Mass kg/kgtotal" Column in Table 5-3 is multiplied by the concentration of dry solids in a gallon of sludge. For conservatism $1.12 \mathrm{~kg}$ total $/$ gal is used, except for plutonium in which $1.32 \mathrm{~kg}$ total/gal is used for conservatism. Additionally, to convert to a "per sludge heel," the concentration per gallon is multiplied by the assumed 5,000 gallon heel size as shown in Equation 5-1.

Mass $=$ Maximum $\mathrm{kg} / \mathrm{kg}_{\text {total }} \times$ concentration of solids $\times$ volume $\quad$ (Eq. 5-1)

Where:

$$
\begin{aligned}
& \text { Volume }=5,000 \text { gallons } \\
& \text { Mass }=\mathrm{kg} \text { of constituent solids per 5,000 gallons of sludge } \\
& \text { Max } \mathrm{kg} / \mathrm{kg} \text { total }=\text { value from Table } 5-3
\end{aligned}
$$


Concentration of dry solids in $1 \mathrm{gal}$ of heel = conservatively assumed to be approx. $1.12 \mathrm{~kg} / \mathrm{gal}$, except for plutonium which is assumed to be $1.32 \mathrm{~kg} / \mathrm{gal}$.

Table 5-4 shows the mass of each constituent in the 5,000-gallon HWCS heel used in the modeling.

Table 5-4 Bounding Hypothetical Worst Case Sludge Heel

\begin{tabular}{|c|c|}
\hline Constituent & Mass $\mathbf{k g} / \mathbf{5 0 0 0}$ gallons of HWCS) \\
\hline $\mathrm{AgOH}$ & $2.4 \mathrm{E}+0$ \\
\hline $\mathrm{Al}(\mathrm{OH})_{3}$ & $3.2 \mathrm{E}+3$ \\
\hline $\mathrm{CaC}_{2} \mathrm{O}_{4}$ & $1.5 \mathrm{E}+1$ \\
\hline $\mathrm{CaCO}$ & $4.2 \mathrm{E}+2$ \\
\hline $\mathrm{Fe}(\mathrm{OH})_{3}$ & $4.2 \mathrm{E}+3$ \\
\hline $\mathrm{HgO}$ & $2.5 \mathrm{E}+2$ \\
\hline $\mathrm{KNO}_{3}$ & $5.9 \mathrm{E}+1$ \\
\hline $\mathrm{Mn}(\mathrm{OH})_{2}$ & $2.3 \mathrm{E}+3$ \\
\hline $\mathrm{NaCl}$ & $1.4 \mathrm{E}+2$ \\
\hline $\mathrm{NaNO}$ & $2.4 \mathrm{E}+2$ \\
\hline $\mathrm{NaOH}$ & $3.2 \mathrm{E}+2$ \\
\hline $\mathrm{Ni}(\mathrm{OH})_{2}$ & $1.1 \mathrm{E}+3$ \\
\hline $\mathrm{PbCO}$ & $1.7 \mathrm{E}+1$ \\
\hline $\mathrm{SiO}_{2}$ & $6.9 \mathrm{E}+2$ \\
\hline$U \mathrm{UO}_{2}(\mathrm{OH})_{2}$ & $1.4 \mathrm{E}+3$ \\
\hline $\mathrm{SrCO}_{3}$ & $1.78 \mathrm{E}-3$ \\
\hline $\mathrm{Pu}(\mathrm{OH})_{4}$ & $2.5 \mathrm{E}+0$ \\
\hline
\end{tabular}

\subsection{Supernate in Adjustment Tank}

The supernate characterization data is also taken from the process database (HLW, 2005). The choice of data is limited to the currently proposed receipt tanks and Tank 33, based on the potential for transfers. The data is shown in Table 5-5. 
Table 5-5 Supernate Characterization

\begin{tabular}{|c|c|c|c|c|}
\hline \multirow{2}{*}{ Constituent } & Tank 8 & \multicolumn{1}{|c|}{ Tank 13 } & Tank 33 & Max \\
\cline { 2 - 5 } & \multicolumn{4}{|c|}{ (kg) } \\
\hline $\mathrm{Ag}$ & $1.14 \mathrm{E}-5$ & $1.51 \mathrm{E}-7$ & $1.51 \mathrm{E}-7$ & $1.51 \mathrm{E}-7$ \\
\hline $\mathrm{Al}$ & $2.59 \mathrm{E}-1$ & $3.81 \mathrm{E}-1$ & $1.08 \mathrm{E}-1$ & $3.81 \mathrm{E}-1$ \\
\hline $\mathrm{CO}_{3}$ & $3.18 \mathrm{E}-2$ & $3.41 \mathrm{E}-2$ & $4.54 \mathrm{E}-2$ & $4.54 \mathrm{E}-2$ \\
\hline $\mathrm{C}_{2} \mathrm{O}_{4}$ & $2.60 \mathrm{E}-3$ & $2.27 \mathrm{E}-3$ & $2.27 \mathrm{E}-3$ & $2.60 \mathrm{E}-3$ \\
\hline $\mathrm{Fe}$ & $1.06 \mathrm{E}-4$ & $6.76 \mathrm{E}-5$ & $6.76 \mathrm{E}-5$ & $6.76 \mathrm{E}-5$ \\
\hline $\mathrm{Hg}$ & $1.14 \mathrm{E}-4$ & $7.57 \mathrm{E}-5$ & $7.57 \mathrm{E}-5$ & $7.57 \mathrm{E}-5$ \\
\hline $\mathrm{Mn}$ & $3.19 \mathrm{E}-6$ & $2.61 \mathrm{E}-6$ & $3.22 \mathrm{E}-6$ & $3.22 \mathrm{E}-6$ \\
\hline $\mathrm{Ni}$ & $1.14 \mathrm{E}-5$ & $9.48 \mathrm{E}-6$ & $1.15 \mathrm{E}-5$ & $1.15 \mathrm{E}-5$ \\
\hline $\mathrm{NO} 2$ & $4.79 \mathrm{E}-1$ & $5.29 \mathrm{E}-1$ & $4.70 \mathrm{E}-1$ & $5.29 \mathrm{E}-1$ \\
\hline $\mathrm{NO}$ & $4.69 \mathrm{E}-1$ & $5.28 \mathrm{E}-1$ & $3.76 \mathrm{E}-1$ & $5.28 \mathrm{E}-1$ \\
\hline $\mathrm{NaOH}$ & 0.65 used & 0.65 used & 0.65 used & 0.65 used \\
\hline
\end{tabular}

The values were converted to the simplest compounds of $\mathrm{OH}^{-}$, except for $\mathrm{NaOH}$ that was based on maintaining the corrosion control program. For 5000 gallons the model input is shown in Table 5-6.

Table 5-6 Model Input for $\mathbf{5 0 0 0}$ gallons of Bounding Supernate

\begin{tabular}{|c|c|}
\hline Constituent & Mass $\mathbf{( k g / 5 0 0 0 ~ g a l ~ o f ~ H W C S ) ~}$ \\
\hline $\mathrm{AgOH}$ & $1.74 \mathrm{E}+0$ \\
\hline $\mathrm{Al}(\mathrm{OH})_{3}$ & $5.50 \mathrm{E}+3$ \\
\hline $\mathrm{Na}_{2} \mathrm{CO}_{3}$ & $5.23 \mathrm{E}+2$ \\
\hline $\mathrm{HgC} \mathrm{O}_{4}$ & $1.87 \mathrm{E}+1$ \\
\hline $\mathrm{Fe}(\mathrm{OH})_{3}$ & $1.01 \mathrm{E}+0$ \\
\hline $\mathrm{HgO}$ & $7.7 \mathrm{E}+0$ \\
\hline $\mathrm{Mn}(\mathrm{OH})_{2}$ & $2.61 \mathrm{E}-2$ \\
\hline $\mathrm{Ni}(\mathrm{OH})_{2}$ & $9.06 \mathrm{E}-2$ \\
\hline $\mathrm{HNO}$ & $2.70 \mathrm{E}+3$ \\
\hline $\mathrm{NaNO}$ & $9.76 \mathrm{E}+3$ \\
\hline $\mathrm{NaOH}$ & $3.25 \mathrm{E}+3$ \\
\hline
\end{tabular}




\subsection{Material /Energy Balance and Safety Impacts}

The purpose of the material balance is to estimate the contents in the treatment tank and adjustment tank throughout each evolution of the treatment.

\subsubsection{Hypothetical W orst Case Sludge Material Balance}

A material balance diagram for the three acid strikes is shown in Figure 5-1.

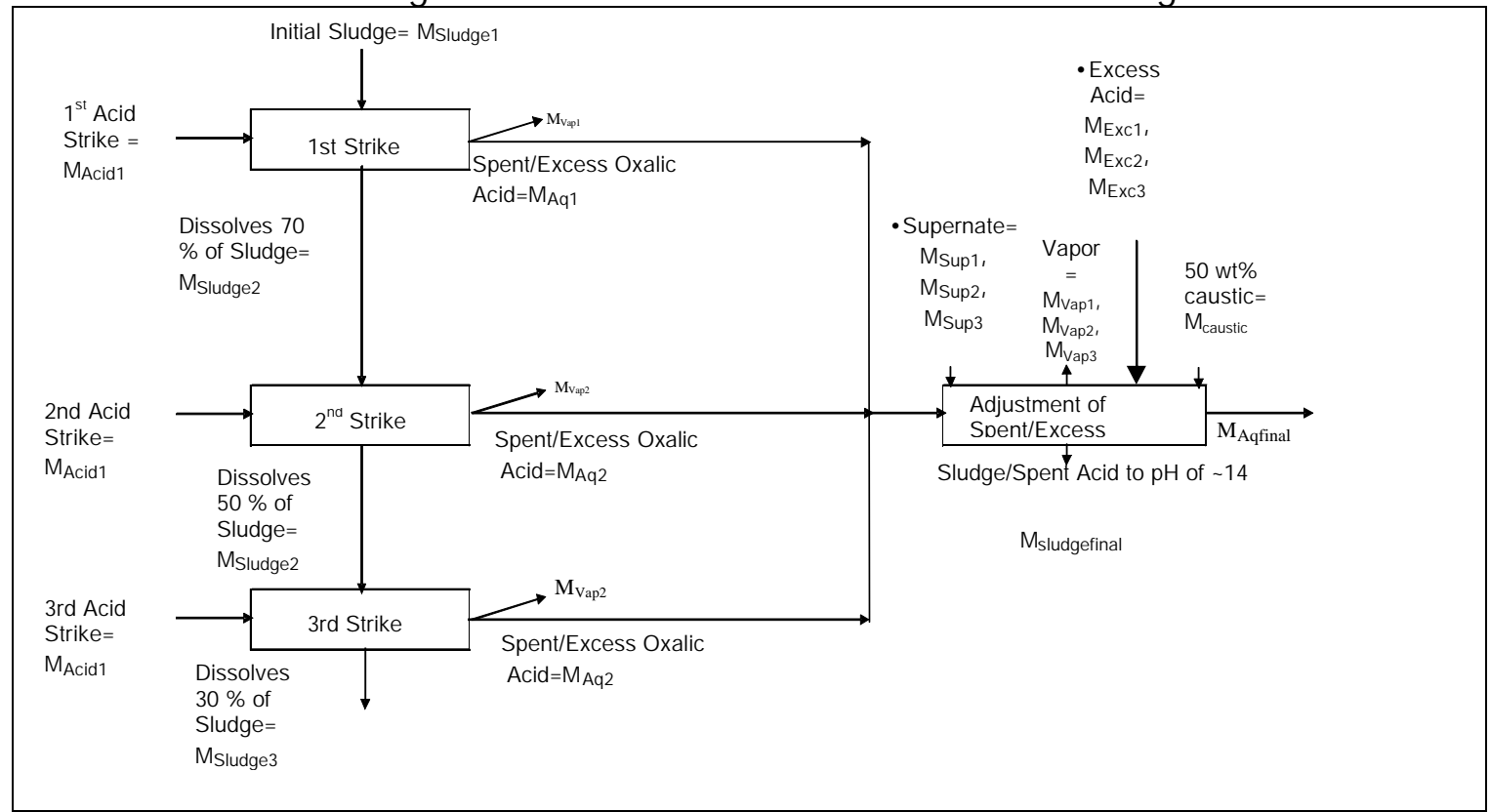

Figure 5-1 Treatment and Adjustment Tank Material Balance Diagram

Initially, the oxalic acid solution (MAcidN) will be added to the HWCS heel (MsludgeN), mixed, and allowed to come to equilibrium. The resultant chemistry is made up of three parts (solid $=M_{\text {SludgeN }+1}$, liquid $=M_{A q N}$, and gas $=M_{V a p N}$ ) based on their physical phase. This is shown by Equation 5-2.

$$
M_{\text {AcidN }}+M_{\text {SludgeN }}=M_{\text {SludgeN }+1}+M_{\text {AqN }}+M_{\text {VapN }}
$$


Where:

"N" = Acid strike number (i.e., first strike, second strike, or third strike)

MSludgeN = Sludge at the beginning of strike " $\mathrm{N}$ "

MSludgeN $+1=$ Sludge remaining in the treatment tank after strike " $\mathrm{N}$ "

$\mathrm{M}_{\mathrm{AqN}}=$ Aqueous that results from strike " $\mathrm{N}$ " and is made from dissolved sludge/reacted acid and will be transferred to the adjustment tank

$\mathrm{M}_{\mathrm{VapN}}=$ Vapor that will be released from the treatment tank after strike " $\mathrm{N}$ "

$\mathrm{M}_{\text {AcidN }}=$ Acid needed for desired dissolution in Strike " $\mathrm{N}$ "

This equation does not include unreacted acid, $\mathrm{M}_{\mathrm{ExCN}}$; therefore, to show unreacted acid in the system we can add it to both sides as shown in Equation 5-3.

$$
M_{E x c N}+M_{\text {AcidN }}+M_{\text {SludgeN }}=M_{\text {SludgeN }}+M_{\text {AqN }}+M_{\operatorname{VapN}}+M_{E x c N}
$$

Where:

$\mathrm{M}_{\mathrm{ExCN}}=\mathrm{Excess}$ acid that does not react in the treatment tank, but passes through the system until reacting in the adjustment tank

For the three strikes in the treatment tank, this is expressed as Equation 5-4.

$$
M_{\text {Sludge } 1}+\sum_{N} M_{\text {Acid }}+\sum_{N} M_{\text {Excess }}=M_{\text {Sludge } 4}+\sum_{N} M_{A q}+\sum_{N} M_{V a p}+\sum_{N} M_{E x c} \quad \text { (Eq. 5-4) }
$$

MVap1, MVap2, and MVap3 are released to the atmosphere from the treatment tank. $M_{\text {Sludge4 }}$ is the remaining sludge heel, while $M_{A q 1}, M_{A q 2}, M_{A g 3}, M_{E x c 1}, M_{E x c 2}$, and MExc3 are added to the adjustment tank. The adjustment tank is initially assumed to have a heel of 10,000 gallons of supernate $\left(M_{S n a t e 1}\right)$ and be pre-treated with a heel of 50 wt\% $\mathrm{NaOH}$ solution, $\mathrm{M}_{\text {Caustic }}$ to ensure corrosion control. It should be noted that large additions of 50 wt\% caustic are normal evolutions evaluated to be 
acceptable as part of maintaining the corrosion control program. The material balance for the adjustment tank is shown as Equation 5-5.

$$
M_{\text {Snate1 }}+M_{\text {Caustic }}+\sum_{N} M_{A q}+\sum_{N} M_{E x C}=\sum_{N} M_{P r e c}+\sum_{N} M_{\text {gas }}+M_{\text {Snate } 2}
$$

Where:

$$
\begin{aligned}
& \text { MSnate1 = Initial supernate in adjustment tank } \\
& M_{\text {Caustic }}=\text { Estimated caustic pre-added to the adjustment tank to ensure } \mathrm{pH} \\
& \text { remains within corrosion control program } \\
& \sum M_{A q}=M_{A q 1}+M_{A q 2}+M_{A q 3}=\text { Dissolved sludge/spent acid each added } \\
& \text { individually transferred from treatment tank to adjustment tank } \\
& \sum M_{E x C}=M_{E x c 1}+M_{E x c 2}+M_{E x c 3}=\text { Unspent acid added during strikes, but does } \\
& \text { not react in system until reaching the } \mathrm{pH} \text { adjustment tank. Each } \\
& \text { excess transferred with corresponding aqueous (i.e., } M_{A g 1}+M_{E x c 1} \\
& \text { transferred from treatment tank, } \mathrm{M}_{\mathrm{Acid} 2} \text { added to treatment tank } \\
& \text { and mixed, and then } \mathrm{M}_{\mathrm{Ag} 2}+\mathrm{M}_{\mathrm{Exc} 2} \text { transferred out of treatment tank } \\
& \text { to the adjustment tank) } \\
& \sum M_{\text {Prec }}=M_{\text {Prec } 1}+M_{\text {Prec2 }}+M_{\text {Prec } 3}=\text { Precipitate that forms in the adjustment } \\
& \text { tank after transfers from treatment tank } \\
& \sum M_{G a s}=M_{G a s 1}+M_{G a s 2}+M_{G a s 3}=p H \text { adjustment vapor produced from } \\
& \text { aqueous and excess acid of strike transferred into the adjustment } \\
& \text { tank } \\
& M_{\text {SnateEnd }}=E \text { nd Aqueous in the adjustment tank after } \sum M_{A q} \text { and } \sum M_{E x c} \\
& \text { additions to the adjustment tank and reactions complete }
\end{aligned}
$$




\subsubsection{Modeling Input and Assumptions}

For speciation, the amount of oxalic acid to be added is based on obtaining 70 vol\%, 50 vol\% and 30 vol\%, as determined by using OLI Stream Analyzer. ${ }^{\circ}$ Adu-Wusu, [2003:p71] recommends that $8 w$ t\% oxalic acid solutions in volume ratios of 20:1 acid to sludge be used to dissolve the sludge. The excess acid will be assumed not to react, but pass through the system with the aqueous until finally reacting within the adjustment tank. No corrosion inhibitors will be required to be added to the treatment tank during acid cleaning or post acid cleaning. Currently, since the treatment tank will be closed, without significant process changes/requirements, no additional $\mathrm{NaOH}$ will be added to the treatment tank.

Salt/supernate is removed prior to acid heel dissolution, based on space availability and ease of separation. The minimum pump down level is assumed 5,000 gallons. At the minimum pump down level, the tank will initially contain the 5,000 gallon heel of HWCS and 70 vol\% of which is assumed to be interstitial liquid, which has been rinsed down to mostly water.

Acid can contact the sludge, because the surface of the sludge after bulk removal should be relatively uniform. Additionally, adequate time will be allowed for the reactions to come to equilibrium. Oxalic acid vapors are minimized for the material balance. Bounding calculations based on an energy balance are used to calculate input for overpressurization concerns.

Small additions, round offs, and speciation simplification based on perceived process, risk importance, and over-all concentration are acceptable based on the likelihood that they are within the uncertainty. This includes the interstitial liquid since the volume is very small compared to the volume of the acid solution.

Solids carryover is considered negligible for the speciation and is not factored into the model (i.e., currently without knowing the pumping capabilities of the system, only dissolved solids are considered to be transferred in the mass balance. Furthermore, this is outside the scope of the material balance). Enthalpy, temperature, gas generation, and dissolution can be independently maximized. Such an approach is 
conservative. The HWCS volume, when acid heel dissolution begins, is limited to about 5,000 gallons.

Based on size of tanks, and the fact that no significant temperature changes are expected, modeling is performed isothermically, assuming the HLW tanks are at $50^{\circ} \mathrm{C}$. When added, the oxalic acid solution and the $50 \mathrm{wt} \%$ sodium hydroxide solution are at $25 \circ \mathrm{C}$.

\subsubsection{Material Balance Modeling}

The input screen for the initial 5,000-gallon Msludge1 uses Table 5-4 and is shown in Figure 5-2. In addition to HWCS the interstitial liquid is assumed to be water and occupies 70 vol\% of the sludge.

\begin{tabular}{|c|c|c|}
\hline varrable & value & Unit \\
\hline \multicolumn{3}{|c|}{ Stream Parameters } \\
\hline Strearn Arnt - Total Inflow & 27769.5 & $\mathrm{~kg}$ \\
\hline Temperature & 50.0 & ${ }^{\circ} \mathrm{C}$ \\
\hline Pressure & 1.0 & atm \\
\hline \multicolumn{3}{|c|}{ Calc Parameters } \\
\hline \multicolumn{3}{|c|}{ Inflows } \\
\hline $\mathrm{H} 2 \mathrm{O}$ & 13247.0 & $\mathrm{~kg}$ \\
\hline $\mathrm{AgOH}$ & 24.0 & $\mathrm{~kg}$ \\
\hline $\mathrm{Al}(\mathrm{OH}) 3$ & 3200.0 & $\mathrm{~kg}$ \\
\hline $\mathrm{CaC} 2 \mathrm{O} 4$ & 150.0 & $\mathrm{~kg}$ \\
\hline $\mathrm{CaCO} 3$ & 420.0 & $\mathrm{~kg}$ \\
\hline $\mathrm{Fe}(\mathrm{OH}) 3$ & 4200.0 & $\mathrm{~kg}$ \\
\hline $\mathrm{HgO}$ & 250.0 & $\mathrm{~kg}$ \\
\hline KNO3 & 59.0 & $\mathrm{~kg}$ \\
\hline $\mathrm{Mn}(\mathrm{OH}) 2$ & 2300.0 & $\mathrm{~kg}$ \\
\hline $\mathrm{NaCl}$ & 140.0 & $\mathrm{~kg}$ \\
\hline NaNO3 & 240.0 & $\mathrm{~kg}$ \\
\hline $\mathrm{NaOH}$ & 320.0 & $\mathrm{~kg}$ \\
\hline $\mathrm{Ni}(\mathrm{OH}) 2$ & 1100.0 & $\mathrm{~kg}$ \\
\hline $\mathrm{PbCO} 3$ & 17.0 & $\mathrm{~kg}$ \\
\hline $\mathrm{SiO} 2$ & 690.0 & $\mathrm{~kg}$ \\
\hline $\mathrm{SrCO} 3$ & 10.0 & $\mathrm{~kg}$ \\
\hline $\mathrm{UO} 2(\mathrm{OH}) 2$ & 1400.0 & $\mathrm{~kg}$ \\
\hline $\mathrm{Pu}(\mathrm{OH}) 4$ & 2.46 & $\mathrm{~kg}$ \\
\hline
\end{tabular}

Figure 5-2 Input Screen for Hypothetical Worst Case Sludge 
The white background cells under inflow are manually entered, whereas, the green, Stream amount is automatically calculated by OLI Stream Analyzer ${ }^{\odot}$. The "Output" (not shown) estimates the mass of the solids as $14,523 \mathrm{~kg}$ having a volume of 5,678 liters.

Literature (Adu-Wusu, 2003, p70) recommends that 8 wt\% of a 20:1 volume ratio be added to result in $70 \mathrm{vol} \%$ of the sludge heel dissolved. The input screen for the amount of acid is shown in Figure 5-3.

\begin{tabular}{|c|c|c|}
\hline Variable & Value & Unit \\
\hline \multicolumn{3}{|c|}{ Stream Parameters } \\
\hline Stream Amt - Total Inflow & $3.80217 e 5$ & $\mathrm{~kg}$ \\
\hline Temperature & 50.0 & ${ }^{\circ} \mathrm{C}$ \\
\hline Pressure & 1.0 & atrn \\
\hline \multicolumn{3}{|c|}{ Inflows } \\
\hline $\mathrm{H} 2 \mathrm{O}$ & $3.498 \mathrm{e} 5$ & $\mathrm{~kg}$ \\
\hline $\mathrm{C} 2 \mathrm{H} 2 \mathrm{O} 4$ & 30417.0 & $\mathrm{~kg}$ \\
\hline
\end{tabular}

Figure 5-3 Input Screen for Recommended Amount of Acid for First Strike

Through trial and error, enough $8 \mathrm{wt} \%$ oxalic acid solution is added to dissolve 70 vol\% of the 5,678 liters and result in approximately 1,703 liters. This value is MAcid1. MAcid1 equals 0.418 multiplied by the literature recommended amount of acid. In Figure 5-4, the literature recommended amount of acid is put into the model with a ratio of 0.418 to equal $M_{A c i d 1}$, while $M_{E x c 1}$ equals 0.582 multiplied by the literature recommended amount of acid. The input screen to the first strike is shown in Figure $5-4$. 


\begin{tabular}{|c|c|c|c|c|}
\hline Variable & HWCS* & 1st acid 20:1* & Sum2 & Unit \\
\hline \multicolumn{5}{|c|}{ Mix Parameters } \\
\hline Ratio & 1.0 & Q & & -- \\
\hline Proportion & 0.705219 & : & 1.0 & -- \\
\hline \multicolumn{5}{|c|}{ Stream Parameters } \\
\hline Stream A.mt - Total I & 27769.5 & $\quad 3.80217 \mathrm{e} 5$ & $1.867 e 5$ & $\mathrm{~kg}$ \\
\hline Temperature & 50.0 & $\because \quad 250$ & 50.0 & ${ }^{\circ} \mathrm{C}$ \\
\hline Pressure & 1.0 & 10 & 1.0 & atrm \\
\hline \multicolumn{5}{|c|}{ Inflows } \\
\hline $\mathrm{H} 2 \mathrm{O}$ & 13247.0 & 3.49805 & $1.59463 \mathrm{e} 5$ & $\mathrm{~kg}$ \\
\hline $\mathrm{AgOH}$ & 24.0 & 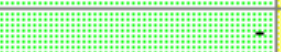 & 24.0 & $\mathrm{~kg}$ \\
\hline Al(OH)3 & 3200.0 & -4 & 3200.0 & $\mathrm{~kg}$ \\
\hline $\mathrm{CaC}_{2} \mathrm{O} 4$ & 150.0 & 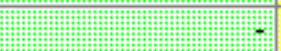 & 150.0 & $\mathrm{~kg}$ \\
\hline $\mathrm{CaCO} 3$ & 420.0 & $=$ & 420.0 & $\mathrm{~kg}$ \\
\hline $\mathrm{Fe}(\mathrm{OH}) 3$ & 4200.0 & 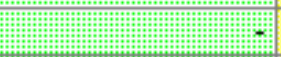 & 4200.0 & $\mathrm{~kg}$ \\
\hline $\mathrm{HgO}$ & 250.0 & -1 & 250.0 & $\mathrm{~kg}$ \\
\hline KNO3 & 59.0 & $\because$ & 59.0 & $\mathrm{~kg}$ \\
\hline $\mathrm{Mn}(\mathrm{OH}) 2$ & 2300.0 & $=$ & 2300.0 & $\mathrm{~kg}$ \\
\hline $\mathrm{NaCl}$ & 140.0 & $=$ & 140.0 & $\mathrm{~kg}$ \\
\hline NaNO3 & 240.0 & -1 & 240.0 & $\mathrm{~kg}$ \\
\hline $\mathrm{NaOH}$ & 320.0 & + & 320.0 & $\mathrm{~kg}$ \\
\hline $\mathrm{Ni}(\mathrm{OH}) 2$ & 1100.0 & $=$ & 1100.0 & $\mathrm{~kg}$ \\
\hline $\mathrm{PbCO} 3$ & 17.0 & + & 17.0 & $\mathrm{~kg}$ \\
\hline $\mathrm{SiO} 2$ & 690.0 & -1 & 690.0 & $\mathrm{~kg}$ \\
\hline $\mathrm{SrCO} 3$ & 10.0 & $=$ & 10.0 & $\mathrm{~kg}$ \\
\hline $\mathrm{UO} 2(\mathrm{OH}) 2$ & 1400.0 & -1 & 1400.0 & $\mathrm{~kg}$ \\
\hline $\mathrm{Pu}(\mathrm{OH}) 4$ & 2.46 & 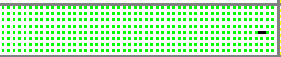 & 2.46 & $\mathrm{~kg}$ \\
\hline $\mathrm{C} 2 \mathrm{H} 2 \mathrm{O} 4$ & 0.0 & 304170 & 12714.3 & $\mathrm{~kg}$ \\
\hline
\end{tabular}

Figure 5-4 Input Screen for First Acid Strike

The output from the first strike is shown in Table 5-7. 
Table 5-7 Output from the First Acid Strike

\begin{tabular}{|c|c|c|c|c|}
\hline \multirow[t]{2}{*}{ Constituents } & $\begin{array}{c}\text { Aqueous } \\
\left(\mathrm{M}_{\mathrm{Aq} 1}\right)\end{array}$ & $\begin{array}{c}\text { Excess Acid } \\
\left(M_{\text {Exc1 }}\right)\end{array}$ & $\begin{array}{c}\text { Vapor } \\
\text { (MVap1) }\end{array}$ & $\begin{array}{c}\text { Solid } \\
\text { (MSludge2) }\end{array}$ \\
\hline & \multicolumn{4}{|c|}{$(\mathbf{k g})$} \\
\hline $\mathrm{H}_{2} \mathrm{O}$ & $1.63 E+5$ & $=0.582 \times 3.5 \mathrm{E}+5$ & $4.47 E+0$ & $0.00 \mathrm{E}+0$ \\
\hline $\mathrm{Al}(\mathrm{OH})_{3}$ & $0.00 \mathrm{E}+0$ & 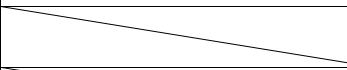 & $0.00 \mathrm{E}+0$ & $1.63 E+3$ \\
\hline $\mathrm{CaC}_{2} \mathrm{O}_{4}$ & $3.62 E+2$ & & $0.00 E+0$ & $0.00 \mathrm{E}+0$ \\
\hline $\mathrm{SiO}_{2}$ & $2.68 \mathrm{E}+1$ & - & $0.00 E+0$ & $6.63 E+2$ \\
\hline $\mathrm{Pu}(\mathrm{OH})_{4}$ & $0.00 \mathrm{E}+0$ & 25 & $0.00 E+0$ & $2.33 E+0$ \\
\hline $\mathrm{C}_{2} \mathrm{H}_{2} \mathrm{O}_{4}$ & $2.48 \mathrm{E}+3$ & $=0.582 \times 3.04 \mathrm{E}+5$ & $0.00 E+0$ & $0.00 E+0$ \\
\hline $\mathrm{Ag}_{2} \mathrm{C}_{2} \mathrm{O}_{4}$ & $3.61 \mathrm{E}-1$ & 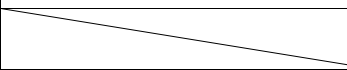 & $0.00 E+0$ & $0.00 E+0$ \\
\hline $\mathrm{AgCl}$ & $0.00 \mathrm{E}+0$ & -2 & $0.00 E+0$ & $2.72 \mathrm{E}+1$ \\
\hline $\mathrm{Al}\left(\mathrm{NO}_{3}\right)_{3}$ & $2.42 \mathrm{E}+2$ & $n^{2}$ & $0.00 \mathrm{E}+0$ & $0.00 \mathrm{E}+0$ \\
\hline $\mathrm{AlCl}_{3}$ & $9.80 \mathrm{E}+1$ & +2 & $0.00 \mathrm{E}+0$ & $0.00 \mathrm{E}+0$ \\
\hline $\mathrm{CaC}_{2} \mathrm{O}_{4} \cdot 1 \mathrm{H}_{2} \mathrm{O}$ & $1.10 \mathrm{E}+3$ & $-e^{2}$ & $0.00 \mathrm{E}+0$ & $0.00 \mathrm{E}+0$ \\
\hline $\mathrm{CO}_{2}$ & $0.00 \mathrm{E}+0$ & $x_{2}$ & $0.00 \mathrm{E}+0$ & $3.72 \mathrm{E}+2$ \\
\hline $\mathrm{Fe}_{2}\left(\mathrm{C}_{2} \mathrm{O}_{4}\right)_{3}$ & $1.13 E+2$ & $x^{2}$ & $7.79 \mathrm{E}+1$ & $0.00 E+0$ \\
\hline $\mathrm{HCl}$ & $7.38 \mathrm{E}+3$ & 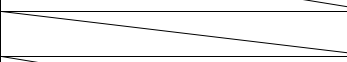 & $0.00 \mathrm{E}+0$ & $0.00 \mathrm{E}+0$ \\
\hline $\mathrm{HgC}_{2} \mathrm{O}_{4}$ & $0.00 \mathrm{E}+0$ & -2 & $9.81 \mathrm{E}-11$ & $0.00 \mathrm{E}+0$ \\
\hline $\mathrm{HgCl}_{2}$ & $3.33 E+2$ & -2 & $0.00 \mathrm{E}+0$ & $0.00 \mathrm{E}+0$ \\
\hline $\mathrm{HNO}_{3}$ & $0.00 \mathrm{E}+0$ & -2 & $7.45 \mathrm{E}-5$ & $0.00 E+0$ \\
\hline $\mathrm{K}_{2} \mathrm{C}_{2} \mathrm{O}_{4}$ & $0.00 \mathrm{E}+0$ & -2 & $8.19 \mathrm{E}-9$ & $0.00 \mathrm{E}+0$ \\
\hline $\mathrm{MnC}_{2} \mathrm{O}_{4}$ & $4.85 \mathrm{E}+1$ & 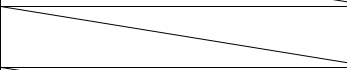 & $0.00 \mathrm{E}+0$ & $0.00 \mathrm{E}+0$ \\
\hline $\mathrm{MnC}_{2} \mathrm{O}_{4} .2 \mathrm{H}_{2} \mathrm{O}$ & $2.59 \mathrm{E}+2$ & $y^{2}$ & $0.00 \mathrm{E}+0$ & $0.00 \mathrm{E}+0$ \\
\hline $\mathrm{Na}_{2} \mathrm{C}_{2} \mathrm{O}_{4}$ & $0.00 E+0$ & 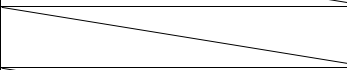 & $0.00 E+0$ & $4.30 E+3$ \\
\hline $\mathrm{NaAlO}_{2}$ & $8.86 \mathrm{E}+2$ & 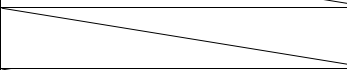 & $0.00 E+0$ & $0.00 E+0$ \\
\hline $\mathrm{NiC}_{2} \mathrm{O}_{4}$ & $7.44 \mathrm{E}+0$ & -2 & $0.00 E+0$ & $1.73 E+3$ \\
\hline $\mathrm{PbC}_{2} \mathrm{O}_{4}$ & $1.88 \mathrm{E}+1$ & $n^{2}$ & $0.00 \mathrm{E}+0$ & $0.00 \mathrm{E}+0$ \\
\hline $\mathrm{Pu}\left(\mathrm{C}_{2} \mathrm{O}_{4}\right)_{2}$ & $1.76 \mathrm{E}-1$ & $x^{2}$ & $0.00 E+0$ & $0.00 E+0$ \\
\hline $\mathrm{SiCl}_{4}$ & $0.00 \mathrm{E}+0$ & $x^{2}$ & $0.00 \mathrm{E}+0$ & $0.00 \mathrm{E}+0$ \\
\hline $\mathrm{SrC}_{2} \mathrm{O}_{4}$ & $1.19 \mathrm{E}+1$ & 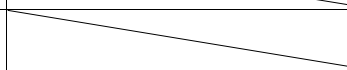 & $0.00 \mathrm{E}+0$ & $0.00 E+0$ \\
\hline $\mathrm{UO}_{2} \mathrm{C}_{2} \mathrm{O}_{4}$ & $1.65 \mathrm{E}+3$ & $e^{2}$ & $0.00 \mathrm{E}+0$ & $0.00 \mathrm{E}+0$ \\
\hline
\end{tabular}

$M_{\text {Exc1 }}$ must be hand calculated since it was restricted from the input in order to keep it from reacting within the treatment tank. The aqueous, $\mathrm{M}_{\mathrm{Aq}}$, and excess acid, MExc1, from the first strike are transferred to the adjustment tank, while the vapor 
MVap1 is released to the atmosphere. The sludge solids, Msludge2 remain in the treatment tank. After dissolution, the remaining sludge may be flushed. Flushing will lower the ionic strength of the remaining interstitial solution within the treatment tank. The interstitial liquid, however, is not considered significant within the model, since the volume is very small compared to the amount of acid solution to be added. Solids are assumed not to carry over. Spent acid/dissolved sludge and unspent acid, MAq1, MExc1 are transferred to the $\mathrm{pH}$ adjustment tank, with the solids remaining. The software's capability to separate each phase is used to separate the liquid fraction from the solids, and the solids become input to the second strike. Refer to Figure 5-5.

\begin{tabular}{|c|c|c|}
\hline Stream Amt - Total nitlow & 872765 & $\mathrm{~kg}$ \\
\hline Temperature & 50.0 & ${ }^{\circ} \mathrm{C}$ \\
\hline Pressure & 1.0 & atm \\
\hline \multicolumn{3}{|c|}{ Inflows } \\
\hline $\mathrm{H} 2 \mathrm{O}$ & 0.0 & $\mathrm{~kg}$ \\
\hline $\mathrm{AgCl}$ & 27.2047 & $\mathrm{~kg}$ \\
\hline $\mathrm{Al}(\mathrm{OH}) 3$ & 1625.73 & $\mathrm{~kg}$ \\
\hline $\mathrm{CaC} 2 \mathrm{O} 4.1 \mathrm{H} 2 \mathrm{O}$ & 371.774 & $\mathrm{~kg}$ \\
\hline $\mathrm{MnC} 2 \mathrm{O} 4.2 \mathrm{H} 2 \mathrm{O}$ & 4303.88 & $\mathrm{~kg}$ \\
\hline $\mathrm{NiC2O4}$ & 1733.5 & $\mathrm{~kg}$ \\
\hline $\mathrm{Pu}(\mathrm{OH}) 4$ & 2.32927 & $\mathrm{~kg}$ \\
\hline $\mathrm{SiO} 2$ & 663.238 & $\mathrm{~kg}$ \\
\hline
\end{tabular}

Figure 5-5 Screen for Solids after First Acid Strike

The literature recommended amount of $8 \mathrm{wt} \%$ oxalic acid solution, to result in a 50 vol\% dissolution for the second strike, is a 0.3 fraction of the initial acid. Using trial and error, it is determined that only 0.3 of the initial 0.3 fraction is required for the model to dissolve 50 vol\% of the sludge; therefore, $M_{\text {Acid2 }}=0.3 \times 0.3 \times M_{\text {Acid1 }}$. Refer to Figure 5-6. 


\begin{tabular}{|c|c|c|c|c|}
\hline Variable & sludge $2^{*}$ & Acid $^{*}$ & Sum2 & Unit \\
\hline \multicolumn{5}{|c|}{ Mix Parameters } \\
\hline Ratio & 10 & 0.09 & & -- \\
\hline Proportion & 0.917431 & 0.0825688 & 1.0 & -- \\
\hline \multicolumn{5}{|c|}{ Stream Parameters } \\
\hline Stream Arnt - & 101230 & $3.80217 \mathrm{es}$ & 44342.5 & $\mathrm{~kg}$ \\
\hline Temperature & $\quad 250$ & 25.0 & 25.0 & ${ }^{\circ} \mathrm{C}$ \\
\hline Pressure & 10 & 1.0 & 1.0 & atm \\
\hline \multicolumn{5}{|c|}{ Inflows } \\
\hline $\mathrm{H} 2 \mathrm{O}$ & 00 & $3.498 \mathrm{e} 5$ & 31482.0 & $\mathrm{~kg}$ \\
\hline $\mathrm{AgCl}$ & $27 \times 4607$ & - & 27.4607 & $\mathrm{~kg}$ \\
\hline $\mathrm{Al}(\mathrm{OH}) 3$ & 1763.31 & - & 1763.31 & $\mathrm{~kg}$ \\
\hline $\mathrm{CaC} 2 \mathrm{O} 4.1 \mathrm{H} 2$ & $580 \times 136$ & - & 580.136 & $\mathrm{~kg}$ \\
\hline $\mathrm{MnC} 2 \mathrm{O} 4.2 \mathrm{H} 2$ & 444306 & - & 4443.06 & $\mathrm{~kg}$ \\
\hline $\mathrm{NiC} 2 \mathrm{O} 4.2 \mathrm{H} 2 \mathrm{O}$ & $2162 \times 7$ & - & 2162.77 & $\mathrm{~kg}$ \\
\hline $\mathrm{PbC} 2 \mathrm{O} 4$ & 8.03733 & - & 8.83733 & $\mathrm{~kg}$ \\
\hline $\mathrm{Pu}(\mathrm{OH}) 4$ & 240663 & - & 2.40663 & $\mathrm{~kg}$ \\
\hline $\mathrm{SiO} 2$ & 673014 & - & 673.011 & $\mathrm{~kg}$ \\
\hline $\mathrm{UO} 2 \mathrm{C} 2 \mathrm{O} 4.3 \mathrm{H}$ & 461.977 & - & 461.977 & $\mathrm{~kg}$ \\
\hline $\mathrm{C} 2 \mathrm{H} 2 \mathrm{O} 4$ & $\quad 00$ & 30417.0 & 2737.53 & $\mathrm{~kg}$ \\
\hline
\end{tabular}

Figure 5-6 Input Screen for Second Acid Strike

MExc2 is based on (10.3) multiplied by the initial acid required [Badheka, 2003:121].

Table 5-8 shows the output of the second acid strike, where $M_{E x c 2}$ is excess and must be hand entered, so as not to react until reaching the $\mathrm{pH}$ adjustment tank. 
Table 5-8 Output from the Second Acid Strike

\begin{tabular}{|cc|c|c|c|}
\hline Constituents & $\begin{array}{c}\text { Aqueous } \\
\left(\mathbf{M}_{\text {Aq2 }}\right)\end{array}$ & $\begin{array}{c}\text { Excess Acid } \\
\text { (MExc2) }\end{array}$ & $\begin{array}{c}\text { Vapor } \\
\text { (MVap2) }\end{array}$ & $\begin{array}{c}\text { Solid } \\
\text { (MSludge3) }\end{array}$ \\
\cline { 2 - 5 } & \multicolumn{2}{|c|}{$\mathbf{( k g )}$} \\
$\mathrm{H}_{2} \mathrm{O}$ & $3.17 \mathrm{E}+4$ & $=0.7 \times 1.05 \mathrm{E}+5$ & $0.00 \mathrm{E}+0$ & $0.00 \mathrm{E}+0$ \\
\hline $\mathrm{AgCl}$ & $4.24 \mathrm{E}-1$ & & $0.00 \mathrm{E}+0$ & $2.68 \mathrm{E}+1$ \\
\hline $\mathrm{Al}(\mathrm{OH})_{3}$ & $0.00 \mathrm{E}+0$ & & $0.00 \mathrm{E}+0$ & $1.78 \mathrm{E}+2$ \\
$\mathrm{CaC}_{2} \mathrm{O}_{4} \cdot 1 \mathrm{H}_{2} \mathrm{O}$ & $0.00 \mathrm{E}+0$ & & $0.00 \mathrm{E}+0$ & $3.72 \mathrm{E}+2$ \\
\hline $\mathrm{MnC}_{2} \mathrm{O}_{4} \cdot 2 \mathrm{H}_{2} \mathrm{O}$ & $0.00 \mathrm{E}+0$ & & $0.00 \mathrm{E}+0$ & $2.89 \mathrm{E}+3$ \\
\hline $\mathrm{NiC}_{2} \mathrm{O}_{4}$ & $1.19 \mathrm{E}+0$ & & $0.00 \mathrm{E}+0$ & $0.00 \mathrm{E}+0$ \\
\hline $\mathrm{SiO}_{2}$ & $2.66 \mathrm{E}+0$ & & $0.00 \mathrm{E}+0$ & $6.61 \mathrm{E}+2$ \\
\hline $\mathrm{C}_{2} \mathrm{H}_{2} \mathrm{O}_{4}$ & $2.74 \mathrm{E}+3$ & $=0.7 \times 9125.1$ & $0.00 \mathrm{E}+0$ & $0.00 \mathrm{E}+0$ \\
\hline $\mathrm{AlO}_{4}(\mathrm{OH})$ & $1.11 \mathrm{E}+3$ & & $0.00 \mathrm{E}+0$ & $0.00 \mathrm{E}+0$ \\
\hline $\mathrm{CaC}_{2} \mathrm{O}_{4}$ & $3.44 \mathrm{E}-2$ & & $0.00 \mathrm{E}+0$ & $0.00 \mathrm{E}+0$ \\
\hline $\mathrm{MnC}_{2} \mathrm{O}_{4}$ & $1.13 \mathrm{E}+3$ & & $0.00 \mathrm{E}+0$ & $0.00 \mathrm{E}+0$ \\
\hline $\mathrm{Pu}_{2}\left(\mathrm{C}_{2} \mathrm{O}_{4}\right)_{2}$ & $0.00 \mathrm{E}+0$ & & $0.00 \mathrm{E}+0$ & $2.16 \mathrm{E}+3$ \\
\hline
\end{tabular}

After the second acid strike, the aqueous and excess acid solutions are transferred to the $\mathrm{pH}$ adjustment tank, and the vapor is released into the atmosphere. The solids remain within the treatment tank. The interstitial liquid, although 70 vol\% of

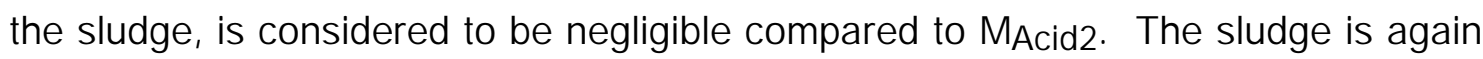
treated with oxalic acid.

The third strike of oxalic acid is estimated to dissolve $30 \mathrm{vol} \%$ of the sludge. This time Adu-Wusu [2003:70] recommended amount of $8 w t \%$ oxalic acid is equal to that required based on modeling trials. $M_{A c i d 3}$ is expressed in terms of $M_{A c i d 1}$ for convenience. The input for the third strike is shown in Figure 5-7. 


\begin{tabular}{|c|c|c|c|c|}
\hline Variable & $50 \%$ dissolved solids & 1st acid 20:1* & Sum2 & Unit \\
\hline \multicolumn{5}{|c|}{ Mix Parameters } \\
\hline Ratio & 10 & 0.15 & & --- \\
\hline Proportion & 0.869565 & 0.130435 & 1.0 & $\cdots$ \\
\hline \multicolumn{5}{|c|}{ Stream Parameters } \\
\hline Stream Arnt - Total I & 6288.93 & $3.80217 \mathrm{e} 5$ & 63321.5 & $\mathrm{~kg}$ \\
\hline Temperature & 250 & 25.0 & 25.0 & ${ }^{\circ} \mathrm{C}$ \\
\hline Pressure & 10 & 1.0 & 1.0 & atm \\
\hline \multicolumn{5}{|c|}{ Inflows } \\
\hline $\mathrm{H} 2 \mathrm{O}$ & 0.0 & $3.498 \mathrm{e}$ & 52470.0 & $\mathrm{~kg}$ \\
\hline $\mathrm{AgCl}$ & 26.7805 & - & 26.7805 & $\mathrm{~kg}$ \\
\hline Al( $(\mathrm{OH}) 3$ & 177.55 & - & 177.55 & $\mathrm{~kg}$ \\
\hline $\mathrm{CaC} 2 \mathrm{O} 4.1 \mathrm{H} 2 \mathrm{O}$ & 371.735 & - & 371.735 & $\mathrm{~kg}$ \\
\hline MnC2O4.2H2O & 2894.48 & - & 2894.48 & $\mathrm{~kg}$ \\
\hline $\mathrm{NiC} 2 \mathrm{O} 4.2 \mathrm{H} 2 \mathrm{O}$ & 2157.8 & - & 2157.8 & $\mathrm{~kg}$ \\
\hline $\mathrm{SiO} 2$ & 660.579 & - & 660.579 & $\mathrm{~kg}$ \\
\hline $\mathrm{C} 2 \mathrm{H} 2 \mathrm{O} 4$ & 00 & 30417.0 & 4562.55 & $\mathrm{~kg}$ \\
\hline
\end{tabular}

Figure 5-7 Input Screen for Third Acid Strike

The output from the third strike and the excess acid are shown in Table 5-9.

Table 5-9 Output from the Third Acid Strike

\begin{tabular}{|c|c|c|c|c|}
\hline \multirow{3}{*}{ Constituents } & Aqueous & Excess Acid & Vapor & Solid \\
\hline & $M_{A q 3}$ & MExc3 & MVap3 & MSludge4 \\
\hline & \multicolumn{4}{|c|}{ (kg) } \\
\hline $\mathrm{H}_{2} \mathrm{O}$ & $5.25 \mathrm{E}+4$ & $=0.15 \times 3.8 \mathrm{E}+5$ & $0.00 \mathrm{E}+0$ & $0.00 E+0$ \\
\hline $\mathrm{AgCl}$ & $1.75 \mathrm{E}-1$ & 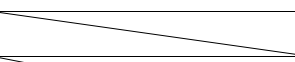 & $0.00 \mathrm{E}+0$ & $2.66 \mathrm{E}+1$ \\
\hline $\mathrm{CaC}_{2} \mathrm{O}_{4} \cdot 1 \mathrm{H}_{2} \mathrm{O}$ & $0.00 \mathrm{E}+0$ & $n_{-2}$ & $0.00 \mathrm{E}+0$ & $3.65 E+2$ \\
\hline $\mathrm{MnC}_{2} \mathrm{O}_{4} .2 \mathrm{H}_{2} \mathrm{O}$ & $0.00 \mathrm{E}+0$ & $x^{2}$ & $0.00 \mathrm{E}+0$ & $2.87 E+3$ \\
\hline $\mathrm{NiC}_{2} \mathrm{O}_{4} \cdot 2 \mathrm{H}_{2} \mathrm{O}$ & $0.00 \mathrm{E}+0$ & $y_{-2}$ & $0.00 \mathrm{E}+0$ & $2.16 \mathrm{E}+3$ \\
\hline $\mathrm{SiO}_{2}$ & $5.97 \mathrm{E}+0$ & 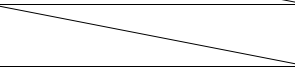 & $0.00 \mathrm{E}+0$ & $6.55 E+2$ \\
\hline $\mathrm{C}_{2} \mathrm{H}_{2} \mathrm{O}_{4}$ & $4.56 \mathrm{E}+3$ & $=0.15 \times 3.0 \mathrm{E}+4$ & $0.00 \mathrm{E}+0$ & $0.00 \mathrm{E}+0$ \\
\hline $\mathrm{AlO}(\mathrm{OH})$ & $1.37 \mathrm{E}+2$ & 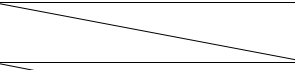 & $0.00 \mathrm{E}+0$ & $0.00 \mathrm{E}+0$ \\
\hline $\mathrm{CaC}_{2} \mathrm{O}_{4}$ & $6.31 E+0$ & 2 & $0.00 \mathrm{E}+0$ & $0.00 \mathrm{E}+0$ \\
\hline $\mathrm{MnC}_{2} \mathrm{O}_{4}$ & $1.69 \mathrm{E}+1$ & -3 & $0.00 \mathrm{E}+0$ & $0.00 \mathrm{E}+0$ \\
\hline $\mathrm{NiC}_{2} \mathrm{O}_{4}$ & $1.48 \mathrm{E}+0$ & -2 & $0.00 \mathrm{E}+0$ & $0.00 \mathrm{E}+0$ \\
\hline
\end{tabular}


Again, the aqueous and excess acid is transferred out, the vapor is released to the atmosphere, and $6,076 \mathrm{~kg}$ of solids remain. Since $70-50-30$ vol\% is assumed to be dissolved, the sludge heel in the treatment tank decreased from a volume of 5,000 gallons to a resulting volume of 525 gallons or 1,987 liters.

The $\mathrm{pH}$ adjustment tank is assumed to initially contain 100,000 gallons of supernate and is pre-charged with caustic to ensure that it will remain within the corrosion control program. The input to the $\mathrm{pH}$ adjustment tank is shown in Figure 5-8.

\begin{tabular}{|c|c|c|c|c|}
\hline Variable & Supernate $^{\star}$ & truck of caustic $^{t}$ & Sum2 & Unit \\
\hline \multicolumn{5}{|c|}{ Mix Parameters } \\
\hline Ratio & 20 & 5.8 & & -- \\
\hline Proportion & 0.25641 & 0.74359 & 1.0 & -- \\
\hline \multicolumn{5}{|c|}{ Stream Parameters } \\
\hline Stream A.nnt - & 409853 & 22712.4 & $2.13702 \mathrm{e} 5$ & $\mathrm{~kg}$ \\
\hline Temperature & 250 & 25.0 & 25.0 & ${ }^{\circ} \mathrm{C}$ \\
\hline Pressure & 10 & 1.0 & 1.0 & atrm \\
\hline \multicolumn{5}{|c|}{ Calc Parameters } \\
\hline Known: Delta & - & 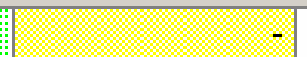 & 0.0 & kcal \\
\hline \multicolumn{5}{|c|}{ Inflows } \\
\hline $\mathrm{H} 2 \mathrm{O}$ & 189270 & 11356.2 & $1.0372 \mathrm{e} 5$ & $\mathrm{~kg}$ \\
\hline $\mathrm{HgC} 2 \mathrm{O} 4$ & $\quad 18 \times$ & - & 37.4 & $\mathrm{~kg}$ \\
\hline $\mathrm{HNO} 2$ & 27000 & - & 5400.0 & $\mathrm{~kg}$ \\
\hline $\mathrm{AgOH}$ & 1874 & - & 3.48 & $\mathrm{~kg}$ \\
\hline $\mathrm{Al}(\mathrm{OH}) 3$ & 55000 & - & 11000.0 & $\mathrm{~kg}$ \\
\hline $\mathrm{Na} 2 \mathrm{CO} 3$ & 8190 & - & 1638.0 & $\mathrm{~kg}$ \\
\hline $\mathrm{Fe}(\mathrm{OH}) 3$ & 101 & - & 2.02 & $\mathrm{~kg}$ \\
\hline $\mathrm{HgO}$ & $7 \times 7$ & - & 15.4 & $\mathrm{~kg}$ \\
\hline $\mathrm{Mn}(\mathrm{OH}) 2$ & $2.61 e-2$ & - & 0.0522 & $\mathrm{~kg}$ \\
\hline $\mathrm{Ni}(\mathrm{OH}) 2$ & $906 \mathrm{e}-2$ & - & 0.1812 & $\mathrm{~kg}$ \\
\hline NaNO3 & 97600 & - & 19520.0 & $\mathrm{~kg}$ \\
\hline $\mathrm{NaOH}$ & 325000 & 11356.2 & 72366.0 & $\mathrm{~kg}$ \\
\hline
\end{tabular}

Figure 5-8 Input Screen to pH Adjustment in Adjustment Tank

The output from the addition of caustic to spent/excess acid is shown in Table 5-10. 
Table 5-10 pH Adjustment with Supernate Add to Spent/Excess Acid

\begin{tabular}{|c|c|c|c|}
\hline \multirow{2}{*}{ Constituents } & Aqueous & \multicolumn{1}{|c|}{ Vapor } & Solid \\
\cline { 2 - 4 } & \multicolumn{3}{|c|}{$(\mathbf{k g})$} \\
\hline $\mathrm{H}_{2} \mathrm{O}$ & $1.11 \mathrm{E}+5$ & $0.00 \mathrm{E}+0$ & $0.00 \mathrm{E}+0$ \\
\hline $\mathrm{AgOH}$ & $3.48 \mathrm{E}+0$ & $0.00 \mathrm{E}+0$ & $0.00 \mathrm{E}+0$ \\
\hline $\mathrm{Na} 2 \mathrm{CO}_{3}$ & $1.64 \mathrm{E}+3$ & $0.00 \mathrm{E}+0$ & $0.00 \mathrm{E}+0$ \\
\hline $\mathrm{Fe}(\mathrm{OH})_{3}$ & $2.02 \mathrm{E}+0$ & $0.00 \mathrm{E}+0$ & $0.00 \mathrm{E}+0$ \\
\hline $\mathrm{HgO}$ & $4.35 \mathrm{E}+1$ & $0.00 \mathrm{E}+0$ & $0.00 \mathrm{E}+0$ \\
\hline $\mathrm{Mn}(\mathrm{OH})_{2}$ & $5.22 \mathrm{E}-2$ & $0.00 \mathrm{E}+0$ & $0.00 \mathrm{E}+0$ \\
\hline $\mathrm{Ni}(\mathrm{OH})_{2}$ & $1.81 \mathrm{E}-1$ & $0.00 \mathrm{E}+0$ & $0.00 \mathrm{E}+0$ \\
\hline $\mathrm{NaNO}$ & $1.86 \mathrm{E}+4$ & $0.00 \mathrm{E}+0$ & $8.73 \mathrm{E}+2$ \\
\hline $\mathrm{NaOH}$ & $6.21 \mathrm{E}+4$ & $0.00 \mathrm{E}+0$ & $0.00 \mathrm{E}+0$ \\
\hline $\mathrm{Na} \mathrm{C}_{2} \mathrm{O}_{4}$ & $8.18 \mathrm{E}-1$ & $0.00 \mathrm{E}+0$ & $1.65 \mathrm{E}+1$ \\
\hline $\mathrm{NaAlO}_{2}$ & $1.16 \mathrm{E}+4$ & $0.00 \mathrm{E}+0$ & $0.00 \mathrm{E}+0$ \\
\hline $\mathrm{NaNO}_{2}$ & $7.92 \mathrm{E}+3$ & $0.00 \mathrm{E}+0$ & $0.00 \mathrm{E}+0$ \\
\hline
\end{tabular}

$M_{A q 1}$ and $M_{E x c 1}$ are added to the adjustment tank as shown in Figure 5-9. $M_{E x c 1}$ is calculated based on $M_{A c i d 1}+M_{E x c 1}=$ Recommended amount of acid to be added based on literature. 


\begin{tabular}{|c|c|c|c|c|c|}
\hline Variable & pre-charg & Aq1* & Acid* & Sum2 & Unit \\
\hline \multicolumn{6}{|c|}{ Mix Parameters } \\
\hline Ratio & 10 & 1.0 & 0.59 & & -- \\
\hline Proportion & 0.3861 & 0.3861 & 0.227799 & 1.0 & -- \\
\hline \multicolumn{6}{|c|}{ Stream Parameters } \\
\hline Stream Arnt - & $2.13702=5$ & $1.73536 \mathrm{es}$ & $3.80217 \mathrm{e} 5$ & $6.11566 \mathrm{e} 5$ & $\mathrm{~kg}$ \\
\hline Temperature & $\because \quad 250$ & 25.0 & 25.0 & 25.0 & ${ }^{\circ} \mathrm{C}$ \\
\hline Pressure & 10 & 1.0 & 1.0 & 1.0 & atrm \\
\hline \multicolumn{6}{|c|}{ Inflows } \\
\hline $\mathrm{H} 2 \mathrm{O}$ & 1037285 & $1.59507 e 5$ & $3.498 \mathrm{e} 5$ & $4.69609 e 5$ & $\mathrm{~kg}$ \\
\hline $\mathrm{HgC2O} 4$ & $=374$ & 333.133 & - & 370.533 & $\mathrm{~kg}$ \\
\hline $\mathrm{HNO} 2$ & 54000 & - & - & 5400.0 & $\mathrm{~kg}$ \\
\hline $\mathrm{AgOH}$ & 348 & 0.0 & - & 3.48 & $\mathrm{~kg}$ \\
\hline $\mathrm{Al}(\mathrm{OH}) 3$ & 110000 & 0.0 & - & 11000.0 & $\mathrm{~kg}$ \\
\hline $\mathrm{Na} 2 \mathrm{CO} 3$ & 16380 & 0.0 & - & 1638.0 & $\mathrm{~kg}$ \\
\hline $\mathrm{Fe}(\mathrm{OH}) 3$ & 202 & 0.0 & - & 2.02 & $\mathrm{~kg}$ \\
\hline $\mathrm{HgO}$ & 154 & 0.0 & - & 15.4 & $\mathrm{~kg}$ \\
\hline $\mathrm{M} \cap(\mathrm{OH}) 2$ & 00522 & 0.0 & - & 0.0522 & $\mathrm{~kg}$ \\
\hline $\mathrm{Ni}(\mathrm{OH}) 2$ & 0.1812 & 0.0 & - & 0.1812 & $\mathrm{~kg}$ \\
\hline NaNO3 & 195200 & 0.0 & - & 19520.0 & $\mathrm{~kg}$ \\
\hline $\mathrm{NaOH}$ & 723660 & 0.0 & - & 72366.0 & $\mathrm{~kg}$ \\
\hline $\mathrm{AlCl} 3$ & - & 97.957 & - & 97.957 & $\mathrm{~kg}$ \\
\hline $\mathrm{CaC} 2 \mathrm{O} 4$ & 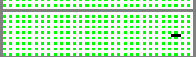 & 178.936 & - & 178.936 & $\mathrm{~kg}$ \\
\hline $\mathrm{K}_{2} \mathrm{C} 2 \mathrm{O} 4$ & - & 48.4992 & - & 48.4992 & $\mathrm{~kg}$ \\
\hline $\mathrm{PbC} 2 \mathrm{O} 4$ & $\frac{1-1}{-1}$ & 9.94479 & - & 9.94479 & $\mathrm{~kg}$ \\
\hline Pu(C2O4)2 & 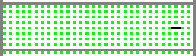 & 0.071845 & - & 0.071845 & $\mathrm{~kg}$ \\
\hline $\mathrm{SiO} 2$ & - & 16.9892 & - & 16.9892 & $\mathrm{~kg}$ \\
\hline $\mathrm{SrC}_{2} \mathrm{O} 4$ & $\frac{-1}{-1}$ & 11.8974 & - & 11.8974 & $\mathrm{~kg}$ \\
\hline $\mathrm{UO} 2 \mathrm{C} 2 \mathrm{O} 4$ & 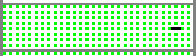 & 1247.3 & - & 1247.3 & $\mathrm{~kg}$ \\
\hline $\mathrm{Ag} 2 \mathrm{C} 2 \mathrm{O} 4$ & 00 & 0.0894298 & - & 0.0894298 & $\mathrm{~kg}$ \\
\hline Al(NO3)3 & 00 & 241.913 & - & 241.913 & $\mathrm{~kg}$ \\
\hline $\mathrm{AlO}(\mathrm{OH})$ & 00 & 992.687 & - & 992.687 & $\mathrm{~kg}$ \\
\hline $\mathrm{C} 2 \mathrm{H} 2 \mathrm{O} 4$ & 00 & 2237.15 & 30417.0 & 20183.2 & $\mathrm{~kg}$ \\
\hline $\mathrm{CO} 2$ & 00 & 190.463 & - & 190.463 & $\mathrm{~kg}$ \\
\hline $\mathrm{Fe} 2(\mathrm{C} 2 \mathrm{O} 4) 3$ & 00 & 7383.69 & - & 7383.69 & $\mathrm{~kg}$ \\
\hline $\mathrm{MnC} 2 \mathrm{O} 4$ & 00 & 147.717 & - & 147.717 & $\mathrm{~kg}$ \\
\hline $\mathrm{Na} 2 \mathrm{C} 2 \mathrm{O} 4$ & 90 & 885.727 & - & 885.727 & $\mathrm{~kg}$ \\
\hline $\mathrm{NiC2O4}$ & 00 & 4.64753 & - & 4.64753 & $\mathrm{~kg}$ \\
\hline
\end{tabular}

Figure 5-9 Input Screen of $1^{\text {st }}$ Transfer of Spent Acid to the Adjustment Tank

$M_{A q 2}$ and $M_{E x C 2}$ are added to the adjustment tank as shown in Figure 5-10. 


\begin{tabular}{|c|c|c|}
\hline Variable & Value & Unit \\
\hline \multicolumn{3}{|c|}{ Inflows } \\
\hline $\mathrm{H} 2 \mathrm{O}$ & $5.75201 \mathrm{es}$ & $\mathrm{kg}$ \\
\hline $\mathrm{HgC2O} 4$ & 370.533 & $\mathrm{~kg}$ \\
\hline $\mathrm{HNO} 2$ & 5400.0 & $\mathrm{~kg}$ \\
\hline $\mathrm{AgOH}$ & 3.48 & $\mathrm{~kg}$ \\
\hline $\mathrm{Al}(\mathrm{OH}) 3$ & 11000.0 & $\mathrm{~kg}$ \\
\hline $\mathrm{Na} 2 \mathrm{CO} 3$ & 1638.0 & $\mathrm{~kg}$ \\
\hline $\mathrm{Fe}(\mathrm{OH}) 3$ & 2.02 & $\mathrm{~kg}$ \\
\hline $\mathrm{HgO}$ & 15.4 & $\mathrm{~kg}$ \\
\hline $\mathrm{Mn}(\mathrm{OH}) 2$ & 0.0522 & $\mathrm{~kg}$ \\
\hline $\mathrm{Ni}(\mathrm{OH}) 2$ & 0.1812 & $\mathrm{~kg}$ \\
\hline NaNO3 & 19520.0 & $\mathrm{~kg}$ \\
\hline $\mathrm{NaOH}$ & 72366.0 & $\mathrm{~kg}$ \\
\hline $\mathrm{Ag} 2 \mathrm{C} 2 \mathrm{O} 4$ & 0.0894298 & $\mathrm{~kg}$ \\
\hline Al(NO3)3 & 241.913 & $\mathrm{~kg}$ \\
\hline $\mathrm{AlCl} 3$ & 97.957 & $\mathrm{~kg}$ \\
\hline $\mathrm{AlO}(\mathrm{OH})$ & 2111.03 & $\mathrm{~kg}$ \\
\hline $\mathrm{C} 2 \mathrm{H} 2 \mathrm{O} 4$ & 29306.9 & $\mathrm{~kg}$ \\
\hline $\mathrm{CaC} 2 \mathrm{O} 4$ & 178.972 & $\mathrm{~kg}$ \\
\hline $\mathrm{CO} 2$ & 190.463 & $\mathrm{~kg}$ \\
\hline $\mathrm{Fe} 2(\mathrm{C} 2 \mathrm{O} 4) 3$ & 7383.69 & $\mathrm{~kg}$ \\
\hline $\mathrm{K} 2 \mathrm{C} 2 \mathrm{O} 4$ & 48.4992 & $\mathrm{~kg}$ \\
\hline $\mathrm{MnC} 2 \mathrm{O} 4$ & 1160.31 & $\mathrm{~kg}$ \\
\hline $\mathrm{Na} 2 \mathrm{C} 2 \mathrm{O} 4$ & 885.727 & $\mathrm{~kg}$ \\
\hline $\mathrm{NiC} 2 \mathrm{O} 4$ & 5.82886 & $\mathrm{~kg}$ \\
\hline $\mathrm{PbC} 2 \mathrm{O} 4$ & 11.3911 & $\mathrm{~kg}$ \\
\hline $\mathrm{Pu}(\mathrm{C} 2 \mathrm{O} 4) 2$ & 3.31156 & $\mathrm{~kg}$ \\
\hline $\mathrm{SiO} 2$ & 19.6953 & $\mathrm{~kg}$ \\
\hline $\mathrm{SrC} 2 \mathrm{O} 4$ & 11.8974 & $\mathrm{~kg}$ \\
\hline $\mathrm{UO} 2 \mathrm{C} 2 \mathrm{O} 4$ & 1648.69 & $\mathrm{~kg}$ \\
\hline $\mathrm{AgCl}$ & 0.420371 & $\mathrm{~kg}$ \\
\hline
\end{tabular}

Figure 5-10 Input Screen of 2nd Transfer of Spent Acid to the Adjustment Tank

$\mathrm{M}_{\mathrm{Aq} 3}$ and $\mathrm{M}_{\mathrm{Exc} 3}$ are added to the adjustment tank as shown in Figure 5-11. 


\begin{tabular}{|c|c|c|}
\hline$\nabla$ & & \\
\hline $\mathrm{H} 2 \mathrm{O}$ & $6.27748 \mathrm{e} 5$ & $\mathrm{~kg}$ \\
\hline $\mathrm{HgC2O} 4$ & 370.533 & $\mathrm{~kg}$ \\
\hline $\mathrm{HNO} 2$ & 5400.0 & $\mathrm{~kg}$ \\
\hline $\mathrm{AgOH}$ & 3.48 & $\mathrm{~kg}$ \\
\hline $\mathrm{Al}(\mathrm{OH}) 3$ & 11000.0 & $\mathrm{~kg}$ \\
\hline $\mathrm{Na} 2 \mathrm{CO} 3$ & 1638.0 & $\mathrm{~kg}$ \\
\hline $\mathrm{Fe}(\mathrm{OH}) 3$ & 2.02 & $\mathrm{~kg}$ \\
\hline $\mathrm{HgO}$ & 15.4 & $\mathrm{~kg}$ \\
\hline $\mathrm{M} n(\mathrm{OH}) 2$ & 0.0522 & $\mathrm{~kg}$ \\
\hline $\mathrm{Ni}(\mathrm{OH}) 2$ & 0.1812 & $\mathrm{~kg}$ \\
\hline NaNO3 & 19520.0 & $\mathrm{~kg}$ \\
\hline $\mathrm{NaOH}$ & 72366.0 & $\mathrm{~kg}$ \\
\hline $\mathrm{Ag} 2 \mathrm{C} 2 \mathrm{O} 4$ & 0.0894298 & $\mathrm{~kg}$ \\
\hline Al(NO3)3 & 241.913 & $\mathrm{~kg}$ \\
\hline $\mathrm{AlCl} 3$ & 97.957 & $\mathrm{~kg}$ \\
\hline $\mathrm{AlO}(\mathrm{OH})$ & 2348.76 & $\mathrm{~kg}$ \\
\hline $\mathrm{C} 2 \mathrm{H} 2 \mathrm{O} 4$ & 33869.5 & $\mathrm{~kg}$ \\
\hline $\mathrm{CaC} 2 \mathrm{O} 4$ & 184.433 & $\mathrm{~kg}$ \\
\hline $\mathrm{CO} 2$ & 190.463 & $\mathrm{~kg}$ \\
\hline $\mathrm{Fe} 2(\mathrm{C} 2 \mathrm{O} 4) 3$ & 7383.69 & $\mathrm{~kg}$ \\
\hline $\mathrm{K} 2 \mathrm{C} 2 \mathrm{O} 4$ & 48.4992 & $\mathrm{~kg}$ \\
\hline $\mathrm{MnC2O4}$ & 1176.8 & $\mathrm{~kg}$ \\
\hline $\mathrm{Na} 2 \mathrm{C} 2 \mathrm{O} 4$ & 885.727 & $\mathrm{~kg}$ \\
\hline $\mathrm{NiC2O4}$ & 7.27351 & $\mathrm{~kg}$ \\
\hline $\mathrm{PbC} 2 \mathrm{O} 4$ & 14.5243 & $\mathrm{~kg}$ \\
\hline $\mathrm{Pu}(\mathrm{C} 2 \mathrm{O} 4) 2$ & 3.31156 & $\mathrm{~kg}$ \\
\hline $\mathrm{SiO} 2$ & 25.5528 & $\mathrm{~kg}$ \\
\hline $\mathrm{SrC2O}$ & 11.8974 & $\mathrm{~kg}$ \\
\hline $\mathrm{UO2C2O4}$ & 1648.69 & $\mathrm{~kg}$ \\
\hline $\mathrm{AgCl}$ & 0.599138 & $\mathrm{~kg}$ \\
\hline
\end{tabular}

Figure 5-11 Input Screen of 3rd Transfer of SpentAcid to Adjustment Tank

Table 5-11 shows the combined output in the adjustment tank. Both the aqueous and solids will remain in the tank, while the solids will be released to the atmosphere. 
Table 5-11 Combined Output in the Adjustment Tank

\begin{tabular}{|c|c|c|c|}
\hline \multirow{3}{*}{ Constituent } & Aqueous & Vapor & Solid \\
\hline & MSnate2 & $\sum \mathbf{M}_{\text {gas }}$ & $\sum M_{\text {Prec }}$ \\
\hline & \multicolumn{3}{|c|}{ (kg) } \\
\hline $\mathrm{H}_{2} \mathrm{O}$ & $6.45 E+5$ & $0.00 \mathrm{E}+0$ & $0.00 \mathrm{E}+0$ \\
\hline $\mathrm{K}_{2} \mathrm{C}_{2} \mathrm{O}_{4}$ & $4.85 E+1$ & $0.00 \mathrm{E}+0$ & $0.00 \mathrm{E}+0$ \\
\hline $\mathrm{Na}_{2} \mathrm{C}_{2} \mathrm{O}_{4}$ & $2.20 \mathrm{E}+3$ & $0.00 \mathrm{E}+0$ & $5.91 E+4$ \\
\hline $\mathrm{Al}(\mathrm{OH})_{3}$ & $0.00 \mathrm{E}+0$ & $0.00 \mathrm{E}+0$ & $9.25 \mathrm{E}+3$ \\
\hline $\mathrm{Na}_{2} \mathrm{CO}_{3}$ & $1.90 \mathrm{E}+3$ & $0.00 E+0$ & $0.00 \mathrm{E}+0$ \\
\hline $\mathrm{Fe}(\mathrm{OH})_{3}$ & $9.62 \mathrm{E}+1$ & $0.00 E+0$ & $4.11 \mathrm{E}+3$ \\
\hline $\mathrm{HgO}$ & $2.14 \mathrm{E}+1$ & $0.00 \mathrm{E}+0$ & $2.72 \mathrm{E}+2$ \\
\hline $\mathrm{Mn}(\mathrm{OH})_{2}$ & $5.81 \mathrm{E}+0$ & $0.00 E+0$ & $8.66 \mathrm{E}+2$ \\
\hline $\mathrm{Ni}(\mathrm{OH})_{2}$ & $7.17 \mathrm{E}-1$ & $0.00 \mathrm{E}+0$ & $5.85 \mathrm{E}+0$ \\
\hline $\mathrm{NaNO}_{3}$ & $1.98 \mathrm{E}+4$ & $0.00 \mathrm{E}+0$ & $0.00 \mathrm{E}+0$ \\
\hline $\mathrm{NaOH}$ & $2.88 \mathrm{E}+4$ & $0.00 E+0$ & $0.00 \mathrm{E}+0$ \\
\hline $\mathrm{Ag}_{2} \mathrm{CO}_{3}$ & $0.00 \mathrm{E}+0$ & $0.00 \mathrm{E}+0$ & $4.46 \mathrm{E}+0$ \\
\hline $\mathrm{Ag}_{2} \mathrm{O}$ & $2.41 \mathrm{E}-1$ & $0.00 \mathrm{E}+0$ & $0.00 \mathrm{E}+0$ \\
\hline $\mathrm{CaC}_{2} \mathrm{O}_{4} \cdot 1 \mathrm{H}_{2} \mathrm{O}$ & $0.00 \mathrm{E}+0$ & $0.00 \mathrm{E}+0$ & $4.15 E+2$ \\
\hline $\mathrm{CaCl}_{2} \cdot \mathrm{CaO}$ & $2.67 E+0$ & $0.00 E+0$ & $0.00 \mathrm{E}+0$ \\
\hline $\mathrm{Na}_{2} \mathrm{SiO}_{3}$ & $7.19 \mathrm{E}+1$ & $0.00 \mathrm{E}+0$ & $0.00 \mathrm{E}+0$ \\
\hline $\mathrm{NaAlO}_{2}$ & $5.20 E+3$ & $0.00 \mathrm{E}+0$ & $0.00 \mathrm{E}+0$ \\
\hline $\mathrm{NaCl}$ & $1.27 \mathrm{E}+2$ & $0.00 \mathrm{E}+0$ & $0.00 \mathrm{E}+0$ \\
\hline $\mathrm{NaNO}_{2}$ & $7.92 E+3$ & $0.00 \mathrm{E}+0$ & $0.00 \mathrm{E}+0$ \\
\hline $\mathrm{PbO}$ & $1.42 \mathrm{E}+1$ & $0.00 E+0$ & $0.00 \mathrm{E}+0$ \\
\hline $\mathrm{Pu}(\mathrm{OH})_{4}$ & $0.00 \mathrm{E}+0$ & $0.00 \mathrm{E}+0$ & $2.46 \mathrm{E}+0$ \\
\hline $\mathrm{SrCl}_{2}$ & $6.74 \mathrm{E}-1$ & $0.00 \mathrm{E}+0$ & $0.00 \mathrm{E}+0$ \\
\hline $\mathrm{SrCO}_{3}$ & $0.00 \mathrm{E}+0$ & $0.00 \mathrm{E}+0$ & $9.37 \mathrm{E}+0$ \\
\hline $\mathrm{UO}_{2}(\mathrm{OH})_{2}$ & $0.00 \mathrm{E}+0$ & $0.00 \mathrm{E}+0$ & $1.40 \mathrm{E}+3$ \\
\hline $\mathrm{UO}_{2} \mathrm{Cl}_{2}$ & $6.56 \mathrm{E}-1$ & $0.00 \mathrm{E}+0$ & $0.00 \mathrm{E}+0$ \\
\hline
\end{tabular}

By comparing the solids originally in the tank, Msludge $=27,769.5 \mathrm{~kg}-13,296.0 \mathrm{~kg}$ $=14,474 \mathrm{~kg}$ to the final total, $\sum$ M Prec + Msludge4 $=74,913 \mathrm{~kg}+6,584 \mathrm{~kg}=81,497$ $\mathrm{kg}$, we can approximate a mass increase in the original solids by a factor of greater than 5; therefore, although oxalic acid will help remove sludge heels from tanks destined to be closed, it can significantly increase the volume of solids within the system. 


\subsubsection{Energy Balance Modeling}

Energy balances are used to calculate the bounding temperature changes associated with heel removal in the treatment tank and the caustic adjustments in the adjustment tank. Since three strikes will occur, only the bounding cases are analyzed.

In order to calculate the amount of maximum heat gained by adding $8 w t \%$ oxalic acid in a 20:1 volume ratio with 5,000 gallons of sludge, an energy balance was performed using Equation 5-6. The initial temperature will be $25^{\circ} \mathrm{C}$ for the oxalic acid solution and $50^{\circ} \mathrm{C}$ for the sludge.

$$
\text { ESludge1 }+E_{\text {Acid }}+E_{\text {HeatR }} \times \text { E }_{\text {Dissolved }}
$$

Where:

$$
\begin{aligned}
& E_{\text {initialsludge }}=E \text { nergy of the sludge going to equilibrium } \\
& E_{\text {acid }}=\text { E nergy of } 8 w t \% \text { oxalic acid } \\
& E_{H e a t R} x n=E \text { nergy gained by the reaction of sludge to acid } \\
& E_{100 \% \text { Dissolved }}=\text { Energy required to dissolve } 100 \% \text { of the sludge }
\end{aligned}
$$

To calculate the maximum heat gained by adding spent solution and excess acid to a (pre-charged $\mathrm{pH}$ ) adjustment tank of $50 \mathrm{wt} \%$, an energy balance is performed using Equation 5-7. The initial temperature will be $25^{\circ} \mathrm{C}$ for the caustic and $50^{\circ} \mathrm{C}$ for the spent solution and excess acid. Conservatively, caustic is simply assumed to be added to unspent oxalic acid. The formula for the addition of caustic into the oxalic acid is summarized in Equation 5-7.

$$
\mathrm{E}_{\mathrm{Acid}}+\mathrm{E}_{\mathrm{NaOH}}+\mathrm{E}_{\text {Adjustment }}+\mathrm{E}_{\text {Dilution }}=\mathrm{E}_{\mathrm{pH}, 14}
$$


Where:

$E_{\text {oxalicacid }}=$ Energy of 100,000 gallons of $8 w t \%$ oxalic acid

$\mathrm{E}_{\mathrm{NaOH}}=\mathrm{E}$ nergy of $50 \mathrm{wt} \% \mathrm{NaOH}$ required to adjust the $\mathrm{pH}$

$\mathrm{E}_{\mathrm{pH}, 14}=\mathrm{O}$ verall energy required to adjust the $\mathrm{pH}$

EHeatR $x n=$ Energy gained by the reaction of oxalic acid to caustic

$E_{\text {Dilution }}=$ Energy change by the dilution of $\mathrm{NaOH}$

\subsubsection{Temperature Modeling}

The maximum temperature associated with each evolution above is calculated using OLI Stream Analyzer ${ }^{\circ}$ as an enthalpy change, but setting the change to zero, hence calculating temperature. The calculated temperatures are shown in Table 5-12.

Table 5-12 Treatment Tank and Adjustment Tank Temperatures

\begin{tabular}{|c|c|c|}
\hline Step in Treatment Process & $\begin{array}{c}\text { Temp } \\
\left({ }^{\circ} \mathrm{C}\right)\end{array}$ & $\begin{array}{l}\text { - from prev } \\
\text { step }\left({ }^{\circ} \mathrm{C}\right)\end{array}$ \\
\hline Tsludge1 = Initial sludge heel temperature (temp) & 50 & NA \\
\hline $\mathrm{T}_{\text {Acid }}=$ Initial temp of oxalic acid when added to tank & 25 & NA \\
\hline $\mathrm{T}_{1}=$ R esultant temp from first acid strike & 39.9 & +14.9 \\
\hline$T_{2}=$ Resultant temp from second acid strike & 30.8 & -9.09 \\
\hline $\mathrm{T}_{3}=$ Resultant temp from third acid strike & 25 & -5.8 \\
\hline$T_{\text {supernate }}=$ Adjustment supernate heel temp & 25 & NA \\
\hline$T_{\text {caustic }}=$ Temp of caustic & 25 & NA \\
\hline Tpre-charge $=$ Temp of pre-charged tank & 30.6 & +30.6 \\
\hline $\begin{array}{l}\mathrm{T}_{\text {Aq1 }} \text { \&excess }=\text { Temp after aqeous } 1 \& \text { excess added to } \\
\text { adjustment tank }\end{array}$ & 64.6 & +34.1 \\
\hline $\begin{array}{l}\mathrm{T}_{\text {Aq2 }} \& \text { excess } \\
\text { adjustment tank }\end{array}$ & 63.56 & -1.1 \\
\hline $\begin{array}{l}\mathrm{T}_{\text {Aq3 }} \text { \&excess } \\
\text { adjustment tank }\end{array}$ & 63.0 & -0.5 \\
\hline
\end{tabular}

If 100,000 gallons of $8 w t \%$ oxalic acid are is added to the 5,000 gallons of HWCS, the resultant temperature is $32.67^{\circ} \mathrm{C}$, slightly less than $T_{1}$. If none of the acid reacts, 
and 100,000 gallons of $8 w t \%$ oxalic acid are combined with the 5.8 trucks of caustic, the resulting temperature is $73.46^{\circ} \mathrm{C}$. Although this value $\left(73.46^{\circ} \mathrm{C}\right)$ is larger than the maximum shown in Table 5-12, it is considered unrealistic and is discounted. If dissolution were not observed (per tanker addition, approximately 3,000 gallons) acid additions would be stopped.

\subsection{Maximum Vapor Generated}

Based on the quantity of inflows and the kinetics of the reaction, although seven types of vapor can form, only two species of vapor are shown to be generated in sufficient quantities to potentially result in overpressurization. They are $\mathrm{CO}_{2}$ vapor and $\mathrm{H}_{2} \mathrm{O}$ vapor.

\subsubsection{Maximum Carbon Dioxide}

In order to maximize the amount of $\mathrm{CO}_{2}$ and $\mathrm{H}_{2} \mathrm{O}$ released as a gas, 100,000 gallons of oxalic acid was allowed to react with all of the carbonate that was present in the inflow as shown in Figure 5-12.

\begin{tabular}{|c|c|c|c|c|}
\hline Variable & CArbonate stre & Acid* & Sum2 & Unit \\
\hline \multicolumn{5}{|c|}{ Mix Parameters } \\
\hline Ratio & 10 & 1.0 & & -- \\
\hline Proportion & 0.5 & 0.5 & 1.0 & -- \\
\hline \multicolumn{5}{|c|}{ Stream Parameters } \\
\hline Stream Arnt - & 136940 & $3.80217 \mathrm{e} 5$ & $3.93911 \mathrm{e} 5$ & $\mathrm{~kg}$ \\
\hline Temperature & $=250$ & 25.0 & 25.0 & ${ }^{\circ} \mathrm{C}$ \\
\hline Pressure & 10 & 1.0 & 1.0 & atm \\
\hline \multicolumn{5}{|c|}{ Inflows } \\
\hline $\mathrm{H} 2 \mathrm{O}$ & 132470 & $3.498 \mathrm{e} 5$ & $3.63047 e 5$ & $\mathrm{~kg}$ \\
\hline $\mathrm{CaCO} 3$ & 4200 & - & 420.0 & $\mathrm{~kg}$ \\
\hline $\mathrm{PbCO} 3$ & 170 & - & 17.0 & $\mathrm{~kg}$ \\
\hline $\mathrm{SrCO} 3$ & 100 & - & 10.0 & $\mathrm{~kg}$ \\
\hline $\mathrm{C} 2 \mathrm{H} 2 \mathrm{OA}$ & & $30417 n$ & $30417 n$ & $\mathrm{~kg}$ \\
\hline
\end{tabular}

Figure 5-12 Input Screen to Maximum Carbon Dioxide

The maximum temperature was calculated in Section 5.4 .5 to be $64.62^{\circ} \mathrm{C}$. The maximum gas generated was determined using the gas fraction function of $\mathrm{OLI}{ }^{\circ}$. 
The vapor output is determined to be 253 liters. Although this is a conservative assumption, it allows the $\mathrm{CO}_{2}$ and $\mathrm{H}_{2} \mathrm{O}$ production to be maximized.

The reaction of acid and the carbonate in the sludge cannot be modeled because the $\mathrm{CO}_{2}$ is not released as a gas, but instead reacts with the solid/aqueous and is not released.

\subsubsection{Maximum Water Vapor}

The reaction of an acid plus a base results in a salt and water. Reacting an acid with a base, therefore, will result in the maximum amount of $\mathrm{H}_{2} \mathrm{O}$ vapor formed. The change in temperature is first calculated by setting the enthalpy change to zero, and then using that temperature to calculate the liters of gas formed. This calculation adds 100,000 gallons of $8 \mathrm{wt} \%$ oxalic acid to 17,400 liters of $50 \mathrm{wt} \% \mathrm{NaOH}$ and calculates less than 770 liters of gas at $73.5^{\circ} \mathrm{C}$.

\subsubsection{Corrosion Induced Hydrogen}

If slurry pumps are utilized in the treatment tanks, it will ensure that the oxalic acid is evenly distributed throughout the sludge, therefore, enhancing the dissolution process. The slurry pumps will erode away the sludge as the acid decreases the strength of the bonds binding the sludge particles. During this process, radiolysis of the acidic solution and corrosion of the carbon steel components in the treatment tanks, upon contact with the acidic solution, will result in hydrogen generation. As part of this research, the corrosion of the carbon steel components in the treatment tank, upon contact with the oxalic acid, is considered.

Figure 5-13 provides laboratory measured corrosion rates for representative carbon steel coupons in a 4 wt\% and $8 w t \%$ oxalic acid solution [Wiersma, 2004:43]. 


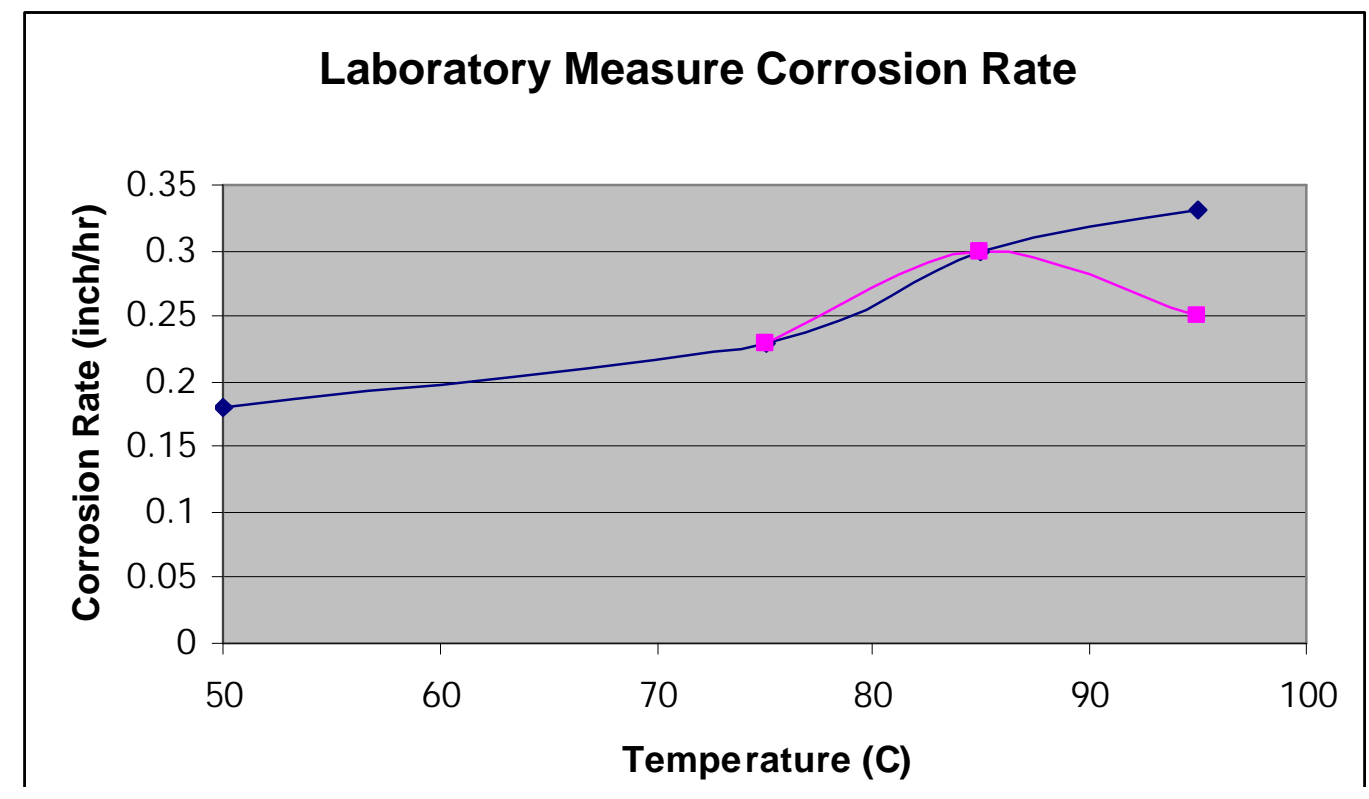

Figure 5-13 Measured Corrosion Rates for Oxalic Acid Exposed Steel

Since the maximum temperature is calculated above as $73.5^{\circ} \mathrm{C}$, we can estimate the bounding corrosion rate as 0.23 inches/hour, the volumetric flowrate of carbon steel consumed can be calculated using Equation 5-8 [Lang, 2004:11].

$$
V_{\text {es }}=\text { Corrosion Rate }(\mathrm{ft} / \text { day }) \times \text { Surface Area }\left(\mathrm{ft}^{2}\right)
$$

Where:

$\mathrm{V}_{\mathrm{CS}}=$ volumetric rate of carbon steel consumed per time $\left(\mathrm{ft}^{3} /\right.$ day)

Corrosion rate of carbon steel in $8 \mathrm{wt} \%$ oxalic acid $=$

$$
(0.23 \mathrm{E}-05 \mathrm{in} / \mathrm{hr}) \times(24 \mathrm{hr} / \text { day }) \times(1 \mathrm{ft} / 12 \mathrm{inch})=0.6 \mathrm{E}-5 \mathrm{ft} / \mathrm{day}
$$

The surface area of the carbon steel is bound by $14,739 \mathrm{ft}^{2}$ [Phillips, 2004]. The amount of carbon steel consumed and hydrogen produced can be determined by Reactions 5-1 and 5-2 which occur from hydrogen generation due to corrosion of carbon steel.

$$
\begin{gathered}
2 \mathrm{Fe}^{\mathrm{O}}+6 \mathrm{H}^{+} \cdot 2 \mathrm{Fe}^{+}+3 \mathrm{H}_{2} \\
\mathrm{Fe}^{0}+2 \mathrm{H}^{+} \cdot \mathrm{Fe}^{+2}+\mathrm{H}_{2}
\end{gathered}
$$


The molar flow rate of carbon steel consumed is calculated using Equation 5-9 and Equation 5-10.

$$
\begin{aligned}
& m_{C S}=\underline{\mathrm{V}}_{\underline{\mathrm{CS}}}-\underline{\mathrm{CS}} \times 28,317 \mathrm{~cm}^{3} / \mathrm{ft}^{3}=5.86 \mathrm{E}+07 \mathrm{~cm}^{3} / \mathrm{ft}^{3} \\
& m_{H 2}=m_{e S}\left(n_{H 2} / n_{e S}\right)
\end{aligned}
$$

Where:

$$
\begin{aligned}
& V_{e s}= \text { Volumetric rate of carbon steel consumed per time }\left(\mathrm{ft}^{3} /\right. \text { day) } \\
& \cdot e s= \text { Density of carbon steel }(\mathrm{g} / \mathrm{ml})=7.83 \mathrm{~g} / \mathrm{ml} \\
& m_{e s}= \text { Molar flow rate of carbon steel consumed (mole } / \text { day) } \\
& \mathrm{MW} \text { es }=\text { molecular weight of carbon steel }(\mathrm{g} / \text { mole) }=55.82 \mathrm{~g} \\
& m_{H 2}=\text { molar flow rate of hydrogen produced (mole } / \text { day) } \\
&\left.n_{H 2}=\text { moles of hydrogen produced (mole) }=1.5 \text { mole (from Reaction } 5-1\right)+1 \\
&\quad \text { mole (from Reaction } 5-2) \\
& n_{e s}= \text { moles of carbon steel consumed (mole) }=1 \text { mole (from Reaction 5-1 } \\
& \text { and Reaction 5-2) }
\end{aligned}
$$

The volumetric flow rate of hydrogen generated due to corrosion of carbon steel can be determined by Equation 5-11.

$$
V_{H 2}=\underline{\left(m_{H 2}\right.} \underset{P T T}{P} \times(\text { day } / 24 \mathrm{hr}) \times\left(35.31 \mathrm{ft}^{3} / \mathrm{m}^{3}\right)
$$


Where:

$$
\begin{aligned}
& m_{H 2}=\text { molar flow rate of hydrogen produced (mole/day) } \\
& V_{H 2}=\text { Hydrogen generation rate due to corrosion }\left(\mathrm{ft}^{3} / \mathrm{hr}\right) \\
& \mathrm{R}=8.314\left(\mathrm{~m}^{3}-\mathrm{Pa} / \text { mole- } \mathrm{K}\right) \\
& \mathrm{T}=346.6 \mathrm{~K} \\
& \mathrm{P}=101,325 \mathrm{~Pa} \\
& \mathrm{~V}_{\mathrm{H} 2}=362 \mathrm{ft}^{3} / \mathrm{hr}
\end{aligned}
$$

The bounding hydrogen generation rate from corrosion can be approximated as less than $362 \mathrm{ft}^{3} / \mathrm{hr}$. For certain tanks, this may overwhelm the tank purge. Further evaluation or ventilation upgrades, therefore, are considered required.

\subsection{Conclusion on Material Balance and Safety Impacts}

Based on the modeling, acid aided heal removal should reduce the heel size by a factor of ten, while increasing the overall solids in the system by a factor of greater than five. The modeling also shows that overpressurization and overheating should not be significant concerns. The maximum gas volume in the treatment tank will be less than 255 liters at the maximum calculated temperature of less than $65^{\circ} \mathrm{C}$.

The maximum calculated gas in the $\mathrm{pH}$ adjustment tank at the maximum calculated temperature will be less than 770 liters at $74.5^{\circ} \mathrm{C}$. Corrosion induced hydrogen from the cooling coil corrosion is determined to be a potential concern at a generation rate of $362 \mathrm{ft}^{3} / \mathrm{hr}$. Further evaluation and/or ventilation upgrades may be required. 


\section{ENERGETIC COMPOUNDS}

\subsection{Introduction to Energetics}

The purpose of this chapter is to determine the impacts on energetic compounds associated with using oxalic acid solution to dissolve sludge heels in SRS HLW tanks.

This chapter is different from Chapter 5, because the process database is not generally designed to characterize and/or quantify energetic compounds. Instead, each family of energetic compounds must be individually evaluated and where necessary, sample data and "spiking" the material balance is performed as available. The spiked material balance contained in Appendix 3 does not represent projected quantities of material (or all of the energetic compounds), but instead introduces significantly inflated quantities to clearly identify behavior and other characteristics of interest.

Hobbs [1999] shows that identified energetic compounds in the SRS HLW tanks can be grouped into 14 families. Other than hydrogen, which is already considered a concern, there are 13 families. They are:

1. metal fulminates

2. metal azides

3. metal $\mathrm{NO}_{x}$ compounds

4. metal amine complexes

5. metal cynides/cyanates

6. metal acetylides

7. nitrate/oxalate mixtures

8. metal oxalates

9. peroxides

10. metal halogenates and halogens

11. metal nitrides

12. ammonia compounds

13. organics 
Although 13 families have been identified in the SRS HLW, not all may be applicable or impacted when using oxalic acid and subsequent activities to aid in SRS HLW Tanks 1-15 sludge heel removal.

\subsection{Initial Chemistry}

The liquid contained within the treatment tank, immediately prior to beginning oxalic acid aided heel removal, will have a low ionic strength, since the vast majority of the soluble constituents will have been washed out during the previous bulk waste removal activities.

During the acid-strikes, the sludge heel will undergo dissolution, with solids, aqueous, and vapors possibly being formed. The spike tank, at the time of each acid addition, is envisioned to be well agitated and in contact with the sludge for a period of about two weeks for each strike. In all cases, the spent, dissolved sludge solution and any unspent acid will be transferred to the adjustment tank.

Since the adjustment tank will continue to be operated, it will be pre-charged with supernate and or sodium hydroxide to ensure the overall pH does not enter the acidic regime (i.e., pH will remain greater than 7) [Badheka, 2003:80]. Vapors are potentially generated, while solid precipitates will form.

\subsubsection{Recent Receipts and Transfers}

High Level Waste (HLW) originates from separations, decontamination facilities, analytical laboratories, Research and Development laboratories, and Defense Waste Processing Facility (DWPF). Historically, separations produced most of the sludge (volume). Tanks 1-15 have not received solids since the early 1980's, and therefore have been aged (HLW, 2005). The term "transfers" in Table 6-1 refers to supernate transfers from tank to tank, whereas "receipts" in Table 6-2 refers to receiving waste solids from separations. As such, solubles are tracked in Table 6-1, and solids are tracked under Table 6-2. 
Table 6-1A Post 1979 Supernate Transfers (Sheet 1 of 2)

\begin{tabular}{|c|c|c|c|l|}
\hline Yr. & Tank & Source & $\begin{array}{c}\text { Size } \\
(\mathbf{1 E + 4} \text { gal) }\end{array}$ & \multicolumn{1}{|c|}{ Description } \\
\hline 1998 & 2 & NA & 2 & Bearing seal water added \\
\hline 1985 & 2 & NA & 2 & Flush water \\
\hline 1985 & 2 & NA & 3 & Salt mining water \\
\hline 1989 & 2 & NA & 7 & Reel tape calibration/replacement \\
\hline 1985 & 3 & NA & 2 & Reel tape calibration/replacement \\
\hline 1985 & 4 & NA & $4,0.1$ & Reel tape calibration/replacement \\
\hline 1995 & 4 & NA & 0.4 & Thermal expansion \\
\hline 2000 & 5 & 22 & 30 & Supernate \\
\hline 1992 & 6 & NA & 20 & Reel tape calibration/replacement \\
\hline 2000 & 6 & 22 & 30 & Supernate \\
\hline 1980 & 7 & $242-1 F$ & 1 & Over spec \\
\hline 1980 & 7 & NA & 3 & Miscellaneous addition/transfer \\
\hline 1980 & 7 & 10 & 10 & Concentrated supernate \\
\hline 1980 & 7 & 18 & 100 & Dissolved salt \\
\hline 1980 & 7 & 33 & 10 & Concentrated supernate \\
\hline 1980 & 7 & 8 & 100 & Supernate \\
\hline 1980 & 7 & 4 & 3 & Supernate \\
\hline 1981 & 7 & $242-1 F$ & 2 & Evaporator Overheads \\
\hline 1981 & 7 & & 0.8 & Fdb-1 catch tank transfer \\
\hline 1981 & 7 & 8 & 20 & Supernate \\
\hline 1981 & 7 & 18 & 200 & Salt transfer \\
\hline 1981 & 7 & 26 & 200 & Concentrated supernate \\
\hline 1982 & 7 & $242-1 F$ & 0.8 & Evaporator Overheads \\
\hline 1982 & 7 & 18 & 60 & Salt transfer \\
\hline 1982 & 7 & 26 & 40 & Supernate \\
\hline 1983 & 7 & NA & 30 & Concentrated supernate \\
\hline 1983 & 7 & 26 & 200 & Concentrated supernate \\
\hline 1983 & 7 & $242-1 F$ & 3 & Evaporator Overheads \\
\hline 1984 & 7 & 26 & 20 & Flush \\
\hline 1984 & 7 & NA & 6,2 & Flush + catch tank \\
\hline 1986 & 7 & NA & $2 @ 6$ & Unexplained increase/decrease \\
\hline 1990 & 7 & NA & $2 @ 3$ & Thermal expansion \\
\hline 1992 & 7 & NA & $4 @ .1$ & Reel tape error + thermal/transfer \\
\hline 1994 & 7 & NA & $2 @ .1$ & Inter-area flush transfer \\
\hline 1980 & 9 & NA & 0.3 & Flush water \\
\hline 1981 & 9 & NA & 1 & Cooling coil water leak-chromate water \\
\hline 1982 & 9 & NA & $1,0.1$ & Reel tape calibration/replacement \\
\hline 1980 & 10 & 23 & 30 & Miscellaneous addition/transfer \\
\hline 1983 & 10 & NA & 10 & Reel tape calibration/replacement \\
\hline 1985 & 10 & NA & 7 & Salt mining, reel tape, NaOH \\
\hline 1986 & 10 & NA & 7 & Reel tape calibration/replacement \\
\hline 1989 & 10 & NA & 2 & Reel tape calibration/replacement \\
\hline
\end{tabular}


Table 6-1B Post 1979 Supernate Transfers

(Sheet 2 of 2)

\begin{tabular}{|c|l|l|l|l|}
\hline Yr. & Tank & Source & $\begin{array}{c}\text { Size } \\
(\mathbf{1 E + 4} \text { gal) }\end{array}$ & \\
\hline 1983 & 11 & NA & 0.1 & Tank inleakage from rain storm \\
\hline 1984 & 11 & NA & 0.3 & Tank inleakage from rain storm \\
\hline 1984 & 11 & NA & 3 & Tank inleakage from rain storm \\
\hline 1984 & 11 & NA & 0.7 & Reel tape calibration/replacement or \\
\hline 1986 & 11 & NA & 0.3 & Tank inleakage from rain storm \\
\hline 1992 & 11 & NA & 0.2 & Rain water \\
\hline 1995 & 11 & NA & 1 & Evaporation \\
\hline 1984 & 12 & NA & 0.4 & Tank inleakage from rain storm \\
\hline 1989 & 12 & NA & 0.4 & Reel tape calibration/replacement or \\
\hline 1992 & 12 & NA & 0.1 & Reel tape calibration/replacement or \\
\hline 1980 & 13 & NA & 0.7 & Flush water \\
\hline 1981 & 13 & 11,22 & 7 & Supernate \\
\hline 1981 & 13 & 32 & 70 & Supernate \\
\hline 1980 & 13 & 21 & 40 & Supernate \\
\hline 1980 & 13 & $242-1 H$ & 10 & Overheads \\
\hline 1982 & 13 & 31,29 & $2 @ 30$ & Concentrated supernate \\
\hline 1982 & 13 & 10 & 30 & Salt transfer \\
\hline 1982 & 13 & 35 & 100 & Supernate \\
\hline 1982 & 13 & 30 & 30,80 & Concentrated supernate \\
\hline 1981 & 13 & 37,36 & 500,700 & Concentrated supernate \\
\hline 1983 & 13 & NA & 6 & Flush water \\
\hline 1983 & 13 & NA & 3 & Water and oxalic acid \\
\hline 1985 & 13 & 24 & 1 & Tank 42 hot water rinse \\
\hline 1983 & 13 & $242-1 H$ & 4 & Overheads \\
\hline 1986 & 13 & 33 & 10 & Supernate \\
\hline 1986 & 13 & 22 & 30 & Supernate \\
\hline 1985 & 13 & NA & 3 & Flushes \\
\hline 1986 & 13 & 32 & 80 & Supernate \\
\hline 1987 & 13 & NA & 1 & Decontamination water \\
\hline 1987 & 13 & 35 & 50 & Supernate \\
\hline 1985 & 13 & 37 & 600 & Concentrated supernate \\
\hline 1985 & 13 & 30 & 200 & Supernate \\
\hline 1985 & 13 & 36 & 400 & Concentrated supernate \\
\hline 1980 & 15 & 16 & 200 & Wash water \\
\hline 1982 & 15 & NA & 30 & Bearing seal water added \\
\hline & & & &
\end{tabular}


As shown in the last column of Table 6-1, Tanks 1-15 are recorded as not receiving DWPF recycle. Entries shown are for sources of supernate received into Tanks 1-15 since 1980. The Tanks 1, 8, and 14 are not shown in Table 6-1 because they have not received supernate transfers since 1980 . The limited solids received in Tanks 115 since 1980 are shown in Table 6-2. (Note: Tanks 4, 8, 11, and 15 were the only tanks out of Tanks 1-15 which received any solids since the beginning of 1980).

Table 6-2 Post 1979 Waste Receipts into Tanks 1-15

\begin{tabular}{|c|c|c|l|}
\hline Year & Tank & $\begin{array}{c}\text { Size } \\
(\mathbf{1 E + 0 4} \text { gal) }\end{array}$ & \multicolumn{1}{c|}{ Campaign } \\
\hline 1980 & 4 & $2.5 \mathrm{E}+5$ & Purex-plutonium uranium separation \\
\hline 1980 & 8 & $1.1 \mathrm{E}+6$ & Purex-plutonium uranium separation \\
\hline 1981 & 11 & $2.6 \mathrm{E}+5$ & HM - H Area modified Purex \\
\hline 1980 & 15 & $6.0 \mathrm{E}+3$ & HM - H Area modified Purex \\
\hline
\end{tabular}

Table 6-2 shows the last Tank 1-15 sludge receipt was prior to 1982 [HLW, 2005]. Since DWPF was not yet operational, Tanks 1-15 did not receive DWPF recycle, and therefore DWPF organics are not a concern. The aging of Tanks 1-15 ensures that volatile organics no-longer represent a flammability concern [Britt, 2003:42]. Table 6-3 summarizes the applicable organics and chemicals identified in Hobbs [1999] that are potentially present in Tanks 1-15. 
Table 6-3 Miscellaneous Organics and Chemicals

\begin{tabular}{|c|c|c|}
\hline Parent & Constituent & Formula \\
\hline \multirow[t]{3}{*}{ ammonia } & ammonia/ammonium ion & $\mathrm{NH}_{3} / \mathrm{NH}_{4}$ \\
\hline & hydrazine & $\mathrm{N}_{2} \mathrm{H}_{4}$ \\
\hline & hydroxylamine & $\mathrm{NH}_{2} \mathrm{OH}$ \\
\hline dodecane & dodecane & $\mathrm{C}_{12} \mathrm{H}_{26}$ \\
\hline \multirow[t]{4}{*}{ TBP } & tri-n-butyl phos phate (tributyl & $\left(\mathrm{CH}_{3}\left[\mathrm{CH}_{2}\right]_{3} \mathrm{O}\right)_{3} \mathrm{PO}$ \\
\hline & di-n-butyl phosphate & $\mathrm{C}_{8} \mathrm{H}_{18} \mathrm{O}_{4} \mathrm{P}_{1}$ (1 neg. charge) \\
\hline & mono-n-butyl phosphate & $\mathrm{C}_{4} \mathrm{H}_{9} \mathrm{O}_{4} \mathrm{P}_{1}(2$ neg. charge) \\
\hline & n-butanol & $\mathrm{C}_{4} \mathrm{H}_{10} \mathrm{O}$ \\
\hline \multirow[t]{2}{*}{ acid } & gluconic acid & $\mathrm{C}_{6} \mathrm{H}_{12} \mathrm{O}_{7}$ \\
\hline & ascorbic acid & $\mathrm{C}_{6} \mathrm{H}_{8} \mathrm{O}_{7}$ \\
\hline resins & ion-exchange resins & $\left(\mathrm{C}_{8} \mathrm{H}_{8}\right) \mathrm{n}$ \\
\hline CST & polydimethylsiloxane & $\left(\mathrm{C}_{2} \mathrm{H}_{6} \mathrm{OSi}\right) \mathrm{n}$ \\
\hline \multirow[t]{5}{*}{ defoamers } & hydrogenated tallow & NA \\
\hline & thylene glycol (1,2- & $\mathrm{C}_{2} \mathrm{H}_{6} \mathrm{O}_{2}$ \\
\hline & methylcellulose & $\mathrm{CH}_{4} \mathrm{O} \times$ Unspecified \\
\hline & 2,4,7,9-tetramethyl-5 - & $\mathrm{C}_{14} \mathrm{H}_{26} \mathrm{O}_{2}$ \\
\hline & & siloxanes \\
\hline
\end{tabular}

\subsection{Acidic Chemistry Qualitative Assessment}

Eventually during waste removal, solids will become harder and harder to remove, and oxalic acid will be required to dissolve the solids. The oxalic acid additions to the tank will, at a minimum, change the chemistry. Temperatures may slightly increase from exothermic reactions. Because of corrosion, the maximum temperature for both the treatment tank and the $\mathrm{pH}$ adjustment tank is recommended to be maintained at less than $50^{\circ} \mathrm{C}$.

\subsubsection{Metal Fulminates}

The first family of energetic compounds considered are metal fulminates. Metal fulminates are compounds similar to $\mathrm{XC}_{2} \mathrm{~N}_{2} \mathrm{O}_{2}$, where " $\mathrm{x}$ " represents a metal and 
$\mathrm{C}_{2} \mathrm{~N}_{2} \mathrm{O}_{2}$ is fulminate. Generally metal fulminates form in two steps. In the first step, the metal is nitrated with an excess of nitric acid. Refer to Equation 6-1.

$$
\mathrm{X}+3 \mathrm{OHNO} 2 \cdot \mathrm{xNO}_{3}+\mathrm{OHNO}_{3}+\mathrm{NO}_{2}
$$

As shown in the material balance contained in Appendix 3, the overall moles of $\mathrm{NO}_{3}{ }^{-}$ and $\mathrm{NO}_{2}^{-}$will decrease as part of the bulk waste and acid treatment activities. Table 6-4 summarizes the expected change to the overall quantities of $\mathrm{NO}_{3}{ }^{-}$and $\mathrm{NO}_{2}{ }^{-}$.

\section{Table 6-4 Abundance of $\mathrm{NO}_{3} / \mathrm{NO}_{2}$ During Acid Cleaning}

\begin{tabular}{|c|c|c|c|c|}
\hline \multirow{2}{*}{ Stage } & Total & Aqueous & Vapor & Solid \\
\cline { 2 - 5 } & (\% mol) & \multicolumn{2}{|c|}{ (\% of initial mol) } \\
\hline Pre-bulk waste & $\sim 5000$ & $\sim 5000$ & NA & NA \\
\hline Initial & 100 & 100 & 0 & 0 \\
\hline 70\% Dissolution & 100 & 100 & $<1.5 \mathrm{E}-8$ & 0 \\
\hline $50 \%$ Dissolution & 0 & 0 & 0 & 0 \\
\hline $30 \%$ Dissolution & 0 & 0 & 0 & 0 \\
\hline Supernate add & $\sim 5000$ & $\sim 5000$ & 0 & 0 \\
\hline Caustic add & $\sim 5000$ & $\sim 5000$ & 0 & 0 \\
\hline \multicolumn{4}{|r|}{} \\
\hline
\end{tabular}

The increase in $\mathrm{NO}_{2}^{-}$and $\mathrm{NO}_{3}^{-}$during the final two stages reflects the fact that normal tank farm supernate, to be added as part of restoring the $\mathrm{pH}$, has elevated soluble $\mathrm{NO}_{2}{ }^{-}$and $\mathrm{NO}_{3}{ }^{-}$compared to the initial sludge heel dissolution starting point.

Besides nitrates, alcohol \{i.e., organics having- $\mathrm{OH}\}$ is also needed to form heavy metal fulminate. The nitrated metal and excess acid would be added to the alcohol, such as ethanol, forming metal fulminate. Refer to Equation 6-2.

$$
\mathrm{XNO}_{3}+\mathrm{HNO}_{3}+\mathrm{C}_{2} \mathrm{H}_{6} \mathrm{O} \cdot \mathrm{X}(\mathrm{ONC})_{2}
$$

Alcohols are not used in bulk quantities within the tank farm and are only present in trace amounts as a result of laboratory operations and decomposition of tri-n-butyl phosphate $\left\{1 . e .,\left(\mathrm{CH}_{3}\left[\mathrm{CH}_{2}\right]_{3} \mathrm{O}\right)_{3} \mathrm{PO}\right\}$ and other organics. Methanol \{i.e., $\left.\mathrm{CH}_{4} \mathrm{O}\right\}$ and 
isopropanol \{i.e., $\left.\mathrm{C}_{3} \mathrm{H}_{8} \mathrm{O}\right\}$ are two of the more likely impurities that could help form alcohols. For example, monosodium titinate (MST) slurries, prepared and submitted by vendors, have been analyzed to contain $<0.1$ by volume alcohols [Hobbs, 1999:23].

Silver fulminate \{i.e., $\mathrm{Ag}_{2} \mathrm{C}_{2} \mathrm{~N}_{2} \mathrm{O}_{2} \cdot \mathrm{Hf}=+180 \mathrm{Kjoule} /$ mole $\}$ and mercury fulminate \{.e., $\left.\mathrm{HgC}_{2} \mathrm{~N}_{2} \mathrm{O}_{2} \cdot \mathrm{Hf}=+200 \mathrm{Kjoule} / \mathrm{mole}\right\}$ are two energetics which potentially raise the most concern as they are used in explosives and blasting caps. Reports show that mercury fulminate decomposes when in a gamma field [Ketusky, 2005:31]. Recent studies further detail these phenomena as the mercury fulminate transforming into a less energetic form when in a gamma field. In a $1 \mathrm{M}$ sodium hydroxide solution and a $1 \mathrm{rad} / \mathrm{hr}$ gamma field, the mercury fulminate would completely decompose. Any silver fulminate and mercury fulminate should have also already decomposed.

Modeling in Appendix 3 shows that mercury fulminate, silver fulminate, and fulminating silver are not expected to form since after bulk waste removal, the sludge is nitrogen depleted, and no significant means is available as part of oxalic acid additions. It is expected that there should be no increase in the possibility of explosive events from fulminates due to the activities and subsequent activities associated with the oxalic acid aided heel removal.

\subsubsection{Metal Azides}

Metal azides are compounds in the form of $\mathrm{XNY}$, where " $\mathrm{X}$ " represents the metal and " $y$ " represents the nitrogen. The formations of metal azides were considered as a result of a reported explosive event that occurred in the 1970's. The incident was associated with dried waste deposits in a feed jet enclosure. It occurred shortly after receiving waste from the flushing of silver-coated saddles in separations.

Hydrazoic acid \{i.e., $\mathrm{HN}_{3} \cdot \mathrm{Hf}=+328 \mathrm{Kjoule} / \mathrm{mole}$ \} is reported to be dangerously explosive with a minimum explosive concentration of about $17 \mathrm{wt} \%$ in aqueous 
solutions. If within the HLW, this acid would easily react with the excess sodium to result in sodium azide $\left\{1 . e ., \mathrm{NaN}_{3} \cdot \mathrm{Hf}=+93 \mathrm{Kjoule} /\right.$ mole\}. Electropositive metal azides are not as energetic and decompose at temperatures only above $300^{\circ} \mathrm{C}$. These metal azides, however, can easily react to form heavy metal azides. Heavy metal azides such as silver \{i.e., $\left.\mathrm{AgN}_{3} \cdot \mathrm{Hf}=+376 \mathrm{Kjoule} / \mathrm{mole}\right\}$ and mercury \{i.e., $\left.\left.\mathrm{Hg}_{3}\left(\mathrm{~N}_{2}\right)_{3}\right\} \cdot \mathrm{Hf}=+590 \mathrm{Kjoule} / \mathrm{mole}\right\}$ are reported to be explosive and have been used in detonation assemblies [Walker, 1999:12].

As shown in Table 6-4, the initial sludge would be nitrogen depleted. Additionally $\mathrm{HN}_{3}$ is extremely soluble and would be quickly removed prior to the start of oxalic acid cleaning. Because of solubility, even if present, hydrazoic acid would remain in solution, while the heavy metals would remain mostly at the bottom of the tank. It is then concluded that there is no likely mechanism in which heavy metal azides could be formed in the waste tanks.

\subsubsection{NOx Compounds}

Although $\mathrm{NO}_{x}$ compounds are compounds that may include nitrites and nitrates, there are also many other different $\mathrm{N}_{\mathrm{X}} \mathrm{O}_{\mathrm{x}}$ anions. Some reported explosive $\mathrm{NO}_{\mathrm{X}}$ compounds include methylcellulose, salts of millon's base (i.e., $(\mathrm{HOHg})_{2} \mathrm{NH}_{2} \mathrm{OH}$, lead hyponitrite \{i.e., $\left.\mathrm{PbN}_{2} \mathrm{O}_{2}\right\}$, silver hyponitrite \{i.e., $\mathrm{Ag}(\mathrm{NO})_{3} \cdot \mathrm{Hf}=-124$ Kjoule/mole\}, and nitrate salts $\left\{\right.$ e.g., $\left.\mathrm{NaNO}_{3}\right\}$.

The only identified source of cellulosic materials into the tank farm is from antifoam B emulsion (I-5\% methylcellulose \{i.e., $\mathrm{CH}_{4} \mathrm{O} \times$ unspecified $\}$. It is used to minimize foaming in HLW evaporators. The quantity of methylcellulose added to the tank farm is very small. No incidents of uncontrolled reactions have been reported during evaporator operations and laboratory evaluations using this defoamer [Hobbs, 1999:15]. The nitration of cellulose occurs only under strongly acidic conditions and elevated temperatures, greater than $160^{\circ} \mathrm{C}$. In the HLW tanks, cellulose will 
decompose during storage due to radiolysis and alkaline hydrolysis [Hobbs, 1999:21). As part of oxalic acid cleaning, the temperatures during acid heel dissolution will be maintained at approximately $50^{\circ} \mathrm{C}$ to minimize corrosion.

In the HLW tanks, nitrate is reduced to nitrite by radiolysis; thus, lower oxidation state nitrogen-oxygen compounds such as hyponitrite $\{\mathrm{NO}\}$ may be produced radiolytically. Mercury, lead, and silver are present in SRS waste, and accordingly, hyponitrite salts with these metals are conceivable.

Since the solubility of $\mathrm{NO}_{3}{ }^{-}$and $\mathrm{NO}_{2}{ }^{-}$approach $90 \mathrm{gram} / 100 \mathrm{gram}$ of water at $25^{\circ} \mathrm{C}$, most should be removed as part of bulk waste removal [Britt, 2003:26). Since lead, silver, and mercury are generally insoluble, the heavy metals would be among the last materials to go into solution. Section 6.3.1 shows that the $\mathrm{NO}_{2}{ }^{-}$and $\mathrm{NO}_{3}{ }^{-}$would be depleted when the acid spikes begin; therefore, the increase in additional energetic $\mathrm{NO}_{x}$ compounds forming above routine HLW conditions is extremely low [Hobbs, 1992:14].

\subsubsection{Metal Amine Complexes}

Amine complexes $\left\{\sim a\right.$ compound derived from $\mathrm{NH}_{4}$ by replacing $\mathrm{H}$ with hydrocarbon radicals $\}$ of metals containing oxyanion ligands $\{\sim$ a polyatomic atom that has a "-" charge $\&$ contains 0 \} have been reported to be explosive and exhibit moderate to strong shock sensitivity. These compounds are particularly hazardous because of the presence of both the fuel (amine) and the oxidant (i.e., oxyanion ligand) in the same compound. SRS waste generally contains two species for forming complexes of this type: metal ions, and oxyanions \{e.g. nitrate, nitrite, and sulphate $\}$ and potentially, ammonia. However, based on the age of the waste, the ammonia would no longer be present [Ketusky, 2003:42).

Metal ions that are present in SRS waste and conceivably form amine complexes, including copper, chromium, cobalt, mercury, palladium, silver, and zinc complexes. Preparation of metal-amine complexes is generally carried out in concentrated 
ammonium hydroxide $\left\{\right.$ i.e., $\mathrm{NH}_{4} \mathrm{OH}$ \} solution or liquid ammonia. Because of the age of the waste in Tanks 1-15, as well as the fact that it is being evaluated after post bulk waste removal, ammonia and ammonium hydroxide concentrations are very low. Table 6-4 above, also shows the decrease in $\mathrm{NO}_{2}^{-}$and $\mathrm{NO}_{3}{ }^{-}$during the oxalic acid aided heel removal. Appendix 3 also shows the decrease in other spiked oxyanion ligands during the oxalic acid aided heel removal effort. It is then concluded that the production of amine complexes would not increase.

\subsubsection{Cyanate and Cyanides}

Metal cyanides $\{$ i.e., $x C N$ \} and metal cyanates $\{$ i.e., $x O C N\}$ are often endothermic, but at elevated temperatures can undergo violent exothermic oxidations and release significant amounts of energy. Solid potassium cyanide fi.e., $\mathrm{K}(\mathrm{CN})_{2} \cdot \mathrm{Hf}=-8.4$ Kjoule/mole\}, and mercury cyanide $\left\{1 . e ., \mathrm{Hg}(\mathrm{CN})_{2} \cdot \mathrm{Hf}=+264 \mathrm{Kjoule} / \mathrm{mole}\right\}$ explode when heated [S wingle, 2004:4]. Mercury cyanate \{i.e., $\left.\mathrm{Hg}(\mathrm{OCN})_{2}\right\}$ explodes when crushed. Endothermic compounds such as cadmium cyanide \{i.e., $\mathrm{Cd}(\mathrm{CN})_{2}$ - $\mathrm{Hf}=+267$ Kjoule/mole $\}$ and nickel cyanide $\left\{1 . e ., \quad \mathrm{Ni}(\mathrm{CN})_{2}\right\}$ can decompose explosively [S wingle, 2004:4).

Potassium, nickel, and mercury are known components of SRS HLW; however, there is no significant source of cyanide and cyanate within the tank farm [B ritt, 2003, 121]. Appendix 3 contains a spike of $\mathrm{Ni}(\mathrm{CN})_{2}$ and $\mathrm{Hg}(\mathrm{OCN})_{2}$ to show how cyanides and cyanate will behave during the oxalic acid aided heel removal effort. It should be noted that cyanide has not been detected in SRS HLW, although in 1986, analysis of a Tank $50 \mathrm{H}$ sample indicated a cyanide concentration of $3.6 \mathrm{ppm}$. Review of the sample analysis indicates that the positive result for cyanide was an artifact of the experimental procedure (Ketusky, 2003:21). Since oxalic acid cleaning will not introduce cyanides or cyanates, there will be no additional risk from cyanides or cyanates during the oxalic acid cleaning. 


\subsubsection{Metal Acetylides}

Hobbs (1999:15) indicates that acetylenic glycol or similar material would be required to produce acetylide. Based solely on the presence of copper, silver, and mercury in HLW, copper acetylide can be considered potentially present in SRS HLW. CUCHO has a solubility of $12.5 \mathrm{~g} / 100 \mathrm{~g}$ of water at $25^{\circ} \mathrm{C}$, requiring an impact as low as $2 \mathrm{E}-09$ Kjoule to explode. Silver acetylide $\{\mathrm{AgCHO}\}$ is a more powerful detonator than $\mathrm{Cu}$ and explodes when heated to $120-140^{\circ} \mathrm{C}$. Mercury acetylide $\left\{\mathrm{Hg}(\mathrm{CHO})_{2}\right\}$ is both shock and heat sensitive. Temperatures during the use of oxalic acid and subsequent $\mathrm{pH}$ adjustment will not reach above approx. $75^{\circ} \mathrm{C}$ as shown in $\mathrm{Chapter} 5$.

Acetylene and terminal alkynes react with metal ions in solid/vapor reaction or in non-aqueous solvents to produce metal acetylides. If a terminal hydrogen atom is not present, no reaction occurs. Radiolytic and chemical decomposition of the acetylenic glycol could produce acetylene, other terminal alkynes, methyl isobutyl ketone and low molecular weight alcohols.

Metal acetylides react with water to produce the alkyne and the corresponding metal hydroxide. The high water content in the waste prevents the accumulation of metal acetylides in the bulk of the waste. Additionally acetylene and terminal alkenes are spiked into the sludge and run to equilibrium using $\mathrm{OLI}^{\circ}$ in Appendix 3. Appendix 3 shows that the formation of metal acetylides is not preferred. Strict controls are placed on the precursors; thus, there is no identified mechanism for the formation and accumulation of metal acetylides. This class of explosive compounds is therefore not a hazard in the tank farm. Oxalic acid heel dissolution will not introduce any of the precursor materials. 


\subsubsection{Nitrate/Oxalate Mixtures}

The reaction of sodium nitrate with sodium oxalate is considered a potentially uncontrollable reaction. The basis is that current documentation shows this mixture as extremely exothermic with the potential to generate large amounts of gas/heat if left uncontrolled.

From Hobbs (1999:4), differential thermal analyses of mixtures of sodium nitrate, sodium nitrite and sodium oxalate indicate that both endothermic and exothermic reactions start at about $150^{\circ} \mathrm{C}$. Endothermic reactions initiate from about $160^{\circ} \mathrm{C}$ to $315^{\circ} \mathrm{C}$, while a single exothermic reaction is initiated in the range from $375^{\circ} \mathrm{C}$ to $450^{\circ} \mathrm{C}$. Calculations in $\mathrm{C}$ hapter 5 show that temperatures will not get this high during oxalic acid treatment or during subsequent $\mathrm{pH}$ adjustment.

Table 6-4 summarizes the expected change to the overall quantities of $\mathrm{NO}_{3}{ }^{-}$and $\mathrm{NO}_{2}{ }^{-}$during oxalic acid heel removal based on $\mathrm{OLI}^{\circledR}$ modeling. Sodium nitrate has a solubility of about $90 \mathrm{~g} / 100 \mathrm{~g}$ water at $25^{\circ} \mathrm{C}$, while sodium oxalate has a solubility of about $3.5 \mathrm{~g} / 100 \mathrm{~g}$ of water $25^{\circ} \mathrm{C}$, meaning that the nitrates and nitrites would be depleted as the oxalates build-up in the bottom of the tank. The oxalic acid addition, therefore, will not increase the probability of a nitrate/oxalate explosive event.

\subsubsection{Oxalates}

As oxalic acid is added to the spike tank, oxalates will increase, not only in the spike tank, but also throughout all of HLW. Historically, during sludge removal from Tank 16, a special procedure using oxalic acid, assisted in removing the final amount of sludge. Under acidic conditions, mercury oxides and silver oxides can react with oxalic acid to produce insoluble mercury oxalate and silver oxalate. When relatively dry, silver oxalate and mercury oxalates are reported to be weakly explosive, at a minimum temperature of $130^{\circ} \mathrm{C}$ [Ketusky, 2003:54]. Experimental testing indicated that neither compound ignites by an electric arc when dispersed in air. Explosions occur only when the materials are confined or dry and in pure form. Since the temperatures will be maintained at approximately $50^{\circ} \mathrm{C}$, and the heel will remain wet, 
mercury and silver oxalates will not present an explosion hazard during oxalic acid cleaning.

\subsubsection{Peroxides}

Peroxides $\left\{\right.$ i.e., similar to $\mathrm{X}_{2} \mathrm{O}_{2}$ \} are highly reactive molecules due to the presence of an oxygen-oxygen linkage. Under activating conditions, the oxygen-oxygen bond may form highly reactive free radicals. These highly reactive radicals can be used to initiate polymerization or curing; consequently, organic peroxides are used as initiators for free-radical polymerization, curing agents for resins, and cross-linking agents for elastomers and polyethylene. There are three possible types of peroxide explosion hazards in HLW. They are as follows:

1) peroxide/organic mixtures

2) organic peroxides

3) metal peroxides

Radiolytic generation of peroxide is well known in aqueous solutions. The radiolytic generation rate for peroxide varies slightly with $\mathrm{pH}$, decreasing slightly in alkaline solutions as compared to acidic solutions. Hydroxyl radical scavengers such as chloride, bromide, iodide, and nitrite, decrease the rate of peroxide formation [Hobbs, 1999:6]. As a gas, oxygen and hydrogen will quickly recombine with hydrogen peroxide to form water.

Because of the high water content of SRS waste, the heavy metal peroxides \{e.g., $\mathrm{Ag}_{2} \mathrm{O} \cdot \mathrm{Hf}=-11 \mathrm{Kjoule} / \mathrm{mole}, \mathrm{CdO} \cdot \mathrm{Hf}=-289 \mathrm{Kjoule} / \mathrm{mole}$, and $\mathrm{Hg}_{2} \mathrm{O} \cdot \mathrm{Hf}=-91$ Kjoule/mole are not stable, and significant quantities are not produced. Potassium peroxide $\left\{\mathrm{K}_{2} \mathrm{O}_{2} \cdot \mathrm{Hf}=-425 \mathrm{Kjoule} / \mathrm{mole}\right\}$ requires cold temperatures $\left(<10^{\circ} \mathrm{C}\right)$ to remain stable in aqueous solutions. Since SRS waste storage conditions are at higher temperatures ( $\geq 25^{\circ} \mathrm{C}$ ), it is clear, based on $\mathrm{C}$ hapter 5 , that potassium peroxide would immediately decompose. 
Sodium peroxide $\left\{1 . e ., \mathrm{Na}_{2} \mathrm{O}_{2} \cdot \mathrm{Hf}=-450 \mathrm{Kjoule} / \mathrm{mole}\right\}$ is stable in solution, but can crystallize from aqueous solutions. It is considered a dangerous fire and explosion risk when in contact with water, alcohols, acids, powdered metals, and organic materials. However, transition metal ions $\{$ e.g., $\mathrm{Fe}, \mathrm{Mn}, \mathrm{Cu}, \mathrm{Co}$, and $\mathrm{Ni}\}$ are known to catalyze the decomposition of sodium peroxide. Since these metals are required to be present in SRS waste and sludge for nuclear criticality control (also shown in Appendix 3, Table 3-1), it is unlikely that appreciable quantities of sodium peroxide will form and crystallize in the tank farms as the result of acid heel dissolution.

Because of the low organic content of the waste, organic peroxides do not present a safety hazard in tank farm operations. Organic peroxides are conceivably produced in waste by the reaction of organics with oxygen-containing radicals $\left\{\right.$ e.g., $\left.\mathrm{OH}^{-}\right\}$or the combination of two alkoxide radicals $\left\{\right.$ e.g., $\left.\mathrm{RO}^{-}\right\}$. These types of radicals are well known products produced by the radiolysis of water and alcohol solutions. The concentration of organics in the waste, however, is very low. As a result, the concentration of organic peroxides generated by either of these pathways is also very low.

Heavy metal peroxides \{e.g., $\mathrm{Ag}_{2} \mathrm{O} \cdot \mathrm{Hf}=-11$ Kjoule/mole; $\mathrm{CdO} \cdot \mathrm{Hf}=-258$ Kjoule/mole; $\mathrm{Hg}_{2} \mathrm{O} \cdot \mathrm{Hf}=-91 \mathrm{Kjoule} / \mathrm{mole}$; and $\left.\mathrm{Zn}_{2} \mathrm{O} \cdot \mathrm{Hf}=-351 \mathrm{Kjoule} / \mathrm{mole}\right\}$ are not stable in water. Because of the high water content of SRS waste, the heavy metal peroxides are not stable, and significant quantities are not produced. Potassium peroxide $\left\{\mathrm{K}_{2} \mathrm{O}_{2}\right\}$ requires cold temperatures $\left(<10^{\circ} \mathrm{C}\right)$ to remain stable in aqueous solutions. Since SRS waste storage conditions are at higher temperatures $\left(\geq 25^{\circ} \mathrm{C}\right)$, as calculated in Chapter 5 , potassium peroxide would quickly decompose. 
Table 6-5 Properties of Peroxides (based on $25^{\circ} \mathrm{C}$ in water or as indicated)

\begin{tabular}{|c|c|c|c|c|c|}
\hline Constituent & $\begin{array}{c}\text { Molecular } \\
\text { Weight }\end{array}$ & $\begin{array}{c}\text { Density } \\
\left(\mathbf{g} / \mathbf{c m}^{\mathbf{3}} \mathbf{)}\right.\end{array}$ & $\begin{array}{c}\text { Melting } \\
\text { Point } \\
\left({ }^{\circ} \mathbf{C}\right)\end{array}$ & $\begin{array}{c}\text { Boiling } \\
\text { Point } \\
\left({ }^{\circ} \mathbf{C}\right)\end{array}$ & $\begin{array}{c}\text { Solubility } \\
(\mathbf{g} / \mathbf{1 0 0} \mathbf{g})\end{array}$ \\
\hline $\mathrm{BaO}_{2}$ & 169.3 & 4.96 & 450 & 800 & 1.5 \\
\hline $\mathrm{CaO}_{2}$ & 72.18 & 2.92 & 275 & & \\
\hline $\mathrm{H}_{2} \mathrm{O}_{2}$ & 34.0 & 1.46 & -0.43 & 152 & \\
\hline $\mathrm{Li}_{2} \mathrm{O}_{2}$ & 45.9 & 2.31 & $>195$ & & \\
\hline $\mathrm{MgO}_{2}$ & 56.3 & $\sim 3.0$ & 100 & & \\
\hline $\mathrm{Na}_{2} \mathrm{O}_{2}$ & 78.0 & 2.8 & 675 & & \\
\hline $\mathrm{SrO}_{2}$ & 119.6 & 4.78 & 215 & & 0.018 \\
\hline $\mathrm{UO}_{4} .2 \mathrm{H}_{2} \mathrm{O}$ & 338.1 & & $90-195$ & $>200$ & \\
\hline $\mathrm{ZnO}_{2}$ & 97.4 & 1.57 & $>150$ & 212 & \\
\hline
\end{tabular}

\subsubsection{Halogens and Metal Halogenates}

The halogen family of elements, as found on the periodic table, are fluorine $(F)$, chlorine $(\mathrm{Cl})$, bromine $(\mathrm{Br})$, iodine $(\mathrm{I})$, and astatine $(\mathrm{At})$. Although chloride is present in HLW only as an impurity, it has been hypothesized that chlorate can be produced during oxalic acid cleaning.

Since halogen compounds are highly soluble, most will be removed as part of bulk waste removal. Any remaining will most likely be restricted to those that react with silver, such as insoluble $\mathrm{AgCl}$ or $\mathrm{CCl}$. If the chloride or halogen becomes available and oxygenated, it will become highly soluble in water. In water, chlorine dioxide will decompose. Since it has been shown that even dry sludge contains significant interstitial liquid, concentration/accumulation will not occur. The solubility of $\mathrm{Cl}^{-}$ throughout the dissolution process is shown in Table 6-6. 
Table 6-6 Estimated Chloride Abundance During Acid Cleaning

\begin{tabular}{|c|c|c|c|c|}
\hline \multirow{2}{*}{ Stage } & \% Total & Aqueous & Vapor & Solid \\
\cline { 2 - 5 } & (\% mole) & \multicolumn{2}{|c|}{ (\% of initial mole) } \\
\hline Pre-bulk waste & 100 & 100 & NA & NA \\
\hline Initial & 100 & 100 & 0 & 0 \\
\hline $70 \%$ Dissolution & 100 & 85 & $<1 \mathrm{E}-1$ & 7.9 \\
\hline $50 \%$ Dissolution & 7.9 & 0.3 & 0 & 7.6 \\
\hline $30 \%$ Dissolution & 7.6 & 0.1 & 0 & 7.5 \\
\hline Supernate add* & 93 & 93 & 0 & 0 \\
\hline Caustic add & $\sim 93$ & $\sim 93$ & 0 & 0 \\
\hline
\end{tabular}

The increase in $\mathrm{Cl}^{-}$during the final two stages reflects the fact that normal tank farm supernate, to be added as part of restoring the $\mathrm{pH}$, has elevated soluble $\mathrm{Cl}^{-}$ compared to the initial sludge heel dissolution starting point.

lodine and the other halogens are fission products in spent fuel. Most are removed by scrubbing the off-gases from fuel dissolution. Silver iodide is removed from the saddles with acid flushes. A small amount of the fission product iodine is reduced to iodide, travels through fuel processing operations, and is received with the waste. The acidic solutions made alkaline with sodium hydroxide are sent to the tank farms.

Transfers of flushes from the iodine reactors to the tank farm were stopped in 1970's. Only small amounts of iodide have been added to the waste since 1970 (HLW, 2005). Additionally, a vast majority of the iodine in the tanks will remain soluble. Literature (Knovel, 2003) shows that the solubility is $29 \mathrm{~g} / \mathrm{L}$ at $25^{\circ} \mathrm{C}$ in water. Because of bulk waste removal, little iodine will remain within the tank for acid heel dissolution. Consequently, conditions within tank farm facilities prevent the production or accumulation of these compounds in sufficiently large enough quantities to be an explosion hazard. The iodine behavior can be better understood by spiking the material balance and tracking its fate as summarized in Table 6-7. 
Table 6-7 Estimated lodine Abundance During Acid Cleaning

\begin{tabular}{|c|c|c|c|c|}
\hline \multirow{2}{*}{ Stage } & $\begin{array}{c}\text { \% Total } \\
\text { (\% mole) }\end{array}$ & Aqueous & Vapor & Solid \\
\cline { 2 - 5 } & \multicolumn{3}{|c|}{ (\% of initial mole) } \\
\hline Pre-bulk waste & 100 & 100 & NA & NA \\
\hline Initial & 100 & 100 & 0 & 0 \\
\hline $70 \%$ Dissolution & 100 & 85 & $<1 \mathrm{E}-1$ & 7.9 \\
\hline $50 \%$ Dissolution & 7.9 & 0.3 & 0 & 7.6 \\
\hline $30 \%$ Dissolution & 7.6 & 0.1 & 0 & 7.5 \\
\hline Supernate add* & 93 & 93 & 0 & 0 \\
\hline Caustic add & $\sim 93$ & $\sim 93$ & 0 & 0 \\
\hline
\end{tabular}

The increase in I- during the final two stages reflects the fact that normal tank farm supernate, to be added as part of restoring the $\mathrm{pH}$, has elevated soluble I' compared to the initial sludge heel dissolution starting point.

Approximately $50 \mathrm{~kg}$ of silver was sent into Tank 13 from the flushing of silver-coated saddles from separations. This occurred between November 1969 and May 1970. From Tank 13, the waste was transferred into Tank 21, which was the $1 \mathrm{H}$ Evaporator Feed Tank. A total of about 2 million gallons of waste transferred into Tank 21 from Tank 13 during this period. A total of about 3 million gallons of waste was processed through the Evaporator, producing slightly less than 1 million gallons of concentrate in Tank 10. After cooling, approximately 30,000 gallons of saltcake crystallized. After cooling, the concentrated supernate was transferred from Tank 10 into Tanks 11, 14, and 16 [Cavin, 2003].

During May and the remainder of 1970, an effort was made to mix the concentrated silver-containing waste with other waste to dilute the silver content. Multiple waste transfers were made to Tanks 11,13,14, 15, and 16 to dilute the silver content. During this time, approximately 2 million gallons of waste, that contained only trace silver, was transferred into the $1 \mathrm{H}$ Evaporator system from the Receipt Basin for Offsite Fuels and Tank 12. In addition, the saltcake produced between November 1969 and May 1970 was dissolved and mixed with the other concentrated supernate [HLW, 2005]. 
For F-Area, the primary source of silver was the iodine reactors. From J uly 1956 to October 1970, a total of $300 \mathrm{~kg}$ of silver was transferred into Tank 7. No incidents of popping noises have ever been reported with waste transferred into this tank or processed through the $2 \mathrm{~F}$ evaporator. In the $\mathrm{H}$-Area part of the tank farm, the silver containing waste was diluted with other waste that contained no more than trace amounts of silver [Cavin, 2003] . The output of the O $\mathrm{LI}^{\odot}$ model, as shown in Table 68 , forecasts that as dissolution begins, all of the insoluble (post first-strike) $\mathrm{Cl}^{-}$ associated with the $\mathrm{Ag}^{+}$will form solids. Refer to Table 6-8.

Table 6-8 Silver and Chloride Ion Balance

\begin{tabular}{|c|c|c|c|c|}
\hline Ion & $\begin{array}{c}\text { Initial Aqueous } \\
\text { (mole) }\end{array}$ & $\begin{array}{c}\text { Initial Solid } \\
\text { (mole) }\end{array}$ & $\begin{array}{c}\text { Post Aqueous } \\
\text { (mole) }\end{array}$ & $\begin{array}{c}\text { Post Solid } \\
\text { (mole) }\end{array}$ \\
\hline $\mathrm{Ag}^{+}$ & 0.8 & 208.9 & 11.1 & 198.5 \\
\hline $\mathrm{Cl}^{-}$ & 4615.2 & 0.0 & 4416.9 & 198.5 \\
\hline
\end{tabular}

Although the results above do not preclude the formation of $\mathrm{AgCl}$, since the available silver is significantly less than that used in studies, and the chloride is predominately soluble, the possible formation of $\mathrm{AgCl}$ should be bound by that of the studies.

Halo-nitrogen compounds such as nitrogen tri-iodide \{i.e., $\mathrm{NI} 3 \cdot \mathrm{Hf}=-144 \mathrm{Kjoule} / \mathrm{mole}\}$ and nitrogen trichloride $\left\{\right.$ i.e., $\left.\mathrm{NCl}_{3}=+230 \mathrm{Kjoule} / \mathrm{mole}\right\}$, and halo-oxygen compounds such as chlorine dioxide \{i.e., $\left.\mathrm{ClO}_{2} \cdot \mathrm{Hf}=+100 \mathrm{Kjoule} / \mathrm{mole}\right\} \&$ dichloride heptaoxide \{.e., $\left.\mathrm{Cl}_{2} \mathrm{O}_{7} \cdot \mathrm{Hf}=+270 \mathrm{Kjoule} / \mathrm{mole}\right\}$ are known to be potentially explosive (KNOVEL, 2003). Nitrogen trichloride and nitrogen tri-iodide are formed by reacting an ammonium halide with a halogen gas [KNOVEL, 2003]. Traces of halogen gas must be present during chemical separations for these compounds to be formed. Gases expected from acid cleaning include primarily $\mathrm{CO}_{2}, \mathrm{H}_{2}$, potentially $\mathrm{NO}_{x}$, sulfates, and some low concentrations of acids. Since the halogen concentration is maintained very low and the tank vapor space is purged, any halogen gases would be quickly purged prior to building up to flammable concentrations. 
Dichloride heptaoxide $\left\{1 . e ., \mathrm{Cl}_{2} \mathrm{O}_{7} \cdot \mathrm{Hf}=+238 \mathrm{Kjoule} / \mathrm{mole}\right\}$ is normally produced by the dehydration of perchloric acid \{i.e., $\mathrm{HClO}_{4} \cdot \mathrm{Hf}=+8.36 \mathrm{Kjoule} / \mathrm{mole}$ \} [KNOVEL, 2003]. Perchlorates are not used as process chemicals at SRS, and the formation of appreciable amounts of perchlorates has been deemed not possible based on thermodynamics. Additionally, since even "dry sludge tanks" contained at least 50 vol\% interstitial liquid, dehydration of perchloric acid, if present, is highly unlikely. Therefore, oxalic acid dissolution does not increase the risk of halo-nitrogen and halo-oxygen explosive events.

\subsubsection{Metal Nitrides}

Metal nitrides of concern are primarily silver (e.g., $\mathrm{Ag}_{3} \mathrm{~N}$ ) and mercury nitrides (e.g. $\mathrm{HgN}$ ). As discussed previously, silver and mercury additions to the tank farm have been limited. The fate of nitrogen throughout the oxalic acid aided heel removal effort is detailed in Table 6-9.

Table 6-9 Estimated Nitride Abundance During Acid Cleaning

\begin{tabular}{|c|c|c|c|c|}
\hline \multirow{2}{*}{ Stage } & Total & Aqueous & Vapor & Solid \\
\cline { 2 - 5 } & (\% mole) & \multicolumn{3}{|c|}{ (\% of initial mole) } \\
\hline pre-bulk waste & 100 & 100 & NA & NA \\
\hline Initial & 100 & 100 & 0 & 0 \\
\hline $70 \%$ Dissolution & 100 & 99.9 & $<1 \mathrm{E}-1$ & 0 \\
\hline $50 \%$ Dissolution & 0 & 0 & 0 & 0 \\
\hline $30 \%$ Dissolution & 0 & 0 & 0 & 0 \\
\hline supernate add* & $\sim 5000$ & $\sim 5000$ & 0 & 0 \\
\hline caustic add & $\sim 5000$ & $\sim 5000$ & 0 & 0 \\
\hline
\end{tabular}

The increase in nitrides during the final two stages reflects the fact that normal tank farm supernate, to be added as part of restoring the $\mathrm{pH}$, has elevated nitrides compared to the initial sludge heel dissolution starting point. 
As seen in Table 6-9, any metal nitrides will quickly decrease during the oxalic acid aided heel removal effort, even potentially creating NOx emissions. The material balance, contained in Appendix 3, is additionally spiked to confirm that because of solubility, nitrides will quickly exit the system.

\subsubsection{Ammonia Compounds}

Based on the aging studies of organics and ammonia compounds and the process history, any ammonia compounds, precursors, or decomposition products should be long gone prior to acid being added to the tank. Nitrogen and hydrogen at elevated temperatures can produce ammonia, but most of the soluble nitrogen has been previously washed away. Ammonia concentrations and nitrides, post acid additions, are therefore not anticipated to exist in explosive quantities.

Additionally, it is important to note that ammonia salts are generally soluble. The solubility of ammonia in water at $25^{\circ} \mathrm{C}$ is about $77 \mathrm{mg} / \mathrm{L}$ at $1 \mathrm{~atm}$. Its boiling point is $33^{\circ} \mathrm{C}$, while its melting point is $-77.7^{\circ} \mathrm{C}$. Its heat of vaporization is $+23 \mathrm{Kjoule} / \mathrm{mole}$. Its auto ignition temperature is $104^{\circ} \mathrm{C}$. Its critical temperature of $133^{\circ} \mathrm{C}$ is easily exceeded in fires. The lower flammability limit is 16 vol\%, while the upper is $25 \%$ [Knovel, 2003].

A lingering presence of ammonia can be discounted since the $\mathrm{NH}_{4}$ would quickly evaporate based on partial pressure. Knovel [2003] estimates the partial pressures of ammonia (with $\mathrm{Na}^{+}=6.2 \mathrm{M}$ and $\mathrm{OH}^{-}=1.7 \mathrm{M}$; similar to routine non-evaporator system tank farm conditions) at various temperatures. R efer to Table 6-10. 
Table 6-10 Partial Pressures of Ammonia (with $6.2\left[\mathrm{Na}^{+}\right], 1.7\left[\mathrm{OH}^{-}\right]$)

\begin{tabular}{|c|c|c|c|c|c|}
\hline & \multicolumn{5}{|c|}{ Liquid Phase Ammonia Concentrations } \\
\hline Ammonia & 3.85 & 1.27 & 0.834 & 0.0841 & 0.0417 \\
\hline Ammonia & 3.54 & 1.14 & $7.43 \mathrm{E}-1$ & $7.43 \mathrm{E}-2$ & $3.68 \mathrm{E}-2$ \\
\hline Temp. $\left({ }^{\circ} \mathrm{C}\right)$ & $\mathbf{K}_{\mathbf{h}}$ & \multicolumn{4}{|c|}{ Partial Pressure of NH $_{\mathbf{4}}$ Vapor $(\mathbf{a t m})$} \\
\hline 25 & 23.91 & $1.48 \mathrm{E}-1$ & $4.75 \mathrm{E}-2$ & $3.11 \mathrm{E}-2$ & $1.54 \mathrm{E}-3$ \\
\hline 30 & 19.68 & $1.80 \mathrm{E}-1$ & $5.77 \mathrm{E}-2$ & $3.78 \mathrm{E}-2$ & $1.87 \mathrm{E}-3$ \\
\hline 40 & 13.56 & $2.61 \mathrm{E}-1$ & $8.38 \mathrm{E}-2$ & $5.48 \mathrm{E}-2$ & $2.72 \mathrm{E}-3$ \\
\hline 50 & 9.55 & $3.70 \mathrm{E}-1$ & $1.19 \mathrm{E}-1$ & $7.78 \mathrm{E}-2$ & $3.86 \mathrm{E}-3$ \\
\hline 56.96 & 7.68 & $4.61 \mathrm{E}-1$ & $1.48 \mathrm{E}-1$ & $9.68 \mathrm{E}-1$ & $4.80 \mathrm{E}-3$ \\
\hline 70 & 5.02 & $7.05 \mathrm{E}-1$ & $2.26 \mathrm{E}-1$ & $1.48 \mathrm{E}-1$ & $7.34 \mathrm{E}-3$ \\
\hline
\end{tabular}

Where $K_{h}$ represents Henry's Law Constant

It has been estimated that up to $90 \mathrm{wt} \%$ of ammonia would be from the decomposition of the hydrazine \{i.e., $\mathrm{N}_{2} \mathrm{H}_{4} \cdot \mathrm{Hf}=+149$ Kjoule/mole $\}$ and hydroxylamine $\left\{\right.$ i.e., $\mathrm{NH}_{3} \mathrm{O} \cdot \mathrm{Hf}=-114 \mathrm{Kjoule} /$ mole $\}$ which entered the tank farms from the separations process [Britt, 2003:32]. Besides ammonia, ammonium nitrate \{i.e., $\mathrm{NH}_{4} \mathrm{NO}_{3} \cdot \mathrm{Hf}=-184$ Kjoule/mole\}, ammonium nitrite \{i.e., $\mathrm{NH}_{4} \mathrm{NO}_{2} \cdot \mathrm{Hf}=+116$ Kjoule/mole\}, and ammonia/air mixtures are well-documented explosive compounds [Knovel, 2003]. In the separation facilities, hydrazine and hydroxylamine are used as chemical reductants (i.e., materials that accept electrons). During processing, excess hydrazine and hydroxylamine are destroyed by chemical reactions with nitrate and nitrite. Both hydrazine \& hydroxylamine are considered soluble. The solubility for hydrazine and hydroxylamine (in water at $25^{\circ} \mathrm{C}$ ) is shown in Table 6-11 [Knovel, 2003).

Table 6-11 Properties of Hydrazine and Hydroxylamine (in Water)

\begin{tabular}{|c|c|c|c|c|c|}
\hline Formula & $\begin{array}{c}\text { Specific } \\
\text { Gravity }\end{array}$ & $\begin{array}{c}\text { Melting } \\
\text { Point }\end{array}$ & $\begin{array}{c}\text { Boiling } \\
\text { Point }\end{array}$ & $\begin{array}{c}\text { Solubility in } \\
\text { 0-C water }\end{array}$ & $\begin{array}{c}\text { Solubility } \\
\text { (g/100g })\end{array}$ \\
\hline $\mathrm{N}_{2} \mathrm{H}_{4}$ & 1.01 & 1.4 & 113.5 & $\begin{array}{c}\text { soluble in all } \\
\text { proportions }\end{array}$ & $\begin{array}{c}\text { soluble in all } \\
\text { proportions }\end{array}$ \\
\hline $\mathrm{NH}_{2} \mathrm{OH}$ & 1.358 & 34 & $\begin{array}{c}56.5 \mathrm{Hg} \\
\mathrm{mm}\end{array}$ & $\mathrm{NH}_{2} \mathrm{OH}$ & 33.03 \\
\hline
\end{tabular}

Hydrazine can be dissolved with oxygen as shown in Reaction 6-3. 


$$
\mathrm{N}_{2} \mathrm{H}_{4}+\mathrm{O}_{2} \ddagger 2 \mathrm{H}_{2} \mathrm{O}+\mathrm{N}_{2}
$$

Hydrazine, however, has two possible ways to produce a significant amount of ammonia as shown below in Reactions 6.4 and 6.5.

$$
\begin{array}{ll}
3 \mathrm{~N}_{2} \mathrm{H}_{4} \neq 4 \mathrm{NH}_{3}+\mathrm{N}_{2} & \text { (Reaction 6-4) } \\
2 \mathrm{~N}_{2} \mathrm{H}_{4} \neq \mathrm{H}_{2}+\mathrm{N}_{2}+2 \mathrm{NH}_{3} & \text { (Reaction 6-5) }
\end{array}
$$

Hydroxylamine possible reaction pathways are $\mathrm{pH}$ dependent. In an alkaline solution, the reaction pathway is shown in Reaction 6-6 [Hobbs, 1999:29].

$$
3 \mathrm{NH}_{3} \mathrm{O} \neq \mathrm{NH}_{3}+\mathrm{N}_{2}+3 \mathrm{H}_{2} \mathrm{O}
$$

In an acidic solution, the hydroxylamine reaction pathway is shown in Reaction 6-7.

$$
4 \mathrm{NH}_{3} \mathrm{O} \neq \mathrm{N}_{2} \mathrm{O}+2 \mathrm{NH}_{3}+3 \mathrm{H}_{2} \mathrm{O}
$$

Hydrolysis and radiolysis of the hydrazine and hydroxylamine can also indirectly produce various gases including NOx gases, nitrogen, ammonia and even hydrogen gas. Since hydrazine and hydroxylamine are mostly volatized with the partial pressure of hydrazine at roughly $0.066 \mathrm{~atm}$, the precursor, $\mathrm{Ag}\left(\mathrm{NH}_{3}\right)_{2}$, most likely could not be created with the normal ammonia decay [Hobbs, 2002:31].

\subsubsection{Organics}

The possible miscellaneous organics and chemicals introduced into Tanks 1-15 have been previously shown in Table 6-3. Because of the age of both the supernate and sludge contained in Tanks 1-15, volatile organics would have long ago decomposed [Britt, 2003:5]. A review of the SRNL analysis of samples demonstrates that the concentrations of volatile organics, along with hydrogen and $\mathrm{NH}_{3}$, do not pose a flammability hazard [Britt, 2003]. With all factors being equal, since the waste in 
Tanks 1-15 has been aged since the 1980's, it can be ascertained that even with acid treatment of Tanks 1-15, there will be a lower risk of explosion than that currently accepted.

Since oxalic acid is also an organic, its net effect should also be considered. Since the heat of formation for oxalic acid is $-822 \mathrm{Kjoule} / \mathrm{mole}$, while for sodium oxalate the heat of formation is $-1318 \mathrm{Kjoule} / \mathrm{mole}$ (Knovel, 2003), one could predict that both would not have a significant impact on energetics. The energy of combustion and the energy of formation for the Tanks 1-15 organics are shown in Table 6-12.

Table 6-12 Heat of Combustion/Formation for Organics

\begin{tabular}{|c|c|c|c|}
\hline Constituent & Formula & $\begin{array}{c}\text { Heat of } \\
\begin{array}{c}\text { Combustion } \\
\text { (Kjoule/ } \\
\text { mole) }\end{array} \\
\end{array}$ & $\begin{array}{c}\text { Heat of } \\
\text { Formation } \\
\text { (Kjoule/ } \\
\text { mole) }\end{array}$ \\
\hline \multirow{12}{*}{$\begin{array}{c}\text { oxalic acid } \\
\text { dodecane } \\
\text { tri-n-butyl phosphate } \\
\text { (tributyl phosphate) } \\
\text { di-n-butyl phosphate } \\
\text { mono-n-butyl phosphate } \\
\text { n-butanol } \\
\text { gluconic acid } \\
\text { ascorbic acid } \\
\text { in-exchange resins } \\
\text { polydimethylsiloxane } \\
\text { hydrogenated tallow } \\
\text { glycerides } \\
\text { ethylene glycol (1,2- } \\
\text { ethanediol) } \\
\text { methylcellulose } \\
\text { 2,4,7,9-tetramethyl-5- } \\
\text { decyne-4,7-diol }\end{array}$} & $(\mathrm{COOH})_{2}$ & \multirow{5}{*}{$\begin{array}{c}119 \\
7514\end{array}$} & \multirow{5}{*}{$\begin{array}{l}-822 \\
+28.1\end{array}$} \\
\hline & $\mathrm{C}_{12} \mathrm{H}_{26}$ & & \\
\hline & $\left(\mathrm{CH}_{3}\left[\mathrm{CH}_{2}\right]_{3} \mathrm{O}\right)_{3} \mathrm{PO}$ & & \\
\hline & $\mathrm{C}_{8} \mathrm{H}_{18} \mathrm{O}_{4} \mathrm{P}_{1}(1$ neg. charge $)$ & & \\
\hline & $\mathrm{C}_{4} \mathrm{H}_{9} \mathrm{O}_{4} \mathrm{P}_{1}(2$ neg charge $)$ & & \\
\hline & $\mathrm{C}_{4} \mathrm{H}_{10} \mathrm{O}$ & \multirow[t]{2}{*}{2456} & \multirow{2}{*}{-2746} \\
\hline & $\mathrm{C}_{6} \mathrm{H}_{12} \mathrm{O}_{7}$ & & \\
\hline & $\mathrm{C}_{6} \mathrm{H}_{8} \mathrm{O}_{7}$ & \multirow[t]{2}{*}{4219} & \multirow{3}{*}{$\begin{array}{l}-587 \\
-731 \\
+213\end{array}$} \\
\hline & 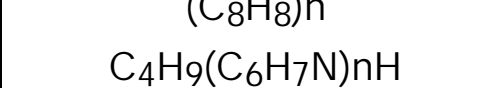 & & \\
\hline & $\left(\mathrm{C}_{2} \mathrm{H}_{6} \mathrm{OSi}\right) \mathrm{n}$ & \multirow{3}{*}{1058} & \\
\hline & $\begin{array}{c}\mathrm{NA} \\
\mathrm{C}_{2} \mathrm{H}_{6} \mathrm{O}_{2}\end{array}$ & & \multirow[t]{2}{*}{-304} \\
\hline & $\begin{array}{c}\mathrm{CH}_{4} \mathrm{O} \times \text { Unspecified } \\
\text { Siloxanes }\end{array}$ & & \\
\hline
\end{tabular}

As seen in Table 6-12, dodecane has the largest heat of combustion/lowest positive heat of formation. Dodecane, because of its very low vapor pressure $\{0.33 \mathrm{mmHg}$ at $20^{\circ} \mathrm{C}$, is removed by separation evaporators prior to its discharge to HLW. Based on the modeling of evaporation of organic liquids, any paraffin that reaches the tank farm will persist in the tank farms for less than a few months [Ketusky, 2003]. Since Tanks 1-15 have not received fresh waste since the mid 1980's, any dodecane or 
volatile decomposition products are considered to have long ago evaporated.

Tri-n-butyl phosphate could hypothetically reach the tank farm dissolved or entrained in the aqueous waste. Any TBP that reaches alkaline tanks would have been slowly hydrolyzed by the following reactions [Hobbs, 1999].

$$
\begin{aligned}
& \left(\mathrm{C}_{4} \mathrm{H}_{9} \mathrm{O}\right)_{3} \mathrm{PO}+\mathrm{OH}^{-} \neq\left(\mathrm{C}_{4} \mathrm{H}_{9} \mathrm{O}\right)_{2} \mathrm{PO}_{2}{ }^{-}+\mathrm{C}_{4} \mathrm{H} 9 \mathrm{OH} \\
& \left(\mathrm{C}_{4} \mathrm{H}_{9} \mathrm{O}\right)_{2} \mathrm{PO}_{2}^{-}+\mathrm{OH}^{-} \neq\left(\mathrm{C}_{4} \mathrm{H}_{9} \mathrm{O}\right) \mathrm{PO}_{3}{ }^{-2}+\mathrm{C}_{4} \mathrm{H} 9 \mathrm{OH} \\
& \left(\mathrm{C}_{4} \mathrm{H}_{9} \mathrm{O}\right)_{2} \mathrm{PO}_{3}{ }^{-2}+\mathrm{OH}^{-} \neq \mathrm{PO}_{4}^{-3}+\mathrm{C}_{4} \mathrm{H}_{9} \mathrm{OH}
\end{aligned}
$$

Hydrolysis and radiolysis of the TBP produces di-n-butyl phosphate \{i.e., $\left.\left(\mathrm{C}_{8} \mathrm{H}_{19} \mathrm{O}_{4}\right) \mathrm{PO}\right\}$, mono-n-butyl phosphate $\left\{1 . e .,\left(\mathrm{C}_{4} \mathrm{H}_{10} \mathrm{O}_{4}\right) \mathrm{P}\right\}$, as well as carbon dioxide and inorganic phosphates. N-butanol is also a decomposition product of TBP. Because of the age of the wastes, any remaining TBP or volatile decomposition products are considered to have mostly evaporated and would not affect Tanks 1-15 [B ritt, 2003].

Gluconic acid \{i.e., $\mathrm{C}_{6} \mathrm{H}_{12} \mathrm{O}_{7} \cdot \mathrm{Hf}=1587 \mathrm{Kjoule} / \mathrm{mole}$ \} was used briefly in the separation facilities during the late 1950's, and has not been used since that time. Ascorbic acid, \{1.e., $\left.\mathrm{C}_{3} \mathrm{H}_{8} \mathrm{O}_{6} \cdot \mathrm{Hf}=-731 \mathrm{Kjoule} / \mathrm{mole}\right\}$, is sometimes still used in the separation facilities for actinide valence adjustment. Gluconic \& ascorbic acids hydrolyze rapidly in both acidic and basic solutions. Hydrolysis products include oxalic acid \{i.e., $\left.(\mathrm{COOH})_{2} \bullet \mathrm{Hf}=-822 \mathrm{Kjoule} / \mathrm{mole}\right\}$ and smaller organic acids. Further hydrolytic and radiolytic reactions with the organic acids produce various gasses including carbon dioxide (Knovel, 2003). Based on the age of the wastes in Tanks 115, any gluconic or ascorbic acids introduced into the tanks, as well as any associated decomposition products, are considered to have decomposed long ago.

Both anion and cation ion exchange resins were historically used in the separation facilities. Most of the resins contained polymeric backbones made of polystyrene and/or styrene-di-vinylbenzene co-polymers. Process records show that the majority 
of the resins were definitively digested in alkaline permanganate prior to being transferred to the tank farms. About $15 w t \%$ of the resins, however, may have been sent to the tank farms in the undigested form [Britt, 2003:32]. The permanganate digestion breaks down the resin into short chains that contain alcohol and carboxylic acid \{i.e., $\mathrm{COOH}\}$. Depending on the length of the chain, the resulting fragments may be soluble in aqueous solution. Radiolysis will also contribute to the breakdown of the resins, eventually forming small organic molecules of hydrogen, carbon dioxide, and ammonia [Camaioni, 1999). Based on the age of the wastes in Tanks $1-15$, any resin introduced into the tanks is considered to have decomposed and no longer represents an explosive hazard.

As previously discussed, vapor and liquid samples were taken from $\mathrm{H}$-Area Pump Tank (HPT)-5 \& F Area and F-Area Pump Tank (FPT)-3, as well as HLW Tanks 38, $43,26,33$ and 46. Vapor samples, taken from the pump tanks, exhibited trace amounts of organics that were several orders of magnitude below levels that could potentially represent flammability concerns. These liquid samples were taken at/and below the surface of the waste [Swingle, 1999:1]. Vapor sampling revealed that for Tanks 1-15 organic explosives are not considered a potential flammability concern.

Red oil is produced when organics enter vessels containing uranyl nitrate solutions that are heated to relatively high temperatures [Robinson, 2003:3-3]. Based on industry locations where red oil has been found, the organic materials are generally TBP, diluents, and associated decomposition products. Since red oil is not explosive at temperatures less than $130^{\circ} \mathrm{C}$, and the sludge temperature during heel removal will be maintained at less than $100^{\circ} \mathrm{C}$, red oil does not pose an explosive concern [Robinson, 2003:3.3].

High Level Waste stored at SRS contains only small amounts of organic compounds. Based on the process records of organic compounds received in the tank farms through 1984, a Total Organic Carbon (TOC) concentration in the waste, assuming a perfect blend, is calculated to be about 2,000 ppm (Britt, 2003). The actual concentration, however, is much lower than this due to radiolytic and chemical decomposition. Analysis of two active current sludge tanks closest to the organic processes indicated a (TOC) total organic carbon content of about $85 \mathrm{ppm}$ and 220 
ppm. The TOC in Tanks 1-15, considering the more than 20 years of aging, will be significantly less [B ritt, 2003].

\subsubsection{Hydrogen}

Hydrogen is generated either radiolytically or chemically. For the HLW tanks, radiolytic hydrogen generation rate, $X$, is calculated using Equation 6-3 [Davis, 2004, p3].

$$
X=\underline{R} \underline{B} / \underline{G} \underline{H} \frac{H / G}{10^{6}}+\underline{R}_{a} \underline{H} \underline{H}
$$

Where:

$$
\begin{aligned}
& R_{B / G}=\text { hydrogen generated per } 10^{6} \text { BTU of heat added from beta or gamma } \\
& H_{B / G}=\text { heat generated by beta and gamma decay } \\
& R_{a}=\text { hydrogen generated per } 10^{6} \text { BTU of heat added from alpha decay } \\
& H_{a}=\text { heat generated by alpha decay }
\end{aligned}
$$

The values $R_{B / G}$ and $R_{a}$ are dependent on the concentration of nitrate and nitrite in the waste and are given by Equation 6-4 and Equation 6-5.

$$
\begin{array}{r}
\mathrm{R}_{\mathrm{a}}=134.7-82.3\left(\mathrm{NO}_{\text {eff }}\right)^{1 / 3}-13.6\left(\mathrm{NO}_{\text {eff }}\right)^{2 / 3}+11.8\left(\mathrm{NO}_{\text {eff }}\right) \\
\mathrm{R}_{\mathrm{B} / \mathrm{G}}=48.36-52.78\left(\mathrm{NO}_{\text {eff }}\right)^{1 / 3}+14.1\left(\mathrm{NO}_{\text {eff }}\right)^{2 / 3}+0.572\left(\mathrm{NO}_{\text {eff }}\right)
\end{array}
$$

Where:

$$
\begin{aligned}
& \mathrm{NO}_{\text {eff }}=\text { the nitrate concentration plus } 1 / 2 \text { the nitrite concentration [Davis: } \\
& \text { 2004:3] }
\end{aligned}
$$

Since nitrates and nitrites are very soluble \{i.e., $\mathrm{NaNO}_{2}$ has a solubility of about $85 \mathrm{~g} / 100 \mathrm{~g}$ water at $25^{\circ} \mathrm{C}$, while $\mathrm{NaNO}_{3}$ has a solubility of about $90 \mathrm{~g} / 100 \mathrm{~g}$ of water at 
$25^{\circ} \mathrm{C}$ \}, they will largely be washed out as part of bulk waste removal (prior to the actual oxalic acid additions). Since the solubilities for $\mathrm{NO}_{3}$ and $\mathrm{NO}_{2}$ are very similar,

the detailed OLI Stream Analyzer ${ }^{\circ}$ outputs can be used to estimate the decrease of any initial nitrates or nitrites contained in the in material balance. Table 6-4 contained in Section 6.3.1 show the relative percent decrease in $\mathrm{NO}_{2}^{-1}$ and $\mathrm{NO}_{3}{ }^{-1}$ as part of cleaning the tank.

As discussed in Chapter 5, under acidic conditions, corrosion of the carbon steel tank is postulated to become the overwhelming source of hydrogen, masking the increase from the nitrate and nitrite reduction. Since the hydrogen from acid induced corrosion currently is not considered in the safety analyses, changes will be required to the basis to ensure that the risk does not increase.

\subsection{Conclusion on Energetic Compounds}

Hydrogen will effectively show an increased generation rate as part of the oxalic acid aided heel removal effort. Hydrogen is evaluated under the safety analyses (DSA, 2003:3-1] and as part of the revision to allow oxalic acid aided heel removal, corrosion induced hydrogen will have to be evaluated and be shown to be acceptable. No other increase in energetic compounds is expected. 


\section{DOWNSTREAM PROCESSABILITY}

\subsection{Introduction to Downstream Processability}

OLI ESP ${ }^{\odot}$, an integrated HLW process flowsheet, is constructed to simulate the dissolution of a 5000 gallon heel sludge. Chapter 5 focuses on treatment tank and $\mathrm{pH}$ adjustment tank safety analyses concerns, and hence, uses hypothetical worstcase sludge to bound any potential concerns. This chapter focuses on the downstream processability concerns, and hence uses representative sludge slurry. In this chapter, the processing preference for two different cases is also determined. The two cases are as follows:

1) Determine if effluent from heel dissolution process should be added to a washed sludge batch for DWPF feed (vitrification) instead of an unwashed sludge batch.

2) Determine if the dissolved sludge heel can be $\mathrm{pH}$ adjusted with existing waste supernate instead of fresh sodium hydroxide.

For the purposes of Chapter 7, the Tank 1-15 heel dissolution process has the following refinements:

- Tank 8 and Tank 11 characterization data from the process database are used.

- Water is added to establish operating heights.

- $\mathrm{pH}$ adjusted spent acid/excess acid are decanted to the evaporator feed or drop tank.

- The $\mathrm{pH}$ adjustment tank will be mixed to suspend solids.

- The resultant sodium oxalate is transferred to the DWPF sludge wash tank. 
The flow diagram is divided into segments with process models. The unique heel removal portion of the flowsheet shown in Figure 7-1 includes streams 1-4, 6-8, and 13. The flow diagram is also divided into the following segments:

- Heel Removal

- Sludge Washing

- Tank Farm Evaporation

- Salt Dissolution

Existing evaporator process [Hang, 2002; Koffman, 2002] and sludge washing models [Lillistan, 2004] are used to model the respective portions of the flowsheet. 0 ther process effects are calculated separately and are included in this analysis.

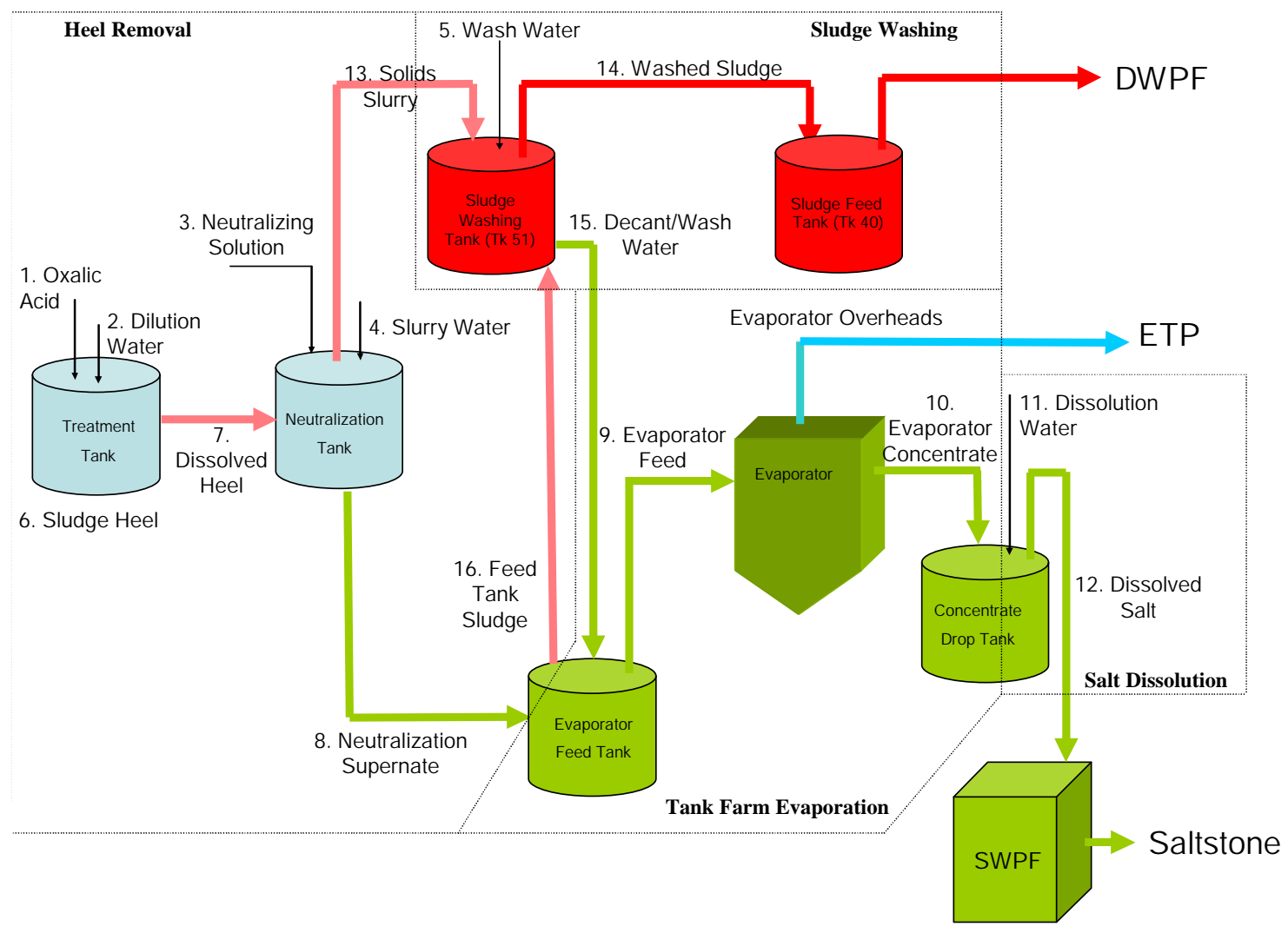

Figure 7-1 Sludge Heel Removal Process Diagram

\subsection{Sodium Oxalate Solubility}

The primary material formed using oxalic acid to clean the waste tanks has been determined to be metal oxalates and sodium oxalate. Figure 7-2 shows measured 
solubility of sodium oxalate for both simulants and HLW [Fowler, 1980; Wiley, 1978]. The figure also shows the results of several other solubility estimation methods [Kilpatrick, 1984].

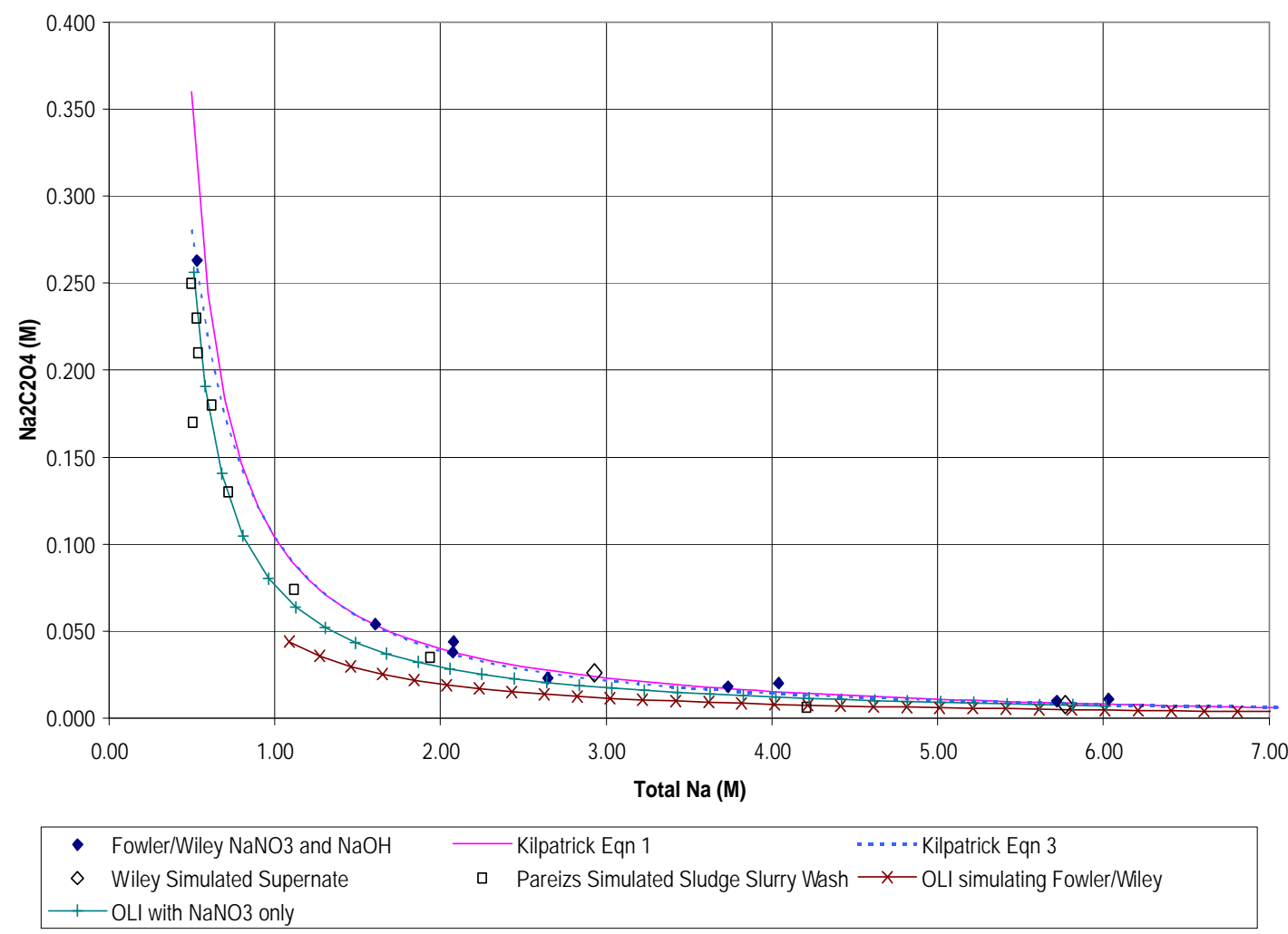

Figure 7-2 Oxalate Solubility Curve as a Function of Sodium Concentration

In Figure 7-2, the supernate simulants, containing only sodium nitrate and sodium hydroxide, used by Fowler and Wiley, are represented in solid symbols. The open symbols represent more complex multi-component supernate simulants. The lines represent various estimation methods. Two empirical data fits by Kilpatrick are shown, as well as two forecasts using $\mathrm{OLI}^{\circledR}$. The results indicate that the $\mathrm{OLI}^{\circledR}$ based model slightly under-predicts oxalate solubility.

\subsection{Sludge Heel Removal}

The sludge heel dissolution process assumes that the tank has completed bulk sludge removal, and as a result underwent significant washing. The remaining heel in the treated tank is no greater than 5,000 gallons of sludge slurry, which equates to roughly 2 inches of sludge slurry in Tanks 1-15. In addition, bulk sludge removal 
uses inhibited water to establish the minimum operating level. This ensures that minimal soluble salts are present in the heel. Inhibited water in the process minimally consists of 0.01 to $1 \mathrm{M} \mathrm{NaOH}$ and $0.011 \mathrm{M} \mathrm{NaNO}_{3}$, which results in about $0.02 \mathrm{M}$ to $0.03 \mathrm{M}$ total sodium salts. The heel, therefore, consists primarily of sludge solids and water with no more than $0.1 \mathrm{M}$ of soluble sodium salts.

The sludge solids composition for waste Tanks 1-15 is taken from the process database [HLW, 2005]. Since representative sludge is used in this chapter, only the composition is important, not the total amount of material in each tank. For this chapter it is reasoned that the relative percentage of each type of waste sent to the waste tank will more accurately reflect composition of the heel. The process database reports the waste type and monthly amount of waste transferred to each tank. Table 7-1 shows the totals of each type and relative percentage sent to each tank. Table 7-2 shows the composition by waste type. Table 7-3 shows the resulting composition of the sludge heel for each tank by combining the information in Tables 7-1 and 7-2. Note that the sludge composition includes some soluble sodium salts. The planned initial heel removal includes substantial water contact with the heel that will reduce the soluble salts to much lower amounts. These salts, however, are left in the estimated composition to conservatively estimate the consumption of acid during dissolution.

\begin{tabular}{|c|c|c|c|c|c|c|c|}
\hline Table 7- & \multicolumn{3}{|c|}{ Purex Sludge } & \multicolumn{3}{c|}{ HM } \\
\hline \multirow{2}{*}{ Stream } & Low & Mixed & High & Low & Mixed & High \\
\cline { 2 - 7 } & \multicolumn{7}{|c|}{ (wt \%) } \\
\hline 1 & 15.2 & 47.1 & 37.7 & 0 & 0 & 0 \\
\hline 2 & 0 & 100 & 0 & 0 & 0 & 0 \\
\hline 3 & 0 & 100 & 0 & 0 & 0 & 0 \\
\hline 4 & 0 & 6.1 & 93.9 & 0 & 0 & 0 \\
\hline 5 & 0 & 67.2 & 32.8 & 0 & 0 & 0 \\
\hline 6 & 0 & 0 & 100 & 0 & 0 & 0 \\
\hline 7 & 79.4 & 16.3 & 4.2 & 0 & 0 & 0 \\
\hline 8 & 70.6 & 14.6 & 14.8 & 0 & 0 & 0 \\
\hline 9 & 0 & 100 & 0 & 0 & 0 & 0 \\
\hline 10 & 0 & 98.3 & 0 & 0 & 1.7 & 0 \\
\hline 11 & 6.3 & 0 & 0 & 25.9 & 2.7 & 65.2 \\
\hline 12 & 0 & 16.9 & 0 & 0 & 0 & 83.1 \\
\hline 13 & 12 & 13.1 & 3.3 & 57.4 & 2.1 & 12.1 \\
\hline 14 & 0 & 0 & 58.7 & 24.9 & 0 & 16.4 \\
\hline 15 & 0 & 0 & 0 & 8.7 & 33.1 & 58.1 \\
\hline
\end{tabular}


Table 7-2 Composition of Sludge Solids by Waste Type

\begin{tabular}{|c|c|c|c|c|c|c|}
\hline \multirow{3}{*}{ Constituent } & \multicolumn{3}{|c|}{ HM } & \multicolumn{3}{|c|}{ Purex } \\
\hline & High & Low & Mixed & High & Low & Mixed \\
\hline & \multicolumn{6}{|c|}{$(w t \%)$} \\
\hline $\mathrm{Al}(\mathrm{OH})_{3}$ & 67 & 20.6 & 62.0 & 6.50 & 13.9 & 11.4 \\
\hline $\mathrm{CaC}_{2} \mathrm{O}_{4}$ & 2.2 & 0.0 & 1.9 & 0.0 & 0.0 & 0.0 \\
\hline $\mathrm{CaCO}_{3}$ & 0.0 & 4.6 & 0.5 & 2.8 & 5.5 & 4.5 \\
\hline $\mathrm{Ce}(\mathrm{OH})_{3}$ & 0.1 & 1.2 & 0.2 & 0.3 & 0.4 & 0.3 \\
\hline $\mathrm{Fe}(\mathrm{OH})_{3}$ & 10.2 & 46.0 & 14.1 & 48.5 & 48.0 & 48.2 \\
\hline $\mathrm{HgO}$ & 3.0 & 2.2 & 2.9 & 0.2 & 0.1 & 0.1 \\
\hline $\mathrm{MnO}_{2}$ & 2.6 & 11.8 & 3.6 & 12.1 & 4.2 & 6.9 \\
\hline $\mathrm{NaCl}$ & 0.0 & 1.4 & 0.2 & 0.2 & 2.1 & 1.4 \\
\hline $\mathrm{NaNO}_{3}$ & 3.3 & 0.4 & 2.9 & 1.3 & 1.6 & 1.5 \\
\hline $\mathrm{NaOH}$ & 1.4 & 3.3 & 1.6 & 5.1 & 4.7 & 4.8 \\
\hline $\mathrm{Ni}(\mathrm{OH})_{2}$ & 1.0 & 0.7 & 1.0 & 5.8 & 3.5 & 4.3 \\
\hline $\mathrm{SiO}_{2}$ & 4.7 & 0.0 & 4.2 & 1.0 & 1.9 & 1.6 \\
\hline $\mathrm{ThO}_{2}$ & 1.3 & 0.1 & 1.2 & 0.1 & 0.0 & 0.0 \\
\hline $\mathrm{UO}_{2}(\mathrm{OH})_{2}$ & 1.3 & 4.7 & 1.6 & 10.9 & 7.8 & 8.9 \\
\hline Total & 97.9 & 97.0 & 97.8 & 94.8 & 93.4 & 93.9 \\
\hline
\end{tabular}


Plutonium and Strontium considered in HWCS are a very small fraction of the total waste and are not considered in evaluating downstream processability.

Table 7-3 Estimated Composition of Sludge Solids in Tank Heels

\begin{tabular}{|c|c|c|c|c|c|c|c|c|c|c|c|c|c|c|c|}
\hline \multirow{3}{*}{ 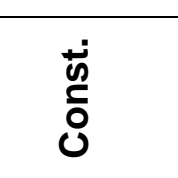 } & \multicolumn{15}{|c|}{ Tank } \\
\hline & 1 & 2 & 3 & 4 & 5 & 6 & 7 & 8 & 9 & 10 & 111 & 12 & 13 & 14 & 15 \\
\hline & \multicolumn{15}{|c|}{ (wt \%) } \\
\hline $\mathrm{Al}(\mathrm{OH})_{3}$ & 11 & 12 & 12 & 7 & 10 & 7 & 14 & 13 & 12 & 13 & 53 & 59 & 25 & 20 & 63 \\
\hline $\mathrm{CaC}_{2} \mathrm{O}_{4}$ & 0 & 0 & 0 & 0 & 0 & 0 & 0 & 0 & 0 & 0 & 1.5 & 1.8 & 0.3 & 0.4 & 1.9 \\
\hline $\mathrm{CaCO}_{3}$ & 4.3 & 4.8 & 4.8 & 3.0 & 4.2 & 2.9 & 5.5 & 5.3 & 4.8 & 4.7 & 1.6 & 0.8 & 4.1 & 2.9 & 0.6 \\
\hline $\mathrm{Ce}(\mathrm{OH})_{3}$ & 0.3 & 0.3 & 0.3 & 0.3 & 0.3 & 0.3 & 0.4 & 0.4 & 0.3 & 0.3 & 0.4 & 0.1 & 0.8 & 0.5 & 0.2 \\
\hline $\mathrm{Fe}(\mathrm{OH})_{3}$ & 51 & 51 & 51 & 51 & 51 & 51 & 51 & 51 & 51 & 51 & 23 & 17 & 43 & 44 & 15 \\
\hline $\mathrm{HgO}$ & 0.2 & 0.1 & 0.1 & 0.2 & 0.2 & 0.3 & 0.1 & 0.1 & 0.1 & 0.2 & 2.7 & 2.6 & \begin{tabular}{|l|}
1.7 \\
\end{tabular} & 1.2 & 3.0 \\
\hline $\mathrm{MnO}_{2}$ & 9.0 & 7.4 & 7.4 & 12 & 9.1 & 13 & 5.3 & 6.2 & 7.4 & 7.3 & 5.3 & 3.5 & 9.3 & 11 & 3.8 \\
\hline $\mathrm{NaCl}$ & 1.1 & 1.5 & 1.5 & 0.3 & 1.1 & 0.2 & 2.0 & 1.8 & 1.5 & 1.5 & 0.5 & 0.3 & 1.3 & 0.5 & 0.2 \\
\hline $\mathrm{NaNO}_{3}$ & 1.5 & 1.6 & 1.6 & 1.4 & 1.5 & 1.4 & 1.7 & 1.6 & 1.6 & 1.6 & 2.4 & 3.0 & 1.1 & 1.5 & 3.0 \\
\hline $\mathrm{NaOH}$ & 5.2 & 5.1 & 5.1 & 5.3 & 5.2 & 5.4 & 5.1 & 5.1 & 5.1 & 5.1 & 2.1 & 2.0 & 3.6 & 4.2 & 1.6 \\
\hline $\mathrm{Ni}(\mathrm{OH})_{2}$ & 5.0 & 4.5 & 4.5 & 6.0 & 5.0 & 6.1 & 3.9 & 4.2 & 4.5 & 4.5 & 1.1 & 1.6 & 1.8 & 3.9 & 1.0 \\
\hline $\mathrm{SiO}_{2}$ & 1.5 & 1.7 & 1.7 & 1.1 & 1.5 & 1.0 & 1.9 & 1.8 & 1.7 & 1.7 & 3.4 & 4.3 & 1.2 & 1.4 & 4.2 \\
\hline $\mathrm{ThO}_{2}$ & 0.0 & 0.0 & 0.0 & 0.1 & 0.0 & 0.1 & 0.0 & 0.0 & 0.0 & 0.1 & 0.9 & 1.1 & 0.3 & 0.3 & 1.2 \\
\hline $\begin{array}{l}\mathrm{UO}_{2} \\
(\mathrm{OH})_{2}\end{array}$ & 10 & 9.4 & 9.4 & 11 & 10 & 12 & 8.6 & 9.0 & 9.4 & 9.3 & 2.7 & 2.7 & 5.6 & 8.2 & 1.7 \\
\hline Total & & & & & & & & & & & & & & & \\
\hline
\end{tabular}


Table 7-4 Estimated Composition of Sludge Slurry in Tank Heels

\begin{tabular}{|c|c|c|c|c|c|c|c|c|c|c|c|c|c|c|c|}
\hline \multirow{3}{*}{ 苟 } & \multicolumn{15}{|c|}{ Tank } \\
\hline & 1 & 2 & 3 & 4 & 5 & 6 & 7 & 8 & 9 & 10 & 11 & 12 & 13 & 14 & 15 \\
\hline & \multicolumn{15}{|c|}{ (wt\%) } \\
\hline $\mathrm{Al}(\mathrm{OH})_{3}$ & 4.2 & 4.8 & 4.8 & 2.9 & 4.1 & 2.7 & 5.6 & 5.3 & 4.8 & 5.2 & 21 & 24 & 10 & 8.2 & 25.0 \\
\hline $\mathrm{CaC}_{2} \mathrm{O}_{4}$ & 0.0 & 0.0 & 0.0 & 0.0 & 0.0 & 0.0 & 0.0 & 0.0 & 0.0 & 0.0 & 0.6 & 0.7 & 0.1 & 0.1 & 0.8 \\
\hline $\mathrm{CaCO}_{3}$ & 1.7 & 1.9 & 1.9 & 1.2 & 1.7 & 1.2 & 2.2 & 2.1 & 1.9 & 1.9 & 0.6 & 0.3 & 1.7 & 1.2 & 0.2 \\
\hline $\mathrm{Ce}(\mathrm{OH})_{3}$ & 0.1 & 0.1 & 0.1 & 0.1 & 0.1 & 0.1 & 0.1 & 0.1 & 0.1 & 0.1 & 0.2 & 0.0 & 0.3 & 0.2 & 0.1 \\
\hline $\mathrm{Fe}(\mathrm{OH})_{3}$ & 21 & 21 & 21 & 21 & 21 & 21 & 21 & 21 & 21 & 20 & 9.1 & 6.9 & 17 & 17 & 6.0 \\
\hline $\mathrm{HgO}$ & 0.1 & 0.1 & 0.1 & 0.1 & 0.1 & 0.1 & 0.0 & 0.0 & 0.1 & 0.1 & 1.1 & 1.0 & 0.7 & 0.5 & 1.2 \\
\hline $\mathrm{MnO}_{2}$ & 3.6 & 3.0 & 3.0 & 5.0 & 3.7 & 5.1 & 2.1 & 2.5 & 3.0 & 2.9 & 2.1 & 1.4 & 3.7 & 4.4 & 1.5 \\
\hline $\mathrm{NaCl}$ & 0.5 & 0.6 & 0.6 & 0.1 & 0.4 & 0.1 & 0.8 & 0.7 & 0.6 & 0.6 & 0.2 & 0.1 & 0.5 & 0.2 & 0.1 \\
\hline $\mathrm{NaNO}_{3}$ & 0.6 & 0.6 & 0.6 & 0.6 & 0.6 & 0.6 & 0.7 & 0.7 & 0.6 & 0.6 & 1.0 & 1.2 & 0.5 & 0.6 & 1.2 \\
\hline $\mathrm{NaOH}$ & 2.1 & 2.1 & 2.1 & 2.1 & 2.1 & 2.1 & 2.0 & 2.0 & 2.1 & 2.0 & 0.9 & 0.8 & 1.4 & 1.7 & 0.7 \\
\hline $\mathrm{Ni}(\mathrm{OH})_{2}$ & 2.0 & 1.8 & 1.8 & 2.4 & 2.0 & 2.4 & 1.6 & 1.7 & 1.8 & 1.8 & 0.4 & 0.6 & 0.7 & 1.6 & 0.4 \\
\hline $\mathrm{SiO}_{2}$ & 0.6 & 0.7 & 0.7 & 0.4 & 0.6 & 0.4 & 0.8 & 0.7 & 0.7 & 0.7 & 1.3 & 1.7 & 0.5 & 0.6 & 1.7 \\
\hline $\mathrm{ThO}_{2}$ & 0.0 & 0.0 & 0.0 & 0.0 & 0.0 & 0.0 & 0.0 & 0.0 & 0.0 & 0.0 & 0.4 & 0.4 & 0.1 & 0.1 & 0.5 \\
\hline $\begin{array}{c}\mathrm{UO}_{2}(\mathrm{OH}) \\
2\end{array}$ & 4.0 & 3.8 & 3.8 & 4.6 & 4.1 & 4.6 & 3.5 & 3.6 & 3.8 & 3.7 & 1.1 & 1.1 & 2.2 & 3.3 & 0.7 \\
\hline $\mathrm{H}_{2} \mathrm{O}$ & \multicolumn{15}{|c|}{60} \\
\hline Total & \multirow{2}{*}{\multicolumn{15}{|c|}{100}} \\
\hline $\begin{array}{l}\text { Total } \\
\text { Solids }\end{array}$ & & & & & & & & & & & & & & & \\
\hline $\begin{array}{l}\text { Slurry } \\
\text { sp.g. }\end{array}$ & \multicolumn{15}{|c|}{1.2} \\
\hline $\begin{array}{c}\text { Solids/L } \\
\text { Slurry }\end{array}$ & \multicolumn{15}{|c|}{$0.48(\mathrm{~kg} / \mathrm{L})$} \\
\hline
\end{tabular}

As can be seen above, the heel composition for Tanks 1-8 are very similar. The heel compositions in Tanks 9-15 show some variation. The heel compositions for Tanks 8 and 11 were picked to represent the base case Purex and HM dissolution models. Table 7-5 shows the different cases that will be considered in the material balance. 


\section{Table 7-5 Dissolution Material Balance Cases Considered \\ (Cases 1 - 4)}

\begin{tabular}{|c|c|c|}
\hline Case & $\begin{array}{c}\text { Heel from } \\
\text { Tank }\end{array}$ & $\begin{array}{c}\text { pH Adjustment } \\
\text { Method }\end{array}$ \\
\hline 1 & 8 & 50 wt $\% \mathrm{NaOH}$ \\
\hline 2 & 8 & supernate \\
\hline 3 & 11 & 50 wt $\% \mathrm{NaOH}$ \\
\hline 4 & 11 & supernate \\
\hline
\end{tabular}

Table 7-6 shows the assumed supernate composition used to adjust the $\mathrm{pH}$ of the spent/excess oxalic acid. The acid is considered to be adjusted to normal corrosion chemistry at $0.1 \mathrm{M} \mathrm{OH}^{-}$concentrations.

Table 7-6 Supernate Composition

\begin{tabular}{|c|c|}
\hline Component & Average (wt\%) \\
\hline $\mathrm{H}_{2} \mathrm{O}$ & $6.74 \mathrm{E}+2$ \\
\hline $\mathrm{NaNO}_{3}$ & $1.58 \mathrm{E}+1$ \\
\hline $\mathrm{NaOH}$ & $7.56 \mathrm{E}+0$ \\
\hline $\mathrm{NaNO}_{2}$ & $3.09 \mathrm{E}+0$ \\
\hline $\mathrm{NaAlO}_{2}$ & $2.15 \mathrm{E}+0$ \\
\hline $\mathrm{Na}_{2} \mathrm{SO}_{4}$ & $1.76 \mathrm{E}+0$ \\
\hline $\mathrm{Na}_{2} \mathrm{CO}_{3}$ & $1.41 \mathrm{E}+0$ \\
\hline Other salts & $6.7 \mathrm{E}-1$ \\
\hline $\mathrm{KOH}$ & $7.4 \mathrm{E}-2$ \\
\hline $\mathrm{NH} 4 \mathrm{NO}_{3}$ & $2.6 \mathrm{E}-3$ \\
\hline $\mathrm{CsOH}$ & $1.9 \mathrm{E}-3$ \\
\hline $\mathrm{Na} 2 \mathrm{U}_{2} \mathrm{O}$ & $6.2 \mathrm{E}-3$ \\
\hline $\mathrm{Sludge}$ & $4.8 \mathrm{E}-2$ \\
\hline $\mathrm{HgO}$ & $2.6 \mathrm{E} 03$ \\
\hline Total & 100 \\
\hline Density & $1.267(\mathrm{~kg} / \mathrm{L})$ \\
\hline
\end{tabular}

The simulation full material balance contained in Appendix 5 uses the volume of supernate needed to reach a pH of 12 . Tables A5-1 and A5-3 show the material balance of the heel dissolution for these tanks using $50 \mathrm{wt} \% \mathrm{NaOH}$ solution for $\mathrm{ph}$ 
adjustment. Table A5-2 and Table A5-4 show the same material balance using an average supernate for the adjustment.

Tables A5-1 through A5-4 show the added materials only, not necessarily existing tank farm material; thus, streams $9,10,12,14$, and 16 show only a material balance for added sodium oxalate. Stream 12 shows zero sodium oxalate transferred, because $100 \%$ remains in the heel.

\subsection{Sludge Washing}

Assuming that the slurry from heel removal is added to the sludge washing tank at the beginning of the sludge batch, the decanted liquid from sludge transfers and washing will remove some oxalate from the sludge batch. The sludge washing targeted a total sodium concentration of less than $1.0 \mathrm{M}$. Assuming the same target is acceptable, the effect on sludge washing is shown in Table 7-7. Nearly all of the added sodium oxalate from one dissolved heel will be washed out of the sludge batch.

With no changes to the washed sludge batches, $60,500 \mathrm{~kg}$ of sodium oxalate could be added to the sludge batch before residual solid sodium oxalate would remain with the sludge slurry after final planned wash. The total sodium concentration would be approximately $1 \mathrm{M}$. At this hypothesized maximum capacity, the total oxalate in the sludge batch would be about $23,000 \mathrm{~kg}$. This translates to $4.7 \mathrm{wt} \%$ of total solids.

Among the cases examined, two to three dissolved heels could be sent to sludge washing before either sodium oxalate would accumulate in the solids or wash water batches would increase in size or number to achieve the same washing goal. In contrast, if the dissolved heel is added to the washed sludge batch, all the sodium oxalate would become part of the final batch. The sodium oxalate amounts to about 67 to $75 \mathrm{wt} \%$ of the total solids added to the sludge batch. The remainder consists primarily of other metal oxalates formed from dissolution of the heel. The final sodium oxalate from one heel dissolution from case 4 (Tank 11 with $\mathrm{pH}$ adjusted 
using supernate) would equate to $7.3 \mathrm{wt} \%$. The sodium concentration in solution would still be about $1 \mathrm{M}$, but the total sodium in the slurry would increase substantially, by about $13,200 \mathrm{~kg}$. Thermodynamically, the formation of iron, manganese, and aluminum oxalates are favored; however, the reaction occurs in solution.

The concentrations of metals in solution are very small, and the oxalate is sparingly soluble, so that the driving potential for the reaction is low. In other words, the rate of reaction will be very slow. The product of the reaction is soluble sodium salts, primarily sodium hydroxide, which would readily wash out of the sludge slurry. If these reactions occur to any appreciable extent before washing the sludge batch, then the amount of metal oxalates will increase, and the amount of sodium oxalate will decrease. The total sodium will decrease because sodium that is more soluble will wash out. If these reactions occur in the washed sludge batch, the free hydroxide will tend to increase, and the sodium concentration will remain unchanged. 
Table 7-7 Sodium Oxalate Balance for Sludge Washing

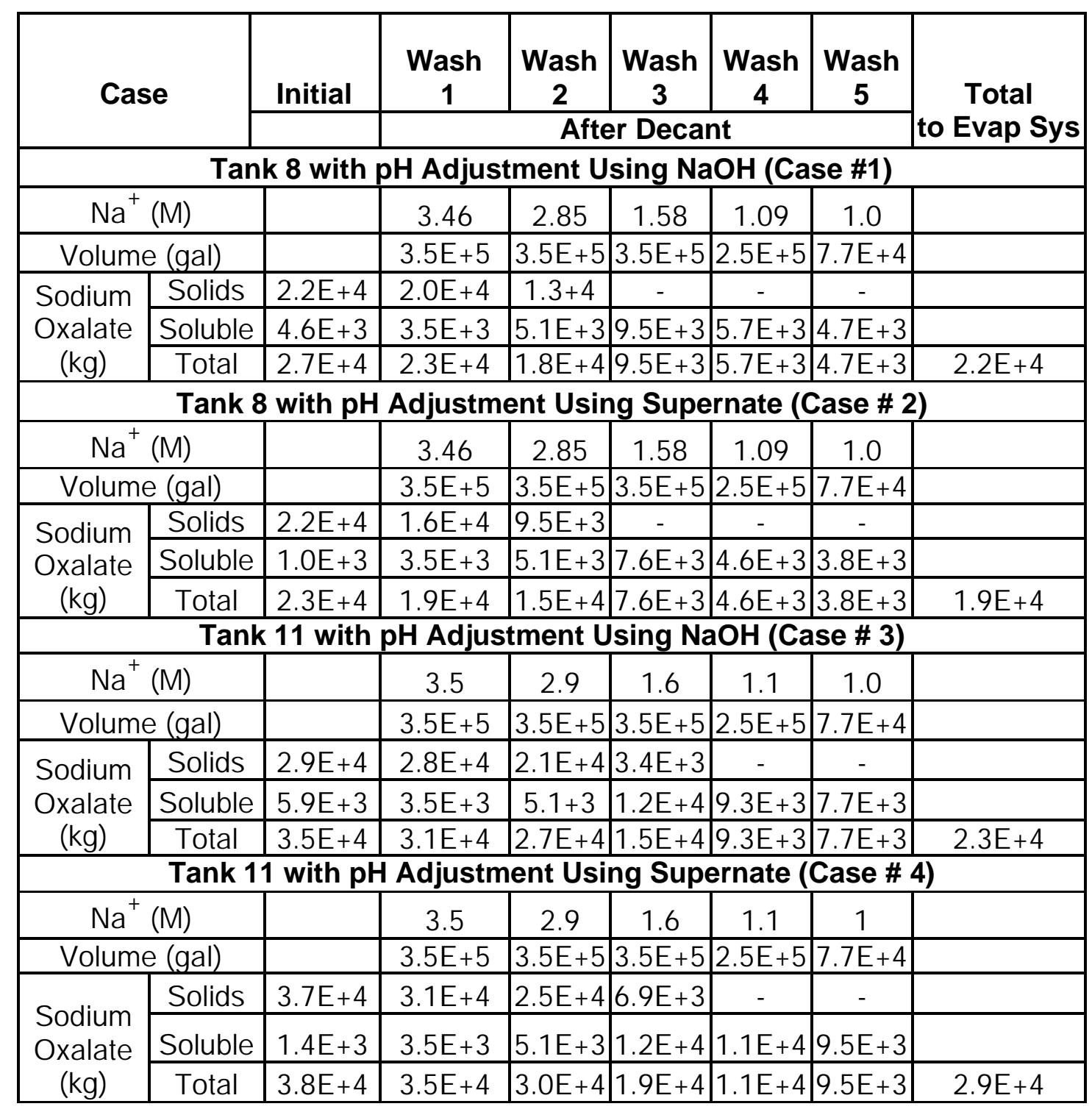

\subsection{Tank Farm Evaporation}

The material balance is calculated using expected starting conditions based on assumed current process parameters. Table 7-8 shows the initial feed tank composition. Table 7-9 shows the results for transferring one liquid decant from heel dissolution to the evaporator feed tank for each case.

The evaporator model results indicate that only a relatively small amount of sodium oxalate will be fed to the evaporator and subsequently to the drop tank. About 1,000 
to $1,200 \mathrm{~kg}$ move from the feed tank to the drop tank during the simulated 3,000 hours of operation. Tables 7-8 and 7-9 show example evaporator model results for case 2 (i.e., Tank 8 with pH adjustment using supernate). The amount of sodium oxalate in the evaporator feed decreases to the point that the remaining sodium oxalate in the feed tank practically does not change. The concentration in the aqueous phase decreases due to the increase in total sodium concentration or ionic strength. Additionally, more sodium oxalate will transfer to the drop tank with each large transfer of fresh, relatively dilute waste into the feed tank. If no additional sodium oxalate is added to the tank, the remaining oxalate will eventually be deposited into the drop tank. The bottom of the feed tank, however, contains a sludge layer. When the precipitated sodium oxalate settles into the sludge layer, the sludge will tend to inhibit further dissolution by coating the solids, thus, slowing the effective transfer from the feed tank to the drop tank.

If the stream 8 (i.e., pH adjusted supernate) is added to the evaporator drop tank, practically all the sodium oxalate will remain with the saltcake. The high sodium concentration perpetually present in the drop tank will cause nearly all the oxalate to precipitate. The addition of the $\mathrm{pH}$ adjusted supernate to the evaporator drop tank and evaporator feed tank are contrasted in Figures 7-3 and 7-4. 
Table 7-8 Evaporator Feed Tank Initial Composition

\begin{tabular}{|c|c|}
\hline Chemical Compound & Feed Tank (M) \\
\hline $\mathrm{NaNO}_{3}$ & $1.82 \mathrm{E}+0$ \\
\hline $\mathrm{Na}_{2} \mathrm{CO}_{3} \cdot \mathrm{H}_{2} \mathrm{O}$ & $8.76 \mathrm{E}-2$ \\
\hline $\mathrm{NaNO}_{2}$ & $1.69 \mathrm{E}+0$ \\
\hline $\mathrm{NaAlO}_{2} \cdot 2 \mathrm{H}_{2} \mathrm{O}$ & $1.14 \mathrm{E}-1$ \\
\hline $\mathrm{Na}_{2} \mathrm{C}_{2} \mathrm{O}_{4}$ & $6.19 \mathrm{E}-2$ \\
\hline $\mathrm{Na}_{2} \mathrm{SO}_{4}$ & $2.39 \mathrm{E}-2$ \\
\hline $\mathrm{NaCl}$ & $3.48 \mathrm{E}-2$ \\
\hline $\mathrm{NaF}$ & $5.79 \mathrm{E}-2$ \\
\hline $\mathrm{NaOH}$ & $4.71 \mathrm{E}+0$ \\
\hline $\mathrm{Na}_{3} \mathrm{PO}_{4}$ & $6.51 \mathrm{E}+3$ \\
\hline $\mathrm{Na}_{2} \mathrm{SiO}_{3}$ & $7.84 \mathrm{E}-2$ \\
\hline
\end{tabular}

Stream 15 (i.e., the decant/wash water), will simply add additional sodium oxalate directly to the solids layer of the evaporator feed or drop tank. If added to the feed tank, large quantities of sodium oxalate will accumulate in the sludge layer. The sodium oxalate will be moved back to the sludge wash tank when the appropriate sludge batch calls for the feed tank sludge. A large portion will return to the feed tank via the sludge washing process.

As noted earlier, if more than two or three heel dissolutions are accumulated in the evaporator feed tank, (i.e., about $60,000 \mathrm{~kg}$ of sodium oxalate) then all the sodium oxalate above this threshold will become part of the washed sludge slurry. A quantity less than $60,000 \mathrm{~kg}$ will tend to remain in the feed tank until eventual heel removal. 
Table 7-9 Sodium Oxalate Balance for the Evaporator

\begin{tabular}{|c|c|c|c|c|c|c|c|c|}
\hline \multirow[t]{2}{*}{ Tank } & \multicolumn{2}{|c|}{$\begin{array}{l}\text { Case } 1 \text { - } \\
\text { Tank } 8 \\
\mathrm{NaOH} \\
\end{array}$} & \multicolumn{2}{|c|}{$\begin{array}{c}\text { Case } 2 \text { - } \\
\text { Tank } 8 \\
\text { Supernate } \\
\end{array}$} & \multicolumn{2}{|c|}{$\begin{array}{c}\text { Case 3- } \\
\text { Tank } 11 \\
\mathrm{NaOH} \\
\end{array}$} & \multicolumn{2}{|c|}{$\begin{array}{c}\text { Case } 4 \text { - Tank } \\
11 \\
\text { Supernate } \\
\end{array}$} \\
\hline & $\begin{array}{c}\mathrm{Na}_{2} \mathrm{C}_{2} \mathrm{O}_{4} \\
(\mathrm{~kg})\end{array}$ & $\begin{array}{c}\% \\
\text { Add }\end{array}$ & $\begin{array}{c}\mathrm{Na}_{2} \mathrm{C}_{2} \mathrm{O}_{4} \\
(\mathrm{~kg})\end{array}$ & $\begin{array}{c}\% \\
\text { Add }\end{array}$ & $\begin{array}{c}\mathrm{Na}_{2} \mathrm{C}_{2} \mathrm{O}_{4} \\
(\mathrm{~kg})\end{array}$ & $\begin{array}{c}\% \\
\text { Add }\end{array}$ & $\begin{array}{c}\mathrm{Na}_{2} \mathrm{C}_{2} \mathrm{O}_{4} \\
(\mathrm{~kg})\end{array}$ & $\begin{array}{c}\% \\
\text { Add }\end{array}$ \\
\hline & 2940 & - & 2890 & - & 2917 & - & 2670 & - \\
\hline & 1100 & - & 1140 & - & 1115 & - & 1370 & - \\
\hline $\begin{array}{l}\text { Added to } \\
\text { Feed Tank }\end{array}$ & 4110 & - & 1370 & - & 5893 & - & 2000 & - \\
\hline $\begin{array}{l}\text { Remains } \\
\text { in Feed } \\
\text { Tank }\end{array}$ & 5940 & 73 & 3100 & 15 & 7666 & 81 & 3700 & 52 \\
\hline $\begin{array}{l}\text { Remains } \\
\text { in Drop } \\
\text { Tank }\end{array}$ & 2250 & 28 & 2390 & 91 & 2343 & 21 & 2360 & 50 \\
\hline $\begin{array}{l}\text { Transfer to } \\
\text { Drop Tank }\end{array}$ & 1150 & - & 1250 & - & 1230 & - & 990 & \\
\hline
\end{tabular}

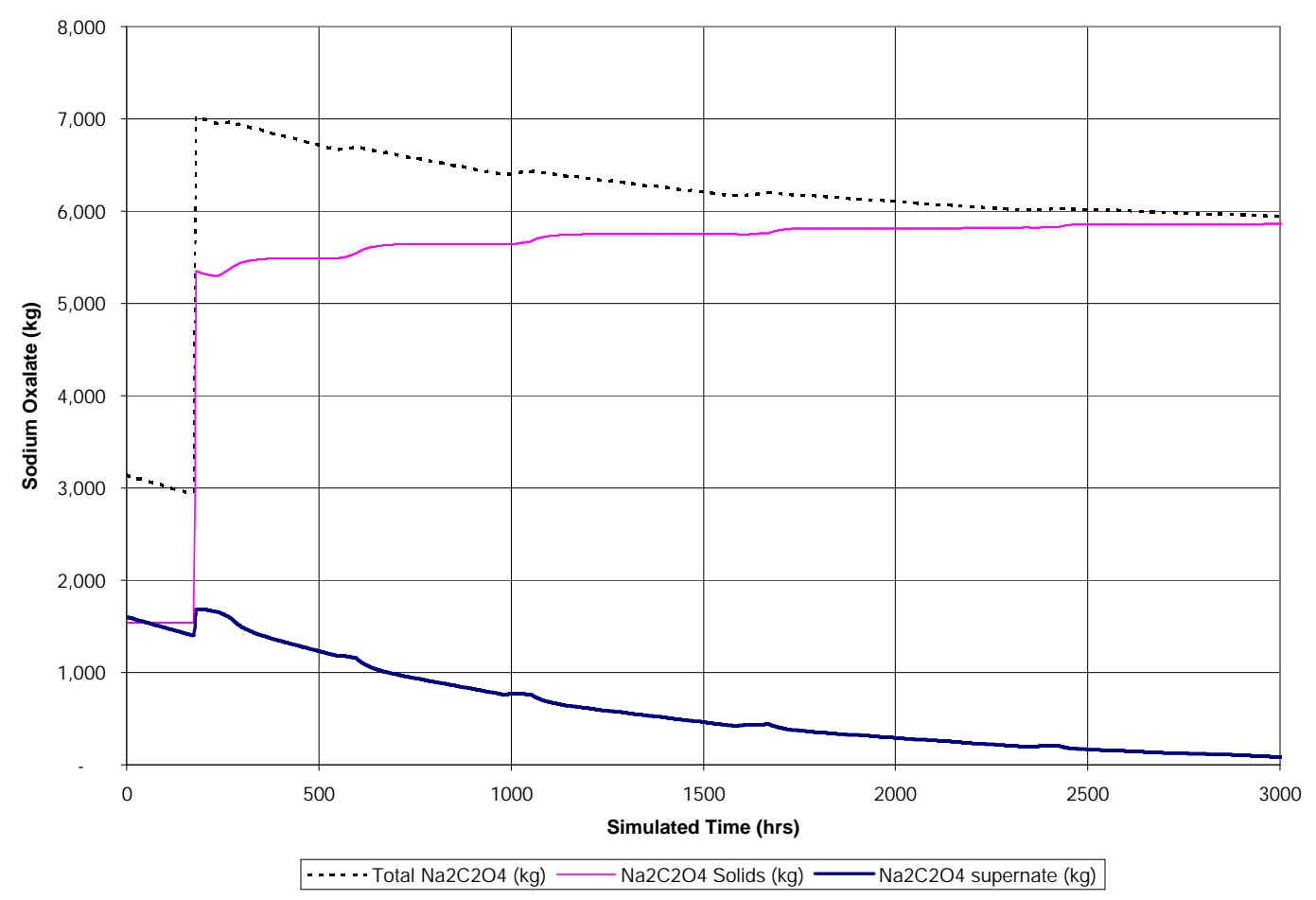

Figure 7-3 Oxalate from pH Adjusted Liquid Added to Feed Tank (Stream 8) for Case 2 (Tank 8 with pH Adjusting Supernate) 


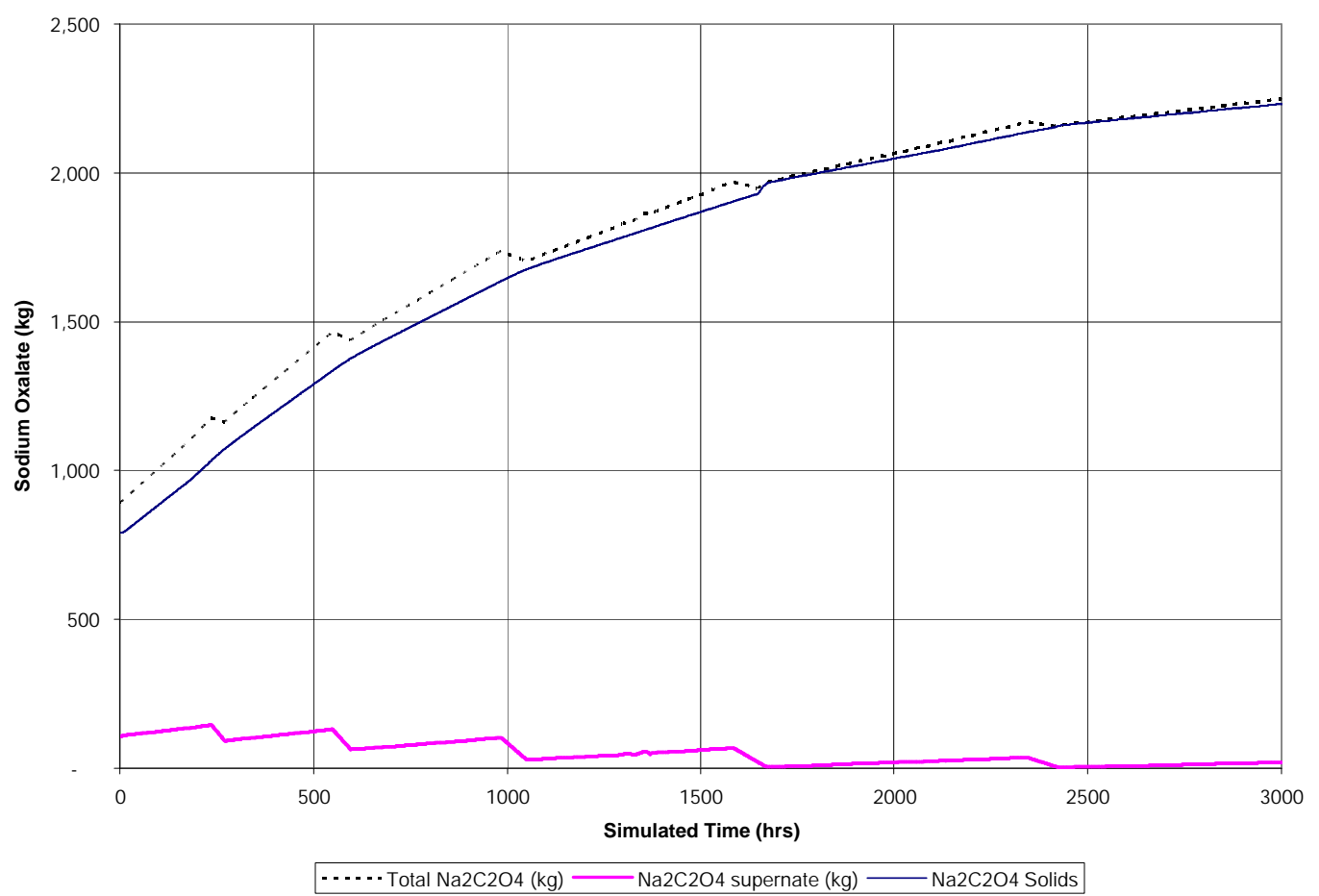

Figure 7-4 Oxalate from pH Adjusted Liquid Added to Drop Tank (Stream 8) for Case 2 (Tank 8 with pH Adjusting Supernate)

\subsection{Salt Dissolution}

Salt dissolution is an ongoing effort within the tank farms. About 2.2 gallons of water is added to each gallon of saltcake to produce about 3.2 gallons of SWPF feed solution at a total sodium concentration of 6.4 M [Pike, 2002]. In a salt tank with 1 million gallons of saltcake, about 3.2 million gallons of dissolved salt solution will be created to feed the salt process. At $6.4 \mathrm{M}$ sodium, sodium oxalate has a total solubility as shown in Equation 7-1 [Pike, 20002].

$$
\operatorname{Max}\left[\mathrm{Na}_{2} \mathrm{C}_{2} \mathrm{O}_{4}\right]=\mathrm{T} \times\left(1.59 \mathrm{E}-3 \times \mathrm{I}^{-1.444}\right)+\left(7.23 \mathrm{E}-2 \times \mathrm{I}^{-1.424}\right)
$$

Where:

$\mathrm{T}=$ temperature in Celsius, and

I = total sodium concentration in molarity. 
Assuming $30^{\circ} \mathrm{C}$ and $6.4 \mathrm{M}$ total sodium concentration, the saturation level of sodium oxalate is about $8.4 \mathrm{E}-3 \mathrm{M}$. At this saturation concentration, the total oxalate dissolved would be as much as $13,600 \mathrm{~kg}$ of sodium oxalate. If the saltcake contains more sodium oxalate, the additional oxalate would make up part of the relatively insoluble or low solubility heel.

Average saltcake solids contain about 0.45 wt $\%$ sodium oxalate. In 1,000,000 gallons of saltcake with an average solids specific gravity of 2.3 and typical solid void fraction of 0.40 , the saltcake already contains about $23,500 \mathrm{~kg}$ of sodium oxalate; therefore, on average, all added sodium oxalate to the saltcake will become part of the low solubility salt heel. In certain tanks with existing saltcake at low oxalate content, sodium oxalate could be added to the saltcake with no impact to the residual. Refer to Table 7-10.

Table 7-10 Average Saltcake Composition

\begin{tabular}{|c|c|}
\hline Chemical Compound & Saltcake (wt\%) \\
\hline $\mathrm{NaNO}_{3}$ & $8.6 \mathrm{E}+1$ \\
\hline $\mathrm{Na}_{2} \mathrm{CO}_{3} \cdot \mathrm{H}_{2} \mathrm{O}$ & $5.7 \mathrm{E}+0$ \\
\hline $\mathrm{NaNO}_{2}$ & $8.2 \mathrm{E}-1$ \\
\hline $\mathrm{NaAlO}_{2} \cdot 2 \mathrm{H}_{2} \mathrm{O}$ & $2.2 \mathrm{E}+0$ \\
\hline $\mathrm{Na}_{2} \mathrm{C}_{2} \mathrm{O}_{4}$ & $4.5 \mathrm{E}-1$ \\
\hline $\mathrm{Na}_{2} \mathrm{SO}_{4}$ & $2.9 \mathrm{E}+0$ \\
\hline $\mathrm{NaCl}$ & $6.8 \mathrm{E}-3$ \\
\hline $\mathrm{NaF}$ & $1.7 \mathrm{E}-1$ \\
\hline $\mathrm{NaOH}$ & $7.3 \mathrm{E}-1$ \\
\hline $\mathrm{Na}_{3} \mathrm{PO}_{4}$ & $5.9 \mathrm{E}-1$ \\
\hline
\end{tabular}

\subsection{Salt Processing and Saltstone}

All the dissolved sodium oxalate will pass through salt processing with the other soluble sodium salts being transferred to the Saltstone facility. About $13,600 \mathrm{~kg}$ of sodium oxalate is expected to be sent to salt processing per $1,000,000$ gallons of saltcake processed. There are no existing plans to remove solid heels after bulk salt removal. The planned salt processing will pass the sodium oxalate in its entirety to 
the saltstone facility where it will be incorporated into a final solid waste form. The concentrations of sodium oxalate are assumed to be well within the Waste Acceptance Criteria (WAC) for the saltstone facility.

\subsection{Vitrification}

SRNL studied the effect of substantial sodium oxalate in sludge batch 3 on the Defense Waste Processing Facility (DWPF) vitrification process. The tests were completed for sodium oxalate at 2.96, 5.74, 8.37 and 13.21 wt $\%$ of total solids [Herman, 2003; Peeler, 2003]. These studies show the DWPF Sludge Receipt and Adjustment Tank (SRAT) is affected as follows.

- Negligible amounts of iron and gadolinium become soluble with sodium oxalate at $5.74 \mathrm{wt} \%$ of total solids.

- Iron becomes ten times more soluble when sodium oxalate increases to $8.37 \mathrm{wt} \%$ or $13.21 \mathrm{wt} \%$ of total solids.

- Gadolinium becomes completely soluble at $13.21 \mathrm{wt} \%$ sodium oxalate

- Sodium oxalate mitigates the release of hydrogen.

- More acid is required for $5.74 \mathrm{wt} \%$ or higher sodium oxalate to complete nitrite destruction, which implies slightly longer cycle times for the SRAT.

If the sodium oxalate content is kept below $6 \mathrm{wt} \%$, solubility of iron and gadolinium is kept low enough to be negligibly affected. This amounts to about $150,000 \mathrm{~kg}$ of sodium oxalate being acceptable in sludge batch 3 . Glass processing studies to determine acceptability of sludge batch 3 , with elevated sodium oxalate concentrations, show mixed results. The process is highly influenced by the choice of the glass frit used to vitrify the waste.

Peeler [2003] demonstrated a $5 \%$ increase in the number of canisters with moderate sodium oxalate content of about $3 \mathrm{wt} \%$ verses no sodium oxalate. The slightly higher waste loading offsets the additional sodium in the sludge slurry. At nearly 6 wt\% sodium oxalate, the frit formulation must be changed to remain acceptable with no practical change in canisters produced due to increased waste loading. An 8.37 
wt $\%$ sodium oxalate represents $50 \%$ more oxalate than 5.74 wt $\%$ and results in $28 \%$ increase in canisters [Peeler, 2003].

Using sludge batch 4 for an example, a 28\% increase would change the net canisters predicted from 505 canisters to 646 . This estimate is only a guide to the magnitude of the change. A specific frit optimization study and batch qualification analysis would identify effects that are more precise. In order to process higher sodium oxalate concentrations, new frit formulations would need to be implemented. Refer to Table 7-11.

Table 7-11 Effect of Sodium Oxalate in Sludge Batch 3 at DWPF

\begin{tabular}{|c|c|c|c|c|c|}
\hline $\begin{array}{l}\text { Sodium } \\
\text { Oxalate } \\
\text { (wt\%) }\end{array}$ & Frit & Limitation & \begin{tabular}{|c|}
$\%$ Waste \\
Oxide Loading
\end{tabular} & $\begin{array}{l}\text { Canisters } \\
\text { Produced }\end{array}$ & Notes \\
\hline 0 & 320 & Liquidus & 36.5 & 560 & \\
\hline 0 & 202 & $\begin{array}{c}\text { High } \\
\text { Viscosity }\end{array}$ & & & No acceptable blend \\
\hline 2.96 & 320 & $\begin{array}{c}\text { Low } \\
\text { Viscosity }\end{array}$ & 38.1 & 589 & \\
\hline 2.96 & 202 & $\begin{array}{c}\text { High } \\
\text { Viscosity }\end{array}$ & 31.5 & 712 & $\begin{array}{c}\text { F rit } 320 \text { is better when } \\
\text { most of the oxalate has } \\
\text { been removed. }\end{array}$ \\
\hline 5.74 & 320 & Durability & & & No acceptable blend \\
\hline 5.74 & 202 & Liquidus & 44.2 & 553 & \\
\hline 8.37 & 202 & Durability & 37.0 & 714 & \\
\hline 10.86 & 202 & Durability & & & No acceptable blend \\
\hline
\end{tabular}

- All residual transfers to the drop tank, including any sludge washing decants, will result in a large salt heel after bulk salt removal that consists mostly of sodium oxalate. A process needs to be developed to treat/remove the heel.

- Planned salt dissolution will send no more than $14,000 \mathrm{~kg}$ of dissolved sodium oxalate per $1,000,000$ gallons of saltcake to the salt waste processing and eventually to the Saltstone Facility. 


\subsection{Effect on Waste Processing}

Sludge heel cleaning with oxalic acid essentially results in two streams that need to be dispositioned. The first is the $\mathrm{pH}$ adjusted supernate (i.e., stream 8), and the second is the sludge with the precipitated sodium oxalate solids slurry (i.e., stream 13).

\subsubsection{Adjusted Supernate}

The $\mathrm{pH}$-adjusted supernate will eventually be sent to the evaporator system. The liquid may be sent to either the evaporator feed or drop tank. If this liquid is sent to the evaporator feed tank, most of the sodium oxalate will precipitate and remain in the feed tank, as shown in Section 7.6. Effectively, the sodium oxalate will build up in the sludge layer of the feed tank. This could become unmanageable for sludge blending.

If sent to the drop tank, practically all the sodium oxalate remains in the drop tank. All the added oxalate becomes part of the saltcake heel after bulk salt removal and will need to be processed with the solid salt/sludge. Potentially, all the low solubility salts and sodium oxalate remaining could be dissolved and processed through the SWPF as additional saltstone. This is discussed in Section 7.7. The additional amount of sodium oxalate in the feed stream to the Saltstone Facility will have only a small impact on the volume of Saltstone produced.

About $6,000 \mathrm{~kg}$ of sodium oxalate per 5000 gallon sludge heel dissolved could be in this stream and would generate about 50,000 gallons of additional dilute Saltstone feed.

Given the potential operational problems with sending this stream to the evaporator feed tank, the preferred option is to send this stream to any evaporator drop tank, including salt tanks that are not currently active. 


\subsubsection{Solids Slurry}

The solids slurry will be sent to DWPF for incorporation into a glass waste form. This stream may be sent to either the sludge-washing tank or the DWPF feed tank. If the solids slurry is sent the sludge-washing tank, solids slurry from two to three sludge heels could be added, and practically all the sodium oxalate would be washed out of the batch with no effect on the sludge batch as discussed in Section 7.5. All the sodium oxalate would end up in the evaporator system with significant impact to the salt heel removal and final disposal at the Saltstone facility as discussed in Section 7.8 .

The second option is to wash the sludge to a low enough sodium level first and then add the solids slurry to the batch. This will result in all of the insoluble sludge solids and metal oxalates being sent to DWPF. Given the experience with sludge batch 3, considerable sodium oxalate could be added to a batch with negligible difference to the process or canisters produced, as long as the addition is included in batch planning and qualification testing. Testing shows that processing in the SRAT can readily tolerate $26 \mathrm{wt} \%$ sodium oxalate of total solids; glass performance tests could limit the tolerance to $10 \mathrm{wt} \%$, more or less depending on the amount of sludge batch washing [Peeler, 2003]. Sludge batch qualification testing with more alternate frit formulations might loosen this constraint.

Given that DWPF can readily accommodate only a small increase in sodium oxalate concentration (about $10 \mathrm{wt} \%$ ), the preferred option is to add the solids slurry to the sludge feed tank and feed it to DWPF at a small, steady rate. This will prevent having to deal with sludge with a significantly larger sodium oxalate concentration at some future date. 


\subsubsection{Recommended Process Flowsheet}

Figure 7-5 shows the process flowsheet after including the preferred process choices discussed above. For a 5,000-gallon F-Area sludge heel, 65,000 gallons of 8 wt\% acid should be used. For a 5000-gallon H-Area sludge heel, 85,000 gallons of 8 wt\% should be used.

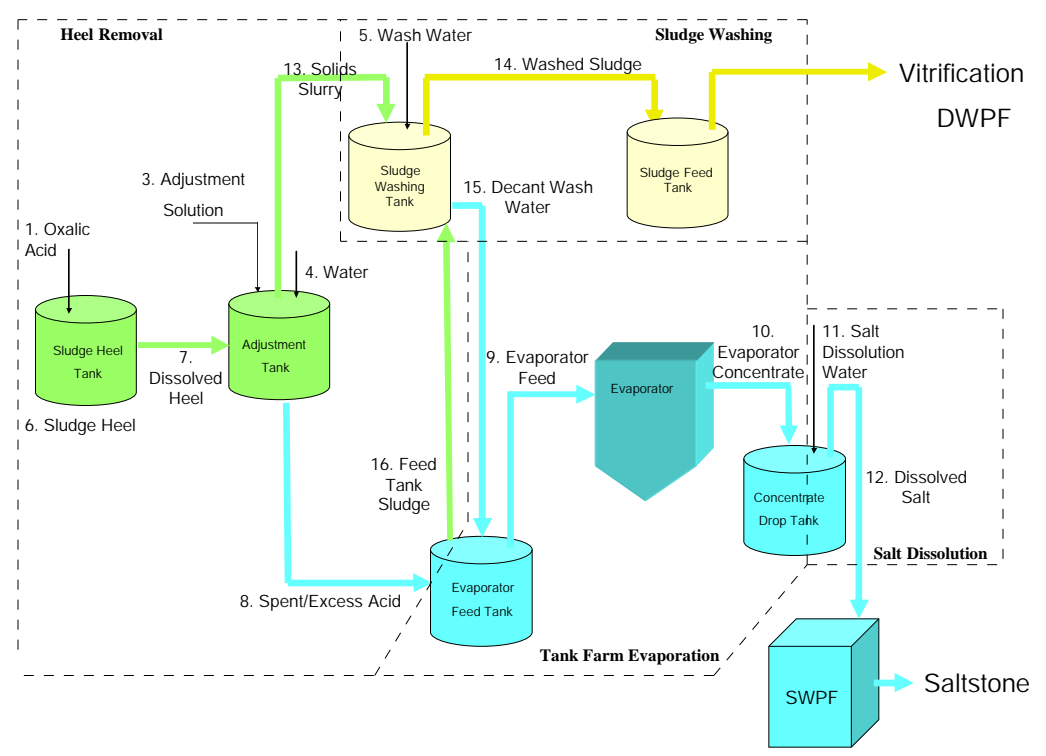

Figure 7-5 Recommended Heel Removal Flow Diagram

Using Figure 7-5, the recommended flow path can be summarized as follows:

The (6)sludge heel is treated with (1) acid. (6)+(1) is transferred as (7) to a pH adjustment tank that has been pre-treated with ph adjusting supernate (3). Slurry Solids (13) go with washed sludge batch (14) to DWPF. The resulting pH adjusted supernate (8) should be transferred to the evaporator drop tank. The oxalate will form a small amount of solids and will build up in the drop tank, until sometime in the future the salt heel is removed (12) via SWPF. 


\section{11 Conclusion on Processability}

Sludge heel cleaning with oxalic acid essentially results in two streams that need to be dispositioned. The first is the $\mathrm{pH}$ adjusted supernate liquid stream, and the second is the sludge with the precipitated metal oxalate solids slurry stream. The preferred flowsheet calls for the supernate to be added to an evaporator drop tank and subsequent disposal with the saltcake heel. The solids slurry would be added to a washed sludge batch and subsequently disposed with a sludge batch to the DWPF. The preferred flowsheets, case 2 (Purex dissolution with $\mathrm{pH}$ adjustment using supernate) and case 4, (HM dissolution with $\mathrm{pH}$ adjustment using supernate) include recommended amounts of oxalic acid based on sludge stream composition.

Based on the preferred flowsheet and data from sludge batch 3 qualification tests, the following conclusions are made concerning the effect on DWPF:

- Sodium oxalate from the solids slurry can be added to a sludge batch without affecting the number of canisters produced.

- The feed to the SRAT can tolerate up to $26 \mathrm{wt} \%$ sodium oxalate in total solids.

- Increasing metal oxalate in the feed to the SRAT increases formic and nitric acid consumption, thus, increasing SRAT cycle time.

- Glass quality limits the total amount of sodium in a batch without increasing the number of canisters produced.

- Using past experience with sludge batch 3 to calculate a general planning guide, the maximum sodium content in a sludge batch without further studies is $1.4 \mathrm{M}$ sodium.

- If sludge processing washes the soluble sodium content to about $1 \mathrm{M}$, the sludge batch can contain about $10 \mathrm{wt} \%$ of total solids as sodium oxalate before increasing the number of canisters produced or changing sludge processing. 
- If all of the metal oxalate becomes part of a sludge batch, about 26,000 to $38,000 \mathrm{~kg}$ sodium oxalate is added to the sludge batch per 5,000 gallon sludge tank heel processed.

- $10 \mathrm{wt} \%$ sodium oxalate in total solids amounts to disposal of 1 to 6 sludge heels depending on waste type of sludge heel cleaned and specific sludge batch.

- $\quad$ Solid slurries from tank heel cleaning should be bled into the DWPF feed stream at a relatively low rate.

- $\quad$ Solid slurry additions from heel cleaning should be included in future sludge batch planning.

The following conclusions are made concerning the effect on the tank farm waste storage and evaporator systems.

- $\quad$ Planned salt dissolution will send about $14,000 \mathrm{~kg}$ of dissolved sodium oxalate per 1,000,000 gallons of saltcake, all of which currently exists in the saltcake, to the salt waste processing facilities and eventually to the Saltstone Facility.

- All sodium oxalate added to an evaporator drop tank will remain in the drop tank.

- Planned bulk saltcake dissolution will remove none of the sodium oxalate added to an evaporator drop tank, thus, becoming part of the salt heel. 


\section{SENSITIVITY ANALYSIS}

\subsection{Introduction to Sensitivity}

The purpose of the sensitivity analysis is to demonstrate the sensitivity of the model simulations to uncertainty and possible variations of input. Forecasts, based on an insensitive model, will show similar outcomes regardless of variations in the input, and will have a predictable outcome. Alternately, sensitive models will have a less predictable outcome.

A recommended flowpath was determined in Chapter 7. For both Purex sludge heel dissolution and HM sludge heel dissolution, to maximize the available HLW tank space, readily available supernate will be used to adjust the $\mathrm{pH}$ of the spent/excess oxalic acid. To help ensure sodium oxalate solids do not build up within the system, the precipitated solids will be added to a washed sludge batch, while the $\mathrm{pH}$-adjusted supernate will be added to the evaporator drop tank.

The defined material balance for the Tank 8 Purex sludge heel dissolution is mathematically presented in Table A5-2, while the defined processing plan for the Tank 11 HM case is presented in Table A5-4.

\subsection{SENSITIVITY TO VARIATIONS}

As previously stated in Chapter 7, Tanks 1-9 have the same relative distributions, whereas the distributions in Tanks 10-15 vary. Using the OLI Stream Analyzer ${ }^{\odot}$ and OLI ESP ${ }^{\odot}$ survey functions, a sensitivity analyses was performed for single constituents using a minimum of ten intervals of varying applicable increments. Table 8-1 shows modeled Purex Sludge dissolution sensitivity to individual variations in sludge constituents. 
Table 8-1 Sensitivity of Dissolution to Purex Sludge Variations

\begin{tabular}{|c|c|c|c|}
\hline Constituent & $\begin{array}{c}\text { Baseline Mass } \\
\text { (kg/ 5K gallon } \\
\text { Heel) }\end{array}$ & $\begin{array}{c}\mathbf{\pm} \cdot \text { Baseline Mass (kg) } \\
\pm \mathbf{\pm} \text { Remaining Total Solids } \\
\text { Mass (kg) }\end{array}$ & $\begin{array}{c}\text { Approx. } \\
\text { Linear Range } \\
(\mathbf{k g})\end{array}$ \\
\hline $\mathrm{Al}(\mathrm{OH})_{3}$ & 1,430 & $100 / 6.7$ & $1,000-2,000$ \\
\hline $\mathrm{Fe}(\mathrm{OH})_{3}$ & 5,444 & $100 / 5.7$ & $1,000-8,000$ \\
\hline $\mathrm{Mn}(\mathrm{OH})_{2}$ & 558 & $100 / 181$ & $200-700$ \\
\hline $\mathrm{Ni}(\mathrm{OH})_{2}$ & 425 & $100 / 193$ & $100-600$ \\
\hline $\mathrm{UO}_{2}(\mathrm{OH})_{2}$ & 929.5 & $100 / 1.5$ & $700-1,200$ \\
\hline $\mathrm{SiO}_{2}$ & 211.6 & $100 / 94$ & $150-250$ \\
\hline $\mathrm{CaCO}_{3}$ & 579 & $100 / 294$ & $200-700$ \\
\hline $\mathrm{Ce}_{2} \mathrm{O}_{3}$ & 22.7 & $100 / 57$ & $15-30$ \\
\hline
\end{tabular}

Since the impact is expressed as a linear relationship, the observed forecast determined approximate linear graphic range. Outside this range for the modeling performed, the software results no longer showed a linear sensitivity/relationship. Because of limited testing (measured) results; however, no attempt could be made to determine if it was actual or software related.

Based on Table 8-1, changes in carbonate mass have the biggest impact on Purex sludge dissolution, while dissolution is not as sensitive to small mass changes in $\mathrm{Al}(\mathrm{OH})_{3}$ and $\mathrm{Fe}(\mathrm{OH})_{3}$. Table 8-2 shows the variation in $\mathrm{HM}$ sludge dissolution based on changes to individual constituent mass. 
Table 8-2 Sensitivity of Dissolution to HM Sludge Slurry Variations

\begin{tabular}{|c|c|c|c|}
\hline Constant & $\begin{array}{c}\text { Baseline Mass } \\
\text { (kg/ } 5 \mathrm{~K} \text { gallon } \\
\text { Heel) }\end{array}$ & $\begin{array}{c}\underline{ \pm} \cdot \text { Constituent Mass }(\mathrm{kg}) \\
\underline{\underline{ \pm}} \cdot \begin{array}{c}\text { Remaining Total Solids } \\
\text { Mass }(\mathrm{kg})\end{array}\end{array}$ & $\begin{array}{c}\text { Approx. } \\
\text { Linear Range } \\
(\mathbf{k g})\end{array}$ \\
\hline $\mathrm{Al}(\mathrm{OH})_{3}$ & 5,521 & $100 / 0.8$ & $3,000-6,000$ \\
\hline $\mathrm{Fe}(\mathrm{OH})_{3}$ & 2,385 & $100 / 0.8$ & $1,000-3,000$ \\
\hline $\mathrm{Mn}(\mathrm{OH})_{2}$ & 549 & $100 / 184$ & $200-700$ \\
\hline $\mathrm{Ni}(\mathrm{OH})_{2}$ & 104.2 & $100 / 192$ & $75-150$ \\
\hline $\mathrm{UO}_{2}(\mathrm{OH})_{2}$ & 287.3 & $100 / 4$ & $200-350$ \\
\hline $\mathrm{SiO}_{2}$ & 332.5 & $100 / 91$ & $300-400$ \\
\hline $\mathrm{CaCO}_{3}$ & 579 & $100 / 464$ & $500-600$ \\
\hline $\mathrm{Ce}_{2} \mathrm{O}_{3}$ & 115.9 & $100 / 50$ & $75-150$ \\
\hline $\mathrm{NaNO}_{3}$ & 186 & $100 / 0$ & $100-250$ \\
\hline $\mathrm{NaOH}$ & 225.9 & $100 / 12$ & $125-225$ \\
\hline $\mathrm{ThO}_{2}$ & 104.2 & $100 / 0.1$ & NA \\
\hline $\mathrm{HgO}$ & 287.3 & $100 / 0$ & $200-300$ \\
\hline
\end{tabular}

Based on Table 8-2, changes in carbonate mass also have the biggest impact on $\mathrm{HM}$ sludge dissolution, while $\mathrm{Al}(\mathrm{OH})_{3}$ and $\mathrm{Fe}(\mathrm{OH})_{3}$ appear to be among the least sensitive. Using variations in quantities of oxalic acid and the 5,000-gallon Purex sludge heel dissolution, the oxalic acid is varied and the mass of the treatment tank solids is shown in Table 8-3.

Table 8-3 Solids in Purex Sludge Treatment Tank from Excess Oxalic Acid

\begin{tabular}{|c|c|}
\hline Oxalic Acid (kg) & Precipitated Treatment Tank Solids (kg) \\
\hline 5,000 & $7.81 \mathrm{E}+3$ \\
\hline 10,000 & $3.74 \mathrm{E}+3$ \\
\hline 15,000 & $2.65 \mathrm{E}+3$ \\
\hline 20,000 & $2.75 \mathrm{E}+3$ \\
\hline 25,000 & $2.79 \mathrm{E}+3$ \\
\hline 30,000 & $2.80 \mathrm{E}+3$ \\
\hline 35,000 & $2.80 \mathrm{E}+3$ \\
\hline 40,000 & $5.41 \mathrm{E}+3$ \\
\hline 45,000 & $1.28 \mathrm{E}+4$ \\
\hline 50,000 & $2.01 \mathrm{E}+4$ \\
\hline 55,000 & $2.74 \mathrm{E}+4$ \\
\hline 60,000 & $3.48 \mathrm{E}+4$ \\
\hline 65,000 & $4.21 \mathrm{E}+4$ \\
\hline 70,000 & $4.95 \mathrm{E}+4$ \\
\hline
\end{tabular}


In Table 8-3, we see that adding continual amounts of oxalic acid for Purex sludge dissolution will cause precipitated oxalates to form in the treatment tank. Without adequate slurrying/mixing capability in the tank, these may remain in the treatment tank. For HM sludge dissolution, the similar effect is shown in Table 8-4.

Table 8-4 Solids in HM Sludge Treatment Tank from Excess Oxalic Acid

\begin{tabular}{|c|c|}
\hline Oxalic Acid (kg) & Precipitated Treatment Tank Solids \\
\hline 5000 & $1.03 \mathrm{E}+4$ \\
\hline 10,000 & $4.84 \mathrm{E}+3$ \\
\hline 15,000 & $1.81 \mathrm{E}+3$ \\
\hline 20,000 & $1.94 \mathrm{E}+3$ \\
\hline 25,000 & $1.93 \mathrm{E}+3$ \\
\hline 30,000 & $1.91 \mathrm{E}+3$ \\
\hline 35,000 & $1.30 \mathrm{E}+4$ \\
\hline 40,000 & $2.91 \mathrm{E}+4$ \\
\hline 45,000 & $4.53 \mathrm{E}+4$ \\
\hline 50,000 & $1.03 \mathrm{E}+4$ \\
\hline 55,000 & $4.84 \mathrm{E}+4$ \\
\hline 60,000 & $1.81 \mathrm{E}+4$ \\
\hline 65,000 & $1.94 \mathrm{E}+4$ \\
\hline 70,000 & $1.93 \mathrm{E}+4$ \\
\hline
\end{tabular}

Based on the individual constituent variations in Tables 8-1 and 8-2, the forecasted change in the post pH adjustment sludge mass is shown in Tables 8-5 and 8-6.

Table 8-5 Sensitivity of pH Adjusted Precipitate to Initial Purex Variations

\begin{tabular}{|c|c|c|c|}
\hline Constituent & $\begin{array}{c}\text { Baseline Mass } \\
\text { (kg/per 5K gallon } \\
\text { Heel) }\end{array}$ & $\begin{array}{c} \pm \text { Initial Sludge } \\
\text { Variation } \\
\text { (kg) }\end{array}$ & $\begin{array}{c}\mathbf{\pm} \text { Resulting } \\
\text { Precipitate } \\
\text { Variation } \\
(\mathbf{k g})\end{array}$ \\
\hline $\mathrm{Al}(\mathrm{OH})_{3}$ & 1,430 & 100 & 109 \\
\hline $\mathrm{Fe}(\mathrm{OH})_{3}$ & 5,444 & 100 & 102 \\
\hline $\mathrm{Mn}(\mathrm{OH})_{2}$ & 558 & 100 & 125 \\
\hline $\mathrm{Ni}(\mathrm{OH})_{2}$ & 425 & 100 & 138 \\
\hline $\mathrm{UO} 2(\mathrm{OH})_{2}$ & 929.5 & 100 & 6 \\
\hline $\mathrm{SiO}_{2}$ & 211.6 & 100 & 0.0 \\
\hline $\mathrm{CaCO}_{3}$ & 579 & 100 & 240 \\
\hline $\mathrm{Ce} \mathrm{O}_{3}$ & 22.7 & 100 & 18 \\
\hline $\mathrm{NaNO}$ & 186 & 100 & 6 \\
\hline $\mathrm{NaOH}$ & 592 & 100 & 1.4 \\
\hline
\end{tabular}


Since most of the gas released is expected to be $\mathrm{CO}_{2}$; and the model has been shown to treat $\mathrm{CO}_{2}$ inappropriately, the forecasted impacts from $\mathrm{CaCO}_{3}$ variations in Purex sludge may be over-predicted.

Table 8-6 Sensitivity of pH Adjusted Precipitate to Initial HM Variations

\begin{tabular}{|c|c|c|c|}
\hline Constituent & $\begin{array}{c}\text { Baseline Mass } \\
\text { (kg/per 5,000 } \\
\text { gallon Heel) }\end{array}$ & $\begin{array}{c}\text { Initial Sludge } \\
\text { Variation } \\
\text { (kg) }\end{array}$ & $\begin{array}{c}\text { + Resulting } \\
\text { Precipitate Variation } \\
\text { (kg) }\end{array}$ \\
\hline $\mathrm{Al}(\mathrm{OH})_{3}$ & 5,521 & 100 & 99 \\
\hline $\mathrm{Fe}(\mathrm{OH})_{3}$ & 2,385 & 100 & 99 \\
\hline $\mathrm{Mn}(\mathrm{OH})_{2}$ & 549 & 100 & 129 \\
\hline $\mathrm{Ni}(\mathrm{OH})_{2}$ & 104.2 & 100 & 138 \\
\hline $\mathrm{UO}_{2}(\mathrm{OH})_{2}$ & 287.3 & 100 & 6 \\
\hline $\mathrm{SiO}_{2}$ & 332.5 & 100 & $\mathrm{NA}$ \\
\hline $\mathrm{CaCO}_{3}$ & 579 & 100 & 414 \\
\hline $\mathrm{Ce}_{2} \mathrm{O}_{3}$ & 115.9 & 100 & 28 \\
\hline $\mathrm{NaNO}_{3}$ & 186 & 100 & 5 \\
\hline $\mathrm{ThO}_{2}$ & 104.2 & 100 & 100 \\
\hline $\mathrm{HgO}^{2}$ & 287.3 & 100 & 96 \\
\hline
\end{tabular}

As evidenced in columns 3 and 4 of Tables 8-5 and 8-6, many of the metals are approximated by the same value (i.e., $100 \mathrm{~kg}$ ). This is indicative of the fact that the addition of oxalic acid and subsequent neutralization has the same net effect as the direct addition of sodium oxalate and water.

The additional supernate and oxalate solids added to the adjustment tank from Purex sludge heel dissolution and HM sludge heel dissolution are shown in Tables 87 and 8-8, respectively. 
Table 8-7 Liquid and Solid Increase from Purex Sludge Heel Dissolution

\begin{tabular}{|c|c|c|}
\hline $\begin{array}{c}\text { Oxalic Acid } \\
\text { Addition } \\
\text { (kg) }\end{array}$ & $\begin{array}{c}\text { Additional Supernate } \\
\text { (Gallons) }\end{array}$ & $\begin{array}{c}\text { Net Adjustment } \\
\text { Tank Solids (kg) }\end{array}$ \\
\hline $1.0 \mathrm{E}+4$ & $6.25 \mathrm{E}+3$ & $1.83 \mathrm{E}+4$ \\
\hline $1.5 \mathrm{E}+4$ & $1.25 \mathrm{E}+5$ & $2.58 \mathrm{E}+4$ \\
\hline $2.0 \mathrm{E}+4$ & $1.88 \mathrm{E}+5$ & $3.24 \mathrm{E}+4$ \\
\hline $2.5 \mathrm{E}+4$ & $2.50 \mathrm{E}+5$ & $3.41 \mathrm{E}+4$ \\
\hline $3.0 \mathrm{E}+4$ & $3.13 \mathrm{E}+5$ & $2.28 \mathrm{E}+4$ \\
\hline $3.5 \mathrm{E}+4$ & $3.75 \mathrm{E}+5$ & $2.46 \mathrm{E}+4$ \\
\hline $4.0 \mathrm{E}+4$ & $4.38 \mathrm{E}+5$ & $2.57 \mathrm{E}+4$ \\
\hline $4.5 \mathrm{E}+4$ & $5.00 \mathrm{E}+5$ & $2.57 \mathrm{E}+4$ \\
\hline $5.0 \mathrm{E}+4$ & $5.63 \mathrm{E}+5$ & $2.57 \mathrm{E}+4$ \\
\hline $5.5 \mathrm{E}+4$ & $6.25 \mathrm{E}+5$ & $2.57 \mathrm{E}+4$ \\
\hline $6.0 \mathrm{E}+4$ & $6.88 \mathrm{E}+5$ & $2.58 \mathrm{E}+4$ \\
\hline $6.5 \mathrm{E}+4$ & $7.50 \mathrm{E}+5$ & $2.58 \mathrm{E}+4$ \\
\hline $7.0 \mathrm{E}+4$ & $8.13 \mathrm{E}+5$ & $2.58 \mathrm{E}+4$ \\
\hline
\end{tabular}

Table 8-8 Liquid and Solid Increase from HM Sludge Heel Dissolution

\begin{tabular}{|c|c|c|}
\hline $\begin{array}{c}\text { Oxalic Acid } \\
\text { Added } \\
\text { (kg) }\end{array}$ & $\begin{array}{c}\text { Additional Supernate } \\
\text { (Gallons) }\end{array}$ & $\begin{array}{c}\text { Net Adjustment Tank } \\
\text { Solids } \mathbf{( k g})\end{array}$ \\
\hline $1.0 \mathrm{E}+4$ & $6.25 \mathrm{E}+3$ & $1.76 \mathrm{E}+4$ \\
\hline $1.5 \mathrm{E}+4$ & $1.25 \mathrm{E}+5$ & $2.48 \mathrm{E}+4$ \\
\hline $2.0 \mathrm{E}+4$ & $1.88 \mathrm{E}+5$ & $3.12 \mathrm{E}+4$ \\
\hline $2.5 \mathrm{E}+4$ & $2.50 \mathrm{E}+5$ & $4.13 \mathrm{E}+4$ \\
\hline $3.0 \mathrm{E}+4$ & $3.13 \mathrm{E}+5$ & $4.35 \mathrm{E}+4$ \\
\hline $3.5 \mathrm{E}+4$ & $3.75 \mathrm{E}+5$ & $2.91 \mathrm{E}+4$ \\
\hline $4.0 \mathrm{E}+4$ & $4.38 \mathrm{E}+5$ & $2.91 \mathrm{E}+4$ \\
\hline $4.5 \mathrm{E}+4$ & $5.00 \mathrm{E}+5$ & $2.91 \mathrm{E}+4$ \\
\hline $5.0 \mathrm{E}+4$ & $5.63 \mathrm{E}+5$ & $2.91 \mathrm{E}+4$ \\
\hline $5.5 \mathrm{E}+4$ & $6.25 \mathrm{E}+5$ & $2.91 \mathrm{E}+4$ \\
\hline $6.0 \mathrm{E}+4$ & $6.88 \mathrm{E}+5$ & $2.92 \mathrm{E}+4$ \\
\hline $6.0 \mathrm{E}+4$ & $7.50 \mathrm{E}+5$ & $2.92 \mathrm{E}+4$ \\
\hline $7.0 \mathrm{E}+4$ & $8.13 \mathrm{E}+5$ & $2.92 \mathrm{E}+4$ \\
\hline & & \\
\hline
\end{tabular}




\section{CONCLUSION}

The research design is originally based on extending the applicable acid dissolution sample data in terms of sensitivity analyses and variability analyses. Available OLI ${ }^{\circ}$ software was used as it allows effects on chemistry to be quickly estimated.

The goal of the research was to determine if acid solutions could be used to effectively aid in sludge heel dissolution without:

1) Significantly increasing tank corrosion

2) Creating gas/flammability process hazards

3) Creating undisposable process waste streams

Early on, however, it was determined that both the use of nitric and citric acid could not currently be supported, and research would be limited to the use of oxalic acid. Additionally, there was a fundamental problem with the proposed original SVA approach. The evaluations that were originally proposed could only be accomplished, if the acceptability could be quantitatively based. Instead, almost all of the safety and processability evaluations proved to be qualitative. To meet the research need, instead of building SVAs into the evaluation, SVAs were limited to variations in acid quantities and slight variation in constituents.

The following are evaluated/determined:

1) The model's ability to forecast dissolution effectiveness

2) Possible overpressurization, overheating, and flammability, AND the effect of dissolution on organics and energetic materials

3) A preferred and acceptable processability path]

The results of the research show that overall, sludge heel dissolution, using oxalic acid with subsequent $\mathrm{pH}$ adjustment/restoration, can be effectively modeled. 
For a 5,000-gallon Purex sludge heel, somewhere between 65,000 gallons to 135,000 gallons of $8 w t \%$ oxalic acid should be used. The 65,000 gallons is based on $100 \%$ excess of the equilibrium model, and the 131,000 gallons is based on observed laboratory testing, assuming three strikes of 20:1 volume ratio of $8 w t \%$ acid dissolving $70-50-30 \%$ of the sludge heel volume.

For a 5000 gallon HM sludge heel, somewhere between 85,000 gallons to 135,000 gallons of $8 w t \%$ oxalic acid should be used. The 85,000 gallons is based on $100 \%$ excess of the equilibrium model, and the 135,000 gallons is based on observed laboratory testing assuming a 3-strike 20:1 volume ratio of $8 \mathrm{wt} \%$ acid dissolving 70 $50-30 \%$ of the sludge heel volume.

The maximum expected temperature can be bounded by $73.46^{\circ} \mathrm{C}$, assuming 100,00 gallons of $8 w t \%$ oxalic acid reacts with 5.8 trucks of $50 w t \% \mathrm{NAOH}$. Operational controls, however, could be credited with limiting the temperature to less than $64.62^{\circ} \mathrm{C}$.

Since at $64.62^{\circ} \mathrm{C}$, only 253 liters of $\mathrm{CO}_{2}$, and at $73.5^{\circ} \mathrm{C}$ only 770 liters of water vapor could be generated, overpressurization should not be a problem. The corrosioninduced hydrogen is calculated to be less than $362 \mathrm{ft}^{3} / \mathrm{hr}$. At this rate, because of hydrogen's relatively low flammability, ventilation upgrades and/or additional studies may be required (i.e., only 4 percent is considered the lower flammability limit). Because of the aging of the Tanks 1-15 sludge, and the effects of bulk waste removal, energetics and organics are not believed to represent a significant problem.

Because of the need to minimize glass canisters, the formation of precipitated solids should be minimized. Based on equilibrium modeling approximately three 5000gallon sludge heel treatments can be processed in a sludge batch without a significant increase in glass canisters. The actual number depends largely on the quantity of acid added and the volume of the sludge heel. Based on the model excess in Chapter 7, about 15,000 gallons can be added to a washed sludge batch with minimal impact on the number of additional glass canisters produced. 
For each vitrification sludge batch, where 1 to 3 heel dissolutions have been added, $60,000 \mathrm{kgs}$ of sodium oxalate will enter the evaporator system, with most collecting in the evaporator drop tank, until eventual salt heel removal. Assuming salt heel removal, for each $6,000 \mathrm{~kg}$ of sodium oxalate, about 50,000 gallons of additional dilute Saltstone feed will occur.

Overall, the model and testing show that the amount of sodium oxalate and precipitated solids formed from Purex sludge heel dissolution and HM sludge heel dissolution are generally similar. Since the testing recommends equal quantities of acid for both Purex sludge dissolution and HM sludge dissolution, while equilibrium modeling also shows similar amounts of acid required $(65,000$ gallons for Purex and 85,000 gallons for HM), the processability of the sludge can be considered to be relatively insensitive to variations in constituents. Sludge heel dissolution, with oxalic acid and subsequent pH adjustment/restoration, can be best considered sludge heel relocation with five times more solids.

Assuming the treatment tank is being readied for closure, the flammability issues associated with corrosion induced hydrogen can be overcome and are not significant processing upsets. Ultimately, Tanks 1-15 sludge heel dissolution using oxalic acid seems promising. 


\section{BIBLIOGRAPHY}

A. Anderko, P. Wang P. and M. Rafal, 2002, 'Electrolyte Solutions: From Thermodynamic and Transport Property Models to the Simulation of Industrial Processes,' Fluid Phase Equilibria, 194-1972.

K. Adu-Wusu, M. Barnes, N. Bibler, J. Cantrell, F. Fondeur, B. Hamm, C. Herman, D. Hobbs, E. Ketusky, M. Singleton, M. Stallings, W. Stevens, and B. Wiersma, 9 September 2003, 'Waste Tank Heel Chemical Cleaning Summary,' WSR C-TR-2003-00401, Westinghouse Savannah River Site, South Carolina,

N. Badheka and E. T. Ketusky, 3 December 2003, 'Acid Treatment of Tank Heel, Material Balance of Projected Acid Treatment of HLW Tank Heels,' G-CLC-G00108, Westinghouse Savannah River Site, South Carolina

C. D. Barnes, T. B. Calloway, T and R.E. Eibling, R. E., April 2003, 'Thermodynamic Modeling of the AWE Radioactive Aqueous Waste Treatment Plant Evaporator,' WSRC-TR-2002-00567, Westinghouse Savannah River Site, South Carolina

R.F. Bradley and A. J. Hill, A.J ., May 1977, 'Chemical Dissolving of Sludge from a High Level Waste Tank at the Savannah River Plant,' DP-1471, Savannah River Site, South Carolina

T. E. Britt, 3 March 2003, 'Resolution of Organic PISA,' WS R C-TR-2002-000094, Westinghouse Savannah River Site, South Carolina

T. D. Burns and J.S. Catardi, 19 May 2004, 'Staff Issue Report-Safety Impacts of Suspending Salt Disposition at the Savannah River Site' United States of America- Defense Nuclear Facilities Safety Board, viewed 1 J anuary 2005

D.M. Camaioni, S. T. Autry, and J. Linehan, 9 J une 1999, 'Mechanisms and Kinetics of Organic Aging in HLW Summary Report,' P roject 65408, Hanford Site, Washington

W. Cavin W., and A. Crumm, 9 September 2003, 'Waste Transfers and Miscellaneous Additions,' WSR C-TR-93-425, Westinghouse Savannah River Site, South Carolina

B. A. Davis, 15 April 2004, 'CSTF Flammability Control Program,' WSRC-TR2003-00087, Westinghouse Savannah River Site, South Carolina

DSA, 1 J anuary 2003, 'CST Design Safety Analyses,' WSRC-SA-00007, Westinghouse Savannah River Site, South Carolina

M. R. Elmore, April 1996, 'Fiscal Year 1995 Laboratory Scale Studies of Cs Elution in Tank 8D-1 and Sludge Dissolution in Tank 8D-2,' PNNL-10945, Hanford Site, Washington 
United States Federal Register, 19 August 2002, Vol 67, Number 160, P 5378453787

Fluor Hanford, 10 J uly 2003, 'Laboratory Testing of Oxalic Acid Dissolution of Tank 241-C-106 Sludge,' RP P-17158, Hanford Site, Washington

J. R. Fowler, 22 February 1980, 'Effect of Temperature on Sodium Oxalate Solubility,' DRST-80-265, Westinghouse Savannah River Site, South Carolina

W. J. Gray, and R. E. Westerman, May 1995, 'Laboratory Studies of Gas Generation and Potential for Tank Wall Corrosion During Blending of High-Level Wastes at the West Valley Demonstration Project,' Pacific Northwest National Laboratory, PNL-1051, Hanford River Site, Washington

T. Hang, 6 J une, 2002, 'A Description of Phase-1 High Level Waste Evaporator Flowsheet Models,' WS R C-TR-2002-00268, Westinghouse Savannah River Site, South Carolina

C. Herman and D. Best, 15 November 2002, 'Supplemental Solubility Data for SRAT Processing of Sludge Batch 3 with H Canyon Containing Precipitated Pu and Gd in DWPF' WSR C-TR-2002-00322.

HLW, 1 October 2005, 'Waste Characterization System WCS 1.5, (process database),' Westinghouse Savannah River Site, South Carolina.

D. T. Hobbs, 9 September 1999, 'Possible Explosive Compounds in the Savannah River Site Waste Tank Farm Facilities,' WSRC-TR-92-444, Westinghouse Savannah River Site, South Carolina

D. T. Hobbs, M.E. Stallings, and B.J. Wiersma, 26 March 2004, 'Dissolution of Simulated and Radioactive Savannah River Site High Level Waste Sludge with Oxalic Acid and Citric Acid Solutions,' WSRC-TR-2004-00043, Westinghouse Savannah River Site, South Carolina.

J. L. Huckaby, L.A. Mahoney, J.E. Droppo, and J. E. Meachem, August 2004, 'Overview of Hanford Site High Level Waste Tank Gas and Vapor Dynamics,' PNNL-14831, Pacific Northwest National Laboratory, Washington

B. M. J ohnson, B.M., 1987 'Tank 16 Decommissioning-CAB Basic Data,' DPSP87-1219, Savannah River Site, South Carolina

E. T. Ketusky, 22 J une 2004, 'Impacts of Oxalic Acid Sludge Heel dissolution on HLW Explosive Compounds for Tanks 1-24, 'WSR C-TR-2004-00118,

Westinghouse Savannah River Site, South Carolina

KNOVEL Critical Tables, 2003, last viewed online 10 October 2005.

L. D. Koffman, 2002, 'User Guide for the ACM Evaporator Model User Interface,' WSR C-RR-2002-00324, Westinghouse Savannah River Site, South Carolina 
K.L. Lang, 22 September 2004, 'Bounding Hydrogen Generation Rates For Type I And Type 11 Waste Tanks During Chemical Cleaning Of Sludge Heel With Oxalic Acid,' X-CLC-G-00063, Westinghouse Savannah River Site, South Carolina

G. R. Lilliston, 24 August 2004, 'Washing and Addition Strategies for the Combination of Sludge Batch 4 (Tanks 4, 5, 6, 8, and 11) with Sludge Batch 3 as Feed into DWPF,' CBU-PED-2004-00031, Westinghouse Savannah River Site, South Carolina

H. Metcalf, H., J. Williams, J. Castka, J., and C. Dull, 1978, 1 "Modern Chemistry," Holt, R inehart and Winston.

F. M. Morel, January 1983, "Principles of Aquatic Chemistry" (A Wiley Intersciences Publication), J ohn Wiley \& Sons.

R. S. Ondrejcin, 15 December, 1976, 'Carbon Steel and Stainless Steel Attack from Sludge Dissolution,' DPST-76-471, Westinghouse Savannah River Site, South Carolina

D. Peeler, and T Edwards, 30 November 2002, "P rojected Operating Windows for Various Sludge Batch $2 / 3$ Blends, A progression from the Mar to the PAR, WSRC-TR-2003-00509, Rev. 0, Westinghouse Savannah River Site, South Carolina

J . A. Pike, April 2002, 'Tank 41 Salt Dissolution Flowsheet Modeling,' WS RC-TR2002-00209, Westinghouse Savannah River Site, South Carolina

J. J . P hilips, 30 J uly 2004, 'Carbon Steel Components in Type I and II Tanks and Annuli,' C-CLC-G-00355, Savannah River Site, South Carolina

M. R. Poirer and S. D. Fink, 12 December, 2002, 'Investigation of Alternative for Cleaning Mott Porous Metal Filters,' WSRC-TR-2002-00526, Westinghouse Savannah River Site, South Carolina

R. N. Robinson, G.N. Gutowski, and W. Yeniscavage, November 2003, 'Control of Red Oil Explosions in Defence Nuclear Facilities,' Defence Nuclear Facilities Safety Board Technical Report, DNFSB-TECH-33

H. H. Saito, J uly 2002, 'Regulatory Off-Gas Analysis From the Evaporation of Hanford Simulated Wastes Spiked with Organics,' WSRC-TR-2002-00590, Westinghouse Savannah River Site, South Carolina

R. Sunrammanian, and B. Wiersma, 25 August 2005, 'Corrosion Testing of Carbon Steel in Acid Cleaning Solutions,' WSR C-TR-2002-00427,

Westinghouse Savannah River Site, South Carolina 
R. F. Swingle, J. E. Young, T. A. Nance, Z. H. Qureshi, and S. L. Crump, 1999, 'Analysis of Organic Samples from the 5-H and 3-F Pump Tanks and Waste Tank 38H,' WS R C -TR -99-00188, Westinghouse Savannah River Site, South Carolina

D. D. Walker, 30 September 2002, 'Organic Compounds in the Savannah River Site High Level Waste,' WSRC-TR-2002-00391, Westinghouse Savannah River Site, South Carolina

W. L. West, W.L., December 1980 'Tank 16 Demonstration Wash Water and Chemical Cleaning Results,' DPSP-80-23-17, Savannah River Site, South Carolina

B. J. Wiersma, 1 March 2004, 'Corrosion Mechanisms and Rates for Carbon Steel and Stainless Steel Materials Exposed to Oxalic Acid Solution,' WS RC-TR2004-00109, Westinghouse Savannah River Site, South Carolina

J. R. Wiley, 23 August 1978, 'Sodium Oxalate Solubility in Simulated SRP Waste Solutions,' DPST-78-480, Westinghouse Savannah R iver Site, South Carolina

E. W. Wilde, L. R. Berger, and J. A. Burger, March 1984, 'Cleaning Agents for Reactor Heat Exchangers,' DP-1670, Westinghouse Savannah River Site, South Carolina 
APPENDICES 


\section{Appendix 1 Proof-In-Principle}

\section{A1.1 Modeling Theory}

The free energy relates the effects of the combination of heat, entropy, temperature, and pressure. Gibbs free energy also allows one to determine under what conditions the reaction will proceed, in what direction the reaction will occur, and the position of equilibrium. The free energy can be expressed as Equation A1-1.

$$
G_{i}=G_{i}^{0}+R T(\cdot i m)
$$

Where:

$$
\begin{aligned}
& T=\text { Temperature (Kelvin) } \\
& R=\text { Gas constant } \\
& \cdot{ }_{I}=\text { activity coefficient which captures departure from ideality } \\
& m=\text { concentration unit molarity }
\end{aligned}
$$

At equilibrium, when the reactants and products are at the same temperature and pressure, the sum of the free energy of the products equals the sum of the Gibbs Free Energy of the reactants. Refer to Equation A1-2.

$$
\text { - } \Delta \text { Gproduct }-\cdot \Delta G_{\text {react }}=0
$$

The key to thermodynamic equilibrium is that the phases must be in equilibrium; that is, the species on the left-hand side of the reaction must be equal to the total Gibbs Free Energy on the right hand side of the reaction. Refer to Equation A1-3.

$$
\Delta \mathrm{G}_{\text {right }}=\Delta \mathrm{G}_{\mathrm{left}}
$$

Knowing that the Gibbs Free Energies are equal enables the model to discern when the reaction reaches thermodynamic equilibrium. In this case, thermodynamic equilibriums and sludge dissolutions are considered to have the same starting and stopping points. By comparing the initial mass volume, therefore, to the original volume, we can determine the percent dissolved. 
The OLI's ${ }^{\odot}$ dissolution databank used is based upon published experimental solubility data. The software model uses data regression wherever possible and only estimates and extrapolates as required when determining equilibrium. The software provides general dissolution modeling capability for almost any aqueous chemical mixture entered into the databank within the temperature, pressure, and ionic strength range.

The databank contains thermodynamic, transport, and physical properties for 79 inorganic elements (including actinides, heavy, and precious metals) and their associated aqueous species. The databank also includes over 3,000 organics (including electrolytes, chelates and organo-metallic species).

Accurate and reliable dissolution simulation is possible if solubility data exists for the chemical system. Since the primary sludge contents are of common industrial interest, most of the data is readily available. If commercial data is not adequate, but believed to be important, laboratory dissolution studies could be performed and added to the databank as necessary. Although for other reasons, the fact remains that several such research efforts are ongoing for secondary constituents.

\section{A1.2 Comparisons with Literature}

Although approved models have been constructed using $\mathrm{OLI}^{\odot}$ for $\mathrm{HLW}$ salt dissolution models, the potential validity of the $\mathrm{OLI}^{\odot}$ software is initially tested using a proof in principle method. This test is for casual observers. This is necessary since many individuals not familiar with the $\mathrm{OLI}^{\odot}$ software question the breadth of its database and its over-all acceptability. The purpose of the test is only to show potential acceptability as formal validation, sensitivity, and bounding analyses, and to ensure the applicability of this effort.

To perform the proof in principle, the calculated OLI Stream Analyzer ${ }^{\odot}$ equilibrium constants ( $k_{\mathrm{sp}}$ values) for manganese and iron are compared to referenced equilibrium constants found from literature (Badheka, 2003, p81). The first example considered is the dissolution of $\mathrm{Mn}(\mathrm{OH})_{2}$, which is shown as Equation A1-4. 
$\mathrm{Mn}(\mathrm{OH})_{2} \cdot \mathrm{Mn}^{+2}+(\mathrm{OH})^{-1}$

OLI predicts the $p k_{s p}$ value as $1.4345 \mathrm{E}-13$, where $k_{s p}=-\log \left(p k_{s p}\right)$.

For the dissolution of $\mathrm{Mn}(\mathrm{OH})_{2}$ in water,

$$
\begin{aligned}
& K_{s p, M n(\mathrm{OH})_{2}}=-\log (1.4345 e-13) \\
& K_{s p, M n(\mathrm{OH})_{2}}=12.8433
\end{aligned}
$$

From Badheka [2003:81], $\mathrm{Mn}(\mathrm{OH})_{2}$ has a $\mathrm{k}_{\mathrm{sp}}$ value of 12.72 .

Another example is Iron(III) hydroxide, which from literature, has a $k_{s p}$ value of 38.55. According to OLI Stream Analyzer, Iron(III) Hydroxide has a $k_{s p}$ value of 37.5 which again is considered to be within reasonable limits.

For species that may have several complexes that are soluble in water, refer to Equation A1-5,

$p K_{\mathrm{sp}}=\mathrm{pK}_{1}{ }^{*} \mathrm{pK}_{2}{ }^{*} \mathrm{pK}_{3}{ }^{*} \mathrm{pK}_{\mathrm{n}}$

Where $\mathrm{K}_{1}, \mathrm{~K}_{2}, \mathrm{~K}_{3}$, and $\mathrm{K}_{\mathrm{n}}$ are the equilibrium constants for each of the complexes, and $K_{n}$ represents the equilibrium constant for the $n t h$ complex that is formed. An example is for $\mathrm{Al}(\mathrm{OH})_{3}$. Refer to Equation A1-6 through A1-9.

$$
\begin{aligned}
& \mathrm{Al}(\mathrm{OH})_{3} \cdot \mathrm{Al}^{+3}+(\mathrm{OH})^{-1} \\
& \mathrm{k}_{1}=2.0962 \mathrm{E}-9 \\
& \mathrm{Al}(\mathrm{OH})_{3} \cdot \mathrm{Al}(\mathrm{OH})_{2}^{+1}+(\mathrm{OH})^{-1} \\
& \mathrm{k}_{2}=2.4768 \mathrm{E}-9
\end{aligned}
$$




$$
\begin{aligned}
& \mathrm{Al}(\mathrm{OH})_{3} \cdot \mathrm{Al}(\mathrm{OH})^{+2}+(\mathrm{OH})_{2}^{-1} \\
& \mathrm{k}_{3}=1.0382 \mathrm{E}-9 \\
& \mathrm{Al}(\mathrm{OH})_{3} \cdot \mathrm{Al}(\mathrm{OH})^{-1}+(\mathrm{OH})^{-1} \\
& \mathrm{k}_{4}=7.2826 \mathrm{E}-8
\end{aligned}
$$

Applying the equation for several species that are soluble to the complexes that $\mathrm{Al}(\mathrm{OH})_{3}$ produces in water yields Equations $\mathrm{A} 1-10$ and $\mathrm{A} 1-11$.

$$
\begin{aligned}
& \mathrm{k}_{\mathrm{sp}}=2.0962 \mathrm{E}-9 \times 2.4768 \mathrm{E}-9 \times 1.0382 \mathrm{E}-9 \times 7.2826 \mathrm{E}-8 \\
& \mathrm{k}_{\mathrm{sp}}=3.9255 \mathrm{E}-34
\end{aligned}
$$

From this, the $\mathrm{k}_{\mathrm{sp}}$ value of $\mathrm{Al}(\mathrm{OH})_{3}$ is 33.406. From Badheka [2003:81] the solubility product constant is found to be 32.89 , once again yielding close similarity in the values. Therefore, it is concluded that for the proof in principle tests, the software may provide adequate approximations for $\mathrm{k}_{\mathrm{sp}}$. 
A1.3 Comparisons with Other Simulators

Barnes [2002:55) shows that a detailed comparison for the Aspen Plus ${ }^{\circledR}$ databank and the $\mathrm{OLI}^{\odot}$ databank has been performed for SRS HLW as part of modeling concerns associated with the SRS evaporators. The results of the detailed comparison show that the forecasted behavior of the metal oxides using either Aspen Plus ${ }^{\odot}$ or $\mathrm{OLI}^{\circledR}$ are similar. 


\section{Appendix 2 Validation Miscellaneous}

A2.1 Fate of the Metals

As shown in Chapter 4, the iron oxides will readily dissolve, while aluminum, manganese, and nickel will not. To demonstrate the behavior, using one strike of a $50: 1$ volume ratio of $4 \mathrm{wt} \%$ oxalic acid to Purex simulant, Table A2-1, shows the fate of the iron, aluminum, manganese and nickel oxides.

Table A2-1 Fate of 4 Primary Metal Oxides in Purex Simulant Dissolution

\begin{tabular}{|c|c|c|c|c|}
\hline Initial Compound & (\% mole) & $\begin{array}{c}\text { Final } \\
\text { Compound }\end{array}$ & $\begin{array}{c}\text { Aqueous } \\
\text { (\% mole) }\end{array}$ & $\begin{array}{c}\text { Solid } \\
\text { (\% mole })\end{array}$ \\
\hline $\mathrm{Fe}(\mathrm{OH})_{3}$ & 100 & $\mathrm{FeC}_{2} \mathrm{O}_{4}$ & 100 & 0 \\
\hline \multirow{2}{*}{$\mathrm{Al}(\mathrm{OH})_{3}$} & 100 & $\mathrm{Al}(\mathrm{OH})_{3}$ & 0 & 23 \\
\cline { 3 - 5 } & & $\mathrm{AlO}(\mathrm{OH})$ & 65 & 0 \\
\cline { 3 - 5 } & 100 & $\mathrm{AlPO}_{4}$ & 0 & 12 \\
\hline $\mathrm{Mn}(\mathrm{OH})_{2}$ & & $\mathrm{MnC}_{2} \mathrm{O}_{4}$ & 4 & 0 \\
\cline { 3 - 5 } & 100 & $\mathrm{MnC}_{2} \mathrm{O}_{4} \cdot 2 \mathrm{H}_{2} \mathrm{O}$ & 0 & 96 \\
\hline $\mathrm{Ni}(\mathrm{OH})_{2}$ & $\mathrm{NiC}_{2} \mathrm{O}_{4}$ & $<1$ & $>99$ \\
\hline
\end{tabular}

Table A2-2 shows the fate of the iron, aluminum, manganese and nickel oxides for a similar 1 -strike of a $50: 1$ volume ratio of $4 \mathrm{wt} \%$ oxalic acid solution to HM simulant. 
Table A2-2 Fate of 4 Primary Metal Oxides in HM Simulant Dissolution

\begin{tabular}{|c|c|c|c|c|}
\hline Initial Compound & (\% mole) & $\begin{array}{c}\text { Final } \\
\text { Compound }\end{array}$ & $\begin{array}{c}\text { Aqueous } \\
\text { (\% mole })\end{array}$ & $\begin{array}{c}\text { Solid } \\
\text { (\% mole })\end{array}$ \\
\hline $\mathrm{Fe}(\mathrm{OH})_{3}$ & 100 & $\mathrm{FeC}_{2} \mathrm{O}_{4}$ & 100 & 0 \\
\hline $\mathrm{Al}(\mathrm{OH})_{3}$ & 100 & $\mathrm{Al}(\mathrm{OH})_{3}$ & 0 & 40 \\
\cline { 3 - 5 } & 100 & $\mathrm{AlO}(\mathrm{OH})$ & 60 & 0 \\
\hline $\mathrm{Mn}(\mathrm{OH})_{2}$ & & $\mathrm{MnC}_{2} \mathrm{O}_{4}$ & 45 & 0 \\
\cline { 3 - 5 } & 100 & $\mathrm{MnC}_{2} \mathrm{O}_{4} \cdot 2 \mathrm{H}_{2} \mathrm{O}$ & 0 & 55 \\
\hline $\mathrm{Ni}(\mathrm{OH})_{2}$ & & $\mathrm{NiC}_{2} \mathrm{O}_{4}$ & 10 & 90 \\
\hline
\end{tabular}

As seen above, manganese and nickel form mostly insoluble oxalate compounds. 


\section{APPENDIX 3 SPIKED MATERIAL BALANCE}

Figure A3-1 shows the input used in calculating the spiked material balance.

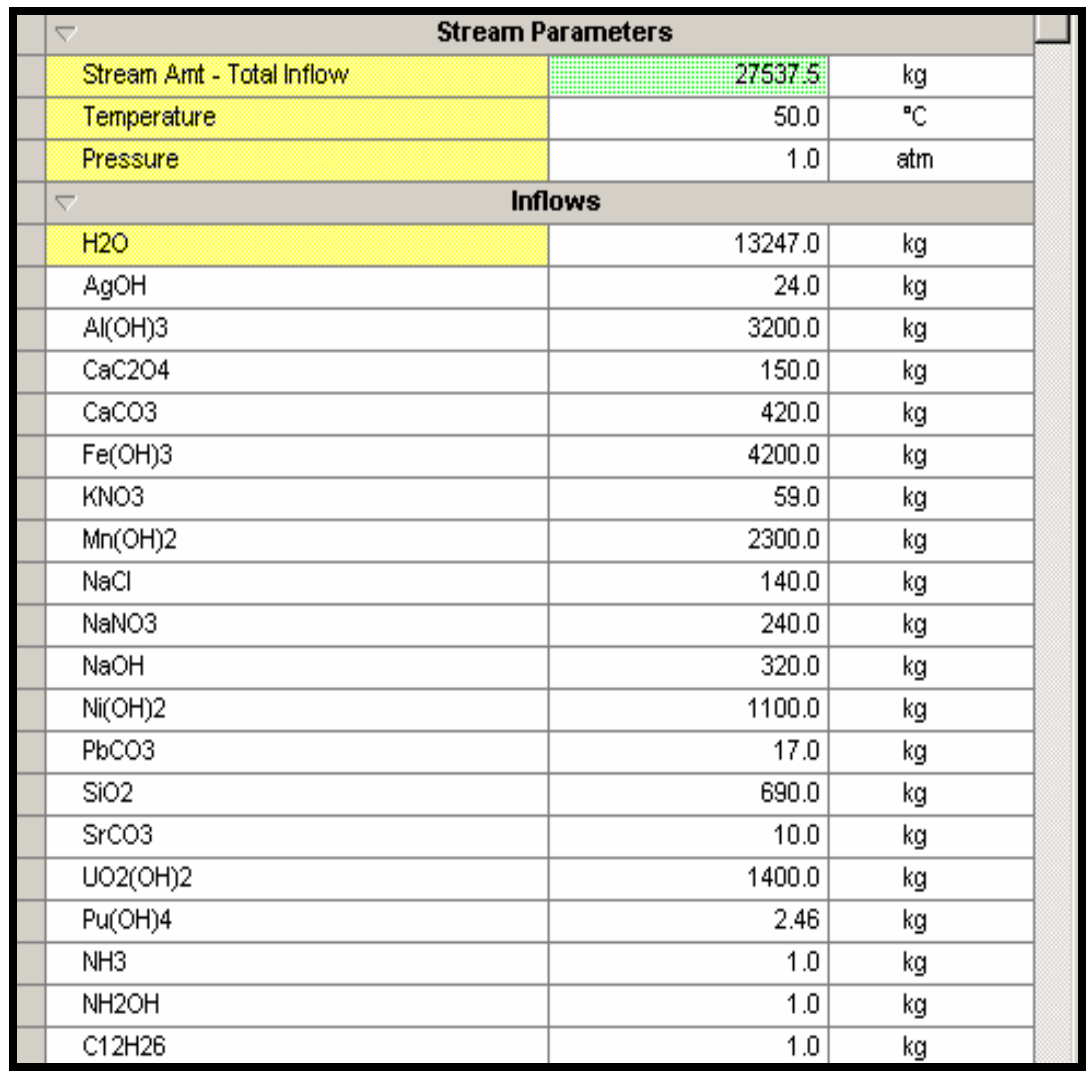

\begin{tabular}{|l|r|l|}
\hline$(\mathrm{C} 4 \mathrm{H} 9) 3 \mathrm{PO} 4$ & 1.0 & $\mathrm{~kg}$ \\
\hline $\mathrm{C6Cl6}$ & 1.0 & $\mathrm{~kg}$ \\
\hline $\mathrm{N} 2 \mathrm{H} 4$ & 1.0 & $\mathrm{~kg}$ \\
\hline $\mathrm{Hg}(\mathrm{CN}) 2$ & 1.0 & $\mathrm{~kg}$ \\
\hline $\mathrm{Ag} 2 \mathrm{O}$ & 1.0 & $\mathrm{~kg}$ \\
\hline $\mathrm{CH} 4$ & 1.0 & $\mathrm{~kg}$ \\
\hline $\mathrm{C} 8 \mathrm{H} 80$ & 1.0 & $\mathrm{~kg}$ \\
\hline $\mathrm{C} 2 \mathrm{H} 402$ & 1.0 & $\mathrm{~kg}$ \\
\hline $\mathrm{AgF} .4 \mathrm{H} 2 \mathrm{O}$ & 1.0 & $\mathrm{~kg}$ \\
\hline $\mathrm{C} 14 \mathrm{H} 2802$ & 1.0 & $\mathrm{~kg}$ \\
\hline $\mathrm{ClO2}$ & 1.0 & $\mathrm{~kg}$ \\
\hline $\mathrm{N}(\mathrm{CN}) 2$ & 1.0 & $\mathrm{~kg}$ \\
\hline $\mathrm{AgCN}$ & 1.0 & $\mathrm{~kg}$ \\
\hline $\mathrm{Ag}[\mathrm{H} 2 \mathrm{C6H6NO6]}$ & 1.0 & $\mathrm{~kg}$ \\
\hline $\mathrm{CH} 3 \mathrm{NO2}$ & 0.0 & $\mathrm{~kg}$ \\
\hline $\mathrm{C} 4 \mathrm{H} 11 \mathrm{~N}$ & 0.0 & $\mathrm{~kg}$ \\
\hline $\mathrm{C} 3 \mathrm{H} 7 \mathrm{NO2}$ & 1.0 & $\mathrm{~kg}$ \\
\hline
\end{tabular}

Figure A3-1 Input Screen for Spiked Material Balance

As an element balance, TableA3-1 shows the fate of the organics and other energetic chemicals added. 
Table A3-1 Fate of Organics and Energetic Materials (Sheet 1 of 3)

\begin{tabular}{|c|c|c|c|c|c|c|}
\hline \multicolumn{7}{|c|}{ First Strike } \\
\hline \multirow[t]{2}{*}{ Constituent } & $\begin{array}{c}\text { Spiked } \\
\text { Aqueous }\end{array}$ & $\begin{array}{c}\text { Spiked } \\
\text { Vapor }\end{array}$ & $\begin{array}{c}\text { Spiked } \\
\text { Solid }\end{array}$ & $\begin{array}{c}\text { Actual } \\
\text { Aqueous }\end{array}$ & $\begin{array}{l}\text { Actual } \\
\text { Vapor }\end{array}$ & $\begin{array}{c}\text { Actual } \\
\text { Solid }\end{array}$ \\
\hline & \multicolumn{6}{|c|}{ (\% mole $)$} \\
\hline $\mathrm{Aq}^{+1}$ & 15.70 & 0.00 & 84.30 & 0.31 & 0.00 & 99.69 \\
\hline $\mathrm{Al}^{+3}$ & 46.63 & 0.00 & 53.37 & 44.90 & 0.00 & 55.10 \\
\hline $\mathrm{C}^{+4}$ & 71.41 & 28.59 & 0.00 & 100 & 0.00 & 0.00 \\
\hline $\mathrm{C}_{12} \mathrm{H}_{26}$ & 0.99 & 99.01 & 0.00 & 0.00 & 0.00 & 0.00 \\
\hline $\mathrm{Ca}^{+2}$ & 42.98 & 0.00 & 57.02 & 26.03 & 0.00 & 73.97 \\
\hline $\mathrm{CH}_{4}$ & 10.98 & 89.02 & 0.00 & 0.00 & 0.00 & 0.00 \\
\hline $\mathrm{Cl}^{-}$ & 92.38 & 0.00 & 7.62 & 92.00 & 0.00 & 8.00 \\
\hline $\mathrm{Cl}_{6} \mathrm{BENZEN}$ & 100.00 & 0.00 & 0.00 & 0.00 & 0.00 & 0.00 \\
\hline $\mathrm{CN}^{-}$ & 100.00 & 0.00 & 0.00 & 0.00 & 0.00 & 0.00 \\
\hline $\mathrm{Cl}^{+4}$ & 94.80 & 5.20 & 0.00 & 0.00 & 0.00 & 0.00 \\
\hline DLALANN $^{-}$ & 100.00 & 0.00 & 0.00 & 0.00 & 0.00 & 0.00 \\
\hline $\mathrm{F}^{-}$ & 100.00 & 0.00 & 0.00 & 0.00 & 0.00 & 0.00 \\
\hline $\mathrm{Fe}^{+3}$ & 100.00 & 0.00 & 0.00 & 100.00 & 0.00 & 0.00 \\
\hline $\mathrm{H}^{+}$ & 99.05 & 0.00 & 0.95 & 98.73 & 0.00 & 1.27 \\
\hline HDROXAMN & 100.00 & 0.00 & 0.00 & 0.00 & 0.00 & 0.00 \\
\hline $\mathrm{Hg}^{+2}$ & 100.00 & 0.00 & 0.00 & 100.00 & 0.00 & 0.00 \\
\hline $\mathrm{K}^{+}$ & 100.00 & 0.00 & 0.00 & 100.00 & 0.00 & 0.00 \\
\hline MEFORMATE & 97.21 & 2.79 & 0.00 & 0.00 & 0.00 & 0.00 \\
\hline $\mathrm{Mn}^{+2}$ & 5.76 & 0.00 & 94.24 & 4.00 & 0.00 & 96.00 \\
\hline $\mathrm{N}+5$ & 100.00 & 0.00 & 0.00 & 100.00 & 0.00 & 0.00 \\
\hline $\mathrm{N}^{-2}$ & 100.00 & 0.00 & 0.00 & 0.00 & 0.00 & 0.00 \\
\hline$N^{-3}$ & 100.00 & 0.00 & 0.00 & 0.00 & 0.00 & 0.00 \\
\hline $\mathrm{Na}^{+}$ & 100.00 & 0.00 & 0.00 & 100.00 & 0.00 & 0.00 \\
\hline $\mathrm{NI}^{+2}$ & 0.51 & 0.00 & 99.49 & 0.27 & 0.00 & 99.73 \\
\hline NTA $^{-3}$ & 100.00 & 0.00 & 0.00 & 0.00 & 0.00 & 0.00 \\
\hline $\mathrm{O}^{-2}$ & 98.42 & 0.03 & 1.55 & 98.09 & 0.00 & 1.91 \\
\hline OXALAT ${ }^{-2}$ & 71.72 & 0.00 & 28.28 & 70.09 & 0.00 & 29.91 \\
\hline $\mathrm{Pb}^{+2}$ & 98.89 & 0.00 & 1.11 & 52.95 & 0.00 & 47.05 \\
\hline $\mathrm{Pu}^{+4}$ & 3.17 & 0.00 & 96.83 & 2.17 & 0.00 & 97.83 \\
\hline $\mathrm{SI}^{+4}$ & 3.22 & 0.00 & 96.78 & 2.46 & 0.00 & 97.54 \\
\hline $\mathrm{Sr}^{+2}$ & 100.00 & 0.00 & 0.00 & 100.00 & 0.00 & 0.00 \\
\hline STYRENOX & 99.90 & 0.10 & 0.00 & 0.00 & 0.00 & 0.00 \\
\hline TBP & 100.00 & 0.00 & 0.00 & 0.00 & 0.00 & 0.00 \\
\hline TEDEAC $^{-}$ & 100.00 & 0.00 & 0.00 & 0.00 & 0.00 & 0.00 \\
\hline $\mathrm{U}^{+6}$ & 94.28 & 0.00 & 5.72 & 75.65 & 0.00 & 24.35 \\
\hline
\end{tabular}


Table A3-1 Fate of Organics and Energetic Materials Continued (Sheet 2 of 3)

\begin{tabular}{|c|c|c|c|c|c|c|}
\hline Constituent & $\begin{array}{c}\text { Spiked } \\
\text { Aqueous }\end{array}$ & $\begin{array}{c}\text { Spiked } \\
\text { Vapor }\end{array}$ & $\begin{array}{c}\text { Spiked } \\
\text { Solid }\end{array}$ & $\begin{array}{c}\text { Actual } \\
\text { Aqueous }\end{array}$ & $\begin{array}{c}\text { Actual } \\
\text { Vapor }\end{array}$ & $\begin{array}{c}\text { Actual } \\
\text { Solid }\end{array}$ \\
\hline \multicolumn{6}{c|}{$(\%$ mole $)$} \\
\hline
\end{tabular}

\begin{tabular}{|l|c|c|c|c|c|c|}
\hline \multicolumn{7}{|c|}{ Second Strike } \\
\hline $\mathrm{Ag}^{+1}$ & 1.60 & 0.00 & 98.40 & 1.53 & 0.00 & 98.47 \\
$\mathrm{Al}^{+3}$ & 85.21 & 0.00 & 14.79 & 82.47 & 0.00 & 17.53 \\
$\mathrm{Ca}^{+2}$ & 0.01 & 0.00 & 99.99 & 0.01 & 0.00 & 99.99 \\
$\mathrm{Cl}^{-1}$ & 1.60 & 0.00 & 98.40 & 1.53 & 0.00 & 98.47 \\
$\mathrm{CL}_{6} \mathrm{BENZEN}$ & 0.01 & 0.00 & 99.99 & 0.0 & 0.0 & 0.0 \\
$\mathrm{H}^{+1}$ & 96.41 & 0.00 & 3.59 & 28.53 & 0.00 & 71.47 \\
$\mathrm{Mn}^{+2}$ & 28.57 & 0.00 & 71.43 & 0.07 & 0.00 & 99.93 \\
$\mathrm{NI}^{+2}$ & 0.07 & 0.00 & 99.93 & 94.93 & 0.00 & 5.07 \\
$\mathrm{O}^{-2}$ & 95.04 & 0.00 & 4.96 & 53.50 & 0.00 & 46.5 \\
$\mathrm{OXALATE}^{-2}$ & 53.53 & 0.00 & 46.47 & 16.37 & 0.00 & 83.63 \\
$\mathrm{~Pb}^{+2}$ & 16.39 & 0.00 & 83.61 & 100.0 & 0.00 & 0.00 \\
$\mathrm{Pu}^{+4}$ & 100.0 & 0.00 & 0.00 & 0.40 & 0.00 & 99.60 \\
$\mathrm{SI}^{+4}$ & 0.40 & 0.00 & 99.60 & 100.0 & 0.00 & 0.00 \\
$\mathrm{U}^{+6}$ & 100.0 & 0.00 & 0.00 & 100.0 & 0.00 & 0.00 \\
\hline \multicolumn{7}{|c|}{ Third Strike } \\
\hline $\mathrm{Ag}^{+}$ & 0.66 & 0.00 & 99.34 & 0.66 & 0.00 & 99.34 \\
$\mathrm{Al}^{+3}$ & 100.0 & 0.00 & 0.00 & 100.0 & 0.00 & 0.00 \\
$\mathrm{Ca}^{+2}$ & 0.01 & 0.00 & 99.99 & 1.07 & 0.00 & 98.93 \\
$\mathrm{Cl}^{-}$ & 0.46 & 0.00 & 99.54 & 0.66 & 0.00 & 99.34 \\
$\mathrm{CL}_{6} \mathrm{BENZEN}$ & 0.66 & 0.00 & 99.34 & 0.00 & 0.00 & 0.00 \\
$\mathrm{H}^{+}$ & 94.93 & 0.00 & 5.07 & 97.93 & 0.00 & 2.07 \\
$\mathrm{Mn}^{+2}$ & 30.68 & 0.00 & 69.32 & 0.65 & 0.00 & 99.35 \\
$\mathrm{NI}^{+2}$ & 0.03 & 0.00 & 99.97 & 0.08 & 0.00 & 99.92 \\
$\mathrm{O}^{-2}$ & 94.03 & 0.00 & 5.97 & 97.18 & 0.00 & 2.82 \\
$\mathrm{OXALATE}^{-2}$ & 42.68 & 0.00 & 57.32 & 60.37 & 0.00 & 39.63 \\
$\mathrm{~Pb}^{+2}$ & 24.39 & 0.00 & 75.61 & 42.39 & 0.00 & 57.61 \\
$\mathrm{SI}^{+4}$ & 3.46 & 0.00 & 96.54 & 0.87 & 0.00 & 99.13 \\
\hline
\end{tabular}


Table A3-1 Fate of Organics and Energetic Materials Continued (Sheet 3 of 3)

\begin{tabular}{|c|c|c|c|c|c|c|}
\hline \multicolumn{7}{|c|}{ pH Adjustment } \\
\hline Constituent & & & $(\%$ & & & \\
\hline $\mathrm{Aq}^{+}$ & 68.80 & 0.00 & 31.20 & 68.80 & 0.00 & 31.20 \\
\hline $\mathrm{Al}^{+3}$ & 26.49 & 0.00 & 73.51 & 0.00 & 0.00 & 100.0 \\
\hline $\mathrm{C}^{+4}$ & 99.32 & 0.00 & 0.68 & 99.32 & 0.00 & 0.68 \\
\hline $\mathrm{C}_{12} \mathrm{H}_{26}$ & 100.0 & 0.00 & 0.00 & 0.00 & 0.00 & 0.00 \\
\hline $\mathrm{Ca}^{+2}$ & 0.43 & 0.00 & 99.57 & 0.00 & 0.00 & 0.00 \\
\hline $\mathrm{CH}_{4}$ & 100.0 & 0.00 & 0.00 & 0.00 & 0.00 & 0.00 \\
\hline $\mathrm{Cl}^{-}$ & 100.0 & 0.00 & 0.00 & 100.0 & 0.00 & 0.00 \\
\hline $\mathrm{Cl}_{6} \mathrm{BENZEN}$ & 0.13 & 0.00 & 99.87 & 0.00 & 0.00 & 0.00 \\
\hline $\mathrm{CN}^{-}$ & 100.0 & 0.00 & 0.00 & 100.0 & 0.00 & 0.00 \\
\hline $\mathrm{Cl}^{+4}$ & 100.0 & 0.00 & 0.00 & 100.0 & 0.00 & 0.00 \\
\hline DLALANN $^{-}$ & 100.0 & 0.00 & 0.00 & 0.00 & 0.00 & 0.00 \\
\hline $\mathrm{F}^{-}$ & 100.00 & 0.00 & 0.00 & 100.00 & 0.00 & 0.00 \\
\hline $\mathrm{Fe}^{+3}$ & 0.93 & 0.00 & 99.07 & 0.93 & 0.00 & 99.07 \\
\hline $\mathrm{H}^{+}$ & 99.15 & 0.00 & 0.85 & 99.15 & 0.00 & 0.85 \\
\hline HDROXAMN & 100.00 & 0.00 & 0.00 & 0.00 & 0.00 & 0.00 \\
\hline $\mathrm{Hg}^{+2}$ & 55.54 & 0.00 & 44.46 & 55.54 & 0.00 & 44.46 \\
\hline $\mathrm{K}^{+1}$ & 100.00 & 0.00 & 0.00 & 100.00 & 0.00 & 0.00 \\
\hline MEFORMATE & 100.00 & 0.00 & 0.00 & 0.00 & 0.00 & 0.00 \\
\hline $\mathrm{Mn}^{+2}$ & 0.35 & 0.00 & 99.65 & 0.35 & 0.00 & 99.65 \\
\hline $\mathrm{N}^{+3}$ & 100.00 & 0.00 & 0.00 & 100.00 & 0.00 & 0.00 \\
\hline $\mathrm{N}^{+5}$ & 100.00 & 0.00 & 0.00 & 100.00 & 0.00 & 0.00 \\
\hline $\mathrm{N}^{-2}$ & 100.00 & 0.00 & 0.00 & 100.00 & 0.00 & 0.00 \\
\hline $\mathrm{N}^{-3}$ & 100.00 & 0.00 & 0.00 & 100.00 & 0.00 & 0.00 \\
\hline $\mathrm{Na}^{+}$ & 54.53 & 0.00 & 45.47 & 54.53 & 0.00 & 45.47 \\
\hline $\mathrm{NI}^{+2}$ & 4.76 & 0.00 & 95.24 & 4.76 & 0.00 & 95.24 \\
\hline NTA $^{-3}$ & 100.00 & 0.00 & 0.00 & 0.00 & 0.00 & 0.00 \\
\hline $\mathrm{O}^{-2}$ & 98.34 & 0.00 & 1.66 & 98.34 & 0.00 & 1.66 \\
\hline OXALATE $^{-2}$ & 5.53 & 0.00 & 94.47 & 5.53 & 0.00 & 94.47 \\
\hline $\mathrm{Pb}^{+2}$ & 100.00 & 0.00 & 0.00 & 100.00 & 0.00 & 0.00 \\
\hline $\mathrm{Pu}^{+4}$ & 0.00 & 0.00 & 100.00 & 0.00 & 0.00 & 100.00 \\
\hline $\mathrm{SI}^{+4}$ & 100.00 & 0.00 & 0.00 & 100.00 & 0.00 & 0.00 \\
\hline $\mathrm{Sr}^{+2}$ & 2.55 & 0.00 & 97.45 & 0.00 & 0.00 & 100.00 \\
\hline STYRENOX & 100.00 & 0.00 & 0.00 & 0.00 & 0.00 & 0.00 \\
\hline TBP & 100.00 & 0.00 & 0.00 & 0.00 & 0.00 & 0.00 \\
\hline TEDEAC ${ }^{-}$ & 100.00 & 0.00 & 0.00 & 0.00 & 0.00 & 0.00 \\
\hline $\mathrm{U}^{+6}$ & 0.05 & 0.00 & 99.95 & 0.05 & 0.00 & 99.95 \\
\hline
\end{tabular}

As seen in the first acid strike, more vapors are given off if organics and miscellaneous vapors are present, as expected. Notably, metals will also behave somewhat differently with organics. 


\section{APPENDIX 4 PROCESS MODELING SPECIFICS}

A4.1 Heel Process Model Description

The unique portion of the sludge heel dissolution process is modeled using OLI ESP ${ }^{\complement}$

Figure A4-1 is a schematic of the OLI ESP ${ }^{\complement}$ model.

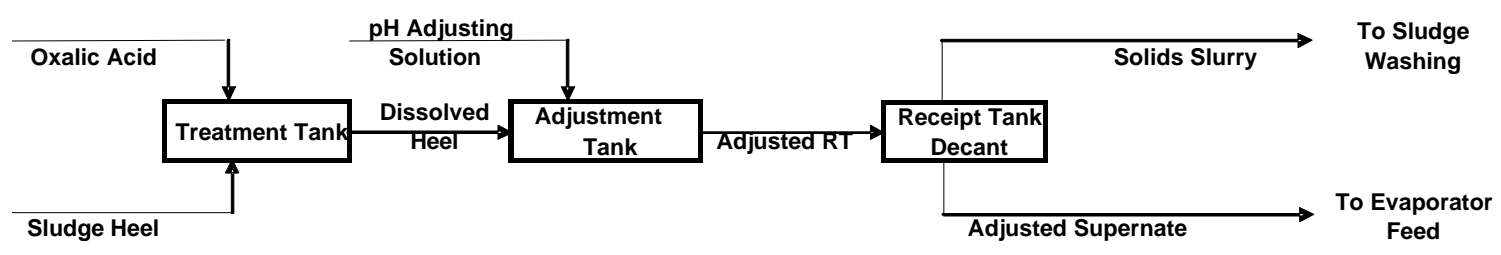

Figure A4-1 Schematic of the Sludge Heel Dissolution Process

\section{A4.1.1 Treatment Tank}

The Treatment Tank is designed as a Mixer Block. Two streams enter the mixer block: Oxalic Acid and Sludge Heel. The oxalic acid stream has an initial starting temperature of $30^{\circ} \mathrm{C}$, a pressure of $1 \mathrm{~atm}$, and has a composition that is $8 \mathrm{wt} \%$ oxalic acid. The amount of oxalic acid required is dependent on the type of waste being dissolved.

This calculation is performed as an isothermal calculation with a final temperature of $30^{\circ} \mathrm{C}$. The resultant stream is named Dissolved Heel. This stream is fed into the next block, the Adjustment Tank, where $\mathrm{pH}$ adjustment of the dissolved heel is performed.

\section{A4.1.2 Adjustment Tank}

The Adjustment Tank is also designed as a Mixer Block. Two streams enter into this block: Dissolved Heel and pH Adjusting (Adjustment) Solution. The stream 
Adjusting Solution can represent either 50 wt\% caustic (50 wt\% $\mathrm{NaOH}$ and 50 wt\% $\mathrm{H}_{2} \mathrm{O}$ ) or average supernate, as defined in Chapter 7 and Appendix 5. This calculation is performed as an isothermal calculation with a final temperature of $30^{\circ} \mathrm{C}$. The resultant stream from the adjustment tank is called the Adjusted RT. This stream is fed into a Separate Block named Adjustment Tank Decant.

\section{A4.1.3 Adjustment Tank Decant}

The Adjustment Tank Decant is a separate block. The resultant stream from the Adjustment Tank Mixer block is fed into this block so that the majority of the liquid can be separated from the solids. The stream name of the solids is called Solids Slurry while the liquid has a stream name of $(\mathrm{pH})$ Adjustment Supernate. The calculation is performed as an entrainment calculation such that the stream Solids Slurry contains 16.7 wt $\%$ solids.

At this point, the unique portion of the sludge heel dissolution model is completed. The stream Adjustment Supernate is then ran through the existing evaporator process model, while the stream Solids Slurry is ran through the existing sludge washing model.

\section{A4.2 Dissolution Chemistry}

The reactions of oxalic acid with sludge are dependent upon the chemical species of the various elements that make up the sludge (and therefore vary by sludge type). Reactions for dissolution of some of these substances with oxalic acid are shown in Table A4-1. 
Table A4-1 Oxalic Acid Reactions with Sludge Components

\begin{tabular}{|c|c|c|}
\hline Reaction & Reactants & Products \\
\hline 1 & $2 \mathrm{AlOOH}+3 \mathrm{H}_{2} \mathrm{C}_{2} \mathrm{O}_{4}$ & $\begin{array}{l}\mathrm{Al}_{2}\left(\mathrm{C}_{2} \mathrm{O}_{4}\right)_{3}+4 \mathrm{H}_{2} \mathrm{O} \\
\left(\mathrm{Al}^{+3} \text { also appears in solution) }\right.\end{array}$ \\
\hline 2 & $2 \mathrm{Al}(\mathrm{OH})_{3}+3 \mathrm{H}_{2} \mathrm{C}_{2} \mathrm{O}_{4}$ & $\mathrm{Al}_{2}\left(\mathrm{C}_{2} \mathrm{O}_{4}\right)_{3}+6 \mathrm{H}_{2} \mathrm{O}$ \\
\hline 3 & $\mathrm{FeO}+\mathrm{H}_{2} \mathrm{C}_{2} \mathrm{O}_{4}$ & $\mathrm{FeC}_{2} \mathrm{O}_{4}+\mathrm{H}_{2} \mathrm{O}$ \\
\hline 4 & $\mathrm{Fe}(\mathrm{OH})_{3}+3 / 2 \mathrm{H}_{2} \mathrm{C}_{2} \mathrm{O}_{4}$ & $\begin{array}{l}\mathrm{FeC}_{2} \mathrm{O}_{4}+\mathrm{CO}_{2}+3 \mathrm{H}_{2} \mathrm{O} \\
\text { (ferrihydrite reaction) }\end{array}$ \\
\hline 5 & $\mathrm{FeOOH}+3 / 2 \mathrm{H}_{2} \mathrm{C}_{2} \mathrm{O}_{4}$ & $\begin{array}{l}\mathrm{FeC}_{2} \mathrm{O}_{4}+\mathrm{CO}_{2}+2 \mathrm{H}_{2} \mathrm{O} \\
\text { (goethite reaction) }\end{array}$ \\
\hline 6 & $\mathrm{Fe}_{2} \mathrm{O}_{3}+3 \mathrm{H}_{2} \mathrm{C}_{2} \mathrm{O}_{4}$ & $\begin{array}{l}\mathrm{Fe}_{2}\left(\mathrm{C}_{2} \mathrm{O}_{4}\right)_{3}+3 \mathrm{H}_{2} \mathrm{O} \\
\text { (hematite reaction) }\end{array}$ \\
\hline 7 & $\mathrm{Fe}_{3} \mathrm{O}_{4}+4 \mathrm{H}_{2} \mathrm{C}_{2} \mathrm{O}_{4}$ & $\begin{array}{l}\mathrm{Fe}_{2}\left(\mathrm{C}_{2} \mathrm{O}_{4}\right)_{3}+\mathrm{FeC}_{2} \mathrm{O}_{4}+4 \mathrm{H}_{2} \mathrm{O} \\
\text { (magnetite reaction) }\end{array}$ \\
\hline 8 & $\mathrm{Fe}_{2} \mathrm{O}_{3}+2 \mathrm{H}_{2} \mathrm{C}_{2} \mathrm{O}_{4}$ & $\begin{array}{l}2 \mathrm{Fe}\left(\mathrm{C}_{2} \mathrm{O}_{4}\right)_{3}+\mathrm{H}_{2} \mathrm{O}+\mathrm{O}_{2} \\
\text { (complexing) }\end{array}$ \\
\hline 9 & $\mathrm{MnO}+\mathrm{H}_{2} \mathrm{C}_{2} \mathrm{O}_{4}$ & $\begin{array}{l}\mathrm{Mn}\left(\mathrm{C}_{2} \mathrm{O}_{4}\right)_{3}+1 / 2 \mathrm{O}_{2} \\
\text { (complexing) }\end{array}$ \\
\hline 10 & $\mathrm{Mn}_{2} \mathrm{O}_{3}+2 \mathrm{H}_{2} \mathrm{C}_{2} \mathrm{O}_{4}$ & $2 \mathrm{Mn}\left(\mathrm{C}_{2} \mathrm{O}_{4}\right)+2 \mathrm{H}_{2} \mathrm{O}+1 / 2 \mathrm{O}_{2}$ \\
\hline 11 & $\mathrm{Mn}_{3} \mathrm{O}_{4}+3 \mathrm{H}_{2} \mathrm{C}_{2} \mathrm{O}_{4}$ & $3 \mathrm{Mn}\left(\mathrm{C}_{2} \mathrm{O}_{4}\right)+3 \mathrm{H}_{2} \mathrm{O}+1 / 2 \mathrm{O}_{2}$ \\
\hline 12 & $\begin{array}{l}\mathrm{H}_{2} \mathrm{C}_{2} \mathrm{O}_{4}+\mathrm{NaNO}_{2}+ \\
1 / 2 \mathrm{O}_{2}\end{array}$ & $\mathrm{NO}+\mathrm{NaNO}_{3}+2 \mathrm{CO}+\mathrm{H}_{2} \mathrm{O}$ \\
\hline 13 & $\mathrm{H}_{2} \mathrm{C}_{2} \mathrm{O}_{4}+\mathrm{Na}_{2} \mathrm{CO}_{3}$ & $\mathrm{Na}_{2} \mathrm{C}_{2} \mathrm{O}_{4}$ (soluble) $+\mathrm{CO}_{2}+\mathrm{H}_{2} \mathrm{O}$ \\
\hline
\end{tabular}

SRS sludge waste consists primarily of two types of sludges, HM sludge and Purex sludge. The HM sludge is higher in aluminum, and the Purex is higher in iron. The primary components of each sludge type, as well as the relative ratio of oxalic acid consumed, are shown in Table A4-1 through A4-3. Table A4-4 shows the equivalent composition and ratios for Tank 16 sludge specifically. These data range from 0.4 to 8 moles of acid per kg of sludge slurry. The ratio of acid consumed per mass of sludge slurry is highly dependent on solids concentration measured or assumed in the sludge slurry. 
Table A4-2 Oxalic Acid Needed to React with $1 \mathrm{~kg}$ of HM Sludge

\begin{tabular}{|c|c|c|}
\hline Constituent & $\begin{array}{c}\text { Mass } \\
(\mathbf{g})\end{array}$ & $\begin{array}{c}\text { Oxalic Acid Needed } \\
\text { (moles) }\end{array}$ \\
\hline $\mathrm{Al}(\mathrm{OH})_{3}$ & 330 & 6.3 \\
\hline $\mathrm{Fe}_{2} \mathrm{O}_{3}$ & 41 & 0.5 \\
\hline $\mathrm{MnO}$ & 19 & 0.3 \\
\hline $\mathrm{NiO}$ & 5 & 0.1 \\
\hline $\mathrm{HM} \mathrm{Sludge}$ & 1000 & 7.2 \\
\hline
\end{tabular}

Table A4-3 Oxalic Acid Needed to React with $1 \mathrm{~kg}$ of PUREX Sludge

\begin{tabular}{|c|c|c|}
\hline Constituent & $\begin{array}{c}\text { Mass } \\
(\mathbf{g})\end{array}$ & $\begin{array}{c}\text { Oxalic Acid Needed } \\
\text { (moles) }\end{array}$ \\
\hline $\mathrm{Al}(\mathrm{OH})_{3}$ & 3 & 0.06 \\
\hline $\mathrm{Fe}_{2} \mathrm{O}_{3}$ & 19 & 0.24 \\
\hline $\mathrm{MnO}$ & 3.7 & 0.05 \\
\hline $\mathrm{NiO}$ & 3.8 & 0.05 \\
\hline PUREX Sludge & 1000 & 0.4 \\
\hline
\end{tabular}


Table A4-4 Oxalic Acid Needed to React with $1 \mathrm{~kg}$ of Tank 16 Sludge

\begin{tabular}{|c|c|c|c|c|}
\hline Constituent & $\begin{array}{c}\text { Molecular Weight } \\
\text { (g/mole) }\end{array}$ & wt\% & $\begin{array}{c}\text { moles per 1 kg of } \\
\text { sludge solids }\end{array}$ & $\begin{array}{c}\text { Oxalic } \\
\text { Acid } \\
\text { (moles) }\end{array}$ \\
\hline $\mathrm{AlO}_{2}^{-}$ & 59 & 16 & 2.71 & 4.07 \\
\hline $\mathrm{Fe}^{+3}$ & 56 & 40 & 7.14 & 7.14 \\
\hline $\mathrm{MnO}_{2}$ & 87 & 16 & 1.84 & 1.84 \\
\hline $\mathrm{Na}^{+}$ & 23 & 20 & 8.70 & 4.35 \\
\hline $\mathrm{SO}_{4}{ }^{-2}$ & 96 & 1.1 & 0.11 & \\
\hline $\mathrm{Si}^{+4}$ & 28 & 2 & 0.71 & 1.43 \\
\hline $\mathrm{Ba}^{+2}$ & 137 & 1 & 0.07 & 0.07 \\
\hline $\mathrm{Ca}^{+2}$ & 40 & 1 & 0.25 & 0.25 \\
\hline $\mathrm{Ce}^{+4}$ & 140 & 1 & 0.07 & 0.14 \\
\hline $\mathrm{Hg}^{+2}$ & 201 & 2.5 & 0.12 & 0.12 \\
\hline $\mathrm{UO}_{2}{ }^{+2}$ & 270 & 0.4 & 0.01 & 0.04 \\
\hline \hline $\mathrm{Total}$ & & 101 & 21.75 & 19.46 \\
\hline
\end{tabular}

\begin{tabular}{|r|r|}
\hline solids wt\%: & 40 \\
\hline slurry sp.g. & 1.2 \\
\hline wt solids per L slurry & $0.48 \mathrm{~kg}$ \\
\hline moles reactive sludge & \\
per kg slurry & 8.70 \\
\hline moles OA reacted & 7.78 \\
\hline
\end{tabular}




\section{APPENDIX 5 DOWNSTREAM PROCESSING RESULTS}

The OLI ESPC simulation of the entire HLW process is modeled for using supernate and $\mathrm{NaOH}$ to $\mathrm{pH}$ adjust the spent/excess oxalic acid for the dissolved Tanks 8 and 11 materials. Figure A5-1 shows the process diagram.

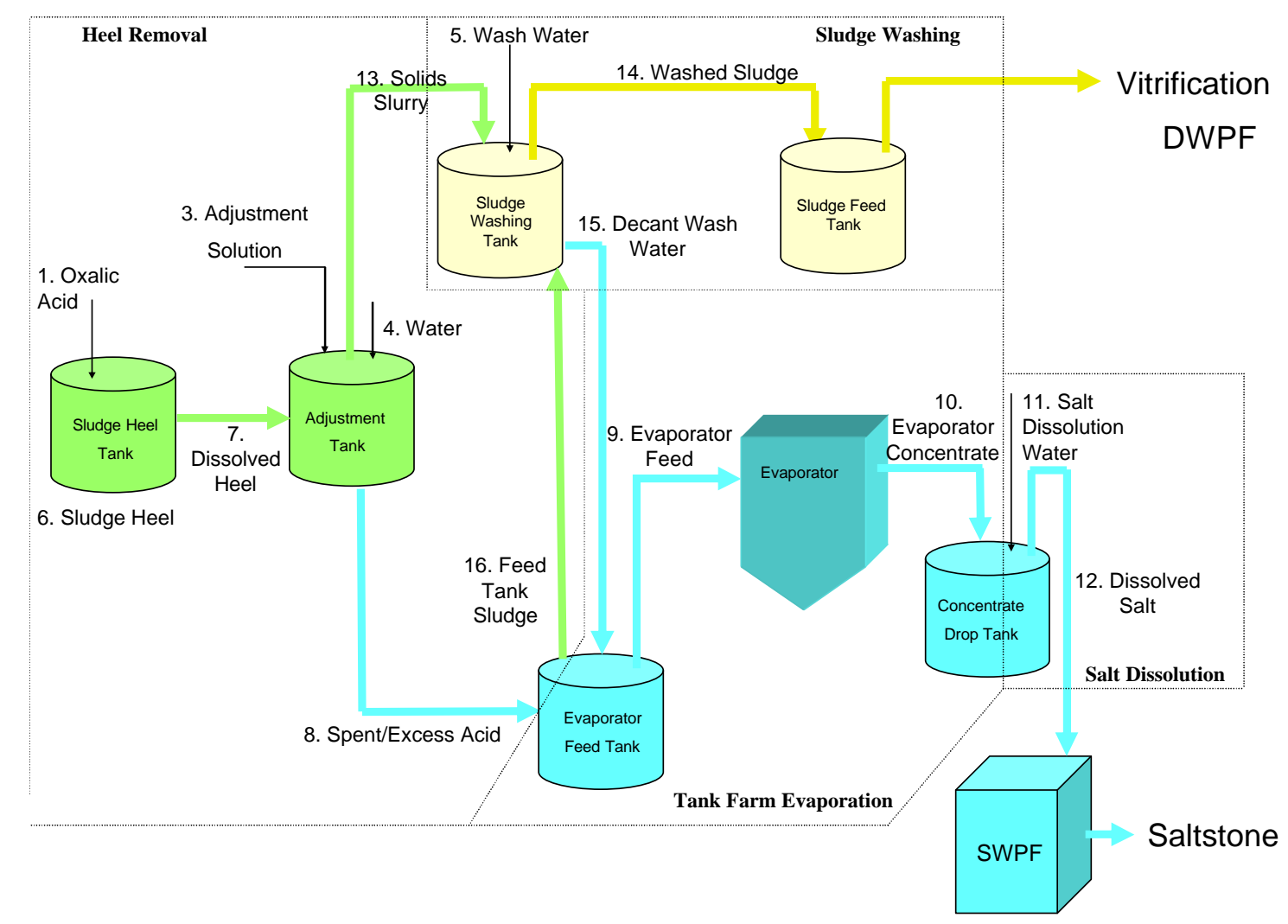

Figure A5-1 Sludge Heel Dissolution Process Diagram 
Tables A5-1 and Table A5-3 show the material balance of the heel dissolution for these tanks using $50 \mathrm{wt} \% \mathrm{NaOH}$ solution for pH adjustment of the acid. Table A5-2 and Table A5-4 show the same material balance using an average supernate for pH adjustment. Note that Tables A5-1 through A5-2 show the added materials, not necessarily existing tank farm material; thus, streams $9,10,12,14$, and 16 show only a material balance for added sodium oxalate. Stream 12 shows zero sodium oxalate transferred, because $100 \%$ remains in the heel. 
Table A5-1 Tank 8 Purex Dissolution Material Balance, pH Adj. w/ NaOH (Case\#1- Sheet 1 of 4)

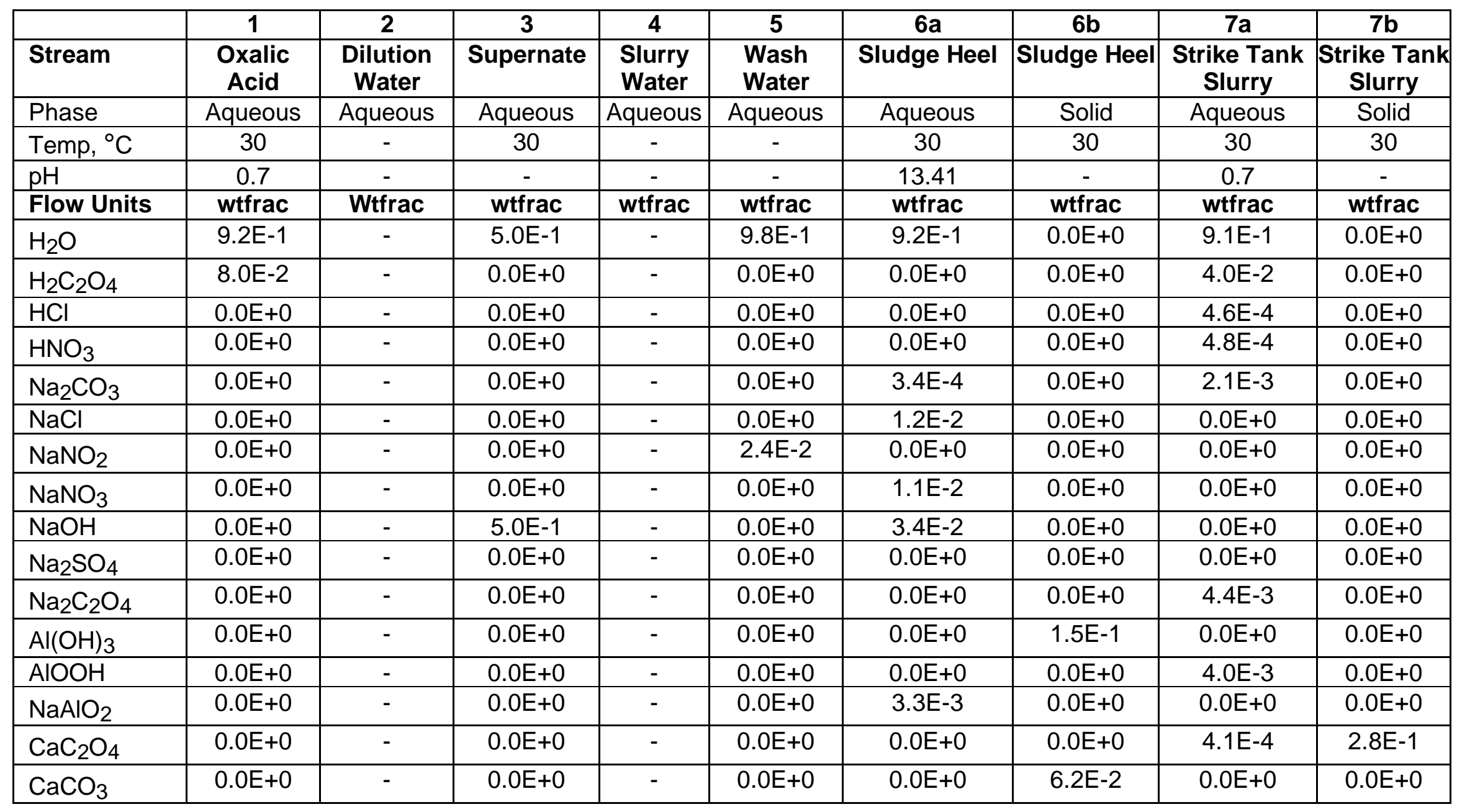


Table A5-1 Tank 8 Purex Dissolution Material Balance, pH Adj. w/ NaOH (Case \#1 - Sheet 2 of 4)

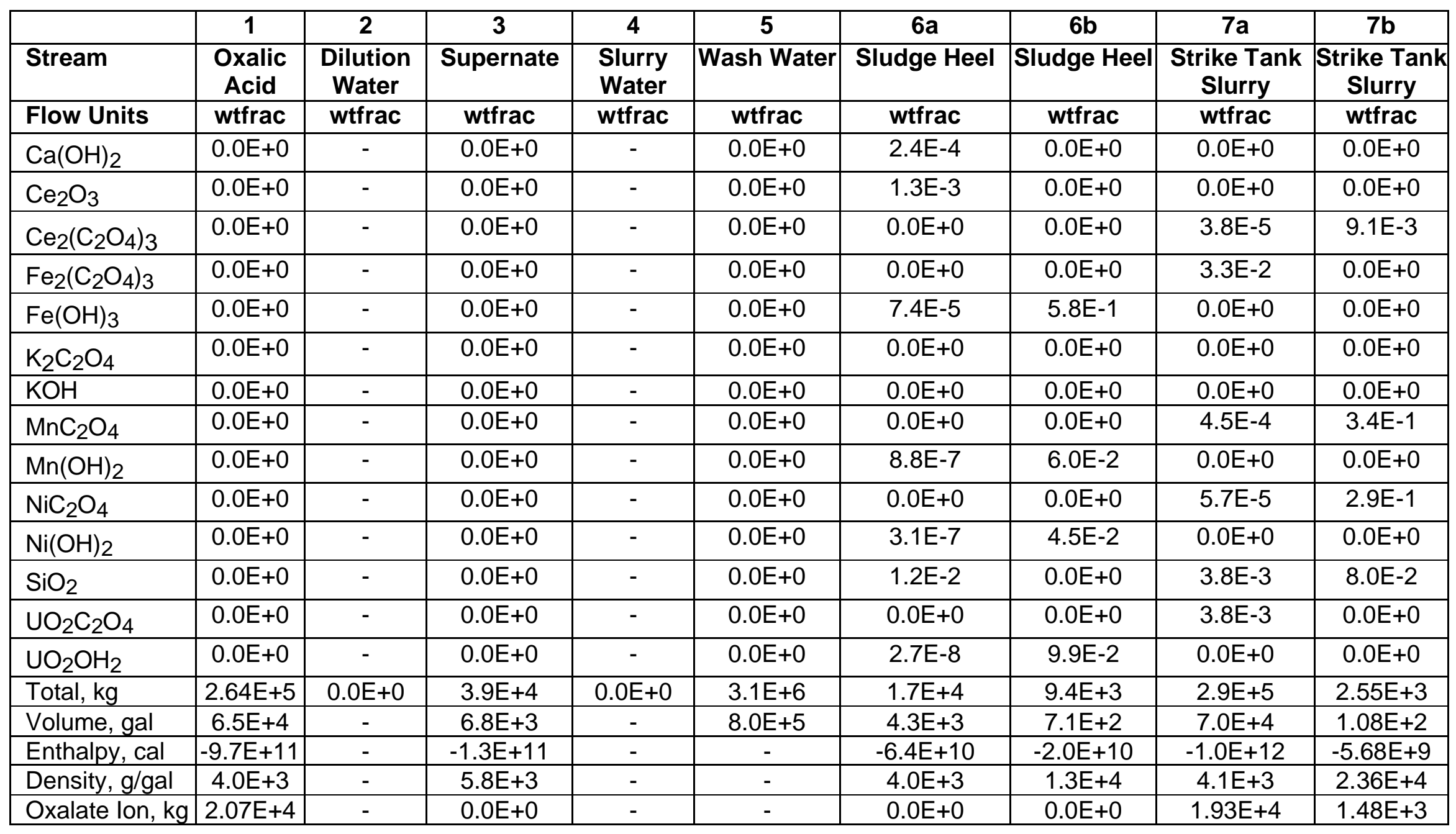


Table A5-1 Tank 8 Purex Dissolution Material Balance, pH Adj. w/ NaOH (Case \#1 - Sheet 3 of 4)

\begin{tabular}{|c|c|c|c|c|c|c|c|c|c|c|}
\hline & 8 & 9 & 10 & 11 & 12 & $13 a$ & $13 b$ & 14 & 15 & 16 \\
\hline Stream Name & \begin{tabular}{|c|} 
Adj Tank \\
Supernate
\end{tabular} & $\begin{array}{l}\text { Evap } \\
\text { Feed }\end{array}$ & $\begin{array}{l}\text { Evap } \\
\text { Conc }\end{array}$ & $\begin{array}{l}\text { Dissolution } \\
\text { Water }\end{array}$ & $\begin{array}{l}\text { Dissolved } \\
\text { Salt }\end{array}$ & $\begin{array}{l}\text { Adjust } \\
\text { Tank }\end{array}$ & $\begin{array}{l}\text { Adjust } \\
\text { Tank }\end{array}$ & $\begin{array}{l}\text { Washed } \\
\text { Sludge }\end{array}$ & $\begin{array}{c}\text { Decant } \\
\text { Wash Water }\end{array}$ & $\begin{array}{l}\text { Feed } \\
\text { Tank }\end{array}$ \\
\hline Phase & Aqueous & Aqueous & $\begin{array}{c}\text { Aqueou } \\
\mathrm{s}\end{array}$ & Aqueous - & - Aqueous & Aqueous & Solid & Slurry & Aqueous & Slurry \\
\hline Temp, ${ }^{\circ} \mathrm{C}$ & 30 & 30 & 30 & 30 & 30 & 30 & 30 & 30 & 30 & 30 \\
\hline Flow Units & wtfrac & Wtfrac & wtfrac & wtfrac & wtfrac & wtfrac & wtfrac & wtfrac & wtfrac & wtfrac \\
\hline $\mathrm{H}_{2} \mathrm{O}$ & $9.61 \mathrm{E}-1$ & - & - & 9.99E-1 & - & $9.61 \mathrm{E}-1$ & $0.00 \mathrm{E}+0$ & - & $8.09 \mathrm{E}-1$ & - \\
\hline $\mathrm{H}_{2} \mathrm{C}_{2} \mathrm{O}_{4}$ & $0.00 \mathrm{E}+0$ & - & - & $0.00 \mathrm{E}+0$ & - & $0.00 \mathrm{E}+0$ & $0.00 \mathrm{E}+0$ & - & $0.00 \mathrm{E}+0$ & - \\
\hline $\mathrm{HCl}$ & $0.00 \mathrm{E}+0$ & - & - & $0.00 \mathrm{E}+0$ & - & $0.00 \mathrm{E}+0$ & $0.00 \mathrm{E}+0$ & - & $0.00 \mathrm{E}+0$ & - \\
\hline $\mathrm{HNO}_{3}$ & $0.00 \mathrm{E}+0$ & - & - & $0.00 \mathrm{E}+0$ & - & $0.00 \mathrm{E}+0$ & $0.00 \mathrm{E}+0$ & - & $0.00 \mathrm{E}+0$ & - \\
\hline $\mathrm{Na}_{2} \mathrm{CO}_{3}$ & 2.07E-3 & - & - & $0.00 \mathrm{E}+0$ & - & $2.07 E-3$ & $0.00 \mathrm{E}+0$ & - & $1.01 \mathrm{E}-2$ & - \\
\hline $\mathrm{NaCl}$ & $7.12 \mathrm{E}-4$ & - & - & $0.00 \mathrm{E}+0$ & - & $7.11 \mathrm{E}-4$ & $0.00 \mathrm{E}+0$ & - & $2.40 \mathrm{E}-4$ & - \\
\hline $\mathrm{NaNO}_{2}$ & $0.00 \mathrm{E}+0$ & - & - & $7.50 \mathrm{E}-4$ & - & $0.00 \mathrm{E}+0$ & $0.00 \mathrm{E}+0$ & - & 7.64E-2 & - \\
\hline $\mathrm{NaNO}_{3}$ & $6.23 E-4$ & - & - & $0.00 \mathrm{E}+0$ & - & $6.22 E-4$ & $0.00 \mathrm{E}+0$ & - & 6.98E-2 & - \\
\hline $\mathrm{NaOH}$ & $4.55 E-3$ & - & - & $3.95 \mathrm{E}-4$ & - & $4.99 \mathrm{E}-3$ & $0.00 \mathrm{E}+0$ & - & $1.76 \mathrm{E}-2$ & - \\
\hline $\mathrm{Na}_{2} \mathrm{SO}_{4}$ & $0.00 \mathrm{E}+0$ & - & - & $0.00 \mathrm{E}+0$ & - & $0.00 \mathrm{E}+0$ & $0.00 \mathrm{E}+0$ & - & $3.03 E-3$ & - \\
\hline $\mathrm{Na}_{2} \mathrm{C}_{2} \mathrm{O}_{4}$ & $2.90 E-2$ & $1.0 \mathrm{E}+0$ & $1.0 \mathrm{E}+0$ & $0.00 \mathrm{E}+0$ & $0.00 \mathrm{E}+0$ & $2.90 \mathrm{E}-2$ & $7.01 \mathrm{E}-1$ & $5.51 \mathrm{E}-2$ & 5.79E-3 & $1.00 \mathrm{E}+0$ \\
\hline $\mathrm{Al}(\mathrm{OH})_{3}$ & $0.00 \mathrm{E}+0$ & - & - & $0.00 \mathrm{E}+0$ & - & $0.00 \mathrm{E}+0$ & $4.15 \mathrm{E}-2$ & - & $0.00 \mathrm{E}+0$ & - \\
\hline $\mathrm{AlOOH}$ & $0.00 \mathrm{E}+0$ & - & - & $0.00 \mathrm{E}+0$ & - & $0.00 \mathrm{E}+0$ & $0.00 \mathrm{E}+0$ & - & $0.00 \mathrm{E}+0$ & - \\
\hline $\mathrm{NaAlO}_{2}$ & $6.55 \mathrm{E}-4$ & - & - & $0.00 \mathrm{E}+0$ & - & $6.55 \mathrm{E}-4$ & $0.00 \mathrm{E}+0$ & - & $7.60 \mathrm{E}-3$ & - \\
\hline
\end{tabular}


Table A5-1 Tank 8 Purex Dissolution Material Balance, pH Adj. w/ NaOH (Case \#1 - Sheet 4 of 4)

\begin{tabular}{|c|c|c|c|c|c|c|c|c|c|c|}
\hline & \begin{tabular}{|l|}
8 \\
\end{tabular} & 9 & 10 & 11 & \begin{tabular}{|l|}
12 \\
\end{tabular} & $13 a$ & $13 b$ & 14 & 15 & 16 \\
\hline Stream Name & \begin{tabular}{|c|} 
Adj Tank \\
Supernate
\end{tabular} & $\begin{array}{l}\text { Evap } \\
\text { Feed }\end{array}$ & $\begin{array}{l}\text { Evap } \\
\text { Conc }\end{array}$ & $\begin{array}{l}\text { Dissolution } \\
\text { Water }\end{array}$ & \begin{tabular}{|c|} 
Dissolved \\
Salt
\end{tabular} & $\begin{array}{l}\text { Adj Tank } \\
\text { Solids }\end{array}$ & $\begin{array}{l}\text { Adj Tank } \\
\text { Solids }\end{array}$ & $\begin{array}{l}\text { Wash } \\
\text { Sludge }\end{array}$ & $\begin{array}{l}\text { Decant } \\
\text { Water }\end{array}$ & $\begin{array}{l}\text { Feed Tank } \\
\text { Sludge }\end{array}$ \\
\hline Flow Units & wtfrac & Wtfrac & wtfrac & wtfrac & wtfrac & wtfrac & wtfrac & wtfrac & wtfrac & wtfrac \\
\hline $\mathrm{CaC}_{2} \mathrm{O}_{4}$ & 7.62E-7 & - & - & $0.00 \mathrm{E}+0$ & - & $7.61 \mathrm{E}-7$ & $2.38 \mathrm{E}-2$ & - & $0.00 \mathrm{E}+0$ & - \\
\hline $\mathrm{CaCO}_{3}$ & $0.00 \mathrm{E}+0$ & - & - & $0.00 \mathrm{E}+0$ & - & $0.00 \mathrm{E}+0$ & $0.00 \mathrm{E}+0$ & - & $0.00 \mathrm{E}+0$ & - \\
\hline $\mathrm{Ca}(\mathrm{OH})_{2}$ & $0.00 \mathrm{E}+0$ & - & - & $0.00 \mathrm{E}+0$ & - & $0.00 \mathrm{E}+0$ & $0.00 \mathrm{E}+0$ & - & $0.00 \mathrm{E}+0$ & - \\
\hline $\mathrm{Ce}_{2} \mathrm{O}_{3}$ & $7.64 \mathrm{E}-5$ & - & - & $0.00 \mathrm{E}+0$ & - & $7.63 \mathrm{E}-5$ & $0.00 \mathrm{E}+0$ & - & $0.00 \mathrm{E}+0$ & - \\
\hline $\mathrm{Ce}_{2}\left(\mathrm{C}_{2} \mathrm{O}_{4}\right)_{3}$ & $0.00 \mathrm{E}+0$ & - & - & $0.00 \mathrm{E}+0$ & - & $0.00 \mathrm{E}+0$ & $0.00 \mathrm{E}+0$ & - & $0.00 \mathrm{E}+0$ & - \\
\hline $\mathrm{Fe}_{2}\left(\mathrm{C}_{2} \mathrm{O}_{4}\right)_{3}$ & $2.55 \mathrm{E}-5$ & - & - & $0.00 \mathrm{E}+0$ & - & $2.54 \mathrm{E}-5$ & $0.00 \mathrm{E}+0$ & - & $0.00 \mathrm{E}+0$ & - \\
\hline $\mathrm{Fe}(\mathrm{OH})_{3}$ & $0.00 \mathrm{E}+0$ & - & - & $0.00 \mathrm{E}+0$ & - & $0.00 \mathrm{E}+0$ & $1.74 \mathrm{E}-1$ & - & $0.00 \mathrm{E}+0$ & - \\
\hline $\mathrm{K}_{2} \mathrm{C}_{2} \mathrm{O}_{4}$ & $0.00 \mathrm{E}+0$ & - & - & $0.00 \mathrm{E}+0$ & - & $0.00 \mathrm{E}+0$ & $0.00 \mathrm{E}+0$ & - & $0.00 \mathrm{E}+0$ & - \\
\hline $\mathrm{KOH}$ & $0.00 \mathrm{E}+0$ & - & - & $0.00 \mathrm{E}+0$ & - & $0.00 \mathrm{E}+0$ & $0.00 \mathrm{E}+0$ & - & $0.00 \mathrm{E}+0$ & - \\
\hline $\mathrm{MnC}_{2} \mathrm{O}_{4}$ & $2.78 \mathrm{E}-6$ & - & - & $0.00 \mathrm{E}+0$ & - & $2.78 \mathrm{E}-6$ & $0.00 \mathrm{E}+0$ & - & $0.00 \mathrm{E}+0$ & - \\
\hline $\mathrm{Mn}(\mathrm{OH})_{2}$ & $0.00 \mathrm{E}+0$ & - & - & $0.00 \mathrm{E}+0$ & - & $0.00 \mathrm{E}+0$ & $1.78 \mathrm{E}-2$ & - & $0.00 \mathrm{E}+0$ & - \\
\hline $\mathrm{NiC}_{2} \mathrm{O}_{4}$ & $9.54 \mathrm{E}-8$ & - & - & $0.00 \mathrm{E}+0$ & - & 9.53E-08 & $0.00 \mathrm{E}+0$ & - & $0.00 \mathrm{E}+0$ & - \\
\hline $\mathrm{Ni}(\mathrm{OH})_{2}$ & $0.00 \mathrm{E}+0$ & - & - & $0.00 \mathrm{E}+0$ & - & $0.00 \mathrm{E}+0$ & $1.36 \mathrm{E}-2$ & - & $0.00 \mathrm{E}+0$ & - \\
\hline $\mathrm{SiO}_{2}$ & $7.12 \mathrm{E}-4$ & - & - & $0.00 \mathrm{E}+0$ & - & 7.11E-4 & $0.00 \mathrm{E}+0$ & - & $0.00 \mathrm{E}+0$ & - \\
\hline $\mathrm{UO}_{2} \mathrm{C}_{2} \mathrm{O}_{4}$ & $1.07 \mathrm{E}-4$ & - & - & $0.00 \mathrm{E}+0$ & - & $1.07 \mathrm{E}-4$ & $0.00 \mathrm{E}+0$ & - & $0.00 \mathrm{E}+0$ & - \\
\hline $\mathrm{UO}_{2} \mathrm{OH}_{2}$ & $0.00 \mathrm{E}+0$ & - & - & $0.00 \mathrm{E}+0$ & - & $0.00 \mathrm{E}+0$ & $2.88 \mathrm{E}-0$ & - & $0.00 \mathrm{E}+0$ & - \\
\hline Total, kg & $1.41 \mathrm{E}+5$ & $1.23 E+3$ & $1.23 E+3$ & $8.39 \mathrm{E}+6$ & - & $1.57 E+5$ & $3.15 E+4$ & $4.01 E+5$ & $3.77 E+5$ & $5.06 \mathrm{E}+3$ \\
\hline Volume, gal & $3.62 \mathrm{E}+4$ & - & - & $2.20 \mathrm{E}+6$ & $3.20 \mathrm{E}+6$ & $4.02 \mathrm{E}+4$ & $7.38 \mathrm{E}+2$ & $5.53 \mathrm{E}+5$ & $1.38 \mathrm{E}+6$ & - \\
\hline Enthalpy, cal & $-5.28 E+11$ & - & - & - & - & $-5.87 E+11$ & $-7.23 E+10$ & - & - & - \\
\hline Density, g/gal & $3.91 \mathrm{E}+3$ & - & - & $3.82 E+3$ & - & $3.91 \mathrm{E}+3$ & $4.26 \mathrm{E}+4$ & - & - & - \\
\hline Oxalate ion, $\mathrm{kg}$ & $2.70 \mathrm{E}+3$ & $8.08 E+2$ & $8.08 \mathrm{E}+2$ & - & $0.00 \mathrm{E}+0$ & $3.01 E+3$ & $1.50 \mathrm{E}+4$ & $1.61 \mathrm{E}+4$ & $1.44 \mathrm{E}+3$ & $3.32 E+3$ \\
\hline
\end{tabular}


Table A5-2 Tank 8 Purex Dissolution Material Balance, pH Adj. w/ Supernate (Case \#2 - Sheet 1 of 4)

\begin{tabular}{|c|c|c|c|c|c|c|c|c|c|}
\hline & 1 & 2 & 3 & 4 & 5 & $6 a$ & $6 b$ & $7 a$ & $7 b$ \\
\hline $\begin{array}{l}\text { Stream } \\
\text { Name }\end{array}$ & $\begin{array}{c}\text { Oxalic } \\
\text { Acid }\end{array}$ & $\begin{array}{l}\text { Dilution } \\
\text { Water }\end{array}$ & $\begin{array}{l}\text { pH Adjust } \\
\text { Solution }\end{array}$ & $\begin{array}{l}\text { Slurry } \\
\text { Water }\end{array}$ & Wash Water & $\begin{array}{c}\text { Sludge } \\
\text { Heel }\end{array}$ & $\begin{array}{c}\text { Sludge } \\
\text { Heel }\end{array}$ & $\begin{array}{c}\text { Dissolv. } \\
\text { Heel }\end{array}$ & $\begin{array}{c}\text { Dissolv. } \\
\text { Heel }\end{array}$ \\
\hline Phase & Aqueous & Aqueous & Aqueous & Aqueous & Aqueous & Aqueous & Solid & Aqueous & Solid \\
\hline Temp, ${ }^{\circ} \mathrm{C}$ & 30 & - & 30 & - & - & 30 & 30 & 30 & 30 \\
\hline $\mathrm{pH}$ & 0.7 & - & - & - & - & 13.4 & - & 0.7 & - \\
\hline Flow Units & wtfrac & Wtfrac & wtfrac & wtfrac & wtfrac & wtfrac & wtfrac & wtfrac & wtfrac \\
\hline $\mathrm{H}_{2} \mathrm{O}$ & $9.20 \mathrm{E}-1$ & - & $6.79 \mathrm{E}-1$ & - & $9.76 \mathrm{E}-1$ & $9.25 \mathrm{E}-1$ & $0.0 \mathrm{E}+0$ & $9.1 \mathrm{E}-1$ & $0.0 \mathrm{E}+0$ \\
\hline $\mathrm{H}_{2} \mathrm{C}_{2} \mathrm{O}_{4}$ & 8.00E-2 & - & $0.0 \mathrm{E}+0$ & - & $0.0 \mathrm{E}+0$ & $0.0 \mathrm{E}+0$ & $0.0 \mathrm{E}+0$ & $4.0 \mathrm{E}-2$ & $0.0 \mathrm{E}+0$ \\
\hline $\mathrm{HCl}$ & $0.0 \mathrm{E}+0$ & - & $0.0 \mathrm{E}+0$ & - & $0.0 \mathrm{E}+0$ & $0.0 \mathrm{E}+0$ & $0.0 \mathrm{E}+0$ & $4.6 \mathrm{E}-4$ & $0.0 \mathrm{E}+0$ \\
\hline $\mathrm{HNO}_{3}$ & $0.0 \mathrm{E}+0$ & - & $0.0 \mathrm{E}+0$ & - & $0.0 \mathrm{E}+0$ & $0.0 \mathrm{E}+0$ & $0.0 \mathrm{E}+0$ & $4.8 \mathrm{E}-4$ & $0.0 \mathrm{E}+0$ \\
\hline $\mathrm{Na}_{2} \mathrm{CO}_{3}$ & $0.0 \mathrm{E}+0$ & - & $1.42 \mathrm{E}-2$ & - & $0.0 \mathrm{E}+0$ & $3.44 \mathrm{E}-4$ & $0.0 \mathrm{E}+0$ & $2.1 \mathrm{E}-3$ & $0.0 \mathrm{E}+0$ \\
\hline $\mathrm{NaCl}$ & $0.0 \mathrm{E}+0$ & - & $0.0 \mathrm{E}+0$ & - & $0.0 \mathrm{E}+0$ & $1.23 \mathrm{E}-2$ & $0.0 \mathrm{E}+0$ & $0.0 \mathrm{E}+0$ & $0.0 \mathrm{E}+0$ \\
\hline $\mathrm{NaNO}_{2}$ & $0.0 \mathrm{E}+0$ & - & $3.11 \mathrm{E}-2$ & - & $2.41 \mathrm{E}-2$ & $0.0 \mathrm{E}+0$ & $0.0 \mathrm{E}+0$ & $0.0 \mathrm{E}+0$ & $0.0 \mathrm{E}+0$ \\
\hline $\mathrm{NaNO}_{3}$ & $0.0 \mathrm{E}+0$ & - & $1.59 \mathrm{E}-1$ & - & $0.0 \mathrm{E}+0$ & $1.08 \mathrm{E}-2$ & $0.0 \mathrm{E}+0$ & $0.0 \mathrm{E}+0$ & $0.0 \mathrm{E}+0$ \\
\hline $\mathrm{NaOH}$ & $0.0 \mathrm{E}+0$ & - & 7.62E-2 & - & $0.0 \mathrm{E}+0$ & $3.44 \mathrm{E}-2$ & $0.0 \mathrm{E}+0$ & $0.0 \mathrm{E}+0$ & $0.0 \mathrm{E}+0$ \\
\hline $\mathrm{Na}_{2} \mathrm{SO}_{4}$ & $0.0 \mathrm{E}+0$ & - & $1.77 \mathrm{E}-2$ & - & $0.0 \mathrm{E}+0$ & $0.0 \mathrm{E}+0$ & $0.0 \mathrm{E}+0$ & $0.0 \mathrm{E}+0$ & $0.0 \mathrm{E}+0$ \\
\hline $\mathrm{Na}_{2} \mathrm{C}_{2} \mathrm{O}_{4}$ & $0.0 \mathrm{E}+0$ & - & $0.0 \mathrm{E}+0$ & - & $0.0 \mathrm{E}+0$ & $0.0 \mathrm{E}+0$ & $0.0 \mathrm{E}+0$ & $4.42 E-3$ & $0.0 \mathrm{E}+0$ \\
\hline $\mathrm{Al}(\mathrm{OH})_{3}$ & $0.0 \mathrm{E}+0$ & - & $0.0 \mathrm{E}+0$ & - & $0.0 \mathrm{E}+0$ & $0.0 E+0$ & $1.53 \mathrm{E}-1$ & $0.0 \mathrm{E}+0$ & $0.0 \mathrm{E}+0$ \\
\hline $\mathrm{AlOOH}$ & $0.0 \mathrm{E}+0$ & - & $0.0 \mathrm{E}+0$ & - & $0.0 \mathrm{E}+0$ & $0.0 \mathrm{E}+0$ & $0.0 \mathrm{E}+0$ & $3.95 E-3$ & $0.0 \mathrm{E}+0$ \\
\hline $\mathrm{NaAlO}_{2}$ & $0.0 \mathrm{E}+0$ & - & 2.17E-2 & - & $0.0 \mathrm{E}+0$ & $3.29 E-3$ & $0.0 \mathrm{E}+0$ & $0.0 \mathrm{E}+0$ & $0.0 \mathrm{E}+0$ \\
\hline
\end{tabular}


Table A5-2 Tank 8 Purex Dissolution Material Balance, pH Adj. w/ Supernate (Case \#2 - Sheet 2 of 4)

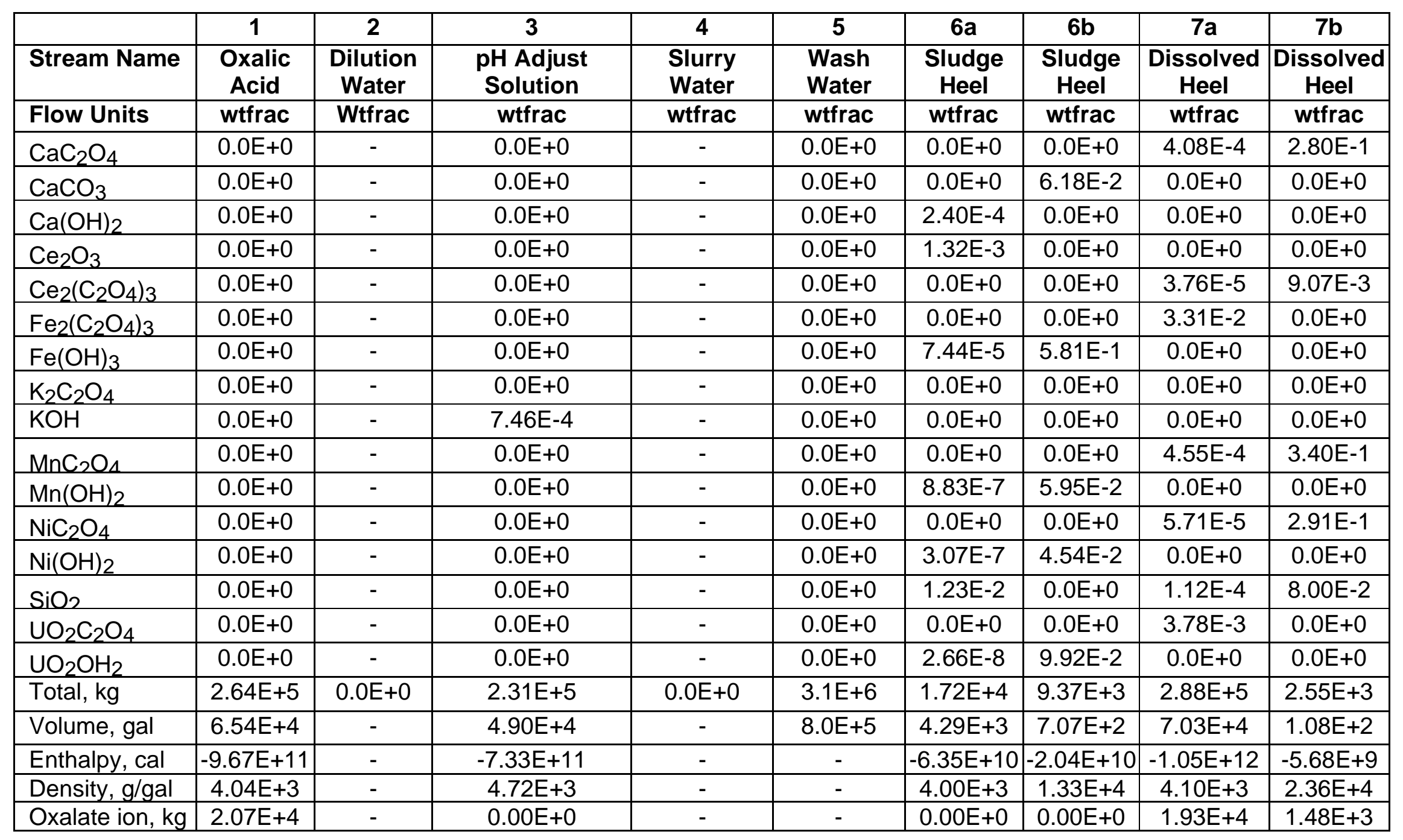


Table A5-2 Tank 8 Purex Dissolution Material Balance, pH Adj. w/ Supernate (Case \#2 - Sheet 3 of 4)

\begin{tabular}{|c|c|c|c|c|c|c|c|c|c|c|}
\hline & 8 & 9 & 10 & 11 & 12 & $13 a$ & $13 b$ & 14 & 15 & 16 \\
\hline Stream Name & \begin{tabular}{|c|} 
Adjust \\
Supernate
\end{tabular} & $\begin{array}{l}\text { Evap } \\
\text { Feed }\end{array}$ & $\begin{array}{l}\text { Evap } \\
\text { Conc }\end{array}$ & $\begin{array}{c}\text { Dissolution } \\
\text { Water }\end{array}$ & $\begin{array}{l}\text { Dissolved } \\
\text { Salt }\end{array}$ & $\begin{array}{l}\text { Solids } \\
\text { Slurry }\end{array}$ & $\begin{array}{l}\text { Solids } \\
\text { Slurry }\end{array}$ & $\begin{array}{l}\text { Washed } \\
\text { Sludge }\end{array}$ & $\begin{array}{l}\text { Decant } \\
\text { Water }\end{array}$ & $\begin{array}{l}\text { Feed Tank } \\
\text { Sludge }\end{array}$ \\
\hline Phase & Aqueous & Aqueous & Aqueous & Aqueous & Aqueous & Aqueous & Solid & Slurry & Aqueous & Slurry \\
\hline Temp, ${ }^{\circ} \mathrm{C}$ & 30 & 30 & 30 & 30 & 30 & 30 & 30 & 30 & 30 & 30 \\
\hline $\mathrm{pH}$ & 12.8 & - & - & 12 & - & 12.8 & - & - & - & - \\
\hline Flow Units & wtfrac & Wtfrac & wtfrac & wtfrac & wtfrac & wtfrac & wtfrac & wtfrac & wtfrac & wtfrac \\
\hline $\mathrm{H}_{2} \mathrm{O}$ & $8.78 \mathrm{E}-1$ & - & - & $1.0 \mathrm{E}+0$ & - & $8.71 \mathrm{E}-1$ & $0.0 \mathrm{E}+0$ & - & $8.08 \mathrm{E}-1$ & - \\
\hline $\mathrm{H}_{2} \mathrm{C}_{2} \mathrm{O}_{4}$ & $0.0 \mathrm{E}+0$ & - & - & $0.0 \mathrm{E}+0$ & - & $0.0 \mathrm{E}+0$ & $0.0 \mathrm{E}+0$ & - & $0.0 \mathrm{E}+0$ & - \\
\hline $\mathrm{HCl}$ & $0.0 \mathrm{E}+0$ & - & - & $0.0 \mathrm{E}+0$ & - & $0.0 \mathrm{E}+0$ & $0.0 \mathrm{E}+0$ & - & $0.0 \mathrm{E}+0$ & - \\
\hline $\mathrm{HNO}_{3}$ & $0.0 \mathrm{E}+0$ & - & - & $0.0 \mathrm{E}+0$ & - & $0.0 \mathrm{E}+0$ & $0.0 \mathrm{E}+0$ & - & $0.0 \mathrm{E}+0$ & - \\
\hline $\mathrm{Na}_{2} \mathrm{CO}_{3}$ & $8.11 \mathrm{E}-3$ & - & - & $0.0 \mathrm{E}+0$ & - & 8.07E-3 & $0.0 \mathrm{E}+0$ & - & $1.00 \mathrm{E}-2$ & - \\
\hline $\mathrm{NaCl}$ & $4.42 E-4$ & - & - & $0.0 \mathrm{E}+0$ & - & 4.39E-4 & $0.0 \mathrm{E}+0$ & - & $2.40 \mathrm{E}-4$ & - \\
\hline $\mathrm{NaNO}_{2}$ & $1.50 \mathrm{E}-2$ & - & - & $7.50 \mathrm{E}-4$ & - & $1.49 \mathrm{E}-2$ & $0.0 \mathrm{E}+0$ & - & $7.63 E-2$ & - \\
\hline $\mathrm{NaNO}_{3}$ & 7.69E-2 & - & - & $0.0 \mathrm{E}+0$ & - & $7.65 E-2$ & $0.0 \mathrm{E}+0$ & - & 6.97E-2 & - \\
\hline $\mathrm{NaOH}$ & $4.18 \mathrm{E}-3$ & - & - & $3.95 \mathrm{E}-4$ & - & 1.16E-2 & $0.0 \mathrm{E}+0$ & - & $1.76 \mathrm{E}-2$ & - \\
\hline $\mathrm{Na}_{2} \mathrm{SO}_{4}$ & $8.52 \mathrm{E}-3$ & - & - & $0.0 \mathrm{E}+0$ & - & $8.48 \mathrm{E}-3$ & $0.0 \mathrm{E}+0$ & - & $3.02 E-3$ & - \\
\hline $\mathrm{Na}_{2} \mathrm{C}_{2} \mathrm{O}_{4}$ & $4.95 \mathrm{E}-3$ & $1.0 \mathrm{E}+0$ & $1.0 \mathrm{E}+0$ & $0.0 \mathrm{E}+0$ & $0.0 \mathrm{E}+0$ & $4.93 \mathrm{E}-3$ & $6.79 \mathrm{E}-1$ & $6.31 \mathrm{E}-2$ & $7.66 \mathrm{E}-3$ & $1.0 \mathrm{E}+0$ \\
\hline $\mathrm{Al}(\mathrm{OH})_{3}$ & $0.0 \mathrm{E}+0$ & - & - & $0.0 \mathrm{E}+0$ & - & $0.0 \mathrm{E}+0$ & $1.45 \mathrm{E}-1$ & - & $0.0 \mathrm{E}+0$ & - \\
\hline $\mathrm{AlOOH}$ & $0.0 \mathrm{E}+0$ & - & - & $0.0 \mathrm{E}+0$ & - & $0.0 \mathrm{E}+0$ & $0.0 \mathrm{E}+0$ & - & $0.0 \mathrm{E}+0$ & - \\
\hline $\mathrm{NaAlO}_{2}$ & $7.74 \mathrm{E}-4$ & - & - & $0.0 \mathrm{E}+0$ & - & $7.70 \mathrm{E}-4$ & $0.0 \mathrm{E}+0$ & - & $7.59 \mathrm{E}-3$ & - \\
\hline $\mathrm{CaC}_{2} \mathrm{O}_{4}$ & $2.15 \mathrm{E}-6$ & - & - & $0.0 \mathrm{E}+0$ & - & $2.14 \mathrm{E}-6$ & $1.83 \mathrm{E}-2$ & $1.83 \mathrm{E}-3$ & $1.00 \mathrm{E}-6$ & - \\
\hline $\mathrm{CaCO}_{3}$ & $0.0 \mathrm{E}+0$ & - & - & $0.0 \mathrm{E}+0$ & - & $0.0 \mathrm{E}+0$ & $0.0 \mathrm{E}+0$ & - & $0.0 \mathrm{E}+0$ & - \\
\hline
\end{tabular}


Table A5-2 Tank 8 Purex Dissolution. Material Balance, pH Adj. w/ Supernate (Case \#2 - Sheet 4 of 4)

\begin{tabular}{|c|c|c|c|c|c|c|c|c|c|c|}
\hline & 8 & 9 & 10 & 11 & 12 & $13 a$ & $13 b$ & 14 & 15 & 16 \\
\hline Stream Name & $\begin{array}{c}\text { Adjust } \\
\text { Supernate }\end{array}$ & $\begin{array}{l}\text { Evap } \\
\text { Feed }\end{array}$ & $\begin{array}{l}\text { Evap } \\
\text { Conc }\end{array}$ & $\begin{array}{c}\text { Dissolutio } \\
\text { n Water }\end{array}$ & \begin{tabular}{|c|} 
Dissolved \\
Salt
\end{tabular} & $\begin{array}{l}\text { Solids } \\
\text { Slurry } \\
\end{array}$ & $\begin{array}{l}\text { Solids } \\
\text { Slurry }\end{array}$ & $\begin{array}{l}\text { Washed } \\
\text { Sludge }\end{array}$ & $\begin{array}{l}\text { Decant } \\
\text { Water }\end{array}$ & $\begin{array}{c}\text { Feed Tank } \\
\text { Sludge }\end{array}$ \\
\hline Flow Units & wtfrac & wtfrac & wtfrac & wtfrac & wtfrac & wtfrac & wtfrac & wtfrac & wtfrac & wtfrac \\
\hline $\mathrm{Ca}(\mathrm{OH})_{2}$ & $0.0 \mathrm{E}+0$ & - & - & $0.0 \mathrm{E}+0$ & - & $0.0 \mathrm{E}+0$ & $0.0 \mathrm{E}+0$ & - & $0.0 \mathrm{E}+0$ & - \\
\hline $\mathrm{Ce}_{2} \mathrm{O}_{3}$ & $4.74 \mathrm{E}-5$ & - & - & $0.0 \mathrm{E}+0$ & - & $4.72 \mathrm{E}-5$ & $0.0 \mathrm{E}+0$ & $3.17 \mathrm{E}-6$ & $2.21 \mathrm{E}-5$ & - \\
\hline $\mathrm{CeO}\left(\mathrm{C}_{2} \mathrm{O}_{1}\right)_{2}$ & $0.0 \mathrm{E}+0$ & - & - & $0.0 \mathrm{E}+0$ & - & $0.0 \mathrm{E}+0$ & $0.0 \mathrm{E}+0$ & - & $0.0 \mathrm{E}+0$ & - \\
\hline $\mathrm{Fe}_{2}\left(\mathrm{C}_{2} \mathrm{O}_{4}\right)_{3}$ & $3.17 \mathrm{E}-5$ & - & - & $0.0 \mathrm{E}+0$ & - & $3.16 \mathrm{E}-5$ & $0.0 \mathrm{E}+0$ & $2.12 \mathrm{E}-6$ & $1.48 \mathrm{E}-5$ & - \\
\hline $\mathrm{Fe}(\mathrm{OH})_{3}$ & $0.0 \mathrm{E}+0$ & - & - & $0.0 \mathrm{E}+0$ & - & $0.0 \mathrm{E}+0$ & $1.34 \mathrm{E}-1$ & - & $0.0 \mathrm{E}+0$ & - \\
\hline $\mathrm{K}_{2} \mathrm{C}_{2} \mathrm{O}_{4}$ & $5.31 \mathrm{E}-4$ & - & - & $0.0 \mathrm{E}+0$ & - & $5.28 \mathrm{E}-4$ & $0.0 \mathrm{E}+0$ & $3.55 E-5$ & $2.47 \mathrm{E}-4$ & - \\
\hline $\mathrm{KOH}$ & $0.0 \mathrm{E}+0$ & - & - & $0.0 \mathrm{E}+0$ & - & $0.0 \mathrm{E}+0$ & $0.0 \mathrm{E}+0$ & - & $0.0 \mathrm{E}+0$ & - \\
\hline $\mathrm{MnC}_{2} \mathrm{O}_{4}$ & $1.98 \mathrm{E}-7$ & - & - & $0.0 \mathrm{E}+0$ & - & $1.97 \mathrm{E}-7$ & $0.0 \mathrm{E}+0$ & $1.32 \mathrm{E}-8$ & $9.21 \mathrm{E}-8$ & - \\
\hline $\mathrm{Mn}(\mathrm{OH})_{2}$ & $0.0 \mathrm{E}+0$ & - & - & $0.0 \mathrm{E}+0$ & - & $0.0 \mathrm{E}+0$ & 1.37E-02 & - & $0.0 \mathrm{E}+0$ & - \\
\hline $\mathrm{NiC}_{2} \mathrm{O}_{4}$ & $0.0 \mathrm{E}+0$ & - & - & $0.0 \mathrm{E}+0$ & - & $1.18 \mathrm{E}-7$ & $0.0 \mathrm{E}+0$ & $7.92 \mathrm{E}-9$ & $5.51 \mathrm{E}-8$ & - \\
\hline $\mathrm{Ni}(\mathrm{OH})_{2}$ & $1.18 \mathrm{E}-7$ & - & - & $0.0 \mathrm{E}+0$ & - & $0.0 \mathrm{E}+0$ & $0.0 \mathrm{E}+0$ & - & $0.0 \mathrm{E}+0$ & - \\
\hline $\mathrm{SiO}_{2}$ & $4.42 \mathrm{E}-4$ & - & - & $0.0 \mathrm{E}+0$ & - & $4.39 \mathrm{E}-4$ & $1.04 \mathrm{E}-2$ & - & $0.0 \mathrm{E}+0$ & - \\
\hline $\mathrm{UO}_{2} \mathrm{C}_{2} \mathrm{O}_{4}$ & $2.28 E-3$ & - & - & $0.0 \mathrm{E}+0$ & - & $2.26 \mathrm{E}-3$ & $0.0 \mathrm{E}+0$ & $1.52 \mathrm{E}-4$ & $1.06 \mathrm{E}-3$ & - \\
\hline $\mathrm{UO}_{2}(\mathrm{OH})_{2}$ & $0.0 \mathrm{E}+0$ & - & - & $0.0 \mathrm{E}+0$ & - & $0.0 \mathrm{E}+0$ & $0.0 \mathrm{E}+0$ & - & $0.0 \mathrm{E}+0$ & - \\
\hline $\mathrm{ThO}_{2}$ & $0.0 \mathrm{E}+0$ & - & - & $0.0 \mathrm{E}+0$ & - & $0.0 \mathrm{E}+0$ & $0.0 \mathrm{E}+0$ & - & $0.0 \mathrm{E}+0$ & - \\
\hline $\mathrm{HgO}$ & $0.0 \mathrm{E}+0$ & - & - & $0.0 \mathrm{E}+0$ & - & $0.0 \mathrm{E}+0$ & $0.0 \mathrm{E}+0$ & - & $0.0 \mathrm{E}+0$ & - \\
\hline Total, kg & $2.77 \mathrm{E}+5$ & $1.25 \mathrm{E}+3$ & $1.25 \mathrm{E}+3$ & $8.39 E+6$ & - & $2.04 \mathrm{E}+5$ & $4.08 \mathrm{E}+4$ & $4.10 \mathrm{E}+5$ & $3.77 \mathrm{E}+5$ & $3.01 \mathrm{E}+3$ \\
\hline Volume, gal & $6.74 \mathrm{E}+4$ & - & - & $2.20 \mathrm{E}+6$ & $3.20 \mathrm{E}+6$ & $4.96 \mathrm{E}+4$ & $1.24 \mathrm{E}+3$ & $5.5 \mathrm{E}+5$ & $1.38 \mathrm{E}+6$ & - \\
\hline Enthalpy, cal & $-9.73 E+11$ & - & - & - & - & $-7.17 \mathrm{E}+11$ & $-1.03 E+11$ & - & - & - \\
\hline Density, g/gal & $4.11 \mathrm{E}+3$ & - & - & $3.82 E+3$ & - & $4.11 E+3$ & $3.30 \mathrm{E}+4$ & - & - & - \\
\hline Oxalate lon, $\mathrm{kg}$ & $1.14 \mathrm{E}+3$ & $8.21 E+2$ & $8.21 E+2$ & - & $0.0 \mathrm{E}+0$ & $8.37 E+2$ & $1.87 \mathrm{E}+4$ & $1.70 \mathrm{E}+4$ & $2.05 \mathrm{E}+3$ & $1.98 \mathrm{E}+3$ \\
\hline
\end{tabular}


Table A5-3 Tank 11 HM Dissolution. Material Balance, pH Adj. w/ NaOH (Case \#3 - Sheet 1 of 4)

\begin{tabular}{|c|c|c|c|c|c|c|c|c|c|}
\hline & 1 & 2 & 3 & 4 & 5 & $6 \mathbf{a}$ & $6 b$ & $7 a$ & $7 b$ \\
\hline Stream Name & $\begin{array}{l}\text { Oxalic } \\
\text { Acid }\end{array}$ & $\begin{array}{c}\text { Dilution } \\
\text { Water }\end{array}$ & Supernate & $\begin{array}{l}\text { Slurry } \\
\text { Water }\end{array}$ & $\begin{array}{l}\text { Wash } \\
\text { Water }\end{array}$ & $\begin{array}{c}\text { Sludge } \\
\text { Heel }\end{array}$ & $\begin{array}{c}\text { Sludge } \\
\text { Heel }\end{array}$ & \begin{tabular}{|c|} 
Treatment Tank \\
Slurry
\end{tabular} & $\begin{array}{c}\text { Treatment Tank } \\
\text { Slurry }\end{array}$ \\
\hline Phase & Aqueous & Aqueous & Aqueous & Aqueous & Aqueous & Aqueous & Solid & Aqueous & Solid \\
\hline Temp, ${ }^{\circ} \mathrm{C}$ & 30 & & 30 & & & 30 & 30 & 30 & 30 \\
\hline $\mathrm{pH}$ & 0.74 & - & & - & & 11.59 & & 1.4 & \\
\hline Flow Units & wtfrac & wtfrac & wtfrac & wtfrac & wtfrac & wtfrac & wtfrac & wtfrac & wtfrac \\
\hline $\mathrm{H}_{2} \mathrm{O}$ & $9.2 \mathrm{E}-1$ & - & $5.0 \mathrm{E}-1$ & - & $9.76 \mathrm{E}-1$ & $9.40 \mathrm{E}-1$ & $0.0 \mathrm{E}+0$ & $9.10 \mathrm{E}-1$ & $0.0 \mathrm{E}+0$ \\
\hline $\mathrm{H}_{2} \mathrm{C}_{2} \mathrm{O}_{4}$ & $8.0 \mathrm{E}-2$ & - & $0.0 \mathrm{E}+0$ & - & $0.0 \mathrm{E}+0$ & $0.0 \mathrm{E}+0$ & $0.0 \mathrm{E}+0$ & $6.27 \mathrm{E}-2$ & $0.0 \mathrm{E}+0$ \\
\hline $\mathrm{HCl}$ & $0.0 \mathrm{E}+0$ & - & $0.0 \mathrm{E}+0$ & - & $0.0 \mathrm{E}+0$ & $0.0 \mathrm{E}+0$ & $0.0 \mathrm{E}+0$ & 8.66E-5 & $0.0 \mathrm{E}+0$ \\
\hline $\mathrm{HNO}_{3}$ & $0.0 \mathrm{E}+0$ & - & $0.0 \mathrm{E}+0$ & - & $0.0 \mathrm{E}+0$ & $0.0 \mathrm{E}+0$ & $0.0 \mathrm{E}+0$ & $5.14 \mathrm{E}-4$ & $0.0 \mathrm{E}+0$ \\
\hline $\mathrm{Na}_{2} \mathrm{CO}_{3}$ & $0.0 \mathrm{E}+0$ & - & $0.0 \mathrm{E}+0$ & - & $0.0 \mathrm{E}+0$ & $6.20 \mathrm{E}-5$ & $0.0 \mathrm{E}+0$ & $4.41 \mathrm{E}-4$ & $0.0 \mathrm{E}+0$ \\
\hline $\mathrm{NaCl}$ & $0.0 \mathrm{E}+0$ & - & $0.0 \mathrm{E}+0$ & - & $0.0 \mathrm{E}+0$ & $3.14 \mathrm{E}-3$ & $0.0 \mathrm{E}+0$ & $0.0 \mathrm{E}+0$ & $0.0 \mathrm{E}+0$ \\
\hline $\mathrm{NaNO}_{2}$ & $0.0 \mathrm{E}+0$ & - & $0.0 \mathrm{E}+0$ & - & $2.41 \mathrm{E}-2$ & $0.0 \mathrm{E}+0$ & $0.0 \mathrm{E}+0$ & $0.0 \mathrm{E}+0$ & $0.0 \mathrm{E}+0$ \\
\hline $\mathrm{NaNO}_{3}$ & $0.0 \mathrm{E}+0$ & - & $0.0 \mathrm{E}+0$ & - & $0.0 \mathrm{E}+0$ & $1.57 \mathrm{E}-2$ & $0.0 \mathrm{E}+0$ & $0.0 \mathrm{E}+0$ & $0.0 \mathrm{E}+0$ \\
\hline $\mathrm{NaOH}$ & $0.0 \mathrm{E}+0$ & - & $5.0 \mathrm{E}-1$ & - & $0.0 \mathrm{E}+0$ & 1.75E-2 & $0.0 \mathrm{E}+0$ & $0.0 \mathrm{E}+0$ & $0.0 \mathrm{E}+0$ \\
\hline $\mathrm{Na}_{2} \mathrm{SO}_{4}$ & $0.0 \mathrm{E}+0$ & - & $0.0 \mathrm{E}+0$ & - & $0.0 \mathrm{E}+0$ & $0.0 \mathrm{E}+0$ & $0.0 \mathrm{E}+0$ & $0.0 \mathrm{E}+0$ & $0.0 \mathrm{E}+0$ \\
\hline $\mathrm{Na}_{2} \mathrm{C}_{2} \mathrm{O}_{4}$ & $0.0 \mathrm{E}+0$ & - & $0.0 \mathrm{E}+0$ & - & $0.0 \mathrm{E}+0$ & $0.0 \mathrm{E}+0$ & $0.0 \mathrm{E}+0$ & $1.75 \mathrm{E}-3$ & $0.0 \mathrm{E}+0$ \\
\hline $\mathrm{Al}(\mathrm{OH})_{3}$ & $0.0 \mathrm{E}+0$ & - & $0.0 \mathrm{E}+0$ & - & $0.0 \mathrm{E}+0$ & $0.0 \mathrm{E}+0$ & $5.88 \mathrm{E}-1$ & $0.0 \mathrm{E}+0$ & $0.0 \mathrm{E}+0$ \\
\hline $\mathrm{AlOOH}$ & $0.0 \mathrm{E}+0$ & - & $0.0 \mathrm{E}+0$ & - & $0.0 \mathrm{E}+0$ & $0.0 \mathrm{E}+0$ & $0.0 \mathrm{E}+0$ & 1.13E-2 & $0.0 \mathrm{E}+0$ \\
\hline $\mathrm{NaAlO}_{2}$ & $0.0 \mathrm{E}+0$ & - & $0.0 \mathrm{E}+0$ & - & $0.0 \mathrm{E}+0$ & $4.38 \mathrm{E}-5$ & $0.0 \mathrm{E}+0$ & $0.0 \mathrm{E}+0$ & $0.0 \mathrm{E}+0$ \\
\hline $\mathrm{CaC}_{2} \mathrm{O}_{4}$ & $0.0 \mathrm{E}+0$ & - & $0.0 \mathrm{E}+0$ & - & $0.0 \mathrm{E}+0$ & 4.87E-5 & $0.0 \mathrm{E}+0$ & $3.96-5$ & $0.0 \mathrm{E}+0$ \\
\hline $\mathrm{CaCO}_{3}$ & $0.0 \mathrm{E}+0$ & - & $0.0 \mathrm{E}+0$ & - & $0.0 \mathrm{E}+0$ & $0.0 \mathrm{E}+0$ & $1.66 \mathrm{E}-2$ & $0.0 \mathrm{E}+0$ & $0.0 \mathrm{E}+0$ \\
\hline $\mathrm{Ca}(\mathrm{OH})_{2}$ & $0.0 \mathrm{E}+0$ & - & $0.0 \mathrm{E}+0$ & - & $0.0 \mathrm{E}+0$ & $4.3 \mathrm{E}-5$ & $0.0 \mathrm{E}+0$ & $0.0 \mathrm{E}+0$ & $0.0 \mathrm{E}+0$ \\
\hline
\end{tabular}


Table A5-3 Tank 11 HM Dissolution. Material Balance, pH Adj. w/ NAOH (Case \#3 - Sheet 2 of 4)

\begin{tabular}{|c|c|c|c|c|c|c|c|c|c|}
\hline & 1 & 2 & 3 & 4 & 5 & $6 a$ & $6 b$ & $7 a$ & $7 b$ \\
\hline Stream Name & $\begin{array}{c}\text { Oxalic } \\
\text { Acid }\end{array}$ & $\begin{array}{c}\text { Dilution } \\
\text { Water }\end{array}$ & Supernate & Slurry Water & Wash Water & $\begin{array}{c}\text { Sludge } \\
\text { Heel }\end{array}$ & $\begin{array}{c}\text { Sludge } \\
\text { Heel }\end{array}$ & $\begin{array}{l}\text { Treatmnt } \\
\text { Tk Slurry }\end{array}$ & $\begin{array}{l}\text { Treatment } \\
\text { Tk Slurry }\end{array}$ \\
\hline Flow Units & wtfrac & wtfrac & wtfrac & wtfrac & wtfrac & wtfrac & wtfrac & wtfrac & wtfrac \\
\hline $\mathrm{Ce}_{2} \mathrm{O}_{3}$ & $0.0 \mathrm{E}+0$ & - & $0.0 \mathrm{E}+0$ & - & $0.0 \mathrm{E}+0$ & $2.69 \mathrm{E}-3$ & $0.0 \mathrm{E}+0$ & $0.0 \mathrm{E}+0$ & $0.0 \mathrm{E}+0$ \\
\hline $\mathrm{Ce}_{2}\left(\mathrm{C}_{2} \mathrm{O}_{4}\right)_{3}$ & $0.0 \mathrm{E}+0$ & - & $0.0 \mathrm{E}+0$ & - & $0.0 \mathrm{E}+0$ & $0.0 \mathrm{E}+0$ & $0.0 \mathrm{E}+0$ & 6.07E-5 & $0.0 \mathrm{E}+0$ \\
\hline $\mathrm{Fe}_{2}\left(\mathrm{C}_{2} \mathrm{O}_{4}\right)_{3}$ & $0.0 \mathrm{E}+0$ & - & $0.0 \mathrm{E}+0$ & - & $0.0 \mathrm{E}+0$ & $0.0 \mathrm{E}+0$ & $0.0 \mathrm{E}+0$ & $1.11 \mathrm{E}-2$ & $0.0 \mathrm{E}+0$ \\
\hline $\mathrm{Fe}(\mathrm{OH})_{3}$ & $0.0 \mathrm{E}+0$ & - & $0.0 \mathrm{E}+0$ & - & $0.0 \mathrm{E}+0$ & 9.59E-7 & $2.54 \mathrm{E}-1$ & $0.0 \mathrm{E}+0$ & $0.0 \mathrm{E}+0$ \\
\hline $\mathrm{K}_{2} \mathrm{C}_{2} \mathrm{O}_{4}$ & $0.0 \mathrm{E}+0$ & - & $0.0 \mathrm{E}+0$ & - & $0.0 \mathrm{E}+0$ & $0.0 \mathrm{E}+0$ & $0.0 \mathrm{E}+0$ & $0.0 \mathrm{E}+0$ & $0.0 \mathrm{E}+0$ \\
\hline $\mathrm{KOH}$ & $0.0 \mathrm{E}+0$ & - & $0.0 \mathrm{E}+0$ & - & $0.0 \mathrm{E}+0$ & $0.0 \mathrm{E}+0$ & $0.0 \mathrm{E}+0$ & $0.0 \mathrm{E}+0$ & $0.0 \mathrm{E}+0$ \\
\hline $\mathrm{MnC}_{2} \mathrm{O}_{4}$ & $0.0 \mathrm{E}+0$ & - & $0.0 \mathrm{E}+0$ & - & $0.0 \mathrm{E}+0$ & $0.0 \mathrm{E}+0$ & $0.0 \mathrm{E}+0$ & $2.79 \mathrm{E}-4$ & $0.0 \mathrm{E}+0$ \\
\hline $\mathrm{Mn}(\mathrm{OH})_{2}$ & $0.0 \mathrm{E}+0$ & - & $0.0 \mathrm{E}+0$ & - & $0.0 \mathrm{E}+0$ & $1.03 \mathrm{E}-7$ & $5.85 \mathrm{E}-2$ & $0.0 \mathrm{E}+0$ & $0.0 \mathrm{E}+0$ \\
\hline $\mathrm{NiC}_{2} \mathrm{O}_{4}$ & $0.0 \mathrm{E}+0$ & - & $0.0 \mathrm{E}+0$ & - & $0.0 \mathrm{E}+0$ & $0.0 \mathrm{E}+0$ & $0.0 \mathrm{E}+0$ & $5.11 \mathrm{E}-5$ & $3.27 \mathrm{E}-1$ \\
\hline $\mathrm{Ni}(\mathrm{OH})_{2}$ & $0.0 \mathrm{E}+0$ & - & $0.0 \mathrm{E}+0$ & - & $0.0 \mathrm{E}+0$ & $4.53 \mathrm{E}-9$ & $1.11 \mathrm{E}-2$ & $0.0 \mathrm{E}+0$ & $0.0 \mathrm{E}+0$ \\
\hline $\mathrm{SiO}_{2}$ & $0.0 \mathrm{E}+0$ & - & $0.0 \mathrm{E}+0$ & - & $0.0 \mathrm{E}+0$ & $2.04 \mathrm{E}-2$ & $0.0 \mathrm{E}+0$ & $1.02 \mathrm{E}-4$ & $6.73 \mathrm{E}-1$ \\
\hline $\mathrm{UO}_{2} \mathrm{C}_{2} \mathrm{O}_{4}$ & $0.0 \mathrm{E}+0$ & - & $0.0 \mathrm{E}+0$ & - & $0.0 \mathrm{E}+0$ & $0.0 \mathrm{E}+0$ & $0.0 \mathrm{E}+0$ & 8.99E-4 & $0.0 \mathrm{E}+0$ \\
\hline $\mathrm{UO}_{2} \mathrm{OH}_{2}$ & $0.0 \mathrm{E}+0$ & - & $0.0 \mathrm{E}+0$ & - & $0.0 \mathrm{E}+0$ & 2.69E-7 & $3.06 \mathrm{E}-2$ & $0.0 \mathrm{E}+0$ & $0.0 \mathrm{E}+0$ \\
\hline $\mathrm{ThO}_{2}$ & $0.0 \mathrm{E}+0$ & - & $0.0 \mathrm{E}+0$ & - & $0.0 \mathrm{E}+0$ & $4.92 \mathrm{E}-14$ & $1.11 \mathrm{E}-2$ & $0.0 \mathrm{E}+0$ & $0.0 \mathrm{E}+0$ \\
\hline $\mathrm{HgO}$ & $0.0 \mathrm{E}+0$ & - & $0.0 \mathrm{E}+0$ & - & $0.0 \mathrm{E}+0$ & $3.86 \mathrm{E}-5$ & $3.06 \mathrm{E}-2$ & 7.63E-4 & $0.0 \mathrm{E}+0$ \\
\hline $\mathrm{Th}\left(\mathrm{C}_{2} \mathrm{O}_{4}\right)_{2}$ & $0.0 \mathrm{E}+0$ & - & $0.0 \mathrm{E}+0$ & - & $0.0 \mathrm{E}+0$ & $0.0 \mathrm{E}+0$ & $0.0 \mathrm{E}+0$ & 4.29E-4 & $0.0 \mathrm{E}+0$ \\
\hline Total, kg & $3.45 E+5$ & $0.0 \mathrm{E}+0$ & $5.21 \mathrm{E}+4$ & $0.0 \mathrm{E}+0$ & $3.05 E+6$ & $1.63 E+4$ & $9.39 E+3$ & $3.68 \mathrm{E}+8$ & $1.84 \mathrm{E}+6$ \\
\hline Volume, gal & $8.53 \mathrm{E}+4$ & - & $9.00 \mathrm{E}+3$ & - & $8.0 \mathrm{E}+5$ & $4.14 \mathrm{E}+3$ & $8.63 \mathrm{E}+2$ & $8.94 \mathrm{E}+4$ & $8.16 \mathrm{E}+1$ \\
\hline Enthalpy, cal & $-1.26 \mathrm{E}+12$ & - & $-1.67 \mathrm{E}+11$ & - & - & $-6.07 E+10$ & $-2.84 \mathrm{E}+10$ & $-1.35 E+12$ & $-4.53 E+9$ \\
\hline Density, g/gal & $4.0 \mathrm{E}+3$ & - & $5.79 \mathrm{E}+3$ & - & - & $3.95 \mathrm{E}+3$ & $1.09 \mathrm{E}+4$ & $4.12 \mathrm{E}+3$ & $2.26 \mathrm{E}+4$ \\
\hline Oxalate lon, $\mathrm{kg}$ & $2.69 \mathrm{E}+4$ & - & $0.0 \mathrm{E}+0$ & - & - & $5.47 \mathrm{E}-1$ & $0.0 \mathrm{E}+0$ & $2.61 \mathrm{E}+4$ & $3.62 \mathrm{E}+2$ \\
\hline
\end{tabular}


Table A5-3 Tank 11 HM Dissolution. Balance, $\mathrm{pH}$ w/ NaOH (Case \#3 - Sheet 3 of 4)

\begin{tabular}{|c|c|c|c|c|c|c|c|c|c|c|}
\hline & \begin{tabular}{|c|}
8 \\
\end{tabular} & 9 & 10 & \begin{tabular}{|c|}
11 \\
Diccution
\end{tabular} & & 13a & $13 b$ & 14 & 15 & 16 \\
\hline $\begin{array}{l}\text { Stream } \\
\text { Name }\end{array}$ & $\begin{array}{c}\text { Receipt Tank } \\
\text { Supernate }\end{array}$ & $\begin{array}{l}\text { Evap } \\
\text { Feed }\end{array}$ & $\begin{array}{l}\text { Evap } \\
\text { Conc }\end{array}$ & $\begin{array}{c}\text { Dissolution } \\
\text { Water }\end{array}$ & \begin{tabular}{|c|} 
Dissolved \\
Salt
\end{tabular} & $\begin{array}{l}\text { Solids } \\
\text { Slurry }\end{array}$ & $\begin{array}{l}\text { Receipt } \\
\text { Tank }\end{array}$ & $\begin{array}{l}\text { Washed } \\
\text { Sludge }\end{array}$ & $\begin{array}{l}\text { Decant } \\
\text { Water }\end{array}$ & $\begin{array}{l}\text { Feed } \\
\text { Tank }\end{array}$ \\
\hline Phase & Aqueous & & & Aqueous & Aqueous & Solid & Solid & Slurry & Aqueous & Slurry \\
\hline Temp, C & 30 & - & - & - & - & 30 & 30 & - & - & - \\
\hline $\mathrm{pH}$ & 12.7 & - & & 12 & - & 12.7 & - & - & - & - \\
\hline Flow Units & wtfrac & wtfrac & wtfrac & wtfrac & wtfrac & wtfrac & wtfrac & wtfrac & wtfrac & wtfrac \\
\hline $\mathrm{H}_{2} \mathrm{O}$ & $9.62 \mathrm{E}-1$ & - & - & 9.99E-1 & - & 9.62E-1 & $0.0 \mathrm{E}+0$ & - & $8.08 \mathrm{E}-1$ & - \\
\hline $\mathrm{H}_{2} \mathrm{C}_{2} \mathrm{O}_{4}$ & $0.00 \mathrm{E}+0$ & - & - & $0.0 \mathrm{E}+0$ & - & $0.0 \mathrm{E}+0$ & $0.0 \mathrm{E}+0$ & - & $0.0 \mathrm{E}+0$ & - \\
\hline $\mathrm{HCl}$ & $0.00 \mathrm{E}+0$ & - & - & $0.0 \mathrm{E}+0$ & - & $0.0 \mathrm{E}+0$ & $0.0 \mathrm{E}+0$ & - & $0.0 \mathrm{E}+0$ & - \\
\hline $\mathrm{HNO}_{3}$ & $0.00 \mathrm{E}+0$ & - & - & $0.0 \mathrm{E}+0$ & - & $0.0 \mathrm{E}+0$ & $0.0 \mathrm{E}+0$ & - & $0.0 \mathrm{E}+0$ & - \\
\hline $\mathrm{Na}_{2} \mathrm{CO}_{3}$ & $4.25 E-4$ & - & - & $0.0 E+0$ & - & $4.25 E-4$ & $0.0 E+0$ & - & $1.00 \mathrm{E}-2$ & - \\
\hline $\mathrm{NaCl}$ & $1.34 \mathrm{E}-4$ & - & - & $0.0 \mathrm{E}+0$ & - & $1.34 \mathrm{E}-4$ & $0.0 \mathrm{E}+0$ & - & $2.40 \mathrm{E}-4$ & - \\
\hline $\mathrm{NaNO}_{2}$ & $0.0 \mathrm{E}+0$ & - & - & $7.50 \mathrm{E}-4$ & - & $0.0 \mathrm{E}+0$ & $0.0 \mathrm{E}+0$ & - & $7.63 E-2$ & - \\
\hline $\mathrm{NaNO}_{3}$ & $6.68 \mathrm{E}-4$ & - & - & $0.0 \mathrm{E}+0$ & - & $6.68 \mathrm{E}-4$ & $0.0 \mathrm{E}+0$ & - & 6.97E-2 & - \\
\hline $\mathrm{NaOH}$ & $4.42 \mathrm{E}-3$ & - & - & $3.95 \mathrm{E}-4$ & - & $4.59 \mathrm{E}-3$ & $0.0 \mathrm{E}+0$ & - & 1.76E-2 & - \\
\hline $\mathrm{Na}_{2} \mathrm{SO}_{4}$ & $0.0 \mathrm{E}+0$ & - & - & $0.0 \mathrm{E}+0$ & - & $0.0 \mathrm{E}+0$ & $0.0 \mathrm{E}+0$ & - & 3.03E-3 & - \\
\hline $\mathrm{Na}_{2} \mathrm{C}_{2} \mathrm{O}_{4}$ & $3.06 \mathrm{E}-2$ & $1.0 \mathrm{E}+0$ & $1.0 \mathrm{E}+0$ & $0.0 \mathrm{E}+0$ & $0.0 \mathrm{E}+0$ & $3.06 \mathrm{E}-2$ & 7.67E-1 & 8.76E-2 & 7.66E-3 & $1.0 \mathrm{E}+0$ \\
\hline $\mathrm{Al}(\mathrm{OH})_{3}$ & $0.00 \mathrm{E}+0$ & - & - & $0.0 \mathrm{E}+0$ & - & $0.0 \mathrm{E}+0$ & 1.37E-1 & - & $0.0 \mathrm{E}+0$ & - \\
\hline $\mathrm{AlOOH}$ & $0.00 \mathrm{E}+0$ & - & - & $0.0 \mathrm{E}+0$ & - & $0.0 \mathrm{E}+0$ & $0.0 \mathrm{E}+0$ & - & $0.0 \mathrm{E}+0$ & - \\
\hline $\mathrm{NaAlO}_{2}$ & $0.0 \mathrm{E}+0$ & - & - & $0.0 \mathrm{E}+0$ & - & $6.11 \mathrm{E}-4$ & $0.0 \mathrm{E}+0$ & - & $7.59 \mathrm{E}-3$ & - \\
\hline $\mathrm{CaC}_{2} \mathrm{O}_{4}$ & 7.35E-07 & - & - & $0.0 \mathrm{E}+0$ & - & $7.35 \mathrm{E}-7$ & $0.0 \mathrm{E}+0$ & $5.14 \mathrm{E}-8$ & $3.22 \mathrm{E}-7$ & - \\
\hline $\mathrm{CaCO}_{3}$ & $0.0 \mathrm{E}+0$ & - & - & $0.0 \mathrm{E}+0$ & - & $0.0 \mathrm{E}+0$ & $0.0 \mathrm{E}+0$ & - & $0.0 \mathrm{E}+0$ & - \\
\hline
\end{tabular}


Table A5-3 Tank 11 HM Dissolution. Material Balance, pH Adj. w/ NaOH (Case \#3 - Sheet 4 of 4)

\begin{tabular}{|c|c|c|c|c|c|c|c|c|c|c|}
\hline & 8 & 9 & 10 & 11 & 12 & $13 a$ & $13 b$ & 14 & 15 & 16 \\
\hline Stream Name & \begin{tabular}{|c|} 
Receipt \\
Tank \\
Supernate
\end{tabular} & $\begin{array}{l}\text { Evap } \\
\text { Feed }\end{array}$ & $\begin{array}{l}\text { Evap } \\
\text { Conc }\end{array}$ & \begin{tabular}{|c|} 
Dissolution \\
Water
\end{tabular} & $\begin{array}{l}\text { Dissolved } \\
\text { Salt }\end{array}$ & $\begin{array}{c}\text { Receipt } \\
\text { Tank } \\
\text { Solids }\end{array}$ & $\begin{array}{c}\text { Receipt } \\
\text { Tank } \\
\text { Solids }\end{array}$ & $\begin{array}{l}\text { Washed } \\
\text { Sludge }\end{array}$ & $\begin{array}{l}\text { Decant } \\
\text { Water }\end{array}$ & $\begin{array}{c}\text { Feed } \\
\text { Tank } \\
\text { Sludge }\end{array}$ \\
\hline Flow Units & wtfrac & wtfrac & wtfrac & wtfrac & wtfrac & wtfrac & wtfrac & wtfrac & wtfrac & wtfrac \\
\hline $\mathrm{Ce}_{2} \mathrm{O}_{3}$ & $1.15 \mathrm{E}-4$ & - & - & $0.0 \mathrm{E}+0$ & - & $1.15 \mathrm{E}-4$ & $0.0 \mathrm{E}+0$ & 8.03E-06 & $5.03 E-5$ & - \\
\hline $\mathrm{Ce}_{2}\left(\mathrm{C}_{2} \mathrm{O}_{4}\right)_{3}$ & $0.0 \mathrm{E}+0$ & - & - & $0.0 \mathrm{E}+0$ & - & $0.0 \mathrm{E}+0$ & $0.0 \mathrm{E}+0$ & - & $0.0 \mathrm{E}+0$ & - \\
\hline $\mathrm{Fe}_{2}\left(\mathrm{C}_{2} \mathrm{O}_{4}\right)_{3}$ & $2.37 \mathrm{E}-5$ & - & - & $0.0 \mathrm{E}+0$ & - & $2.37 \mathrm{E}-5$ & $0.0 \mathrm{E}+0$ & $1.66 \mathrm{E}-6$ & $1.04 \mathrm{E}-5$ & - \\
\hline $\mathrm{Fe}(\mathrm{OH})_{3}$ & $0.0 \mathrm{E}+0$ & - & - & $0.0 \mathrm{E}+0$ & - & $0.0 \mathrm{E}+0$ & $6.15 \mathrm{E}-2$ & - & $0.0 \mathrm{E}+0$ & - \\
\hline $\mathrm{K}_{2} \mathrm{C}_{2} \mathrm{O}_{4}$ & $0.0 \mathrm{E}+0$ & - & - & $0.0 \mathrm{E}+0$ & - & $0.0 \mathrm{E}+0$ & $0.0 \mathrm{E}+0$ & $0.00 \mathrm{E}+0$ & $0.0 \mathrm{E}+0$ & - \\
\hline $\mathrm{KOH}$ & $0.0 \mathrm{E}+0$ & - & - & $0.0 \mathrm{E}+0$ & - & $0.0 \mathrm{E}+0$ & $0.0 \mathrm{E}+0$ & - & $0.0 \mathrm{E}+0$ & - \\
\hline $\mathrm{MnC}_{2} \mathrm{O}_{4}$ & $3.56 \mathrm{E}-6$ & - & - & $0.0 \mathrm{E}+0$ & - & $3.56 \mathrm{E}-6$ & $0.0 \mathrm{E}+0$ & $2.49 \mathrm{E}-7$ & $1.56 \mathrm{E}-6$ & - \\
\hline $\mathrm{Mn}(\mathrm{OH})_{2}$ & $0.00 \mathrm{E}+0$ & - & - & $0.0 \mathrm{E}+0$ & - & $0.0 \mathrm{E}+0$ & $1.42 \mathrm{E}-2$ & - & $0.0 \mathrm{E}+0$ & - \\
\hline $\mathrm{NiC}_{2} \mathrm{O}_{4}$ & 8.90E-08 & - & - & $0.0 \mathrm{E}+0$ & - & $8.90 \mathrm{E}-8$ & $0.0 \mathrm{E}+0$ & $6.23 \mathrm{E}-9$ & $3.91 \mathrm{E}-8$ & - \\
\hline $\mathrm{Ni}(\mathrm{OH})_{2}$ & $0.00 \mathrm{E}+0$ & - & - & $0.0 \mathrm{E}+0$ & - & $0.0 \mathrm{E}+0$ & $2.71 \mathrm{E}-3$ & - & $0.0 \mathrm{E}+0$ & - \\
\hline $\mathrm{SiO}_{2}$ & 8.69E-4 & - & - & $0.0 \mathrm{E}+0$ & - & 8.69E-4 & $0.0 \mathrm{E}+0$ & - & $0.0 \mathrm{E}+0$ & - \\
\hline $\mathrm{UO}_{2} \mathrm{C}_{2} \mathrm{O}_{4}$ & $1.21 \mathrm{E}-6$ & - & - & $0.0 \mathrm{E}+0$ & - & $1.21 \mathrm{E}-6$ & $0.0 \mathrm{E}+0$ & $8.47 \mathrm{E}-8$ & $5.31 \mathrm{E}-7$ & - \\
\hline $\mathrm{UO}_{2} \mathrm{OH}_{2}$ & $0.00 \mathrm{E}+0$ & - & - & $0.0 \mathrm{E}+0$ & - & $0.0 \mathrm{E}+0$ & $7.45 \mathrm{E}-3$ & - & $0.0 \mathrm{E}+0$ & - \\
\hline $\mathrm{ThO}_{2}$ & $4.83 E-5$ & - & - & $0.0 \mathrm{E}+0$ & - & $4.83 E-14$ & $2.71 \mathrm{E}-03$ & - & $0.0 \mathrm{E}+0$ & - \\
\hline $\mathrm{HgO}$ & $3.83 E-5$ & - & - & $0.0 \mathrm{E}+0$ & - & $3.83 \mathrm{E}-5$ & 7.07E-03 & - & $0.0 \mathrm{E}+0$ & - \\
\hline $\mathrm{Th}\left(\mathrm{C}_{2} \mathrm{O}_{4}\right)_{2}$ & $0.00 \mathrm{E}+0$ & - & - & $0.0 \mathrm{E}+0$ & - & $0.0 \mathrm{E}+0$ & $0.0 \mathrm{E}+0$ & - & $0.0 \mathrm{E}+0$ & - \\
\hline Total, $\mathrm{kg}$ & $1.93 \mathrm{E}+5$ & $1.23 E+3$ & $1.23 \mathrm{E}+3$ & $8.39 \mathrm{E}+6$ & - & $1.91 \mathrm{E}+5$ & $3.83 E+4$ & $3.69 E+5$ & $3.77 E+5$ & $7.55 \mathrm{E}+3$ \\
\hline Volume, gal & $4.93 \mathrm{E}+4$ & - & \begin{tabular}{|l|}
- \\
\end{tabular} & $2.20 \mathrm{E}+6$ & $3.20 \mathrm{E}+6$ & $4.90 \mathrm{E}+4$ & $8.51 \mathrm{E}+2$ & $5.52 \mathrm{E}+5$ & $1.38 \mathrm{E}+6$ & - \\
\hline Enthalpy, cal & $-7.20 \mathrm{E}+11$ & - & - & - & - & $-7.15 E+11$ & $-9.62 E+10$ & - & - & - \\
\hline Density, g/gal & $3.91 \mathrm{E}+3$ & - & \begin{tabular}{|l|}
- \\
\end{tabular} & $3.82 E+3$ & - & $3.91 \mathrm{E}+3$ & $4.50 \mathrm{E}+4$ & - & - & - \\
\hline Oxalate ion, $\mathrm{kg}$ & $3.87 E+3$ & $8.08 E+2$ & $8.08 \mathrm{E}+2$ & & $0.0 \mathrm{E}+0$ & $3.85 E+3$ & $1.93 E+4$ & $2.12 E+4$ & $1.90 \mathrm{E}+3$ & $4.96 \mathrm{E}+3$ \\
\hline
\end{tabular}


Table A5 - 4 Tank 11 HM Dissolution Material Balance, pH Adj. w/ Supernate (Case \#4 - Sheet 1 of 4)

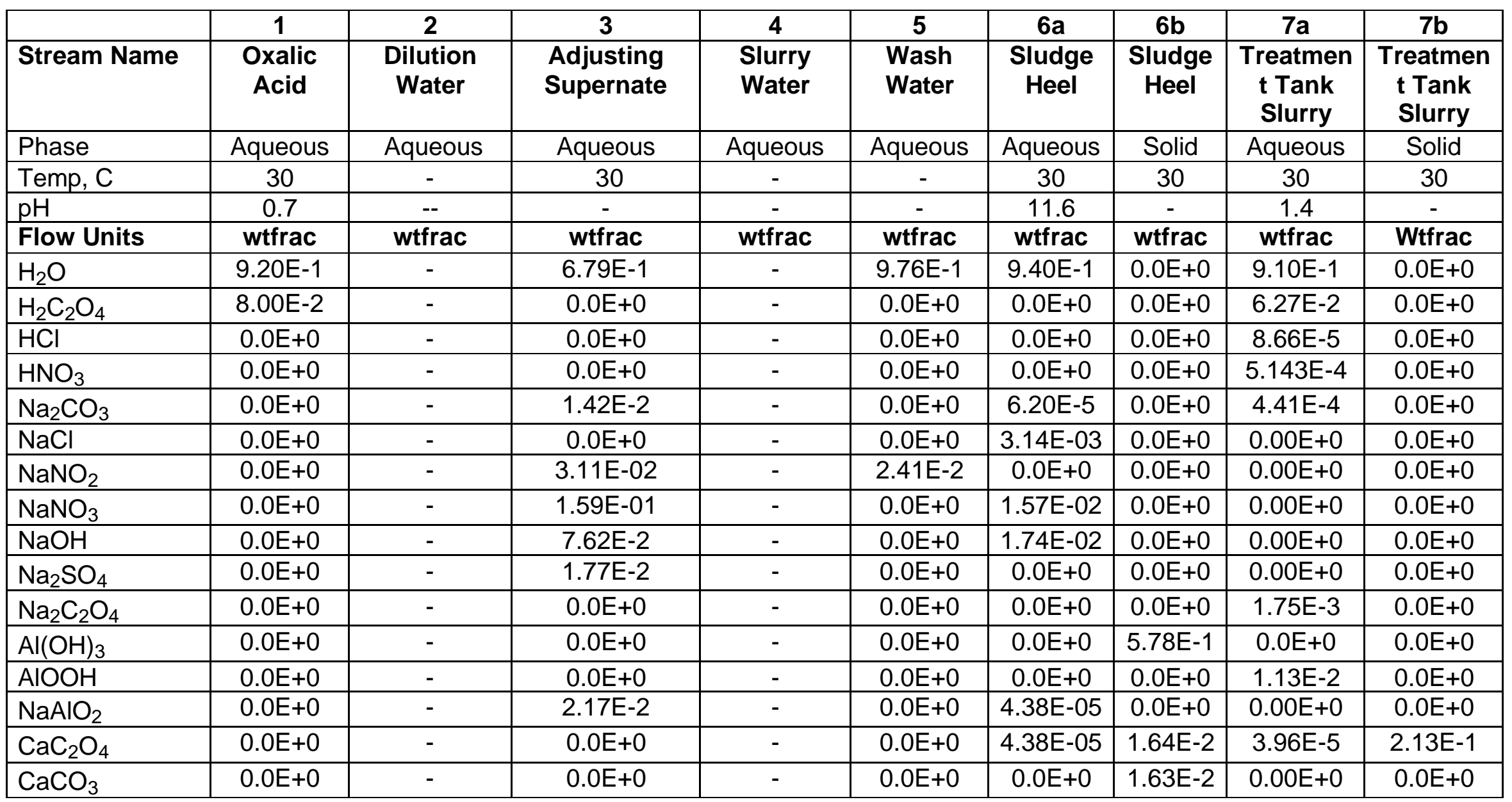


Table A5-4 Tank 11 HM Dissolution. Material Balance, pH Adj. w/ Supernate (Case \#4 - Sheet 2 of 4)

\begin{tabular}{|c|c|c|c|c|c|c|c|c|c|}
\hline & 1 & 2 & 3 & 4 & 5 & $6 a$ & $6 b$ & $7 a$ & $7 b$ \\
\hline Stream Name & $\begin{array}{l}\text { Oxalic } \\
\text { Acid }\end{array}$ & $\begin{array}{c}\text { Dilution } \\
\text { Water }\end{array}$ & Supernate & $\begin{array}{l}\text { Slurry } \\
\text { Water }\end{array}$ & $\begin{array}{l}\text { Wash } \\
\text { Water }\end{array}$ & $\begin{array}{c}\text { Sludge } \\
\text { Heel }\end{array}$ & $\begin{array}{c}\text { Sludge } \\
\text { Heel }\end{array}$ & $\begin{array}{c}\text { Treatmen } \\
\text { t Tank } \\
\text { Slurry }\end{array}$ & $\begin{array}{c}\text { Treatmen } \\
\text { t Tank } \\
\text { Slurry }\end{array}$ \\
\hline Flow Units & wtfrac & wtfrac & wtfrac & wtfrac & wtfrac & wtfrac & wtfrac & wtfrac & Wtfrac \\
\hline $\mathrm{Ca}(\mathrm{OH})_{2}$ & $0.0 \mathrm{E}+0$ & - & $0.0 \mathrm{E}+0$ & - & $0.0 \mathrm{E}+0$ & 4.33E-5 & $0.0 \mathrm{E}+0$ & $0.0 \mathrm{E}+0$ & $0.0 \mathrm{E}+0$ \\
\hline $\mathrm{Ce}_{2} \mathrm{O}_{3}$ & $0.0 \mathrm{E}+0$ & - & $0.0 \mathrm{E}+0$ & - & $0.0 \mathrm{E}+0$ & $2.69 \mathrm{E}-3$ & $0.0 \mathrm{E}+0$ & $0.0 \mathrm{E}+0$ & $0.0 \mathrm{E}+0$ \\
\hline $\mathrm{Ce}_{2}\left(\mathrm{C}_{2} \mathrm{O}_{4}\right)_{3}$ & $0.0 \mathrm{E}+0$ & - & $0.0 \mathrm{E}+0$ & - & $0.0 \mathrm{E}+0$ & $0.0 \mathrm{E}+0$ & $0.0 \mathrm{E}+0$ & $6.07 \mathrm{E}-5$ & $2.44 \mathrm{E}-2$ \\
\hline $\mathrm{Fe}_{2}\left(\mathrm{C}_{2} \mathrm{O}_{4}\right)_{3}$ & $0.0 \mathrm{E}+0$ & - & $0.0 \mathrm{E}+0$ & - & $0.0 \mathrm{E}+0$ & $0.0 \mathrm{E}+0$ & $0.0 \mathrm{E}+0$ & $1.11 \mathrm{E}-2$ & $0.0 \mathrm{E}+0$ \\
\hline $\mathrm{Fe}(\mathrm{OH})_{3}$ & $0.0 \mathrm{E}+0$ & - & $0.0 \mathrm{E}+0$ & - & $0.0 \mathrm{E}+0$ & $9.59 \mathrm{E}-7$ & $2.49 \mathrm{E}-1$ & $0.00 \mathrm{E}+0$ & $0.0 \mathrm{E}+0$ \\
\hline $\mathrm{K}_{2} \mathrm{C}_{2} \mathrm{O}_{4}$ & $0.0 \mathrm{E}+0$ & - & $0.0 \mathrm{E}+0$ & - & $0.0 \mathrm{E}+0$ & $0.0 \mathrm{E}+0$ & $0.0 \mathrm{E}+0$ & $0.00 \mathrm{E}+0$ & $0.0 \mathrm{E}+0$ \\
\hline $\mathrm{KOH}$ & $0.0 \mathrm{E}+0$ & - & $7.46 \mathrm{E}-4$ & - & $0.0 \mathrm{E}+0$ & $0.0 \mathrm{E}+0$ & $0.0 \mathrm{E}+0$ & $0.00 \mathrm{E}+0$ & $0.0 \mathrm{E}+0$ \\
\hline $\mathrm{MnC}_{2} \mathrm{O}_{4}$ & $0.0 \mathrm{E}+0$ & - & $0.0 \mathrm{E}+0$ & - & $0.0 \mathrm{E}+0$ & $0.0 \mathrm{E}+0$ & $0.0 \mathrm{E}+0$ & $2.79 \mathrm{E}-4$ & $4.84 \mathrm{E}-1$ \\
\hline $\mathrm{MnOH}_{2}$ & $0.0 \mathrm{E}+0$ & - & $0.0 \mathrm{E}+0$ & - & $0.0 \mathrm{E}+0$ & $1.03 \mathrm{E}-7$ & $5.76 \mathrm{E}-2$ & $0.00 \mathrm{E}+0$ & $0.0 \mathrm{E}+0$ \\
\hline $\mathrm{NiC}_{2} \mathrm{O}_{4}$ & $0.0 \mathrm{E}+0$ & - & $0.0 \mathrm{E}+0$ & - & $0.0 \mathrm{E}+0$ & $0.0 \mathrm{E}+0$ & $0.0 \mathrm{E}+0$ & $5.11 \mathrm{E}-5$ & $9.10 \mathrm{E}-2$ \\
\hline $\mathrm{Ni}(\mathrm{OH})_{2}$ & $0.0 \mathrm{E}+0$ & - & $0.0 \mathrm{E}+0$ & - & $0.0 \mathrm{E}+0$ & $4.53 \mathrm{E}-9$ & $1.10 \mathrm{E}-2$ & $0.00 \mathrm{E}+0$ & $0.0 \mathrm{E}+0$ \\
\hline $\mathrm{SiO}_{2}$ & $0.0 \mathrm{E}+0$ & - & $0.0 \mathrm{E}+0$ & - & $0.0 \mathrm{E}+0$ & $2.04 \mathrm{E}-2$ & $0.0 \mathrm{E}+0$ & $1.02 \mathrm{E}-4$ & $1.88 \mathrm{E}-1$ \\
\hline $\mathrm{UO}_{2} \mathrm{C}_{2} \mathrm{O}_{4}$ & $0.0 \mathrm{E}+0$ & - & $0.0 \mathrm{E}+0$ & - & $0.0 \mathrm{E}+0$ & $0.0 \mathrm{E}+0$ & $0.0 \mathrm{E}+0$ & 8.99E-4 & $0.0 \mathrm{E}+0$ \\
\hline $\mathrm{UO}_{2} \mathrm{OH}_{2}$ & $0.0 \mathrm{E}+0$ & - & $0.0 \mathrm{E}+0$ & - & $0.0 \mathrm{E}+0$ & $2.69 \mathrm{E}-7$ & $3.01 \mathrm{E}-2$ & $0.00 \mathrm{E}+0$ & $0.0 \mathrm{E}+0$ \\
\hline $\mathrm{ThO}_{2}$ & $0.0 \mathrm{E}+0$ & - & $0.0 \mathrm{E}+0$ & - & $0.0 \mathrm{E}+0$ & $4.93 \mathrm{E}-14$ & $1.1 \mathrm{E}-2$ & $0.00 \mathrm{E}+0$ & $0.0 \mathrm{E}+0$ \\
\hline $\mathrm{HgO}$ & $0.0 \mathrm{E}+0$ & - & $0.0 \mathrm{E}+0$ & - & $0.0 \mathrm{E}+0$ & $3.86 \mathrm{E}-5$ & $3.01 \mathrm{E}-2$ & $7.63 \mathrm{E}-4$ & $0.0 \mathrm{E}+0$ \\
\hline $\mathrm{Th}\left(\mathrm{C}_{2} \mathrm{O}_{4}\right)_{2}$ & $0.0 \mathrm{E}+0$ & - & $0.0 \mathrm{E}+0$ & - & $0.0 \mathrm{E}+0$ & $0.0 \mathrm{E}+0$ & $0.0 \mathrm{E}+0$ & $4.29 \mathrm{E}-4$ & $0.0 \mathrm{E}+0$ \\
\hline Total , kg & $3.45 \mathrm{E}+5$ & $0.0 \mathrm{E}+0$ & $3.09 \mathrm{E}+2$ & $0.0 \mathrm{E}+0$ & $3.05 E+3$ & $1.72 \mathrm{E}+1$ & $9.39 \mathrm{E}+0$ & $3.68 \mathrm{E}+2$ & $1.84 \mathrm{E}+0$ \\
\hline Volume, gal & $8.53 \mathrm{E}+4$ & - & $6.55 \mathrm{E}+4$ & - & $8.0 \mathrm{E}+5$ & $4.14 \mathrm{E}+3$ & $8.63 \mathrm{E}+2$ & $8.94 \mathrm{E}+4$ & $8.16 \mathrm{E}+1$ \\
\hline Enthalpy, cal & $-1.24 \mathrm{E}+12$ & - & $-9.80 \mathrm{E}+11$ & - & - & $-6.1 E+10$ & $-2.8 E+10$ & $-1.35 \mathrm{E} 12$ & $-4.53 E+9$ \\
\hline Density, g/gal & $4.04 \mathrm{E}+3$ & - & $4.72 \mathrm{E}+3$ & - & - & $3.95 E+3$ & $1.09 \mathrm{E}+4$ & $4.12 \mathrm{E}+3$ & $2.26 \mathrm{E}+4$ \\
\hline Oxalate ion, $\mathrm{kg}$ & $2.69 E+4$ & & $0.0 \mathrm{E}+0$ & & & $5.75 \mathrm{E}-1$ & $1.06 \mathrm{E}+02$ & $2.61 \mathrm{E}+4$ & $9.42 \mathrm{E}+2$ \\
\hline
\end{tabular}


Table A5-4 Tank 11HM Dissolution. Material Balance, pH Adjusted with Supernate (Case \#4 - Sheet 3 of 4)

\begin{tabular}{|c|c|c|c|c|c|c|c|c|c|c|}
\hline & 8 & 9 & 10 & 11 & 12 & $13 a$ & $13 b$ & 14 & 15 & 16 \\
\hline Stream Name & $\begin{array}{c}\text { Receipt } \\
\text { Tank } \\
\text { Supernate }\end{array}$ & $\begin{array}{l}\text { Evap } \\
\text { Feed }\end{array}$ & $\begin{array}{l}\text { Evap } \\
\text { Conc }\end{array}$ & $\begin{array}{c}\text { Dissolution } \\
\text { Water }\end{array}$ & $\begin{array}{l}\text { Dissolved } \\
\text { Salt }\end{array}$ & $\begin{array}{c}\text { Receipt } \\
\text { Tank } \\
\text { Solids }\end{array}$ & $\begin{array}{c}\text { Receipt } \\
\text { Tank } \\
\text { Solids }\end{array}$ & $\begin{array}{l}\text { Washed } \\
\text { Sludge }\end{array}$ & $\begin{array}{l}\text { Decant } \\
\text { Water }\end{array}$ & \begin{tabular}{|c|} 
Feed Tank \\
Sludge
\end{tabular} \\
\hline Phase & Aqueous & Aqueous & Aqueous & Aqueous & Aqueous & Aqueous & Solid & Slurry & Aqueous & Slurry \\
\hline Temp, ${ }^{\circ} \mathrm{C}$ & 30 & - & - & - & - & 30 & 30 & - & - & - \\
\hline $\mathrm{pH}$ & 12.8 & - & - & 12.0 & - & 12.8 & & - & - & - \\
\hline Flow Units & wtfrac & wtfrac & wtfrac & wtfrac & wtfrac & wtfrac & wtfrac & wtfrac & wtfrac & wtfrac \\
\hline $\mathrm{H}_{2} \mathrm{O}$ & $8.78 \mathrm{E}-1$ & - & - & $9.99 \mathrm{E}-1$ & - & $8.71 \mathrm{E}-1$ & $0.0 \mathrm{E}+0$ & - & $7.63 \mathrm{E}-2$ & - \\
\hline $\mathrm{H}_{2} \mathrm{C}_{2} \mathrm{O}_{4}$ & $0.0 \mathrm{E}+0$ & - & - & $0.0 \mathrm{E}+0$ & - & $0.0 \mathrm{E}+0$ & $0.0 \mathrm{E}+0$ & - & $0.0 \mathrm{E}+0$ & - \\
\hline $\mathrm{HCl}$ & $0.0 \mathrm{E}+0$ & - & - & $0.0 \mathrm{E}+0$ & - & $0.0 \mathrm{E}+0$ & $0.0 \mathrm{E}+0$ & - & $0.0 \mathrm{E}+0$ & - \\
\hline $\mathrm{HNO}_{3}$ & $0.0 \mathrm{E}+0$ & - & - & $0.0 \mathrm{E}+0$ & - & $0.0 \mathrm{E}+0$ & $0.0 \mathrm{E}+0$ & - & $0.0 \mathrm{E}+0$ & - \\
\hline $\mathrm{Na}_{2} \mathrm{CO}_{3}$ & $7.26 \mathrm{E}-3$ & - & - & $0.0 \mathrm{E}+0$ & - & $7.23 \mathrm{E}-3$ & $0.0 \mathrm{E}+0$ & - & $1.00 \mathrm{E}-2$ & - \\
\hline $\mathrm{NaCl}$ & $8.18 \mathrm{E}-5$ & - & - & $0.0 \mathrm{E}+0$ & - & $8.15 E-5$ & $0.0 \mathrm{E}+0$ & - & $2.40 \mathrm{E}-4$ & - \\
\hline $\mathrm{NaNO}_{2}$ & $1.53 \mathrm{E}-2$ & - & - & $7.5 \mathrm{E}-4$ & - & $1.53 \mathrm{E}-2$ & $0.0 \mathrm{E}+0$ & - & $7.66 \mathrm{E}-2$ & - \\
\hline $\mathrm{NaNO}_{3}$ & 7.89E-2 & - & - & $0.0 \mathrm{E}+0$ & - & $7.85 \mathrm{E}-2$ & $0.0 \mathrm{E}+0$ & - & $6.790 \mathrm{E}-2$ & - \\
\hline $\mathrm{NaOH}$ & $4.13 E-3$ & - & - & $3.95 \mathrm{E}-4$ & - & 1.16E-2 & $0.0 \mathrm{E}+0$ & - & 1.76E-2 & - \\
\hline $\mathrm{Na}_{2} \mathrm{SO}_{4}$ & 8.74E-3 & - & - & $0.0 \mathrm{E}+0$ & - & 8.70E-3 & $0.0 \mathrm{E}+0$ & - & $3.02 \mathrm{E}-3$ & - \\
\hline $\mathrm{Na}_{2} \mathrm{C}_{2} \mathrm{O}_{4}$ & $5.44 \mathrm{E}-3$ & $1.0 \mathrm{E}+0$ & $1.0 \mathrm{E}+0$ & $0.0 \mathrm{E}+0$ & $0.0 \mathrm{E}+0$ & $5.42 \mathrm{E}-3$ & $7.11 \mathrm{E}-1$ & 9.63E-2 & 7.66E-3 & $1.0 \mathrm{E}+0$ \\
\hline $\mathrm{Al}(\mathrm{OH})_{3}$ & $0.0 \mathrm{E}+0$ & - & - & $0.0 \mathrm{E}+0$ & - & $0.0 \mathrm{E}+0$ & $2.18 \mathrm{E}-1$ & - & $0.0 \mathrm{E}+0$ & - \\
\hline $\mathrm{AlOOH}$ & $0.0 \mathrm{E}+0$ & - & - & $0.0 \mathrm{E}+0$ & - & $0.0 \mathrm{E}+0$ & $0.0 \mathrm{E}+0$ & - & $0.0 \mathrm{E}+0$ & - \\
\hline $\mathrm{NaAlO}_{2}$ & $7.53 \mathrm{E}-4$ & - & - & $0.0 \mathrm{E}+0$ & - & $7.50 \mathrm{E}-4$ & $0.0 \mathrm{E}+0$ & - & 7.59E-3 & - \\
\hline $\mathrm{CaC}_{2} \mathrm{O}_{4}$ & $2.24 \mathrm{E}-6$ & - & - & $0.0 \mathrm{E}+0$ & - & $2.23 E-6$ & $6.73 E-3$ & $9.49 \mathrm{E}-4$ & $1.33 \mathrm{E}-6$ & - \\
\hline $\mathrm{CaCO}_{3}$ & $0.0 \mathrm{E}+0$ & - & - & $0.0 \mathrm{E}+0$ & - & $0.0 \mathrm{E}+0$ & $0.0 \mathrm{E}+0$ & - & $0.0 \mathrm{E}+0$ & - \\
\hline
\end{tabular}


Table A5-4 Tank 11 HM Dissolution Material Balance, pH Adjusted with Supernate (Case \#4 - Sheet 4 of 4)

\begin{tabular}{|c|c|c|c|c|c|c|c|c|c|c|}
\hline & 8 & 9 & 10 & 11 & 12 & $13 a$ & $13 b$ & 14 & 15 & 16 \\
\hline Stream Name & \begin{tabular}{|c|} 
Receipt \\
Tank \\
Supernate
\end{tabular} & $\begin{array}{l}\text { Evap } \\
\text { Feed }\end{array}$ & $\begin{array}{l}\text { Evap } \\
\text { Conc }\end{array}$ & $\begin{array}{c}\text { Dissolutio } \\
\text { n. Water }\end{array}$ & \begin{tabular}{|c|} 
Dissolved \\
Salt
\end{tabular} & $\begin{array}{c}\text { Receipt } \\
\text { Tank } \\
\text { Solids }\end{array}$ & $\begin{array}{c}\text { Receipt } \\
\text { Tank } \\
\text { Solids }\end{array}$ & $\begin{array}{l}\text { Washed } \\
\text { Sludge }\end{array}$ & $\begin{array}{l}\text { Decant } \\
\text { Water }\end{array}$ & $\begin{array}{c}\text { Feed } \\
\text { Tank } \\
\text { Sludge }\end{array}$ \\
\hline Flow Units & Wtfrac & wtfrac & wtfrac & wtfrac & wtfrac & Wtfrac & wtfrac & wtfrac & wtfrac & wtfrac \\
\hline $\mathrm{Ca}(\mathrm{OH})_{2}$ & $0.0 \mathrm{E}+0$ & - & - & $0.0 \mathrm{E}+0$ & - & $0.0 \mathrm{E}+0$ & $0.0 \mathrm{E}+0$ & - & $0.0 \mathrm{E}+0$ & - \\
\hline $\mathrm{Ce}_{15} \mathrm{O}_{3}$ & $7.03 E-5$ & - & - & $0.0 \mathrm{E}+0$ & - & $6.99 \mathrm{E}-5$ & $0.0 \mathrm{E}+0$ & $6.66 \mathrm{E}-6$ & $4.17 \mathrm{E}-5$ & - \\
\hline $\mathrm{Ce}_{2}\left(\mathrm{C}_{2} \mathrm{O}_{4}\right)_{15}$ & $0.0 \mathrm{E}+0$ & - & - & $0.0 \mathrm{E}+0$ & - & $0.0 \mathrm{E}+0$ & $0.0 \mathrm{E}+0$ & - & $0.0 \mathrm{E}+0$ & - \\
\hline $\mathrm{Fe}_{2}\left(\mathrm{C}_{2} \mathrm{O}_{4}\right)_{3}$ & $3.09 \mathrm{E}-5$ & - & - & $0.0 \mathrm{E}+0$ & - & $3.08 \mathrm{E}-5$ & $0.0 \mathrm{E}+0$ & $2.93 \mathrm{E}-6$ & $1.84 \mathrm{E}-5$ & - \\
\hline $\mathrm{Fe}(\mathrm{OH})_{3}$ & $0.0 \mathrm{E}+0$ & - & - & $0.0 \mathrm{E}+0$ & - & $0.0 \mathrm{E}+0$ & $4.47 \mathrm{E}-2$ & - & $0.0 \mathrm{E}+0$ & - \\
\hline $\mathrm{K}_{2} \mathrm{C}_{2} \mathrm{O}_{4}$ & $5.44 \mathrm{E}-4$ & - & - & $0.0 \mathrm{E}+0$ & - & $5.42 \mathrm{E}-4$ & $0.0 \mathrm{E}+0$ & $5.16 \mathrm{E}-5$ & $3.23 \mathrm{E}-4$ & - \\
\hline $\mathrm{KOH}$ & $0.0 \mathrm{E}+0$ & - & - & $0.0 \mathrm{E}+0$ & - & $0.0 \mathrm{E}+0$ & $0.0 \mathrm{E}+0$ & - & $0.0 \mathrm{E}+0$ & - \\
\hline $\mathrm{MnC}_{2} \mathrm{O}_{4}$ & $1.92 \mathrm{E}-7$ & - & - & $0.0 \mathrm{E}+0$ & - & $1.91 \mathrm{E}-7$ & $0.0 \mathrm{E}+0$ & $1.82 \mathrm{E}-8$ & $1.14 \mathrm{E}-7$ & - \\
\hline $\mathrm{MnOH}_{2}$ & $0.0 \mathrm{E}+0$ & - & - & $0.0 \mathrm{E}+0$ & - & $0.0 \mathrm{E}+0$ & 1.04E-2 & - & $0.0 \mathrm{E}+0$ & - \\
\hline $\mathrm{NiC}_{2} \mathrm{O}_{4}$ & $1.15 \mathrm{E}-7$ & - & - & $0.0 \mathrm{E}+0$ & - & $1.15 \mathrm{E}-7$ & $0.0 \mathrm{E}+0$ & $1.09 \mathrm{E}-8$ & $6.84 \mathrm{E}-8$ & - \\
\hline $\mathrm{Ni}(\mathrm{OH})_{2}$ & $0.0 \mathrm{E}+0$ & - & - & $0.0 \mathrm{E}+0$ & - & $0.0 \mathrm{E}+0$ & 1.97E-3 & - & $0.0 \mathrm{E}+0$ & - \\
\hline $\mathrm{SiO}_{2}$ & $5.32 \mathrm{E}-4$ & - & - & $0.0 \mathrm{E}+0$ & - & $5.29 \mathrm{E}-4$ & $0.0 \mathrm{E}+0$ & - & $0.0 \mathrm{E}+0$ & - \\
\hline $\mathrm{UO}_{2} \mathrm{C}_{2} \mathrm{O}_{4}$ & $5.30 \mathrm{E}-4$ & - & - & $0.0 \mathrm{E}+0$ & - & $5.28 \mathrm{E}-4$ & $0.0 \mathrm{E}+0$ & $5.02 E-5$ & $3.15 \mathrm{E}-4$ & - \\
\hline $\mathrm{UO}_{2} \mathrm{OH}_{2}$ & $0.0 \mathrm{E}+0$ & - & - & $0.0 \mathrm{E}+0$ & - & $0.0 \mathrm{E}+0$ & $0.0 \mathrm{E}+0$ & - & $0.0 \mathrm{E}+0$ & - \\
\hline $\mathrm{ThO}_{2}$ & $3.71 \mathrm{E}-14$ & - & - & $0.0 \mathrm{E}+0$ & - & $3.7 \mathrm{E}-14$ & $1.97 \mathrm{E}-3$ & - & $0.0 \mathrm{E}+0$ & - \\
\hline $\mathrm{HgO}$ & $3.08 \mathrm{E}-5$ & - & - & $0.0 \mathrm{E}+0$ & - & $3.06 \mathrm{E}-5$ & $5.06 \mathrm{E}-3$ & - & $0.0 \mathrm{E}+0$ & - \\
\hline $\mathrm{Th}\left(\mathrm{C}_{2} \mathrm{O}_{4}\right)_{2}$ & $0.0 \mathrm{E}+0$ & - & - & $0.0 \mathrm{E}+0$ & - & $0.0 \mathrm{E}+0$ & $0.0 \mathrm{E}+0$ & - & $0.0 \mathrm{E}+0$ & - \\
\hline Total, kg & $3.67 \mathrm{E}+5$ & $9.90 \mathrm{E}+2$ & $9.90 \mathrm{E}+2$ & $8.39 \mathrm{E}+6$ & - & $2.60 \mathrm{E}+5$ & $5.21 \mathrm{E}+4$ & $3.69 \mathrm{E}+5$ & $3.77 \mathrm{E}+8$ & $3.90 \mathrm{E}+3$ \\
\hline Volume, gal & $8.93 \mathrm{E}+4$ & - & - & $2.20 \mathrm{E}+6$ & $3.2 \mathrm{E}+6$ & $6.33 \mathrm{E}+4$ & $1.52 \mathrm{E}+3$ & $5.52 \mathrm{E}+5$ & $1.38 \mathrm{E}+6$ & - \\
\hline Enthalpy, cal & $-1.30 \mathrm{E}+12$ & - & - & - & - & $-9.1 E+11$ & $-1.4 \mathrm{E}+11$ & - & - & - \\
\hline Density, g/gal & $4.11 \mathrm{E}+3$ & - & - & $3.82 E+3$ & - & $4.11 \mathrm{E}+3$ & $3.43 E+4$ & - & - & - \\
\hline Oxalate ion, $\mathrm{kg}$ & $1.48 \mathrm{E}+3$ & $6.5 \mathrm{E}+2$ & $6.5 \mathrm{E}+2$ & - & $0.0 \mathrm{E}+0$ & $1.04 \mathrm{E}+3$ & $2.46 E+4$ & $2.33 E+4$ & $2.00 E+3$ & $2.56 \mathrm{E}+3$ \\
\hline
\end{tabular}




\section{APPENDIX 6 HISTORICAL EXPERIENCE OF CLEANING TANK 16}

In order to ensure flowsheet and model validation, historical data from oxalic acid cleaning of Tank 16 is compared to a model of the acid cleaning process. Table A6-1 shows the sequence of events with data needed to create the model inputs for streams 1, 2, and 3. Stream 6 is defined by the data shown in Table A6-2. Table A6-3 shows the output for stream 7 in contrast with the sample data obtained in Tank 16 after each wash cycle. Sample data was not available to compare the results of stream 13 or stream 8 .

Table A6-3 highlights one important aspect about using equilibrium models to forecast dissolution results; that is, the model forecasts a complete dissolution on the first wash cycle, but significant amount of solids still existed as demonstrated in the measured total metals content. The relatively constant iron concentration implies dissolution of iron in wash cycles after the first. The model shows the total concentration of all metals as decreasing by dilution effects only in each subsequent batch. The measured aluminum and manganese appear to follow a similar trend, but the actual values and measured values differ considerably, perhaps because some solids are dissolving, or the analytical/sample variance in measured values is very high. The model very closely tracks the total soluble oxalate concentration. Although the information presented on solubility test solutions in Section 7.2 shows that OLI ESP ${ }^{\odot}$ has a predilection to under-predict solubility, the forecasted concentrations are adequate when compared to field measured data. This is consistent with the overall determination of the Chapter 4 validation. 
Table A6-1 Sequence of Events for Tank 16 Acid Cleaning (Sheet 1 of 2)

\section{Acid Wash Cycle 1}

- 3,500 gallon heel to be treated with oxalic acid

- $\quad$ Sprayed about 37,000 gal of water through Riser 1

- Added 12,611 gallons of $4 \mathrm{wt} \%$ oxalic acid directly to heel

- Flushed with 4,500 gallons of water $90^{\circ} \mathrm{C}-41,596$ gallons total water added to tank

- $\quad$ Slurry pumps started when pump volutes became submerged

- $\quad$ Agitated for 2 days

- $\quad 22,937$ gallons seal water from pumps added to tanks - total water added.

- Transferred to Tank 21 about 4,503 gallons $50 \%$ wt $\% \mathrm{NaOH}$ added to HPT-4 to achieve $\mathrm{pH}>12$

- $\quad 3,500$ gallon heel remained after transfer 


\section{Table A6-1 Sequence of Events for Tank 16 Acid Cleaning}

(Sheet 2 of 2)

\begin{tabular}{|c|c|}
\hline \multicolumn{2}{|r|}{ Acid Wash Cycle 2} \\
\hline • & Sprayed 41,000 gal of water through Riser 1 \\
\hline • & $\begin{array}{l}\text { Sprayed } 1,800-2,000 \text { gallons of } 4 \text { wt } \% \text { oxalic acid through each of } 5 \\
\text { spray risers }-9,865 \text { gal total }\end{array}$ \\
\hline • & $\begin{array}{l}\text { Flushed with } 5,400 \text { gallons of water }-46,477 \text { gallons total water added } \\
\text { to tank }\end{array}$ \\
\hline • & Slurry pumps started when volutes became submerged \\
\hline • & Agitate for 40 hours \\
\hline • & $\begin{array}{l}27,220 \text { gallons seal water from pumps added to tanks - total water } \\
\text { added }\end{array}$ \\
\hline • & $\begin{array}{l}\text { Transfer to Tank } 21,2473 \text { gallons of } 50 \mathrm{wt} \% \mathrm{NaOH} \text { added to HPT-4 to } \\
\text { achieve } \mathrm{pH}>12\end{array}$ \\
\hline$\bullet$ & 2,800 gallon heel remained after transfer \\
\hline \multicolumn{2}{|r|}{ Acid Wash Cycle 3} \\
\hline & $\begin{array}{l}\text { rayed } 9,000-12,000 \text { gallons of } 4 \mathrm{wt} \% \text { oxalic acid at } 90^{\circ} \mathrm{C} \text { through each of } \\
\text { pray risers }-50,545 \text { gallons total } \\
\text { shed with } 5,797 \text { gallons of water } \\
\text { Irry pumps started when volutes became submerged } \\
\text { tated for } 48 \text { hours } \\
220 \text { gallons seal water from pumps added to tanks - total water added } \\
\text { Insferred to Tank } 22,50 \mathrm{wt} \% \mathrm{NaOH} \text { added to HPT-4 to achieve } \mathrm{pH} 12> \\
3,675 \text { gallon heel remained after transfer }\end{array}$ \\
\hline \multicolumn{2}{|r|}{ After Wash Cycle 3 } \\
\hline & $\begin{array}{l}\text { ut } 100 \text { gallons of material remained in a pile } \\
\text { orial was sampled but data not reported completely - radionuclides } \\
\left.\mathrm{O}_{3} \mathrm{H}_{2} \mathrm{O}\right) \text { ", but not quantified }\end{array}$ \\
\hline
\end{tabular}


Table A6-2 Tank 16 Sludge Composition

\begin{tabular}{|c|c|}
\hline Constituent & $\mathbf{w t} \%$ \\
\hline $\mathrm{AlO}^{-2}$ & 16 \\
\hline $\mathrm{Fe}^{+3}$ & 40 \\
\hline $\mathrm{MnO}_{2}$ & 16 \\
\hline $\mathrm{Na}^{+}$ & 20 \\
\hline $\mathrm{SO}_{4}{ }^{-2}$ & 1.1 \\
\hline $\mathrm{Si}^{+4}$ & 2 \\
\hline $\mathrm{Ba}^{+2}$ & 1 \\
\hline $\mathrm{Ca}^{+2}$ & 1 \\
\hline $\mathrm{Ce}^{+4}$ & 1 \\
\hline $\mathrm{Hg}^{+2}$ & 2.5 \\
\hline $\mathrm{UO}_{2}{ }^{+2}$ & 0.4 \\
\hline $\mathrm{Total}^{+2}$ & 100 \\
\hline
\end{tabular}


Table A6-3 Comparison of Tank 16 Forecast and Measured Dissolution Results

\begin{tabular}{|c|c|c|c|c|c|c|c|c|c|c|c|c|c|}
\hline \multirow[b]{2}{*}{ Step } & \multirow[b]{2}{*}{$\begin{array}{c}\text { density } \\
\text { (kg/L) }\end{array}$} & \multirow{2}{*}{$\begin{array}{l}\text { Vol \% } \\
\text { solids }\end{array}$} & \multicolumn{8}{|c|}{ Concentration in Aqueous Phase } & \multicolumn{3}{|c|}{ Concentration in Slurry } \\
\hline & & & $\mathrm{NO}_{3}$ & $\mathrm{NO}_{2}$ & $\mathrm{OH}$ & $\mathrm{C}_{2} \mathrm{O}_{4}$ & $\mathrm{Fe}$ & Mn & Al & $\mathbf{H}$ & $\mathrm{Fe}$ & Mn & Al \\
\hline \multicolumn{3}{|c|}{ Measured } & \multicolumn{11}{|c|}{ (M) } \\
\hline Acid Wash 1 & $1.0 \mathrm{E}+0$ & $<0.5$ & $2.5 \mathrm{E}-2$ & NM & NM & $5.1 \mathrm{E}-2$ & $4.0 \mathrm{E}-3$ & NM & $2.1 \mathrm{E}-2$ & $2.9 \mathrm{E}-2$ & $1.7 \mathrm{E}-2$ & $9.9 \mathrm{E}-3$ & $4.0 \mathrm{E}-3$ \\
\hline Acid Wash 2 & $1.0 \mathrm{E}+0$ & $6.0 \mathrm{E}-1$ & $6.0 \mathrm{E}-3$ & NM & NM & $4.8 \mathrm{E}-2$ & $5.7 E-3$ & 4.4E-4 & 3.3E-3 & $5.4 \mathrm{E}-2$ & $1.1 \mathrm{E}-2$ & $6.5 \mathrm{E}-4$ & $7.2 \mathrm{E}-3$ \\
\hline Acid Wash 3 & $1.0 \mathrm{E}+0$ & $<0.5$ & $2.8 \mathrm{E}-3$ & NM & NM & $3.1 \mathrm{E}-1$ & $4.0 \mathrm{E}-2$ & $7.4 \mathrm{E}-5$ & $4.6 \mathrm{E}-3$ & $4.9 \mathrm{E}-1$ & 7.6E-2 & $7.0 \mathrm{E}-4$ & $5.9 \mathrm{E}-3$ \\
\hline Acid Wash 2 & - & - & - & - & - & $5.8 \mathrm{E}-2$ & $5.1 \mathrm{E}-4$ & $1.3 \mathrm{E}-4$ & $1.4 \mathrm{E}-3$ & $1.1 \mathrm{E}-1$ & $5.1 \mathrm{E}-4$ & $1.3 \mathrm{E}-4$ & $1.4 \mathrm{E}-3$ \\
\hline Acid Wash 3 & - & - & - & - & - & $2.9 \mathrm{E}-1$ & $2.3 E-5$ & $6.0 \mathrm{E}-6$ & $6.4 \mathrm{E}-5$ & $5.7 \mathrm{E}-1$ & $2.3 \mathrm{E}-5$ & 6.0E-6 & $6.4 \mathrm{E}-5$ \\
\hline
\end{tabular}

